\title{
Assessment and recovery of tax incentives in the EC and the WTO: A view on state aids, trade subsidies and direct taxation
}

Citation for published version (APA):

Luja, R. H. C. (2003). Assessment and recovery of tax incentives in the EC and the WTO: $A$ view on state aids, trade subsidies and direct taxation. [Doctoral Thesis, Maastricht University]. Intersentia. https://doi.org/10.26481/dis.20030122rl

Document status and date:

Published: 01/01/2003

DOI:

10.26481/dis.20030122rl

Document Version:

Publisher's PDF, also known as Version of record

Please check the document version of this publication:

- A submitted manuscript is the version of the article upon submission and before peer-review. There can be important differences between the submitted version and the official published version of record.

People interested in the research are advised to contact the author for the final version of the publication, or visit the DOI to the publisher's website.

- The final author version and the galley proof are versions of the publication after peer review.

- The final published version features the final layout of the paper including the volume, issue and page numbers.

Link to publication

\footnotetext{
General rights rights.

- You may freely distribute the URL identifying the publication in the public portal. please follow below link for the End User Agreement:

www.umlib.nl/taverne-license

Take down policy

If you believe that this document breaches copyright please contact us at:

repository@maastrichtuniversity.nl

providing details and we will investigate your claim.
}

Copyright and moral rights for the publications made accessible in the public portal are retained by the authors and/or other copyright owners and it is a condition of accessing publications that users recognise and abide by the legal requirements associated with these

- Users may download and print one copy of any publication from the public portal for the purpose of private study or research.

- You may not further distribute the material or use it for any profit-making activity or commercial gain

If the publication is distributed under the terms of Article $25 \mathrm{fa}$ of the Dutch Copyright Act, indicated by the "Taverne" license above, 


\section{Assessment and Recovery of Tax Incentives in the EC and the WTO}

A View on State Aids, Trade Subsidies and Direct Taxation 



\section{Assessment and Recovery of \\ Tax Incentives in the EC and the WTO}

\section{A View on State Aids, Trade Subsidies and Direct Taxation}

\section{PROEFSCHRIFT}

ter verkrijging van de graad van doctor aan

$$
\text { de Universiteit Maastricht, }
$$

op gezag van de Rector Magnificus,

Prof. dr. A.C. Nieuwenhuijzen Kruseman

volgens het besluit van het College van Decanen,

in het openbaar te verdedigen

op woensdag 22 januari 2003 om 16.00 uur

door

Raymond Hubert Christiaan Luja 


\section{Promotor:}

Prof. dr. R.G. Prokisch

\section{Beoordelingscommissie:}

Prof. dr. R.E.C.M. Niessen (voorzitter)

Prof. dr. P.L.H. van den Bossche

Prof. dr. J.G.A. van Mierlo

Prof. dr. H.E.G.S. Schneider

Prof. dr. J.M.F. Wouters (Katholieke Universiteit Leuven, België)

Van dit proefschrift verschijnt een handelseditie bij Intersentia in de serie Ius Commune Europaeum, nr. 41, onder ISBN 90-5095-278-X. 


\section{PREFACE}

When I started my research back in 1998 the term 'state aid' was unknown to many tax specialists except those with a special interest in European law. Only four years later, most tax advisors in Europe will have heard that there is a thing called 'state aid' that affects tax planning practice. But still only a few of them know what it actually means.

The evolution of the topic itself inspired me to do my research, but in the meantime it made it necessary to revise chapters again and again. Even though this thesis had to have a deadline, research in the field of fiscal state aids will and must continue of course in these turbulent times.

My first thanks goes to my supervisor Professor Rainer Prokisch for his guidance. He showed his confidence by giving me maximal latitude in writing my thesis and conducting my research. A second vote of thanks to Professor Ton Daniels who proposed the topic of fiscal state aid to me and who helped me through the initial stages of this research. I would also like to thank the members of the committee that assessed this PhD-thesis for their time and their useful comments. I am grateful to my colleagues at Maastricht University who encouraged me to finish my thesis on time.

This thesis could not have been written without the moral support of my family. I would like to express my thanks to my parents to whom I dedicate this book, to my partner Veronique and to my brother Patrick for the interest they have shown in my work during these years and for providing the necessary distraction. I am also grateful to my grandparents and to Veronique's parents for their concern.

Last but not least I would like to thank those persons who commented on some of my previous publications on this topic and drafts thereof for their constructive criticisms.

This thesis describes the situation as of 1 September 2002.

Maastricht, October 2002

Raymond Luja 


\section{TABLE OF CONTENTS}

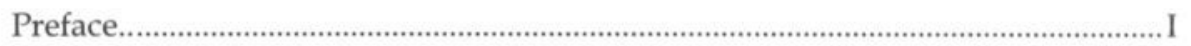

Table of Contents ..................................................................................................... III

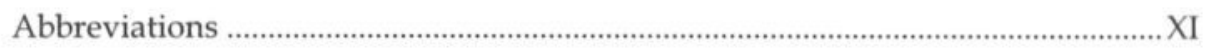

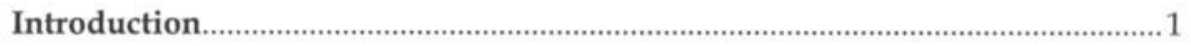

Chapter I - Tax Incentives between Politics and Economics ............................... 3

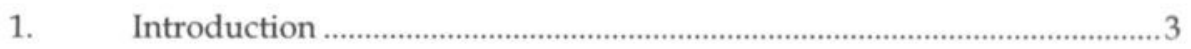

2. A Brief Economic Background of Fiscal Subsidisation...............................5

2.1. The Need for Government Subsidisation .....................................................

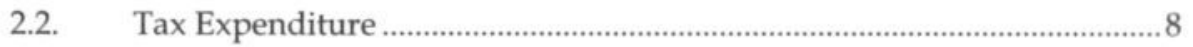

2.3. Some Principles of Taxation .................................................................11

2.3.1. Revenue Collection: Equity, Fairness and Neutrality ................................11

2.3.2. Transparency and Administrability ............................................................12

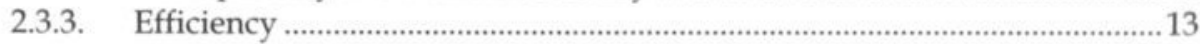

2.4. Cash Grants versus Tax Incentives.......................................................14

2.4.1. Visibility......................................................................................................14

2.4.2. Confidentiality and Sensitivity .........................................................15

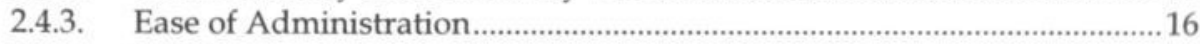

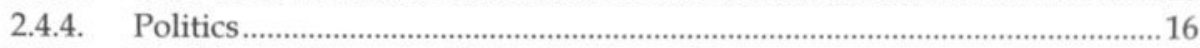

2.4.5. Tax Expenditure as a Policy Instrument.....................................................17

2.5. Domestic Periodical Review ...................................................................19

2.6. The Need for Supranational Subsidy Regulation........................................2 20

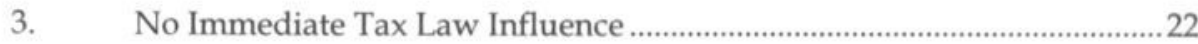




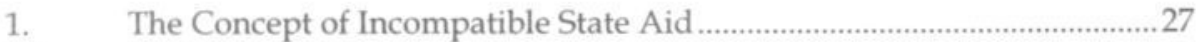

1.1. Article 87(1) EC..............................................................................................27

1.2. Element 1: The Presence of a Benefit............................................................29

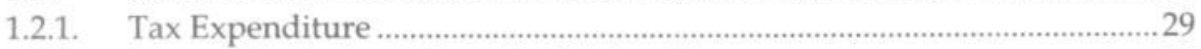

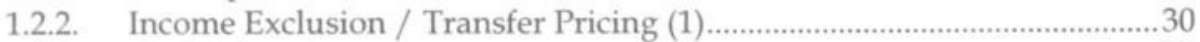

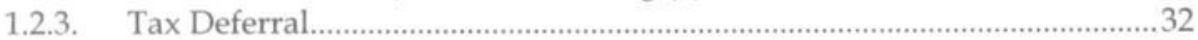

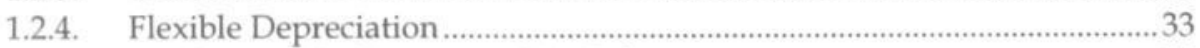

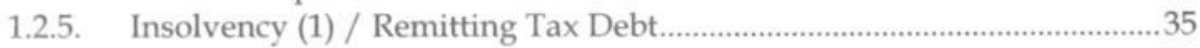

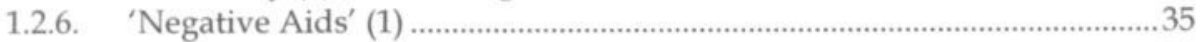

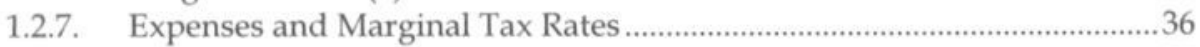

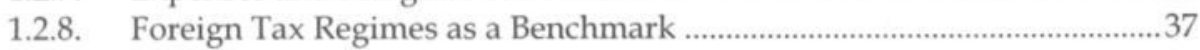

1.2.9. Article 86(2) EC: General Economic Interest.................................................38

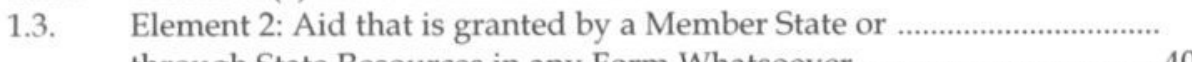
through State Resources in any Form Whatsoever ......................................40

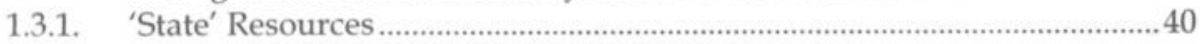

1.3.2. The Intent to Transfer Resources ...................................................................... 41

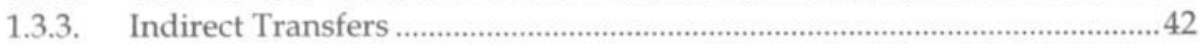

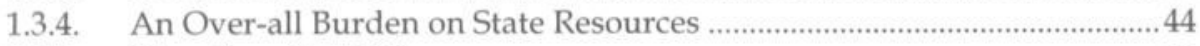

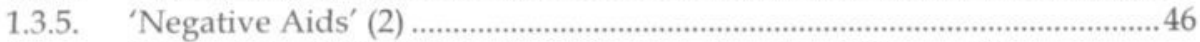

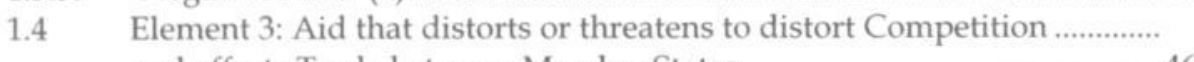
and affects Trade between Member States .......................................................46

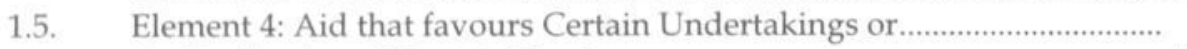
the Production of Certain Goods ...................................................................49

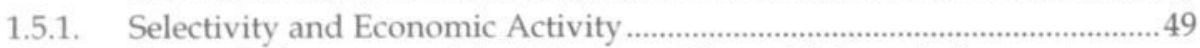

1.5.2. General Measures and the 'Nature or General Scheme' of .......................

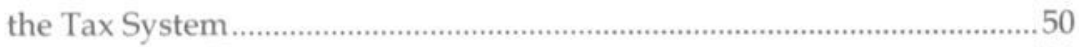

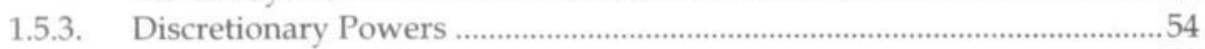

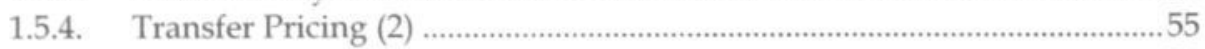

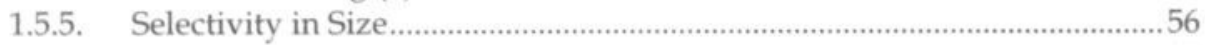

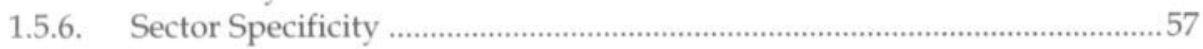

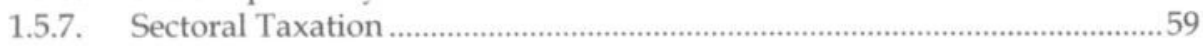

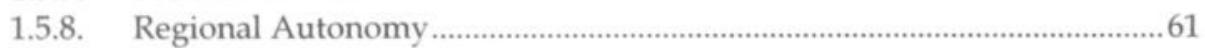

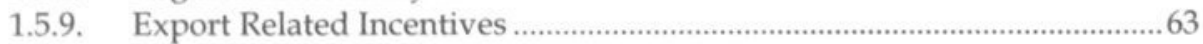

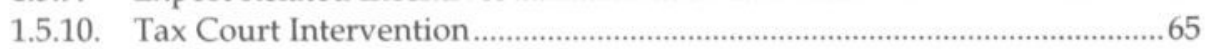

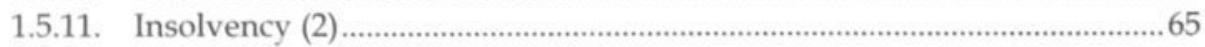

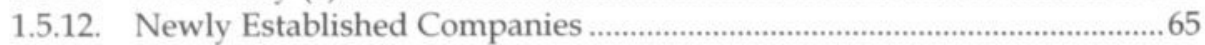

2. Compatibility with the Common Market .....................................................66

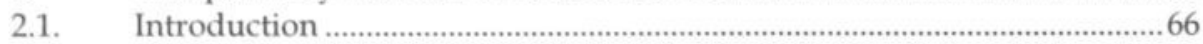

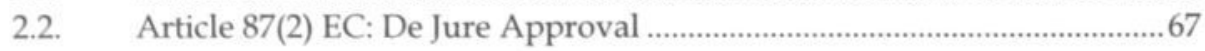


2.3. Article 87(3) EC: Discretionary Approval .................................................68

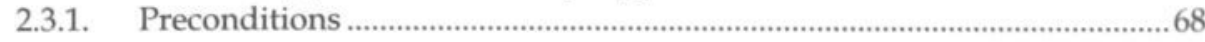

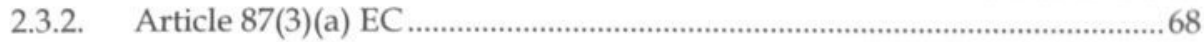

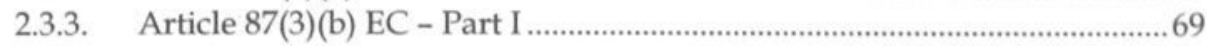

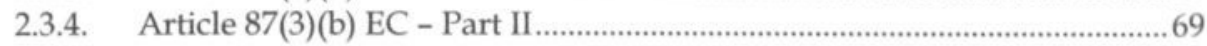

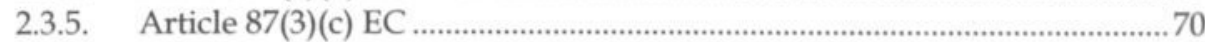

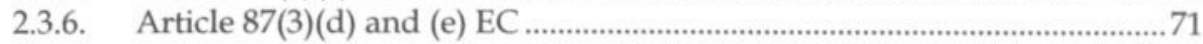

2.4. Article 88(2) EC: Council Intervention......................................................71

3. Special Provisions …......................................................................................... 72

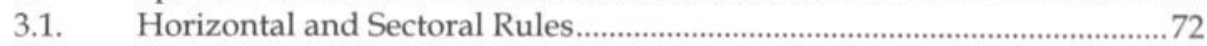

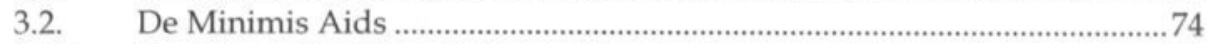

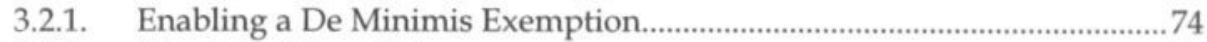

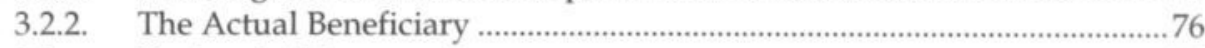

3.3. Regional Aids................................................................................................77

3.4. Aid to Small and Medium Sized Enterprises / Training Aid ...................80

3.5. Environmental Aid ......................................................................................... 82

3.6. Rescuing and Restructuring Aid................................................................. 83

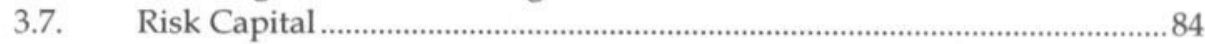

4. State Aid Procedure ......................................................................................... 85

4.1. Ex ante Supervision: Article 88(3) EC ........................................................... 85

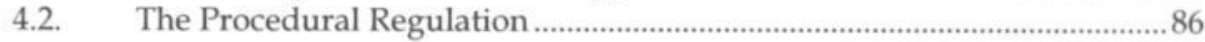

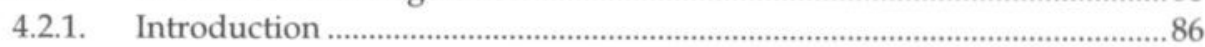

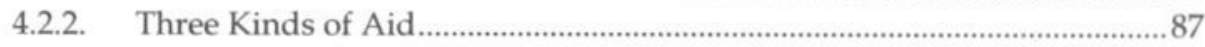

4.2.3. The Duty to Notify .......................................................................................... 90

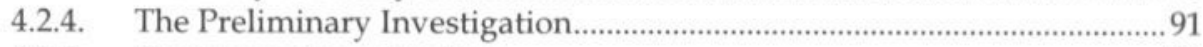

4.2.5. The Formal Investigation ........................................................................... 92

4.2.6. Procedure Regarding Unlawful Aid ............................................................93

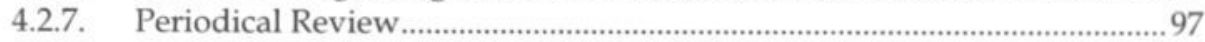

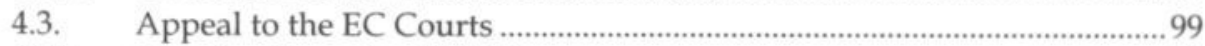

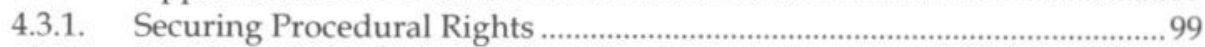

4.3.2. Entering Proceedings........................................................................................ 100

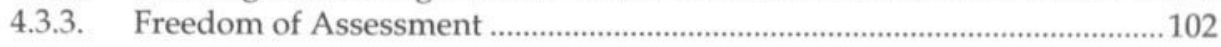

Chapter III - State Aids and Member State Taxation ....................................... 105

1. Harmful Tax Competition ...........................................................................105

1.1. The Proposed Role of State Aid .................................................................... 105

1.2. Crossing the Outer Limits of State Aid Control .........................................108

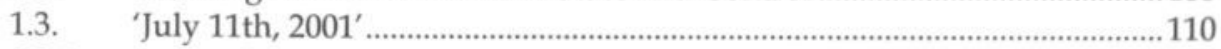

1.3.1. An Evolution of the Common Market? ..........................................................110

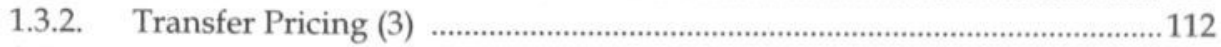

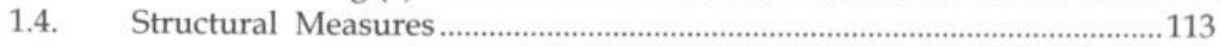

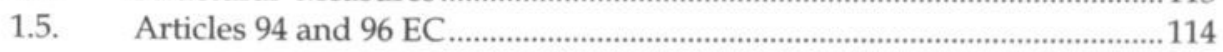


2. Safeguarding National Tax Bases 115

2.1. The Status of an Approved Tax Incentive ....................................................115

2.2. Substance Criteria ...........................................................................................117

2.3. Avoidance of Double Taxation: Tax Exemptions and Tax Credits...........120

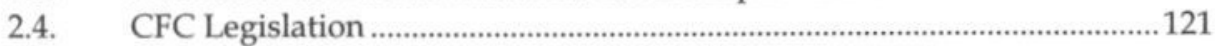

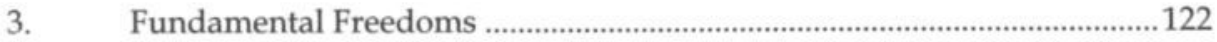

Chapter IV - The WTO Subsidies Framework ..................................................125

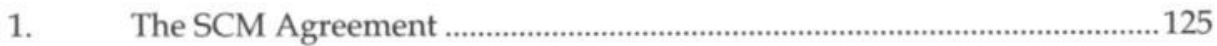

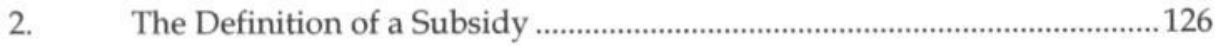

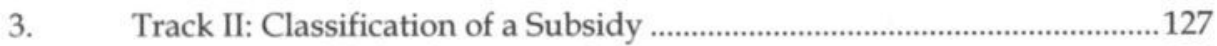

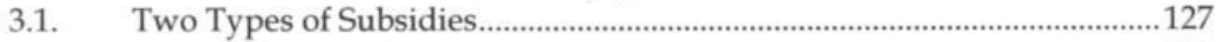

3.2. Prohibited Subsidies .......................................................................................... 128

3.2.1. Prohibited Subsidies Classification: Export ................................................128

3.2.2. Prohibited Subsidies Classification: Import ..............................................131

3.2.3. Prohibited Subsidy Procedure ........................................................................ 132

3.2.4. Judicial Standards in the Dispute Settlement Process .................................134

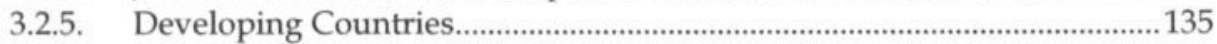

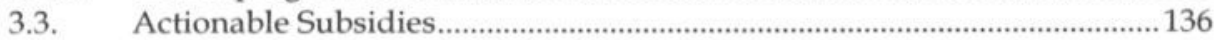

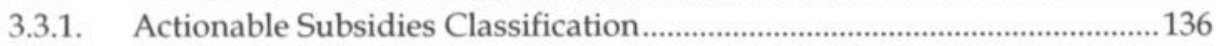

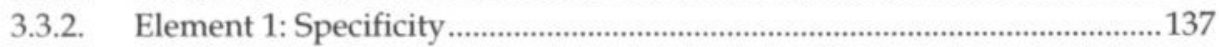

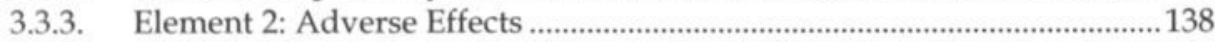

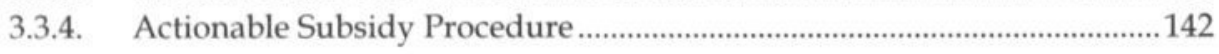

4. Track II: Withdrawal of Subsidies ................................................................143

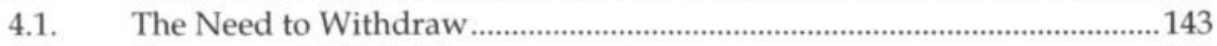

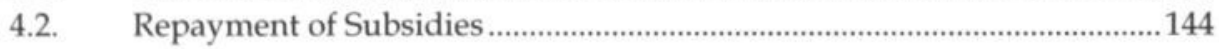

5. Track II: Aspects of Prohibited Fiscal Subsidies ........................................148

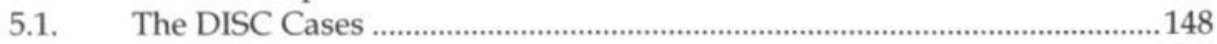

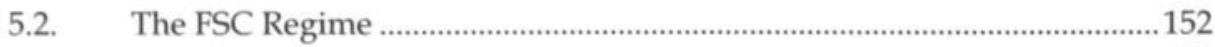

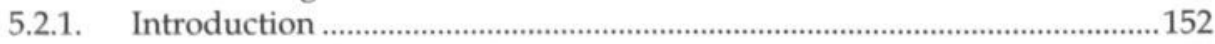

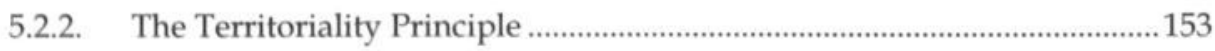

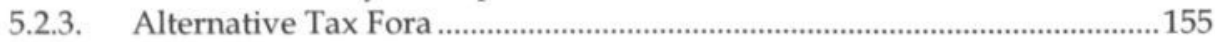

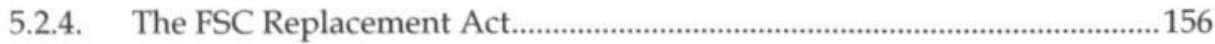

5.2.5. Failure to Implement (1): the 21.5 Panel ......................................................158

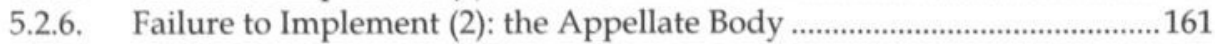

5.2.7. Failure to Implement (3): the Arbitrator....................................................163

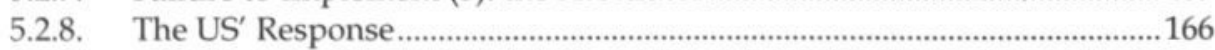

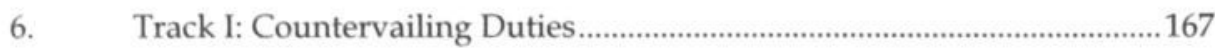


6.1. The Unilateral Duty ..................................................................................167

6.2. Countervailing Duty Procedure ………...............................................169

7. Track I: Fiscal Aspects of Trade Subsidies..................................................171

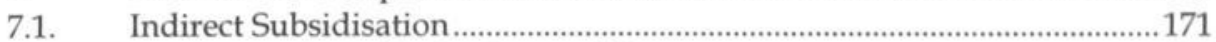

7.2. Tax Exemptions, Deductions and Losses ................................................172

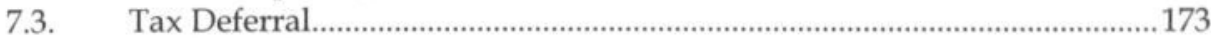

7.4. Accelerated Depreciation .............................................................................175

7.5. Discretion and Thresholds........................................................................177

7.6. Attribution of Fiscal Subsidisation ...........................................................178

7.6.1. Attribution to Imports .........................................................................178

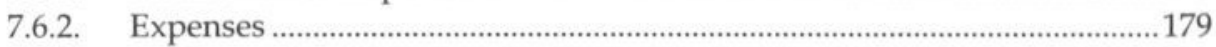

7.7. The Subsidy Benchmark .........................................................................180

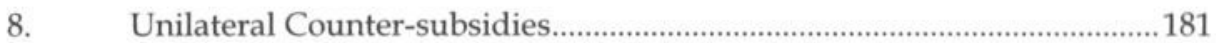

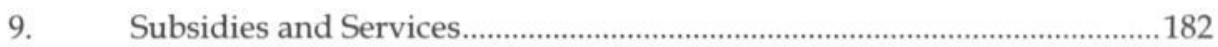

Chapter V - The WTO Framework versus State Aid ..............................................185

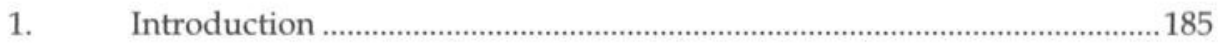

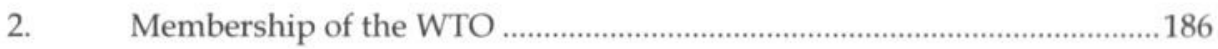

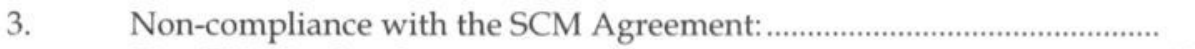

Non-EU Member States..............................................................................186

4. Non-compliance with the SCM Agreement: EU Member States...............187

4.1. Complaining WTO Member States ……………………………………......187

4.2. Community-based Competitors ..................................................................188

4.3. Community-based Beneficiaries .................................................................... 191

5. Capita Selecta of Disparities between Track II and

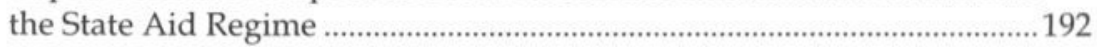

5.1. Similarities and Differences....................................................................192

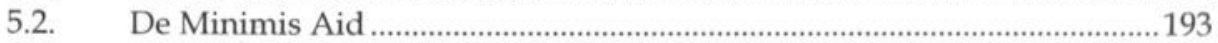

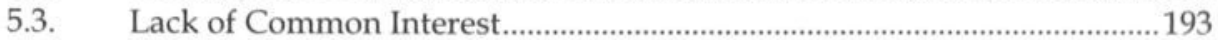

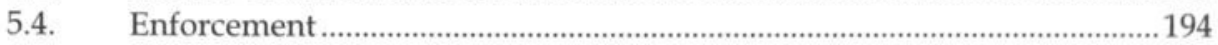

5.5. Recovery $\neq$ Recovery ............................................................................195

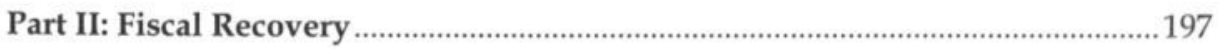

Chapter VI - Recovery of Unlawful Tax Incentives within the EC .....................199

1. The Implicit Power to Recover ...............................................................199 
2. National Procedural Autonomy

3. Absolute Impossibility to Recover...................................................................204

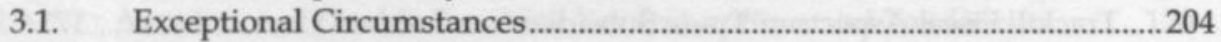

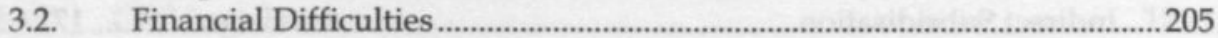

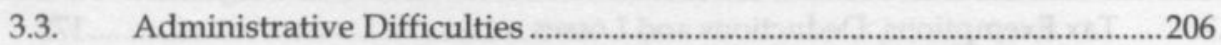

3.4. National Court Order ....................................................................................... 208

4. Legitimate Expectations of the Recipient .....................................................209

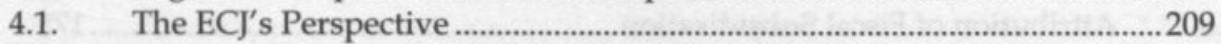

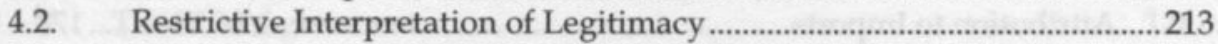

4.3. The Commission's Actions:

Foreseeability, Expediency and Time Limits .................................................214

4.4 Risk of Annulment of a Favourable Decision ..............................................219

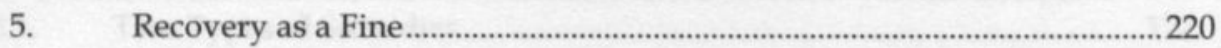

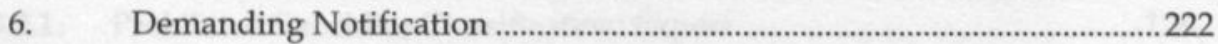

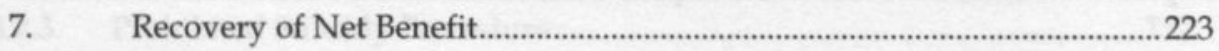

Chapter VII - Recovery in the Netherlands.........................................................227

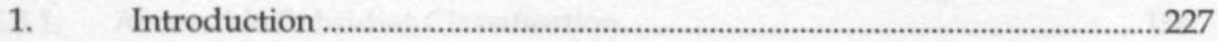

2. Legitimate Expectations from a Dutch Perspective ...................................227

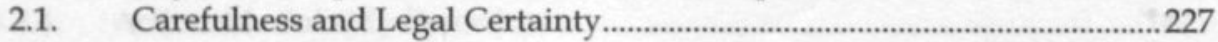

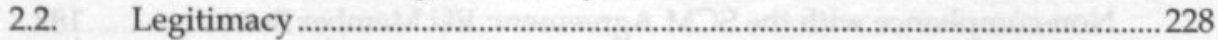

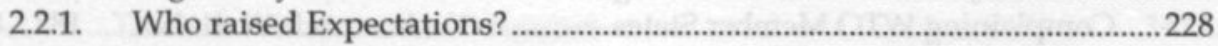

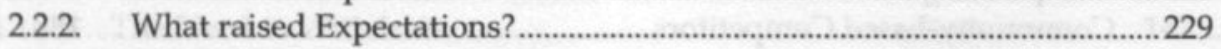

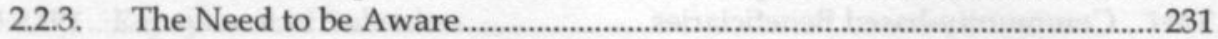

3. Tax Incentives and the General Law regarding State Taxes......................232

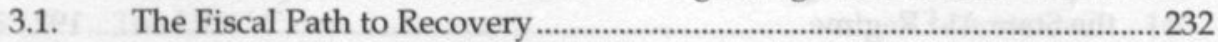

3.1.1. Supplemental Payment of Taxes......................................................................22

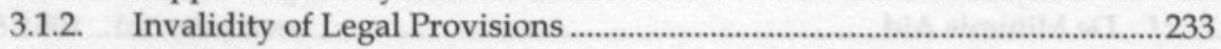

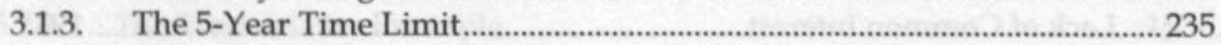

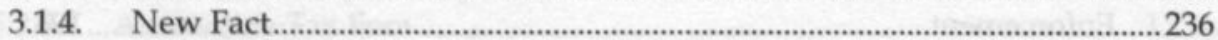

3.2. Civil Law Concepts for Administrative Recovery .......................................238

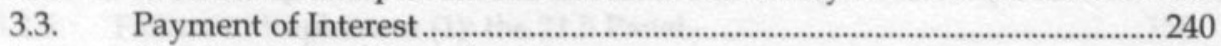

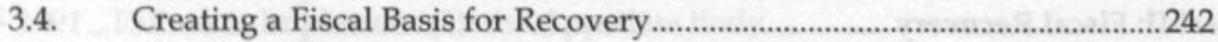

3.4.1. New Procedures ............................................................................................... 242

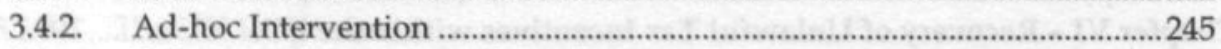

3.5. Voluntary Suspension of Benefits..................................................................245 
Conclusions

Chapter VIII - Theory, Policy and Practice

1. A Matter of Relativity

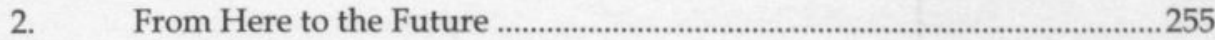

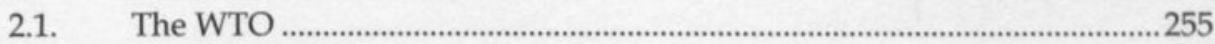

2.2. The European Communities...................................................................256

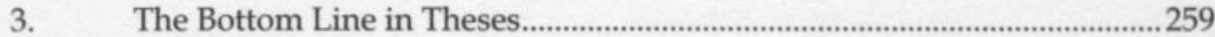

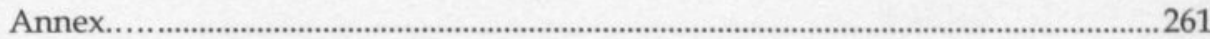

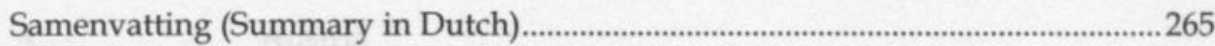

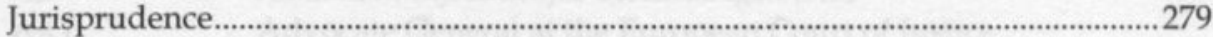

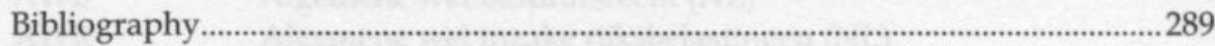

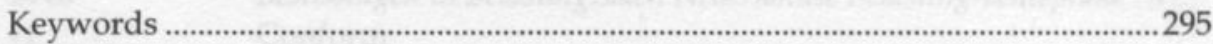

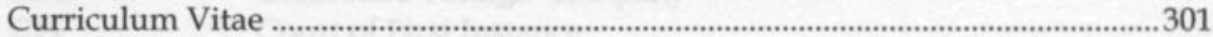


Table of Contents 


\section{ABBREVIATIONS}

$\begin{array}{ll}\text { A } & \text { Austria } \\ \text { AB } & \text { Administratiefrechtelijke Beschikkingen (NL) } \\ \text { A-G } & \text { Advocate General at the European Court of Justice } \\ \text { AWB } & \text { Algemene wet bestuursrecht (NL) } \\ \text { AWR } & \text { Algemene wet inzake rijksbelastingen (NL) } \\ \text { BNB } & \text { Beslissingen in Belastingzaken Nederlandse Belastingrechtspraak (NL) } \\ \text { cf. } & \text { Conform } \\ \text { CFC } & \text { Controlled Foreign Company } \\ \text { CFI } & \text { Court of First Instance } \\ \text { CFR } & \text { Code of Federal Regulation (US) } \\ \text { CVD } & \text { Countervailing duty } \\ \text { DG } & \text { Directorate General (of the European Commission) } \\ \text { DISC } & \text { Domestic International Sales Corporation (US) } \\ \text { DSB } & \text { Dispute Settlement Body } \\ \text { DSU } & \text { Dispute Settlement Understanding } \\ \text { EC } & \text { European Communities or Treaty Establishing the European } \\ & \text { Communities (in reference to Articles) } \\ \text { ECJ } & \text { Court of Justice of the European Communities } \\ \text { ECR } & \text { European Court Records } \\ \text { ECSC } & \text { European Coal and Steel Community } \\ \text { eds. } & \text { Editors } \\ \text { e.g. } & \text { For example } \\ \text { ETI } & \text { Extraterritorial Income Tax (US) } \\ \text { FR } & \text { Federal Register (US) } \\ \text { FSC } & \text { Foreign Sales Corporation (US) } \\ \text { GATS } & \text { General Agreement on Trade in Services } \\ \text { GATT } & \text { General Agreement on Tariffs and Trade 1994 } \\ \text { I } & \text { Italy } \\ \text { i.e. } & \text { In essence } \\ \text { NJ } & \text { Nederlandse Jurisprudentie (NL) }\end{array}$


NL

NLG

no.

OECD

OJ

$\mathrm{p}(\mathrm{p})$.

$R \& D$

SCM

SMES

UK

US

VAT

vol.

WTO
The Netherlands

Dutch Guilders (former currency unit)

Number / issue

Organization for Economic Co-operation and Development Official Journal of the European Communities

Page(s)

Research and Development

Subsidies and Countervailing Measures

Small and Medium-sized Enterprises

United Kingdom

United States of America

Value Added Taxes

Volume

World Trade Organization 
Introduction

\section{Creativity}

"The creativity of national governments [...]

in some cases resembles the creativity of individual tax planners.

Even though they pursue different objectives, both try to find the loopholes in the system and attempt to avoid anti-subsidies rules or taxes, respectively. "

R. Lopez-Mata

The Tax Lawyer, 2001 
nomsulsonit

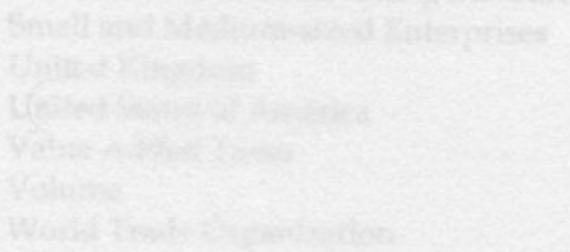

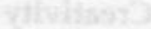

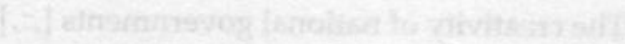

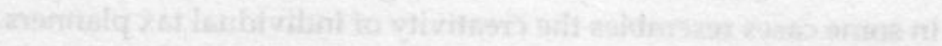

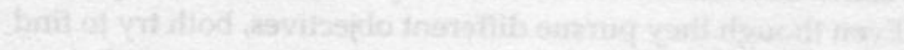

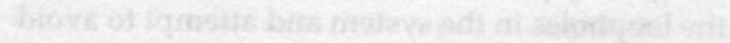

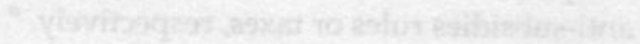

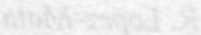

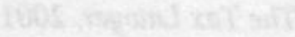


Chapter I

\section{TAX INCENTIVES BETWEEN POLITICS AND ECONOMICS}

\section{Introduction}

Taxation and international trade law have a long-standing relationship. One of the most complex issues in this field is the granting of fiscal subsidies to enterprises and entrepreneurs that operate in the international market. There are multilateral Treaties, Agreements and other kinds of regulations that intend to regulate the granting of government subsidies, including subsidies that are part of the fiscal framework.

Countries may design their tax systems any way they want as long as they abide by standards that are internationally accepted. ${ }^{1}$ Fiscal incentives are not and should not be excluded from regulations on trade subsidisation just for being part of what was once regarded to be the absolute fiscal sovereignty of States. The objective of this research study is to determine the limitations that international regulations impose upon Member States of the European Communities in regard to the use of fiscal subsidies.

Originally, it was the intention to merely focus on the so-called "state aid regime" in the European Communities (hereinafter: the 'EC'). However, European legislation is not the only touchstone for national subsidisation policy. The World Trade Organization (hereinafter: the 'WTO') provides for its own subsidy framework, which does not fully coincide with the EC's state aid framework. It provides more possibilities for subsidisation on the one hand, but it imposes restrictions to the EC's framework on the other. It was therefore decided to include the WTO regulatory framework in this research be it limited for the most part to the Agreement on Subsidies and Countervailing Measures (hereinafter: the 'SCM Agreement'). By determining the common denominator of both frameworks, the limitations to fiscal subsidisation imposed upon EC Member States will be established. 
This study will try to provide an answer on the following questions under the assumption that a decision has been made by the government of an EC Member State to grant financial support to enterprises through the income tax system or the corporation tax system:

- What are the limitations that the European Community's state aid regime and the WTO's Subsidy Agreement set in regard to granting fiscal support by the governments of the Community's Member States?

- How can a fiscal incentive be fit into or kept out of the state aid framework and the framework provided for by the SCM Agreement?

- Are there any differences between the Community and WTO framework in regard to fiscal incentives, and if so, what could be the consequences for an EC Member State that meets the first and violates the latter?

- If a fiscal incentive is granted in violation of the EC State Aid regime, what may be the consequences thereof?

The remainder of this book is organised as follows. The first part of this book (chapters II-V) contains an introduction in the regimes of the EC and WTO. It is not the objective to give an exhaustive, in-depth overview of the EC's state aid regime with all of its detailed regulations and guidelines or of the WTO's Subsidies regime. Doing so would mean no more than copying some of the famous handbooks on these issues without contributing to something new. This study will rather address the most important and controversial aspects of both regimes with the emphasis on taxation issues. In order to keep focussed on the main regimes, agricultural aids and subsidies will not be covered. They are mainly governed by other extensive sets of EC and WTO rules that substantially deviate from the general regimes discussed.

In chapter II I will review some of the key issues in the field of state aid and taxation. The definition of 'state aid' will be analysed and applied to the fiscal framework. An introduction to state aid procedure will also be provided. In chapter III there will be an outline of the competitive environment in which the state aid regime operates with special emphasis on its relation to harmful tax competition and the fundamental freedoms provided for in the EC Treaty. Chapter IV will provide for a description of the WTO framework on trade subsidisation, with special attention for its application in the fiscal sphere and certain procedural issues including remedy procedures. Chapter $\mathrm{V}$ contains an analysis of potential areas of conflict when the WTO Subsidies Agreement and EC state aid regulations apply simultaneously.

As we will see, the evolution of the broad definition of the EC state aid prohibition steadily increases the uncertainty in regard to direct tax incentives and their compliance with the EC Treaty. Taxpayers as well as national tax authorities should be aware of the possible consequences of violating state aid provisions. The second part (chapters VI and VII) of this book will focus in-depth on the potential consequences of non-compliance in regard to the EC state aid regime. Chapter VI provides for an introduction into the 'recovery' of unlawful fiscal aids, i.e. the payback of tax incentives that were granted in violation of state aid provisions. 
Chapter VII will focus on recovery of fiscal aids in the Netherlands in order to illustrate the problems that may arise within the legal system of a Member State when the European Commission orders recovery. Chapter VIII will take a short look into the future of fiscal trade subsidisation and will provide for some conclusions.

This study focuses on subsidies in corporation tax laws and (entrepreneurial) income tax laws. It does not contain a full analysis of tax schemes in the EC and WTO Member countries. However, certain schemes will be discussed that have already been assessed by the proper EC and WTO authorities in order to provide some guidance for the analysis of the relationship between direct taxation and the provisions covering trade subsidisation.

\section{A Brief Economic Background of Fiscal Subsidisation}

\subsection{The Need for Government Subsidisation}

As said before, this study is based on the assumption that a decision is made by a government not only to grant financial support but also to grant such support through the fiscal system. In order to put the issue of fiscal subsidisation in the proper perspective, the emphasis cannot be on the regulatory aspects alone. The greatest danger of providing a regulatory framework on granting financial support - either through the fiscal system or otherwise - is that it may contribute to the misunderstanding that trade subsidisation as such is "good", "fair" or "appropriate" by definition as long as it remains within the legal limits set. It should not be assumed that there is an inherent need for subsidisation, although there may be circumstances in which there will be a legitimate need for subsidies in order to address certain economic difficulties. Therefore, prior to discussing the legal competitive perspective of fiscal subsidisation there will be an introduction into the economical background in the next section of this chapter. The emphasis will be on the when and why of fiscal subsidisation.

In this paragraph 2.1 we will look into the need and motives for government subsidisation. Once it is determined that there is such need, it may be considered to use the fiscal system to implement a subsidy scheme. Paragraph 2.2 will look into the methods that are available for such purpose. In order to emphasise the importance of not neglecting the principles of taxation in trying to use the fiscal system for the purpose of subsidisation, paragraph 2.3 will give a basic description of these principles. Then paragraph 2.4 will look into the issue whether these fiscal methods are to be preferred over non-fiscal methods like providing for cash grants. Paragraph 2.5 will focus on the importance of keeping track of (fiscal) subsidy schemes. Last but not least, paragraph 2.6 will try to explain the need for regulation of government subsidisation by supranational bodies, especially in regard to crossborder effects. But first, we will look into the necessity of government subsidisation.

Correction of market failure and the stimulation of economic development are among the most important objectives of granting financial support by governments, at least from an economic point of view. There are different kinds of market failures that could be addressed by subsidies. 
- One kind of market failure could be that a country is unable to attract certain sectors of industry, such as high-tech. Instead it is saddled with a far less profitable manual labour industry due to lack of facilities, knowledge or qualified personnel. Subsidisation may lead to better training of staff, research and development activities, better (telecommunications) infrastructure and so on. This in turn could attract new and more advanced activities and investments into the territory of a country. All this could lead to an increase of national economic welfare.

- SCHWARTZ and CLEMENTS refer to the free rider problem as a market failure. They illustrate the free rider aspects by referring to research and development. Certain companies underinvest in R\&D and try to use the knowledge obtained by others. ${ }^{2}$ In such case subsidisation of R\&D could be welcome, not only to compensate those who already contribute their part but also to get others to make their own R\&D contribution instead.

- Market failure may also exist in the form of informational asymmetries. For instance, banks tend to be risk aversive towards smaller enterprises and infant industries even though their business plans are viable. In such cases, the government could create tax incentives to compensate small and/or starting companies for these financing difficulties. The alternative could be to create tax incentives to promote more risky investments in small and medium sized enterprises, either by individuals (as an alternative to savings), banks or other financial institutions.

- Whenever the market fails to create conditions in which environmentally friendly investments in machines and processes would be profitable, tax incentives could also be useful to stimulate such investment in the benefit of the over-all welfare level in a country. ${ }^{3}$ Without an incentive to invest in the environment (or any regulatory provision that tells them to do so), corporations would not consider to invest when they face the risk that competitors would be able to operate at a lower cost level by not caring about the environment. ${ }^{4}$

Yet, in politics there are other motives to grant subsidies apart from market failure:

- As we will see in chapter II there is common consensus among EC Member states that subsidies would be appropriate to facilitate certain policy objectives. Without elaborating on these subjects for the time being, the EC accepts subsidies to stimulate underdeveloped regions with high unemployment where the local market by itself cannot provide for sufficient stimulant to promote development and employment. It also accept subsidies to facilitate environmental-

3 See also Nicol_Aides / Bil.AL. (1999), p. 30.

Provided that the investment in the environment does not produce a financial benefit by itself, such as the attraction of many new customers that are interested in environmentally friendly produced products or the exemption of ecological taxes and duties. 
friendly investments and research and development activities; their economic background has been set forth already. In addition the EC recognises among other the need for emergency assistance in case of natural disasters, in order to enable affected enterprises to get back in or stay in business. The latter cannot be seen as a real market failure. The enterprises could pass on its (extraordinary) costs to the consumers or users of its goods and services, with the logical consequence that companies that did not suffer such costs would be brought in a better competitive position. Yet, it is a political decision - and not an economic one - that affected enterprises cannot be expected to bear all costs that arise from a catastrophe.

- Of special concern are infant industries, especially in developing countries. These industries will need some time to get settled and to provide competitive products in an efficient manner. Since these industries will be lacking the necessary experience in the beginning, they will work less efficient than their foreign competitors. In order to overcome this 'temporary' setback, export subsidies could be appropriate to enable these infant industries to offer their products at a competitive price on the international market. For this purpose the WTO does exclude least developed countries from the prohibition of granting export subsidies for the time being, as we will see in chapter IV.3.2.5. In these cases, there neither is real market failure. Those industries that work most efficient and are able to offer the same product for the lowest price should be able to set off their products, putting its less efficient competitor out of business. Yet, there is a political commitment among developed countries to allow the granting of export subsidies in order to enable developing countries to create a competitive industry to facilitate their development.

- The most controversial 'rationale' for financial support is the assisting of enterprises that are facing bankruptcy. From a political point of view, the urge to grant aid to firms in desperate need will be tremendous. No government would want to be blamed for not doing anything to assist such firms, especially in case thousands of employees are to be dismissed. Yet, from an economic point of view it would be one of the foreseeable results of free trading. Domestic companies that cannot compete with other more efficient companies domestic or abroad - either in quality, price or otherwise - get the worst of it. In these cases governments will have to consider the consequences of mass-unemployment on the national (and regional) economy. Considering the costs of granting unemployment benefits and the fact that former employees will consume far less, a nation could be better of by spending a certain amount of money on keeping a company in business. This again is not a market failure, but a mere expression of political and social concern. ${ }^{5}$

The European Commission calls it the "moral hazard" governments may face when the providing of assistance to failing domestic industries is at issue. (State Aid Scoreboard of 18 July 2001, COM 2001(412) final, p. 30.) 
We must make sure that financial support is not self-containing. It should rather accomplish that its rationale vanishes, thereby making itself abundant. Subsidisation may take away the incentive to address market failure and inefficiency unless it is conditioned upon making the necessary adjustments. If an enterprise or an entire sector of industry can compete on the international market without having to worry about the consequences of market failure, it will not be at urge to try to contribute to solving such failure. Why would an industry make certain investments and lose a subsidy in the end if it can keep a subsidy without having to go to the trouble of making investments at all. The mere granting of compensation for existing failures and market inefficiency will probably not lead to the necessary stimulation of new measures that would undo such failures and inefficiency. If government aid only compensates for existing failures in order to enable the national market to compete at more favourable conditions, the failure itself may be hidden but not gone. Subsidies should therefore be temporary by definition. Trying to compensate for existing economic disadvantages by government subsidisation without stimulating the removal of their cause can merely be a second-best solution. ${ }^{6}$

Subsidisation should not introduce new considerable distortions in the market in an attempt to replace existing distortions. When a Member State would want to create tax incentives and focus on assisting the targeted beneficiaries, it should give due consideration to the effects on the economy as a whole and the assisted sector and related sectors in specific. One of the dangers of subsidisation is that it may lead to the crowding out of unsubsidised competition, even if that competition would be more cost efficient than its subsidised competitor. ${ }^{7}$ This is one of the dangers that provided a common interest for many countries to agree upon some kind of regulation of subsidisation, as will be addressed in paragraph 2.6 hereafter.

\subsection{Tax Expenditure}

If it is decided that there is a need for financial support, it may be considered to grant such support in the form of fiscal benefits. We will now look at how such benefits may be incorporated in the fiscal system. As for any subsidy scheme, the amount of fiscal subsidy that is to be granted should be determined or at least estimated in advance.

An assessment must be made of what part of tax revenue is not collected as a result of a fiscal subsidy compared to the revenue collected in the absence thereof. We therefore need to determine the amount normally due in order to make such comparison. The non-collection of revenue that results from granting a fiscal subsidy is commonly referred to as 'tax expenditure'. In order to define the normative tax structure as a benchmark for tax expenditure, MCDANIEL and SURREY 
have defined several criteria. ${ }^{8}$ A provision can be part of the normative structure if it is necessary to determine the normal tax base in accordance with the fundamental nature and purpose of taxation: revenue collection. SURREY and SUNLEY signal the specific problems concerning non-taxation of capital gain; a country may consider such gain not to be income and not include it in the tax base at all. It would thus be of a fundamental, normative nature. ${ }^{9}$ The same is true for provisions in regard to the general rate structure, provisions necessary to determine the units liable for tax (e.g. persons, enterprises, families), provisions to determine the tax within the imposition period (e.g. attribution per fiscal year), provisions necessary to implement tax in regard to international transactions, and those necessary to administer the tax in general (e.g. normative mechanical rules to reduce administrative difficulties in regard to valuation, collection etc.). ${ }^{10}$ In addition, the OECD mentions the setting of the general rate structure, standard double taxation provisions, accounting principles and general limitations on deductions. ${ }^{11}$ All these criteria may be part of the core of any income tax or corporate tax system: the revenue raising framework.

Special preferences are embedded in most if not all tax system, ${ }^{12}$ without necessarily resulting in tax expenditure. In regard to the expenditure status of tax rates MCDANIEL and SURREY indicate that applying a special tax rate to a particular type of income or activity presumably creates an expense. ${ }^{13}$ As long as the differentiation in rates is made on the level of corporate/entrepreneurial income versus labour income and/or capital income, I consider this differentiation to be part of the normative tax system. But within these groups further distinction may give rise to tax expenditure. Special rates at a sub-level, such as for corporate export income, labour income from certain sectors of industry, or investment income from capital for specified corporate investment may lead to expenditure. Applying different rate schedules to different taxable units does not create expenditure, ${ }^{14}$ at least not at the level of corporations, entrepreneurs, individuals and families. But it can create expenditure in case of sub-level diversification, such as special rates for multinational corporations or for entrepreneurs and entities active in certain sectors of industry. MCDANIEL and SURREY also provided some examples on the expenditure status of certain types of administrative provisions. Allowing

MCDANIEL / SURREY (1985).

In case capital gain is included in the concept of income, but (fully) exempt from taxation for the purpose of stimulating savings or investment then there would be some form of expenditure. Thus SURREY / SUNLEY (1976), p. 20. Other examples of normative exclusions could be not regarding gifts and bequests as income according to SURREY (1973), p. 94.

MCDANIEL / SURREY (1985), pp. 9-10.

Report on "Tax Expenditures - Recent Experiences", OECD, Paris, 1996, pp. 9-10.

See also SURREY / SUNLEY (1976), pp. 16-17.

MCDANIEL / SURREY (1985), p. 49.

Ibid. 
consolidated tax returns by groups of controlled companies does not constitute tax expenditure. ${ }^{15}$ There could be an element of expenditure if such consolidation would be restricted to certain groups (for instance multinational groups active in a certain sector of industry) or to certain types of income (for instance export-related income). There could also be expenditure when the tax administration is more lenient in the application of rules covering loss carry over of operating expenses for certain taxpayers. ${ }^{16}$

Back in 1973 SURREY defined the operational aspects of tax expenditure. ${ }^{17}$ The methods of operation he defined can be set off against the successive stages of income tax determination. ${ }^{18}$ At the first stage of determining gross income there can be exclusions of gross income (tax exemptions). In addition, deferral of current tax liability is possible by accelerated deductions (i.e. accelerated depreciation of assets or short-term amortisation) that reduces gross income. ${ }^{19}$ Second, there can be made subtractions from gross income in calculating the taxable income (tax deductions). Third, the taxable income can be multiplied by a special tax rate rather than the normal statutory rate. Fourth, special tax credits may be granted that may be deducted from the calculated amount. These methods of operation will frequently recur in the following chapters. More specifically the operation of tax incentives will be at issue in the following chapters, which are "tax expenditures that induce certain activities or behaviour in response to the monetary benefits available." 20

In an attempt to describe some of the characteristics of tax expenditure, the OECD took the position that tax expenditure must have a certain purpose other than the efficient operation of the tax system. That purpose should be achievable by non-fiscal measures. Above all the government should be able to alter its tax system so that the tax expenditure could be eliminated since it should not be an inherent part of the normal system by definition..$^{21}$

Ibid., p. 53.

MCDANIEL AND SURREY (1985, p. 58) point out that not allowing carryover of net operating loss at all can rather be considered to be a tax penalty. Normal loss carryover provisions are a necessary part of a tax system in regard to income fluctuation in regard to annual accounting periods.

SURREY (1973), pp. 92-125.

The method of operation of a tax incentive should be chosen with care. Tax exemptions, tax deferrals and tax deductions will often favour taxpayers with higher incomes more than those with lower (or even none or negative) incomes. A tax credit on the other hand would create a more equal (absolute) benefit for all. Full (absolute) equality could be reached by paying out the remaining part of any tax credit (due to absence of creditable income). Also MCDANIEL / SURREY (1985), p. 56. In 1973 SURREY pointed out that politicians of that time had a feeling that mere postponement of tax debt is not much of an advantage, thereby disregarding just how valuable timing differences may be (pp. 108-109).

Thus SURREY (1973), p. 126. He concludes that nearly all tax expenditures can be considered tax incentives. Report on "Tax Expenditures - Recent Experiences", OECD, Paris, 1996, pp. 9-10. 


\subsection{Some Principles of Taxation}

\subsubsection{Revenue Collection: Equity, Fairness and Neutrality}

Whenever governments intend to use their tax system as an instrument to steer behaviour, they should not loose sight of the basic principles of taxation. ${ }^{22}$ The main purpose of taxation is to raise the revenue necessary to finance the government's policy and actions. WAGNER stresses that the financial principles of taxation, concerning efficiency in revenue collection (i.e. raising yield and flexible adjustment of taxation to practice) are at the basis of any tax system. They are an essential part - in WAGNER's view even the most important part - of the basic principles of taxation. ${ }^{23}$ A second set of principles he defined are the economic principles of revenue raising, which urge us to make a correct choice of sources (enterprises, individuals, capital) and methods of taxation (income tax, wealth tax, value added tax) to ensure effective taxation, in order to prevent tax shifting and alike.

WAGNER puts the principles of justice third in line, especially the principles of universality and equality of taxation. The first provides that all persons should be taxed, the second provides that this should be done on the basis of an equal proportion of taxation to income. ${ }^{24}$ I.e. persons with a higher level of income (or better, a higher standard of wealth) should bear an amount of tax that is at least proportional compared to the amount payable by those with a lower level of income. This is the so-called vertical equity principle. As its counterpart, the principle of horizontal equity sets forth that persons or enterprises with the same level of income should bear the same amount of tax and receive an equal benefit from government policy and actions financed therewith.

WAGNER also adds the principle of social welfare. ${ }^{25}$ Certain infringements on the principles of universality and equality may be regarded acceptable from a social point of view in an attempt to having the rich support the poorer part of society. The concept of income redistribution among citizens aims at having the 'rich' part of the population pay more than the less wealthy. This kind of taxing in accordance with economic capacity favours some sort of progressive form of taxation, and could therefore endanger the equality principle in its purest form (i.e. equality on the basis of proportionality). In addition, a system of reduced or non-taxation of the poorest part of the population may infringe on the principle of universality. The extent to which social objectives may infringe on the financial principles of equality and universality is part of the political struggle, thus WAGNER.

See also Westin (1997), pp. 61-63.

WAGNER quite rightly pointed out that "no single principle of taxation can ever be decisive in itself. The various principles are all relevant to any one problem of taxation." He stressed that the principles he defined (some of which will be discussed hereafter) should be subject to constant re-examination to determine if they are true and feasible in practice. See WAGNER (1890, translated version), p. 10.

WAGNER (1890, translated version), pp. 13-14.

Ibid. 
Combining fairness and revenue-collection is of special importance if one takes ring-fenced incentives into account. For instance, if companies from abroad are subject to a near-nil tax or a tax holiday (e.g. a set period of time in which no taxes are due) though domestic companies pay a normal tax, then the financial principles would be at risk. One may argue that companies from abroad will receive less in return, but if one would compare a zero tax with the potential benefit of government sponsored infrastructure or the basic education of potential staff a certain unfairness cannot be ruled out. Furthermore, a tax incentive that stimulates only billion-sized investments will lead to a decrease in tax burden for multinational corporations while local enterprises investing in staff and facilities of a relatively small size cannot profit therefrom. Even though the job-increase-to-taxdecrease ratio may be the same, ${ }^{26}$ vertical equity may be at stake as a result of such incentive. The redistribution effect of subsidisation will often be regressive, because only the targeted group will receive aid that is financed by tax revenue levied from the general population (individuals and corporations). As the European Commission considers, for a government to favour enterprises by granting a subsidy taxes must be levied on the rest of the economy. As a result thereof, enterprises in the same Member State not receiving aid are at a disadvantage and pay higher taxes be it directly or indirectly. ${ }^{27}$

Neutrality of taxation - as in non-interference with normal company policy and competitive behaviour - can not be easily combined with the concept of tax incentives. By definition, trade related tax expenditure is not neutral. Such incentives try to stimulate certain behaviour that would not occur under normal market conditions. In my opinion, it is impossible to bring behavioural elements of a tax system within the logic of its primary, classical purpose namely (neutral) revenue collection. Whenever the tax system is used to influence certain behaviour of taxpayers, there will be tension between the instrument used and the nature of the system. One cannot neglect that the concept of neutrality has been consistently infringed during the last decades by using the tax system as an instrument to achieve other policy goals than revenue collection.

\subsubsection{Transparency and Administration}

The collection of revenue should be relatively easy, without causing a disproportionate burden to the tax administration or extreme compliance costs to the tax subject. Regulation should be transparent and understandable in an ideal situation so that every potential beneficiary will be able to make use of it without facing insurmountable difficulties in regard to compliance. Transparent regulation 
will also make it easier for tax administrations to determine when and if an incentive is to be granted and reduce the cost of administration.

Any effort to design tax incentives that comply with supranational subsidy regulations should not be solely focussed on meeting the requirements of these regulations. It is important to look primarily at the transparency of such incentives. The complexity of using the tax system as an instrument for subsidisation makes one wonder whether tax subsidy programs are implemented in practice as they were meant to be. Much depends on the level of expertise of the executive officials of the tax administration and the (advisor of the) taxpayer ${ }^{28}$ The size and level of detail of the regulation embedding tax incentives nowadays require a high level of expertise to make effective use of such incentives. Small enterprises simply cannot afford to pay for such expertise and are often unable to acquire the technical and procedural expertise themselves. As a result thereof, some of them will be forced to abstain from applying for a tax incentive. In general, in the designing of a tax incentive it should be attempted to reduce the taxpayer's compliance costs to a minimum. It should be noted that the issue of complexity does not only play its part in regard to fiscal subsidies. Cash subsidies may also be embedded in a complex regulatory and administrative framework as well.

\subsubsection{Efficiency}

In using tax measures to stimulate certain desirable behaviour by companies and entrepreneurs, one must provide special attention to the issue of economic efficiency. Governments should not interfere as long as the market by itself will perform certain actions. No subsidisation will be necessary to induce investments or actions that are already being made on the basis of normal investment decisions. But if the market cannot do without a subsidy, then such subsidy should be applied as efficient as possible. It must be focused on a certain goal and reach mainly (or preferably only) targeted taxpayers in order to minimise the risk of ineffective loss of tax revenue. The latter could be a result of certain taxpayers gaining access to a tax measure that would not be eligible in a strict sense, thus VERMEEND. As he points out, if one wants to minimise this risk one should abandon the use of fiscal measures. ${ }^{29}$ Governments often try to limit the number of beneficiaries for tax incentives because of budgetary restraints and controllability. Even though resources should be used as efficient as possible under such restraints, we will see that the level of restraint is very important to determine whether a tax incentive will be subject to trade subsidy regulation.

Choosing for fiscal subsidisation instead of providing cash grants and alike should in no way interfere with the requirements that such subsidy regime must fulfil. The level of regulatory detail of tax expenditure should not vary from that of direct expenditure. I agree with SURREY and SUNLEY who see no reason why a government would be satisfied with less stricter conditions for granting a benefit 
when performed by means of the tax regime rather than by direct expenditure. ${ }^{30}$ Even though governments should choose the easiest way to implement a subsidy, regulation must not be stripped of the safeguards necessary to ensure its efficiency. One of the most important safeguards, namely periodical re-evaluation, will be discussed in paragraph 2.5 hereafter.

Apart from economic efficiency, there are also the principles of administrative efficiency, as defined by WAGNER. ${ }^{31}$ One must first be able to determine the actual tax due at all. Doing so should be as convenient as possible. The administrative burden and the collection costs should be held as low as possible. As VERMEEND recalls, tax measures have the benefit that it is not necessary to create revenue first in order to spend it. Moreover, these measures can be implemented as part of an administrative framework that is already in existence. Even then it is necessary that the additional paperwork is minimised to keep additional costs to a minimum. ${ }^{32}$

\subsection{Cash Grants versus Tax Incentives}

\subsubsection{Visibility}

Why do States often prefer to use fiscal incentives rather than other means of subsidisation? DE HOSSON considers that not collecting tax revenue gets less attention than granting a cash subsidy. ${ }^{33}$ In certain Member States it seems to be very hard to determine the level of fiscal subsidisation. On the other hand the total of cash grants is often available - sometimes very detailed - in the national Budgets on the expense side. Likewise, the amount of tax expense could be visualised in the Budget or made otherwise available in order for governments and politicians to see what they got into or should get into. In several states tax expenditure is already included in the annual Budgets in order to visualise such incentives. SUGIN warns for the political implications of providing a list of tax expenditure in a Budget. Unjustified exclusion of tax expenditure from such list (whether or not as the result of lobbying by special-interest groups) could draw away the attention from some kinds of expenditure. Setting a legal or administrative benchmark can be part of the political game in an attempting to reduce the visibility of tax expenditure..$^{34}$

Moreover, in order to get a better insight in the costs and benefits of tax expenditure it could be considered obliging (larger) companies to include the amount of tax subsidisation in their financial statements together with other kinds of government subsidies received. Apart from including direct government subsidisation in cash-flow statements and profit and loss accounts, one should also visualise the amount of cash retained by not having to pay a certain amount of tax.

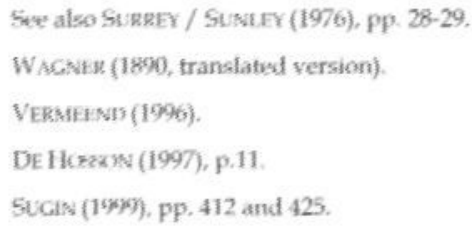


By doing so the tax subsidy can be set off against other forms of government subsidisation, which would facilitate the periodical re-evaluation of a tax subsidy scheme. ${ }^{35}$

The essence of tax expenditure visibility is simple: allowing a reduction in tax for certain taxpayers does not differ from directly granting them cash as far as the use of government resources is concerned. For this reason tax expenditure should get similar political attention as cash subsidisation would get, especially in regard to the periodical review necessary to determine whether tax expenditure (like any other form of government expenditure) is still needed and as efficient as possible. SCHWARTZ and CLEMENTS also call for an increase in transparency of subsidisation. For that purpose they prefer providing subsidies in cash and directly from the Budget. ${ }^{36}$ Even though I agree that subsidies should be visible in the Budget, I do not agree that cash subsidies are to be considered the most transparent solution by definition. I agree with EASSON that a preference of 'cash' subsidies over tax incentives for reasons of transparency is not entirely rational. ${ }^{37}$ Granting an aid in the form of a cash subsidy does not guarantee that such subsidy scheme would be more transparent than the fiscal alternative.

Nevertheless, one cannot deny that embedding a subsidy in a fiscal framework - which is complex by itself - makes it sometimes hard to determine whether tax expenditure is present. ${ }^{38}$ This will make visualisation of tax expenditure not as easy as one would hope for in practice. As SURREY recalled, items of tax expenditure have no special identification mark. The methods used rather resemble the operational aspects of basic structural techniques normally used in income tax systems. ${ }^{39}$

\subsubsection{Confidentiality and Sensitivity}

The fiscal system may be preferred because of the confidentiality surrounding the process of collecting taxes that makes it less suitable for external control, thus DE HossON. ${ }^{40}$ This presupposes that in the matter of cash subsidies the level of confidentiality is not as high as in regard to fiscal subsidies. As mentioned above, if companies are to disclose the amount of subsidy they receive in their financial statements I see no reason why the amount of fiscal subsidies should not also be

See paragraph 2.5, infra, and Buss (2001), p. 101.

SCHWARTZ / CLEMENTS (1999).

EASSON (2001a), p. 366.

The complexity of fiscal law makes it harder to determine whether a certain facility has a specific character, thus DE Hosson (1997), p.11.

SURREY (1973), p. 92.

Even when external control would be possible, supranational bodies like the European Commission are still apprehensive about the sensitivity of Member State when entering the area that the latter regard as their fiscal sovereignty thus DE Hosson (1997), p.11. Chapter III will discuss the more active role the Commission has taken in recent years in regard to fiscal state aids. 
disclosed. As VOGEL recalls, if the effect of behaviour regulating provisions is beneficial to the tax payer then such benefit should be regarded and treated as an independent subsidy, among other to prevent it from escaping (non-fiscal) regulations covering the granting and financing of subsidies. ${ }^{41}$ This would also include disclosure rules from my point of view.

\subsubsection{Ease of Administration}

Another argument in favour of using the fiscal system is that it is often the easiest way to go. Not having to collect taxes in order to spend them on the same group of persons from which they were levied reduces the transaction costs for the administration and the taxpayer and it would often be more convenient for all parties involved. This is a matter of economic and administrative efficiency, be it that the financial advantage of not having to collect and spend will often be a marginal one. SURREY does not agree that the ease of existing procedure and the lesser cost of administrative implementation would favour the use of tax incentives over cash subsidies. In his view,

"[it] is not the tax route that makes the program simple - it is a substantive decision to have a simple program." With a simple program, all that would be needed would be a check-writing process in order to put the subsidy program into effect. ${ }^{42}$

Be that as it may, one psychological aspect should not be disregarded. Taxpayers tend to use all means available to lower their tax debt. In the course of filling out the annual tax assessment, taxpayers will often come across such incentives by themselves or with a little help from some tax planning guides or tax experts. On the other hand, cash subsidy programs must often be applied for, following specific procedure, and without a duly introduction to the general population or the target group it will get not as much attention as a tax incentive would.

\subsubsection{Politics}

The choice between fiscal or cash subsidisation is not only a matter of economics but also of politics. One political argument used in support of tax incentives is that businesses receiving them are more supportive to the political factions that introduced them, while taxpayers funding them are largely unaware of their existence or indifferent.

There is also a tendency among politicians to exaggerate the importance of fiscal benefits to firms when making strategic business decisions. The attractiveness of a tax regime is only one of many factors that play a role in planning economic activities like investments and the establishment of subsidiaries of branches,

\footnotetext{
41 VOGEL (1977), p. 99.

42 SURREY (1973), p. 132.
} 
together with other social and economic conditions, notwithstanding that in some sectors (like the banking, insurance and finance business) fiscal arguments will indeed play a decisive role. Apart from the presence of tax incentives - or cash subsidy schemes for that matter - other factors may be equally or even far more important. Risk will be a key factor for investment decisions and determining suitable locations for industrial facilities or headquarters; political and economical stability tends to be a must for most corporations. The level of wages is also a very important factor, especially in the labour intensive industry. Non-bureaucratic and transparent legislation can be of influence as well as decent legal protection. The presence of a proper infrastructure and of qualified labour can also be a decisive factor.

It must be considered whether tax revenue is better spend when it is not collected in the first place by offering tax incentives or lowering statutory tax rates rather than investing it to improve the factors mentioned in order to make a country more attractive. Regardless of the answer to this question, one cannot deny that tax incentives are of some importance to international trade and business and may have their influence on business performance and transactions throughout the world ${ }^{43}$ Especially in close calls, the tax factor may tip the balance. ${ }^{44}$

\subsubsection{Tax Expenditure as a Policy Instrument}

The opinions on using the tax system for non-fiscal purposes do vary. As SCHÖN points out, selective tax measures are part of the fiscal framework in which States may operate in order to pursue certain general or specific economic aims. The State has several opportunities to pursue economic goals by means of taxation. First, the over-all level of taxation can be reduced. Second, the tax burden may be shifted between taxpayers, for instance by a shift from direct to indirect taxation. One could also think of creating separate tax regimes for corporations, entrepreneurs and other individuals. Third, the tax burden can be reduced or shifted by introducing selective measures (e.g. tax incentives) in order to stimulate investment or to attract corporations and investors from abroad. ${ }^{45}$

VANISTENDAEL (2000, p. 157) argues that fiscal subsidies have little or no effect on corporate decisions of an economic nature. He poses the elementary question why so much political effort is put in fighting such measures when their practical effect is negligible. But according to EAsson (2001a, p. 271), taxation is becoming increasingly important as a factor for investments from abroad in the last couple of years. Thus H. AARON in a discussion during the 'Tax Policy in the European Union' congress in Rotterdam on 18 October, 2001.

SCHŌN (1999), p. 914. Unlike SCHŌN I consider the preferential tax treatment of outbound goods and services or any disincentive to foreign goods and services as part of the third option. This also includes the preferential tax treatment of foreign companies to stimulate their investment or to increase their local activities. 
VERMEEND points out that taxation policy cannot be regarded by itself because of the synergetic effect with other areas of government policy. He stresses that taxation policy forms an integral part of financial and social-economic policy. ${ }^{46} \mathrm{It}$ can thus be argued that tax expenditure is a legitimate instrument to influence social-economic behaviour, which is justified by its purpose.

Yet, SURREY favours replacing most kinds of tax expenditure by direct subsidy program when possible. ${ }^{47}$ FELDSTEIN agrees that not all tax expenditure is appropriate and some tax subsidies should be eliminated, but he turns down the presumption that government spending is better than tax expenditure. ${ }^{48}$ In some cases, it could even be useful to examine whether tax subsidies would be better than current or proposed government spending in certain areas. Even though FELDSTEIN does not want to defend the use of certain kinds of tax expenditures, he stresses that it is important to begin an analysis of current or proposed subsidies without prejudice against the use of tax expenditures. ${ }^{49}$ I agree with FELDSTEIN that using the tax system as a method for subsidisation must not be turned down instantly. However, the use of the tax system demands transparency in order to visualise the tax expenditure cost.

As TIPKE points out, the issue of tax expenditure is more of a technical one. The difference with a normal subsidy is that there is no transfer of funds but a credit against taxes due..$^{50}$ As any subsidy, tax expenditure can be acceptable if it is necessary and suitable for the objective pursued and proportional for its purpose. If there is no better (i.e. more cost efficient and effective) method than using tax measures as a means of subsidisation, than I see no reason still to prefer a cash subsidy to tax expenditure. Critics however argue that tax expenditure favours only a certain group of taxpayers by definition, so equality of taxation could be at issue. In my opinion the issue of equality should not play a part in deciding between a fiscal incentive or a cash subsidy, because it does not make a difference whether a tax reduction is granted to a specific targeted group or a cash grant is provided to that group after first being collected from the general population of taxpayers. However, we must take into consideration that most income tax systems and some corporation tax systems are of a progressive nature. Tax incentives that lower the taxable base will favour those entrepreneurs with higher income more than others. Tax incentives that lower the net tax liability with the same amount for eligible taxpayers (i.e. tax credits) are therefore to be preferred from an equality perspective.

In my opinion, a political decision not to use the tax system as an instrument of subsidisation anymore would deny that tax incentives could be equally effective

VERMEEND (1996).

SURREY (1973), p. 209.

FELDSTEIN (1980), p. 102.

FELDSTEIN (1980), p. 122. He indicates that tax expenditure could be better than government spending in areas like charity, health insurance, retirement savings, the finance of higher education and the support of local public services. 
and more cost efficient than cash grants in certain cases. As long as the costs of tax expenditure are visualised, a reduction in tax could be an alternative for such grants if it is better suited to do the job. However, in their preference for fiscal subsidies politicians should be careful not to make the tax system a too complex matter for those taxpayers that fall outside the scope of such subsidy. Having a really simple tax system may be wishful thinking, but we should be cautious not to make a tax system more difficult than absolutely necessary by introducing extensive and intricate subsidy schemes. Like any other kind of government subsidisation tax expenditure requires an in-depth analysis and discussion about its necessity in the public interest. There should be no easy lane for fast acceptance of tax subsidies in parliament just because a new fiscal year is about to start.

\subsection{Domestic Periodical Review}

In order to strengthen cost control and to safeguard efficiency, periodical review of subsidy schemes is necessary. Bringing a subsidy within the fiscal framework should not make it safe for revision and elimination as a result of periodical reevaluation. BILAL expresses the need for an ex ante as well as an ex post assessment of aids granted by governments. Before granting an aid to address market failure (if any), it must be considered whether there are no other means available that may do the job. If not, then it still has to be considered whether the aid is efficient. After granting the aid one must determine whether the desired result has been achieved and at what costs or why not. ${ }^{51}$ The costs of systematic ex post assessment would only be minimal in comparison to the billions of subsidies granted annually.

In a literature study on tax incentives, Buss listed some recommendations in the field of reviewing fiscal incentives. One recommendation concerns the requirement of a cost-benefit study before introducing tax incentive programs that also looks at economic and social consequences beside of the fiscal ones. Another recommendation is not only to periodically evaluate tax incentive programs, but also to introduce sunset provisions that terminate programs unless they are reauthorised by the legislature. ${ }^{52}$ The latter could draw at least a bit attention to the periodical evaluations, before they disappear in a big pile of paper. I support the introduction of such sunset clause to make sure that fiscal subsidies are properly reevaluated after a certain period of time.

Of special importance is a remark from HOUTHAKKER in regard to the political rationale for periodical review: subsidy programs need attention because political inertia and vested interest created by the subsidy programs tend to preserve such programs long after their initial justification (if indeed there was one) has 
disappeared. ${ }^{53}$ SCHWARTZ and CLEMENTS agree that any subsidy scheme should be subject to regular control (i.e. a periodic reassessment of the rationale for subsidisation) and limited in time, notwithstanding possible renewal after due reconsideration. They stress that subsidy programs should be as explicitly as possible to improve administration and thus to facilitate control..$^{54}$

\subsection{The Need for Supranational Subsidy Regulation}

Subsidies may have cross-border effects in a way that they affect economies of other states. The need for supranational regulation of subsidies cannot be explained by the pursuit of efficient subsidisation within one country, for this is for a large part a national matter. Even though there may be well-founded arguments in favour of subsidisation by a government, such subsidisation may affect international trade. As WISHLADE emphasises, the principal issue of international subsidy regulation is not the distorting effect within the subsidising country but rather the distortion of other economies in the form of import-substitution and export promotion. ${ }^{55}$ This interdependence between economies world-wide make some kind of regulatory limitation on subsidisation a necessity whereas it must be acknowledged that there may be legitimate needs for subsidisation, such as extreme market failure to the extent that minimal welfare levels are endangered. Creating some kind of control mechanism for subsidisation is therefore of a common interest.

The most important cross-border effects of subsidisation will be export stimulation and import substitution. An example:

Companies A and B produce identical widgets at a cost price of 10 Euro. Due to heavy competition between A and B, both are forced to sell their widgets at cost price. Suppose the government of the country in which A resides decides to grant A a subsidy of 5 per widget produced. A will now be able to sell its widget below cost price without making a loss. The country in which B is established does not grant an aid. As to import substitution, in the country of A people will prefer widgets from $A$ rather than the more expensive ones from $B$. As to export stimulation, even people in B's country will be tempted to buy the more cheaper widgets from $A$ instead of those from $B$.

The competitive situation in this example can be restored in one of three ways: either (1) A's country is forced to stop granting a subsidy, or (2) B's country will

H.S. HOUTHAKKER (1972), The control of special benefit programs, in: U.S. Congress Joint Economic Committee, The Economics of Federal Subsidy Programs - A Compendium of Papers, 92nd Congress, 2nd Session, Washington D.C., as summarised and cited by SCHWARTZ and CLEMENTS (1999), p. 132. 
grant a similar subsidy or (3) country B levies an amount equal to the subsidy on each imported unit. In case of option three B's country would be collecting duties in order to keep the prices of widgets in its territory the same between A and B. This however does not prevent that B will lose turnover in country A. In regard to the second option, both countries would be spending money on a subsidy even though there would be no preference by people for either widgets from A or B. The only side effect of the subsidy may be that people are now willing to buy a larger number of widgets because of their lower price, if and when needed. The optimal solution would be for both governments not to grant a subsidy at all, option one. This could be accomplished by mutually agreeing to some kind of subsidy-limiting regulation. ${ }^{56}$

NICOLAIDES and BILAL have brought forward another argument for regulation of subsidies on the supranational level. Rules and institutions on that level are less likely to be influenced by interest groups; national decision-makers can shield themselves by blaming the international institution for not supporting their interests. By adopting supranational regulation, national interventions in the benefit for the often small but political influential groups are restrained. ${ }^{57}$

Trade regulation could prevent a dangerous and harmful cascade effect in the area of tax competition. A tax incentive in one country may attract new corporations into that country's territory causing a loss of tax revenue in another country that by far exceeds the domestic increase in revenue (if any). The government of the other country may be forced also to offer some kind of incentive in order to prevent corporations from leaving its territory. In turn the first country may be forced to introduce additional incentives in an attempt to create the stimulation that was intended initially. Some sort of regulation is necessary to bring a stop to this race, which in the same time should recognise a certain minimum need for rational subsidisation. ${ }^{58}$ I.e. one country should allow another country to grant a limited amount of tax incentives if it serves a purpose they mutually agreed upon, either bilaterally or as part of a multilateral framework like the WTO Subsidies agreement or the EC state aid regime. This will be addressed in-depth in chapters II through V.

Trade regulation should not merely focus on granting subsidies. One of the justifications the Economist gave for granting export subsidies is the need to compensate domestic companies for protectionism abroad. (Going Too Far in Support of Trade, The Economist, 16 December 2000.) Suppose A's country would decide not to levy a subsidy but to impose an import duty of 5 per imported unit of widgets from B, then B would still not be able to meet the price $\mathrm{A}$ is able to set without being forced to make a loss. If subsidies were to be ruled out in international trade though foreign protectionism like levying duties on imports were still to be allowed, the export could still be affected. It is therefore not surprising that subsidy regulation is only a small part of the trade regulation that the EC and the WTO provide for. captured by industrial lobbyists that attempt to introduce or maintain subsidy schemes. (State Aid Scoreboard of 18 July 2001, COM 2001(412) final, p. 30.) 
On the EC level, the granting of aid by individual Member States may be in the interest of the Community as a whole by raising economic prosperity in their less developed regions or by resolving social problems in such regions. However, using aids as a manner to attract businesses from other EC States when there is no market failure - thereby increasing domestic economic welfare at the cost of the welfare abroad and the loss of national state resources - may lead to a decrease in the overall welfare level of the Community. Since it is of importance to prevent such crossborder rent extraction in the Community, the state aid regime may be of help to regulate part of it. The control of state aids within the Common Market cannot be left over to the Member States themselves, although, of course, they have a certain role to play in preventing unacceptable state aids from being granted by any government institution. As Commissioner MONTI recalled,

\footnotetext{
"State aid control can, in essence, only be ultimately performed at the supranational level in order to be efficient, neutral and to avoid a subsidy spiral between Member States" ${ }^{\prime 5}$
}

In the EC the total annual amount of state aids amounts to 89.9 billion Euro. This includes 7.4 billion in fiscal aids and social security reductions $(8.2 \%) .{ }^{60}$ As to indicate the role of fiscal subsidies in international trade, one may look at the tax savings incurred with the US FSC tax scheme. Official estimates indicate that annual tax expenditure on this scheme alone would amount to over 4 billion US\$ in $2001 .^{61}$ The FSC scheme will be discussed in more detail in chapter IV.5.2.

\section{No Immediate Tax Law Influence}

What makes the regulation of government subsidisation most interesting for tax specialist is the fact that it has nothing to do with taxation as such. The tax system is merely used as a method to implement subsidisation, which could often also be

Speech at the Universiteit Nyenrode, 22 January 2002 (no. SPEECH/02/15).

1997-1999 averages. Source: Ninth survey on state aid in the European Union, European Commission, COM 2001(403) final, p. 122. The fiscal data has been derived from groups A2 and C2 as defined in the survey, including fiscal as well as social security reductions. A distinction between fiscal aids in the form of direct tax incentives or indirect tax incentives could not be made on the basis of the data available. It is interesting to see that from the 16.1 billion Euro in regional aid (already included in the aforementioned amount) almost a third, 5.2 billion, was granted in the form of fiscal incentives (32.3\%). (The over-all amount of aid has decreased with about $14 \%$ over the last couple of years. In comparison, the 1993-1995 annual average was about 104 billion Euro.) 
implemented by other means. Even though regimes that regulate (trade) subsidisation reflect on the area of tax incentives, they are not guided by fiscal principles for the most part. The competitive framework in which subsidy regulation is embedded has the effect of turning the fiscal world upside down by scrutinising certain aspects of fiscal systems in the area of tax expenditure, antiavoidance legislation and tax collection procedure.

For the remaining part of this book the reader should keep in mind that the EC state aid regime and the WTO Subsidies Agreement are guided from a competitive point of view, which explains most of the peculiarities in their application within the fiscal system that we will meet hereafter. 
Tax Incentives between Politics and Economics 
Part I

\section{REGULATION OF FISCAL TRADE INCENTIVES}

\section{A Way of Looking at the Benefits of Tax Deferral}

" Do you ask the Congressman if he would blithely let his debtors say they will pay their debts to him some time in the future and

forget about interest or security in the meantime?

Do you ask the Congressman if he would like to know

a bank that would lend him money without an interest charge and without collateral?

Do you then say to the Congressman that some taxpayers are aware of such a bank - they call it the U.S. Treasury?"

S.S. Surrey

Pathways to Tax Reform, 1973 



\section{ASSESSMENT OF FISCAL STATE AIDS WITHIN THE EC}

\section{The Concept of Incompatible State Aid}

\subsection{Article $87(1)$ EC}

The Common Market is a core element of the European Communities. It enables (most) goods and services to be provided freely across the territories of the EC Member States. The state aid regime intends to regulate the granting of financial support by these States to enterprises and entrepreneurs operating within this Common Market. Such support could provide enterprises with a competitive advantage over competitors from other Member States that have to do without it. As set forth in chapter I, financial support could enable enterprises not only to compete with their goods and services at more favourable (subsidised) prices, but it may also just serve to keep them in business. Survival of the most efficient producers is at the basis of free competition, a result of which is that the least efficient companies will eventually be forced off the market. In the pursuit for a unified and free Common Market, government financial support could thus have certain adverse effects on the operating of the market as such.

In order to safeguard the Common Market from the undesirable effects of government financial support on intra-community competition, Articles 87 to 89 of the EC Treaty provide the legal basis for the EC's state aid regime. ${ }^{1}$ In Article $87(1)$ EC the 'prohibition' of state aid is formulated:

"Save as otherwise provided in the Treaty, any aid granted by a Member State or through State resources in any form whatsoever which distorts or threatens to distort competition by favouring certain undertakings or the production of certain goods shall, in so far as it affects trade between Member States, be incompatible with the common market." 
This 'prohibition' in neither absolute nor unconditional as we will see in this chapter. ${ }^{2}$ Paragraphs II.1 to II.3 will first address the definition of state aid from a fiscal perspective and the exceptions to the prohibition. Hereinafter a financial contribution by any level of government will be referred to as 'aid' in an EC context.

When the EC Treaty was signed in 1957 there seems to have been little concern about the relationship between state aids and fiscal benefits or about the impact of the EC Treaty on direct taxation issues in general. But as time has learned, the EC Treaty had a significant effect on direct tax systems all over the Community. EC Member States must exercise their direct taxation powers in consistence with Community law. ${ }^{3}$ By agreeing to supra-national regulation of trade and competition, Member States gave up part of their fiscal sovereignty. ${ }^{4}$ Their national legislation and practices must be brought in line with these regulations, regardless of their fiscal or non-fiscal nature. Even though both direct tax legislation and the implementation of tax arrangements are matters of the fiscal authorities of a Member State, the exercise of their national competence must be in compliance with the Treaty provisions on state aid. ${ }^{5}$

As MCDANIEL argues, it does not matter whether the beneficiary of a subsidy is put into a certain economic position by either a tax benefit or a direct, cash subsidy. If states fail to subject special tax provisions to international trade subsidy regimes like state aid an 'enormous loophole' would be created. ${ }^{6}$ Fact is that financial support can be granted through the fiscal system in the form of tax benefits. Putting

See also ECJ 78-76 of 22 March 1977, Steinike-Weinlig v Germany, ECR 1977, p. 595, paragraph 8. In general, Article 88(3) EC prohibits that new aids or aid schemes are put into effect until such time the Commission decides on what to do with an aid. The Commission may decide that to exempt an aid from the prohibition on the grounds specified in articles $87(2)$ and (3) EC. But until then, the prohibition is still in place. This will be discussed in detail in paragraph II.4 on procedure. ECJ C-264/96 of 16 July 1998, ICI v Colmer, ECR 1998, I-4695, paragraph 19.

Without elaborating on the subject, several association agreements - providing the conditions for association of third countries with the EC (among other in regard to access to the Common Market and economic support) - impose on those countries a prohibition that is similar to article $87(1)$ EC. Any practices contrary to that prohibition will be assessed on the basis of the criteria arising from the application of article $87 \mathrm{EC}$ and the case law of the ECJ and the CFI. (See, for instance, the Europe Agreement establishing an association between the EC and its Member States and Poland, OJ L 348/2 of 31 December 1993, article 63; cf. Hungary, OJ L 347/2 of 31 December 1993, article 62. Also see the procedural implementing rules referred to in footnote 238, infra. For an exception to the normal application of these criteria, see footnote 158, infra.) Thus, the scope of state aid control may extend its influence to other territories than those of the EC Member States. 
limitations on granting support in cash without blocking the fiscal alternative simultaneously would merely lead to a shift from cash to fiscal benefits. It is not the form of an aid that is important, but its effect. With this in mind, the European Court of Justice (hereinafter: the ECJ) ruled that the mere fact that aid is provided in the form of a fiscal aid does not exclude that aid from Article 87(1) EC and the state aid regime; ${ }^{7}$ to that extent fiscal sovereignty is limited.

In order to determine whether a tax measure comes within the scope of the state aid definition, its four elements will now be discussed. From the outset, it should be kept in mind that in order for a tax measure to be considered state aid all elements of the definition must be fulfilled. Some elements may be met relatively simple, without necessarily indicating that a tax measure will turn out to be state aid in the end.

\subsection{Element 1: The Presence of a Benefit}

\subsubsection{Tax Expenditure}

Some kind of financial benefit should be conferred to the beneficiary (i.e. the recipient) of a 'state aid'. The determination of a benefit in regard to fiscal aids is for the most part based on the concept of tax expenditure addressed in chapter I. ${ }^{8}$ The ECJ ruled that apart from positive state action like subsidies, aid can also result in a negative sense by not creating tax liability in the first place or by not collecting tax debts once a liability was created. ${ }^{9} \mathrm{~A}$ benefit thus exists in case there is a diversion from the normative tax regime. The European Commission (hereinafter: the Commission) has given some guidelines on how the state aid rules will be applied to tax incentives that relate to direct business taxation in a 1998 notice. ${ }^{10}$ This notice provides an overview of some of the most frequent tax incentives: ${ }^{11}$

"a reduction in the tax base (such as special deductions, special or accelerated depreciation arrangements or the entering of reserves on the balance sheet; a total or partial reduction in the amount of tax

EC] 173/73 of 2 June 1974, Italy v Commission, ECR 1974, 709, paragraph 13.

See also MCDANIEL (2001), p. 1638.

ECJ 30/59 of 23 February 1961, Gezamenlijke Steenkolenmijnen in Limburg v High Authority of the ECSC, ECR 1961, 1; C-387/92 of 15 March 1994, Banco Exterio de Espãna, ECR 1994, 1-877, paragraph 14; ECJ C200/97 of 1 December 1998, Ecotrade v AFS, ECR 1998, 1-7907, paragraph 34; C-6/97 of 19 May 1999, Italy v Commission, ECR 1999, 1-2981, paragraph 15-16; C-53/00 of 22 November 2001, Ferring v ACOSS, ECR 2001, 1-9067, paragraph 15.

Commission notice on the application of the state aid rules to measures relating to direct business taxation, OJ C $384 / 3$ of 10 December 1998 (hereinafter: the 1998 notice).

Ibid., paragraph 9. 
(such as an exemption or a tax credit); deferment, cancellation or even special rescheduling of tax debt."

It may need no further explanation that a reduction in taxes that are normally borne by companies and entrepreneurs will lead to a benefit for these taxpayers. It does not matter whether an aid exists on a permanent rather than a provisional basis in order to determine the presence of a benefit. ${ }^{12}$ The benefit can be a one-time only event (such as a tax credit) or a (semi-)continuous one (such as tax deferral) as we will see next. We will take a closer look at certain peculiarities of the different methods of operation of tax expenditure as defined by SURREY in relation to the element of 'benefit'.

\subsubsection{Income Exclusion/Transfer Pricing (1)}

Excluding certain income from the tax base may result in a reduction of the tax burden. Whether such exclusion can be considered a benefit for state aid purposes is another matter. This will depend on whether the exclusion is part of the normative tax system or not. For instance, excluding foreign income from the national tax base is a normative matter if we assume that a Member State uses a strictly territorial tax regime (i.e. it taxes profits or income to the extent that it arises from activities that take place within its territory). There will be no benefit if no tax is due on income that is not subject to tax anyway (i.e. there is no relief from taxes normally borne). Since the issue of the normative tax regime coincides with the element of benefit as well as that of specificity, I have decided to address this issue further in paragraph 1.5 , infra.

Transfer pricing is of special interest in regard to exclusion of income from the tax base. A commonly used standard to determine the price of goods and services transferred to or delivered to related companies is the 'at arm's length' principle. It provides that related companies (for instance, two companies that have the same owner) should charge prices equal to those unrelated companies would use. This is necessary in order to allocate the profit on a transaction to the correct enterprise. ${ }^{13}$ It will normally require a case-by-case assessment in order to take the peculiarities of a given transaction into account. ${ }^{14}$

If a Member State uses the 'at arm's length' principle to determine proper transfer prices, the incidental setting of a price that is below an 'at arm's length' level could result in a benefit. I.e. there could be partial non-taxation of profit 
normally attributable to activities of a company within the Member State concerned. If the company is the taxable subject, it will then receive a benefit. For a concern as a whole it may be that total taxation will remain the same within a Member State in case of transactions between related companies within that Member State, but in case there are cross-border transactions there will normally be a benefit for the concern as a whole. Even if we would presume that the State where the receiving enterprise resides would tax the remaining profit - which it will not when the latter State determines the transfer price correctly - there still remains a fiscal benefit in the first Member State. This national benefit is decisive for state aid purposes. ${ }^{15}$

Finding the proper transfer price can be a difficult matter. Sometimes there is a so-called 'comparable uncontrolled price', a price used by unrelated companies in (nearly) identical transaction, but often there is no such price. A price must then be determined by using one of several alternative methods. ${ }^{16}$ As for the so-called costplus method the Commission held:

"The cost plus method is an alternative method of taxation, which is normally aimed at overcoming the difficulty of assessing cross-border commercial transactions between companies belonging to a same group and at limiting the scope for avoiding tax. In the cost plus method, the taxable profit is obtained by applying on all the expenses (the cost) incurred [...] a margin (the cost plus) expressed in percentage. Although this method of taxation does not constitute state aid per se, its practical application can give rise to State aid, for example when certain expenses are not taken into consideration for the determination of the taxable profit or by applying an inappropriately low margin."17

The general objective of the cost plus method and other methods is to find a price that would best match an at arm's length price on the basis of the (economic) data available and the circumstances of the case. It seems that the Commission is willing to grant the tax authorities at least some leverage in trying to determine a proper transfer price, because it seems satisfied that the price determined should lead to a level of taxation that is 'equal or at least comparable' to that in case of unrelated

There will even be less taxes paid over-all in case the effective tax burden in the latter state is lower than that in the first mentioned state. This however is not of interest from a state aid perspective.

The Commission tends to accept the methods set forth in the OECD's 1995 Transfer Pricing Guidelines for Multinational Enterprises and Tax Administrations as suitable methods to determine a proper transfer price. (See the Commission's invitation to submit comments concerning German control and coordination centres of foreign companies, OJ C 304 of 30 October 2001, p. 3.) 
transactions. ${ }^{18}$ Even so, a company should still be able to substantiate that a certain transfer price, as agreed with the tax inspectors, reflects normal profit allocation as well as possible because the use of a profit margin that is too low or the exclusion of certain costs from the calculation of the tax base - such as financial costs - could produce a benefit. ${ }^{19}$

In practice enterprises will be allowed to operate within a price range that acts as a safe haven; prices within that range will be considered at arm's length. This kind of flexibility is necessary in order not to overload the tax authorities with numerous requests to approve of price adjustments resulting from normal market volatility. To what extent the Commission is willing to accept such arrangements is yet unclear. The setting of extremely permissible ranges could provide for some difficulty from a state aid perspective when prices in the outer limits cannot reasonably be assumed to be at arm's length anymore. This could thus lead to a benefit for the taxpayer concerned. Of course, the Commission will have a hard time to produce the necessary quantitative and statistical evidence to back this up. Also, it is current practice that transfer pricing agreements are concluded for a number of consecutive years for tax planning purposes. In the absence of a possibility for interim review that would allow the tax inspector to divert from such agreement in case a change in facts or legislation would warrant an adjustment in profit allocation, there would also be the chance of a (future) benefit. ${ }^{20}$

\subsubsection{Tax Deferral}

The benefit from a tax deferral - like the creation of fiscal reserves - is to be found in the financial advantage; there is no need to find means to finance a tax payment right away. This leads to a more favourable position on liquid assets and the interest benefit resulting therefrom, either from savings or from not having to borrow financial means elsewhere until it becomes necessary to pay the deferred tax..$^{21}$ Deferral will not qualify as a benefit if appropriate interest charges are levied. In case the pay off of a debt to a business creditor is postponed, there will normally be compensation for the delay in the form of interest. If there would also be a similar interest due on the deferred amount of tax, then there would be no benefit since there would be no difference between postponing a commercial loan or a tax debt.

See the Commission's invitation to submit comments concerning Luxembourg coordination centres, OJ C 304 of 30 October 2001, p. 11; italics added by the author.

Commission press release IP/02/1236 of 26 August 2002 (Biscaye coordination centre regime); italics added by the author.

Also see the Commission's invitation to submit comments concerning the Belgian coordination centre regime, OJ C 147 of 20 June 2002, p. 2, paragraph 46.

See among other the Commission's letter published in OJ C 354 of 9.12 .2000 concerning the opening of a formal investigation into some competitive aspects of the Dutch 'vamil-regeling', pp. 2-11, paragraph 15. 
In order to determine what level of interest would be appropriate, the Tubacex case may be of help.22 The tax authorities do not need to set a level that results in a profit from the deferral - as private banks would do - but they should charge the interest that a private creditor would charge that seeks to recover at least part of the sums due to it by agreeing to some kind of repayment scheme (either by rescheduling the payment or by paying in instalments). A private bank would normally charge a higher interest on loans than the private creditor, since in the latter case the obligation to repay is already in existence. ${ }^{23}$ If no private creditor would allow any delay because no interest charge would be near sufficient to compensate for the risk of non-payment, then the tax authorities should also try to save what can be saved at once. Not doing so could lead to a benefit since no private party would be willing to grant any extension of payment considering the financial circumstances the recipient is in. ${ }^{24}$ Even if private creditors are willing to grant an extension of payment, the public creditor should still not extend more in relative amount and in time than its private counterparts would do.

\subsubsection{Flexible Depreciation}

Flexible depreciation can lead to a temporal tax benefit. An example:

Suppose we have an asset of 100.000 Euro with an economic lifetime of 10 years. After that period its residual value is 10.000 Euro. The normal depreciation method is linear depreciation. In case of linear depreciation the annually deductible depreciation costs will amount to $(100.000-10.000) / 10=9.000$ Euro. But now, the government decides to allow enterprises to choose for a more flexible depreciation scheme for certain assets. Under such scheme, the taxpayer may determine himself the period in which he will write-off his assets. In case the taxpayer would now choose to write-off the asset at once, he would be able to deduct 90.000 Euro in the first year. The taxpayer would thus be able to pay far less taxes in the first year since he has 81.000 Euro additional depreciation costs. At a marginal tax rate of $30 \%$ this would lead to a saving in taxes of 24.300 Euro. This amount can be put into a savings account and raise interest. In years 2 till 10 the taxpayer will have to pay more taxes since he will not be able to deduct 9.000 Euro annually. At $30 \%$ he would be paying 2.700 Euro more each year. This additional amount of tax can be withdrawn each year from the savings account. After 10 years, the deducted amount will be 90.000 Euro in

EC) C-342/96 of 29 April 1999, Spain v Commission (Tubacex), ECR 1999, I-2459.

The role of this private creditor test in fiscal cases is limited, except for the purpose of determining the appropriate interest rate. Since no other private person or entity exists that can order and enforce tax payment, the test can not be used to determine the core benefit itself.

ECJ C-256/ 97 of 29 June 1999, DMT, ECR 1999, I-3913. 
either case and the supposed savings account will be empty, apart from accrued interest.

If certain assets - like aeroplanes or ships - may be depreciated in a more flexible way then this may benefit companies using such assets, even though nominal depreciation costs will match that of normal depreciation in the long run. The Commission points out that such flexibility may lead to the allocation of taxable income over time at the discretion of the company. This could result in a benefit if one takes net present value differences in total tax payments into consideration. ${ }^{25}$ To put it simple: the interest raised by being able to put the tax saved in year 1 into a savings account for a certain period of time is considered to be a benefit to the taxpayer.

I do not agree with the Commission that there needs to be a presumption of aid when tax authorities have a certain freedom to set different depreciation periods or different valuation methods on a firm by firm or a sector by sector basis. ${ }^{26}$ If sector-specific characteristics or the specific circumstances of a firm require the use of shorter periods or special valuation methods to reflect the present residual value of an asset best there is not necessarily an element of benefit. However, should the authorities allow for different periods or methods in (near) identical cases there could indeed be a benefit.

One should look at the general system that is used to determine depreciation periods and valuation methods. If the general rule is that a fiscal balance should give a prudent view of a firm's financial status, it is understandable that it will be necessary to fit periods and methods to the specific characteristics of each sector. On the basis of economic considerations it is common policy to depreciate certain assets faster than others depending on their economic life span; a computer may have a lifespan of merely 3 years while real estate may have an economic lifespan of 20 years or more. However, in those sectors where plants are used very intensively such lifespan may be reduced to 10 or 15 years.

The use of other methods than linear depreciation is not unusual, since certain assets loose much of their value in the first years in which they are operated and have far less value in the end. For example: a new car that has been used for a few months will have lost much of its value simply for being a 'used car'; the difference in value between a 7 or 8 year old car will be far less. Also think of the new interior of an office that looses much of its glance after being used even for a short time. Writing off more in the beginning would therefore not be inappropriate from an economic point of view. Yet, the writing off of any asset at once or in a period far shorter than its economic lifespan will probably not reflect the asset's present residual value properly in most cases. This could thus result in a fiscal benefit when accelerated depreciation is not generally available in a given tax system. of 20 June 1996. 


\subsubsection{Insolvency (1)/Remitting Tax Debt ${ }^{27}$}

A failure of a government to protect its interest by preventing future losses in taxes may constitute a benefit. For instance, a benefit may be present when the Member State does not take the legal measures available to it as a creditor under its insolvency legislation in order to prohibit that a bankrupt company continues its business although it is known that it will not be able to comply with its tax and social security obligations. ${ }^{28}$ Keeping a company in business against one's better judgement could thus be regarded a benefit. Even when there is no (threat of) insolvency, a failure by the tax authorities to collect tax debts in accordance with normal procedures could constitute a benefit. ${ }^{29}$ The remitting of tax debt for instance will be considered to be a benefit of course, since taxes due do not have to be paid anymore.

\subsection{6. 'Negative Aids' (1) ${ }^{30}$}

In order to determine the presence of a benefit in fiscal matters it is important to find a proper benchmark, i.e. the normal regime upon which the tax payable is to be calculated. Determining the benchmark will be extremely difficult when certain corporations are confronted with an additional tax burden (a 'tax penalty'). One could think of applying higher tax rates to certain sectors of industry while using the same taxable base as other sectors. If the benchmark would be the normal rate, then obviously no benefit will result from the extra tax burden. However, if we consider the higher rate to be the benchmark this would lead to the assumption that all other corporations and sectors would be receiving some kind of benefit. From an economic point of view, in order to create a difference in tax burden it would not matter whether the State lowers the over-all tax rate for all companies but few or whether it would raise it for only a few. The relative difference created between companies will be equal. ${ }^{31}$ An example:

This paragraph merely focuses on the issue of benefit. Refer to paragraph 1.5.10, infra, for the specificity element in regard to insolvency procedures. Decision 91/144/EEC of 2 May 1990, OJ L 73/27 of 20 March 1991; Notice C20/92, OJ C 247/2 of 10 September 1993.

30 BACON has first used the term negative aid in discussing a similar English case concerning indirect differential taxation of insurance premiums. In this so-called Lunn Poly case the level of insurance premium tax was higher for insurance policies concluded at travel agencies than for insurances concluded at other agencies. It was at issue whether there was an aid to all sectors but one. See BACON (1999), p. 387. 
If one sector of industry would be subject to a lower rate of tax the matter is obvious. But if 10 sectors out of 20 would be allowed to use a lower tax rate, the matter becomes blurred. Would it be 19 out of 20 then we pity the sector that is left with the higher rate of tax, but we will not consider all other sectors to have been granted a benefit. Vice versa, if we would raise the tax rate for one sector of industry it will be pitied for not getting the standard rate. In case 10 sectors out of 20 would be subjected to a higher rate, again the matter becomes blurred. In case 19 sectors out of 20 would, then the last sector allowed to use the 'standard' rate would be considered lucky for receiving this kind of benefit.

The above seem to be a non-issue at present from a state aid point of view. But what about the future? Could someone call for an examination of the decision of a Member State to impose a higher corporate tax rate - still using the general tax base - on sectors like the automotive industry and cigarette industry for ecological or public health reasons? The evolution of taxation in Western Europe in the last decennia of the 20th century shows that apart from the purpose of collecting tax revenue the fiscal system is more and more being used as an instrument for social and environmental purposes. One cannot predict how the use of the fiscal system as a government instrument will evolve in the 21st century. The heart of the matter is that without being able to determine a proper benchmark, one cannot determine whether tax expenditures are present. If this distinction cannot be made, it is neither possible to determine the presence of a benefit.

\subsubsection{Expenses and Marginal Tax Rates}

Until now we have talked about benefits in general without considering the fact that the net amount of a tax benefit may well vary from the initial benefit granted as a result of the functioning of the fiscal system. For those readers who are familiar with taxation this matter will be self-evident. Some examples:

As a result of the general nature of taxation, excluding certain sources of income from the tax base will normally block the deduction of any costs directly or indirectly related to that non-taxable source. ${ }^{32}$ For instance, if gross export income is excluded from the tax base the net benefit will not be the gross income times the applicable tax rate but it should be lowered by the non-deductibility of export related costs. ${ }^{33}$

See also MCDANIEL. / SURREY (1985), p. 11.

Some tax schemes do explicitly allow the deduction of costs (losses), even though the source of income (profit) to which they are connected is excluded from the tax base. The benefit of such halfway exclusion can be substantially larger than that of full, net exclusion that does not allow for such deduction. In case of a halfway exclusion it should be considered that although the exclusion in itself may considered not to 
Thus exempting 100 Euro in gross export income from the tax base at a $50 \%$ rate will not lead to a benefit of 50 in case export related cost amount to 40 . The net benefit will only be 30 Euro based on net export income. ${ }^{34}$

Some general tax deductions for business expenses may be determined as a fixed percentage of total taxable business income without the need to provided evidence. Excluding certain business income from the tax base could have an impact on the size of this proportional deduction. For instance, in order to stimulate selfemployment there will be a tax incentive in the form of a reduction of taxable entrepreneurial income by $10 \%$ with a maximum of 5.000 Euro. Suppose an entrepreneur has such income to the amount of 50.000 Euro. He could thus apply for the full 5.000 Euro reduction. The entrepreneur is also eligible for another tax incentive that allows him to exclude half of his export income from the tax base. If he had had 20.000 Euro in export income, then income would be 30.000 Euro. As a result he would merely be entitled to a reduction of 3.000 Euro. The net-benefit will therefore not be 20.000 times the applicable tax rate, but 20.000 minus 2.000 times that rate.

Of course, the net benefit of a tax base reduction to entrepreneurs may also vary in case of a progressive tax rate scheme. Reducing the tax base from 1000 to 500 will result in a benefit of 125 at a $25 \%$ tax rate and a benefit of 250 at a $50 \%$ tax rate.

\subsubsection{Foreign Tax Regimes as a Benchmark}

When determining the size of any advantage one could argue that the tax regime in third countries might play their part in determining the benchmark. Corporations may decide to move business activities abroad in order to profit from a more favourable tax regime there. In order to prevent such move, a State may feel urged to create a tax incentive in order to keep such corporations within their territory. This puts up the question of the proper benchmark.

The benefit can be determined in one of two ways. Either one compares the regime in one and the same Member State before and after the tax incentive, which would by definition lead to some kind of benefit. On the other hand, one can compare the new domestic tax position and the tax position that would have occurred if activities had been moved abroad in case the domestic tax incentive had not been introduced. From a tax planning point of view, this is a very interesting matter. However, it is a dangerous discussion from a state aid point of view.

contain a benefit (such as the exclusion of foreign income using the concept of territorial taxation), a remaining deduction (such as the inclusion of foreign start up losses contrary to the chosen concept) still might

Net income $(100-40=60)$ times $50 \%=30$ Euro. 
If a Member State would be allowed to introduce any tax incentive necessary to keep corporations from moving into a territory with a more favourable tax regime, then it could be claimed that such incentive does not contain any benefit for that corporation because it could get an even larger benefit abroad. Apart from the fact that this reasoning would favour a fiscal race to the bottom, it cannot be denied that on the domestic level these corporations will be better off with the incentive than without it (compared to the amount of tax normally due). This is still the comparison that is to be made to determine whether there is a benefit or not.

In my opinion, excluding this kind of incentive from the state aid prohibition would severely limit the impact of the state aid regime. Even though policy considerations like trying to keep companies from leaving are legit, taking part in the game of creating tax incentives should not solve these problems. As the ECJ held it is not the aim of a tax incentive that determines whether it is aid, but its effect..$^{35}$ The mere objective of a measure to bring (tax) charges in a specific sector in line with those in other Member States can not alter the conclusion that such measure contains a benefit; it is the reduction in tax that is decisive and not the size of tax burden to which it relates. ${ }^{36}$

\subsubsection{Article 86(2) EC: General Economic Interest}

Article 86(2) EC provides that undertakings that are entrusted with the operation of services of general economic interest or those that have the character of a revenueproducing monopoly are subject to among other the rules of competition as set forth in the Treaty, insofar as their application does not obstruct the performance of the particular task assigned to that undertaking. One could think of postal services, the supply of energy or waste management. The status of a service of general economic interest may not affect the development of trade to such an extent as would be contrary to the interest of the Community. Member States may define such services of general interest, subject to Community supervision for manifest errors. It is not necessary that the aid is granted merely to one single public company with exclusive rights; it may also be granted to a number of companies responsible for providing a certain service, regardless of it being public or private. In any case, one or more undertakings must be entrusted with a service by or on behalf of a public authority, either by act or agreement.

Article 86(2) EC needs to be interpreted very restrictively. ${ }^{37}$ The aid granted must be proportional; it may not exceed the net extra costs of the service provided. ${ }^{38}$

Commission held that Article 86(2) EC serves as a last resort to escape from the state aid prohibition in case none of the derogations provided in Article $87 \mathrm{EC}$ would apply (OJ C 17/4 of 19 January 2001, paragraph 26). However, it follows from the ECJ's November 2001 Ferring case (to be discussed hereafter) that a 
For instance, if a contract is closed with a waste management firm to collect waste even in the farthest corners of a country the contractor will make additional costs (like transport and personnel cost) to collect waste that other contractors would not even consider to collect. A financial contribution by the government that would be limited to these additional costs would be considered proportional. The latter is of special importance in regard to service providers that also provide services other than those qualified as being of general interest; disproportional aids could reflect on the competitive position of the provider in regard to those other services. ${ }^{39}$ The Member State must therefore arrange for the beneficiary to maintain a separate set of accounts in regard to the service of general economic interest in order to get a transparent view of the costs involved with that activity. ${ }^{40}$ An example:

\begin{abstract}
The French undertaking 'La Poste' was entitled to a series of tax advantages that applied to all of its activities. ${ }^{41}$ La Poste was entrusted with the management of a series of services of general economic interest, including the obligation to maintain a postal presence in rural areas and insurance services. La Poste is competing with other service providers when it comes to insurance. Even though the tax advantages included the insurance activities, the overall amount of the tax benefit was lower than the additional costs of the public service activities. The Court of First Instance (hereinafter: the "CFI") therefore upheld the Commission's decision that the aid scheme could be approved under Article 86(2) EC.
\end{abstract}

In the Ferring case - one of the few indirect tax cases I will discuss - there was an exemption of sales tax for wholesale distributors of pharmaceutical products that were under a duty of public service to deliver to pharmacists and certain other organisations in order to guarantee the short-term supply of a wide range of medicinal products in a certain area; such duty was not imposed on other

financial benefit would not meet the fourth element of state aid at all and would therefore be outside the scope of the prohibition. It thus would not be in need of an exemption anymore.

See Commission communication COM/2000/0580 final. A fixed amount of aid for a certain period of time is allowed, if determined by transparent and non-discriminating standards. In regard to proportionality, it may not be held that the enterprise providing the service of general economic interest could work more efficient in order to reduce costs and thus the aid necessary in the absence of Community rules covering this issue. (CFI T-106/95 of 27 February 1997, FFSA and Others v Commission, ECR 1997, II-229, paragraph 108.)

See HANCHER (1998).

Transparency directive, article $3 \mathrm{a}$. This requirement does not apply to small undertakings and those that were entrusted with the service on the basis of an open tender (article 4(2)). 
distributors such as pharmaceutical laboratories that produced their own products. The ECJ ruled that

"provided there is the necessary equivalence between the exemption and the additional costs incurred, wholesale distributors will not be enjoying any real advantage for the purpose of Article [87(1) EC], because the only effect of the tax will be to put distributors and laboratories on an equal competitive footing". ${ }^{42}$

In case the amount in taxes saved would have exceeded the additional costs borne in discharging public service obligations, the part of the advantage exceeding those costs would not be covered by article 86(2) EC and would have been considered state aid. ${ }^{43}$ Thus as long as the fiscal benefit does not exceed the cost disadvantage of performing a service of general economic interest the first element of the state aid definition will not be fulfilled.

\subsection{Element 2: Aid that is granted by a Member State or through State Resources in any Form Whatsoever}

\subsection{1. 'State' Resources}

In order to fulfil the second element the aid should be financed by a Member State or through State resources. ${ }^{44}$ When it comes to tax measures, this relationship is relatively easy to determine. The lesser a tax subject has to pay the lesser the State's tax revenue will be. Because of this relationship, it is not of importance how a tax benefit is created. It may be embedded in tax legislation or regulation or it may be the result of practices of the tax authority. ${ }^{45}$ The word 'state' also includes more decentralised bodies. As far as regions or municipalities have some sort of tax jurisdiction, they also may be in a position to grant tax incentives such as reductions in property taxes for certain kinds of property where entrepreneurial activities take place.

Ibid., paragraphs $30-33$.

The direct or indirect use of state resources is necessary for the application of the state aid regime. Other benefits transferred by the state by means of legislation - without involving the use of state recourses - do not fall within the state aid regime. See ECJ C-379/98 of 13 March 2001, Preussen Elektra v Sleswag, ECR 2001, 1-2099, paragraphs 59-62. In this case, the state obliged energy suppliers to buy a certain amount of environmentally friendly electricity from certain suppliers at a fixed minimum rate. The higher rate was fully financed out of private resources.

1998 notice, paragraph 10. 


\subsubsection{The Intent to Transfer Resources}

The question may arise whether the government must have the intention to transfer of a benefit out of state resources. The term 'aid' does have a connotation of an 'intention to help', i.e. to provide assistance deliberately. A tax benefit could be the mere result of an unintended error in judgement or a simple mistake like an error in writing at the part of the tax authorities. EVANS considers that an unintentional adoption of wrongful valuation for tax assessment purposes in the benefit of the taxpayer may not constitute aid, unlike in case of an intentional and persistent misapplication. ${ }^{46}$

I respectfully disagree with EVANS in this regard. If one would argue that a financial benefit out of an unintended misapplication of tax law is not to be qualified as aid, then this would be hard to reconcile with the concept of state aid. The notion of 'aid' is an objective one: the presence and the effect of an aid is decisive, ${ }^{47}$ not its raison d'être. ${ }^{48}$ The tax authorities' unawareness of the presence of a benefit cannot be detrimental to the existence of the benefit itself and the effects that it may have on intra-community competition. ${ }^{49}$ Looking at the second element in itself, the transfer of resources - the reduction in tax liability - is evident, even if the reduction itself is the result of a simple mistake.

A decrease in revenues may be the inherent result of the introduction of new legal obligations by the state, without such obligations being a means to transfer financial resources.

For instance, in the Sloman Neptun case the law covering working conditions and minimum wage rates did not apply to certain seafarers. Even though there may be a potential loss of tax revenue due to the setting of wages below minimum levels, this consequence is "inherent in the system and are not a means of granting a particular advantage" to the shipping corporations concerned..$^{50}$ In the Preussen

Evans (1997) pp. 34-35.

See also paragraph 1.1, supra.

See ECJ 310/85 of 24 February 1987, Deufil v Commission, ECR 1987, p. 901, paragraph 8, and ECJ C$382 / 99$ of 13 June 2002, The Netherlands v Commission, not yet published, paragraph 61. Of course, the Member State's intentions and motives to grant a certain aid may still play their part when it has to be determined whether the aid should be exempt from the state aid prohibition (i.e. be declared compatible). This will be addressed in depth in paragraph 2 , infra.

To my mind, when the purpose of the regime is incapable of preventing a measure from being qualified as state aid, the absence of such purpose can neither. See CFI joined cases T-92/00 and T-103/00 of 6 March 2002, Territorio Histórico de Álava and Others v Commission (Ramondín), not yet published, paragraph 51.

ECJ Joined Cases C-72/91 and C-73/91 of 17 March 1993, Sloman Neptun v Seebetriebsrat, ECR 1993, I887, paragraph 21. 
Elektra case, the ECJ considered that even though an obligation to purchase renewable energy at minimum prices (higher than the real economic value of such energy) will have a negative impact on the economic results of an undertaking, the subsequent diminution in (direct) tax receipts is inherent to such legislative provision. This cannot be regarded as a means of providing an advantage to producers of such energy at the State's expense. ${ }^{51}$

\subsubsection{Indirect Transfers}

State resources do not have to be transferred directly to the beneficiary. Fiscal benefits that influence the decisions of consumers and private investors may indirectly result in a financial benefit to a specific sector of industry; a triangular construction. ${ }^{52}$ In the cases below tax revenue was sacrificed in order to influence the behaviour of third parties to the benefit of certain companies.

In the 'Fonds Industriel de Modernisation' case France granted a tax exemption for interest on special savings accounts to individuals. ${ }^{53}$ These savings were then used to finance loans to certain industrial projects at an advantageous interest rate. Even though the benefit was granted to the individuals, the companies involved in the industrial projects indirectly profited from the tax exemption.

Another case concerned $\$ 52(8)$ of the German Einkommensteuergesetz. ${ }^{54}$ It provided that as from 1996 up to $100 \%$ of any capital gain resulting from the sale of assets or shares in companies may be set off against acquisition or production costs provided that the gain is used to acquire shares - either by an increase in capital or the establishment of a new company - in companies that have their office and central administration in one of the new Länder or the Western part of Berlin and that have no more than 250 employees at the time of acquisition. ${ }^{55}$ This resulted in an increased demand for shares in such companies. As a result of the tax scheme, share buyers can acquire

EC] C-379/98 of 13 March 2001, PreussenElektra v Sleswag, ECR 2001, 1-2099, paragraph 62.

See also Mederer (1999), pp. 1859-1860; Koschyk (1999), pp. 135-140; Koenig/Sander (2000). Contra, Frick (1994), pp. 51-52 and 68. As we will see in paragraph 2.2, infra, Article 87(2)(a) provides for an explicit exemption from the state aid prohibition for social aids granted to consumers. This presupposes that such aids come within the scope of the state aid prohibition initially.

Decision 85/378/EEC of 19 December 1984, OJ L 216 of 13 August 1985, pp. 12-19 and ECJ 102/87 of 13 July 1988, France v Commission, ECR 1988, I-4082.

Decision 98/476/EC of 21 January 1998, OJ L 212 of 30 July 1998, pp. 50-57.

It is also allowed to acquire shares from holding companies that have as their objective to acquire shares in the companies mentioned above. 
shares at more favourable terms than they would have without the scheme (if they had done so at all). Investing in the capital of companies within the regions mentioned has thus become more attractive. The Commission concluded that even though the economic advantage is not passed on by any public or private body, it follows that the passing on of the advantage from the change in investment behaviour of private share purchasers to certain companies is caused by the relevant legislative provisions and is thus attributable to and caused by the State. The ECJ concurred:56

\begin{abstract}
"The fact that investors [...] take independent decisions does not mean that the connection between the tax concession and the advantage given to the undertakings in question has been eliminated since, in economic terms, the alteration of the market conditions which gives rise to the advantage is the consequence of the public authorities' loss of tax revenue. [...] It follows that the Commission was right to consider that the tax concession entailed a transfer of State resources."
\end{abstract}

The third case concerned Dutch mining companies. It was determined that allowing a bonus to be paid tax free to miners conferred a benefit. This tax facility would make such underground work more attractive and would offset threatening departures. This indirect stimulation of recruiting does confer a benefit since other mining companies would have to bear all labour costs themselves, ${ }^{57}$ such as the higher gross wages needed to meet the net wages of the subsidised mining companies.

The Commission followed a similar line of reasoning in regard to a Danish $25 \%$ flat rate income tax for experts recruited abroad. It turned out not to be state aid eventually. ${ }^{58}$ reason not to approve the aid was that the need for the companies invested in to have their seat within the specified region infringed upon articles 43 and 48 EC. Corporations having their seat in other Member States would not be eligible for the benefit when establishing a branch or alike within the region, without proper justification (ibid., paragraph 85 ). See also chapter III.3. 


\subsubsection{An Over-all Burden on State Resources}

Although the element of affecting state resources seems to be straightforward when it comes to tax measures, it may still give raise to debate. A simplified description of the Technolease case may serve as an example. ${ }^{59}$

Philips agreed to a sale and leaseback contract concerning know how with its subsidiary Electrologica. This subsidiary was then sold to Rabobank. This transaction resulted in a shift of taxable profit between the Philips fiscal group and the Rabobank fiscal group. Philips received 640 million NLG for the transaction in cash. As a result of this transaction, taxable profit of Philips increased and that of Rabobank decreased in the following years because of the 'transfer' of the opportunity to write off the know-how. The Dutch tax authorities approved of this construction.

The issue at hand was whether the tax authorities only selectively allowed a construction where know-how could be part of a sale and leaseback construction where the lessor would be able to write off that know-how. The Commission determined that this was not the case, i.e. the element of specificity was not fulfilled. However, the most important aspect of this case was first revealed in the press release announcing the Commission's decision that the technolease was no state aid. It said:

\footnotetext{
"From the Dutch State's perspective, the shift in taxable profit between Philips and Rabobank due to techolease results merely in a shift of tax revenues over time without posing a burden to state resources. In the absence of any payment of loss of revenue by the State the technolease scheme cannot nationally constitute State aid". ${ }^{60}$
}

In the official text of the decision - published 20 months later - it was calculated that the Technolease scheme resulted in extra revenue in total of approximately 31 million Euro due to timing differences in tax payment. ${ }^{61}$ It was concluded that the second element (a grant out of state resources) was not fulfilled either.

I wonder whether the Commission's reasoning was correct in regard to this second element. ${ }^{6}$ In my opinion, it is necessary to look at the tax consequences per enterprise, not at the overall consequences for total tax debt. Suppose we have the following situation, under the assumption that the element of selectivity would 
have been fulfilled (for instance, presume that the tax authorities' prior approval of a sale and leaseback construction is necessary and such approval is granted only to $\mathrm{X}$ and $\mathrm{Y})$ :

\begin{abstract}
$\mathrm{X}$ is the seller and lessee and $\mathrm{Y}$ is the buyer and lessor. $\mathrm{X}$ and $\mathrm{Y}$ agree to provide $\mathrm{X}$ with instant cash by getting into a sale and lease back construction. One of the financial motives for $Y$ to get into such transaction - apart from the royalty on the lease back - would be its opportunity to write off the know-how for tax purposes. For $\mathrm{X}$ it would mean an increase in tax liability since it cannot write off the know-how any more, but the benefit from the improved cash position weighs up to such increase. Even though an economic motive may be present, the profitability of the scheme for both parties stands or falls with the discretionary approval of the tax authorities. Without such approval, there would not have been a deal. If $\mathrm{Y}$ would not have been allowed to write off the know-how, the royalty payment would have been so high that it would not weigh up to the temporary improvement of $X^{\prime}$ s cash position. ${ }^{63}$
\end{abstract}

The approval of the sale and lease back construction would be an incentive for $\mathrm{Y}$ to participate in a financing construction that it would never have participated in without the fiscal benefit (presuming that the royalty payment would remain the same). The fact that the overall tax liability of $X$ and $Y$ taken together does not change or even increases cannot be detrimental to the fact that $X$ received a cash-flow benefit because of the state's approval of the tax measure. $X$ received a benefit that is the result of a reduction of $Y^{\prime}$ 's tax liability (i.e. the grant out of state resources). This is a kind of indirect benefit that should be put on a par with those discussed in paragraph 1.3.3, supra. ${ }^{64}$

VISSER also opposed to the Commission's methodology, but for another reason. He argued that if a fiscal aid scheme would lead to the establishment of foreign corporations in the granting state, total tax revenue may rise when such corporations would make a profit and would actually pay certain taxes. In such case, there would be no use of resources since revenue would increase provided that corporations already established in that Member States cannot profit from the same aid scheme to the extent that their reduction in tax would supersede the extra income. are only at risk of being qualified as state aids when they are not normally allowed under national tax law, but rather approved of (or tolerated) in individual cases. This issue of selectivity will be addressed in detail in paragraph 1.5, infra. 
revenue from the newly established corporations. ${ }^{65}$ In my opinion the application of an overall burden test would be detrimental to the functioning of the system of state aid control in cases like these. In a recently published case, the Commission does indeed seem to reconsider the issue of over-all tax revenue for determining the actual use of state resources. It considered:

"[the] fact that, overall, an aid scheme increases the number or the amount of taxable operations and therefore creates additional revenue for the State is not relevant" in the context of determining whether an "advantage is granted by forgoing tax revenues, i.e. through State resources". ${ }^{66}$

\subsection{5. 'Negative Aids' (2)}

In regard to the issue of 'negative aids', the second element of the state aid definition is unlikely to be fulfilled if only a small number of sectors are affected. Increasing the tax base for only a few sectors of industry will lead to an increase in revenue instead of expenditure out of state resources. This seems to be implicitly confirmed by the CFI. Should a certain taxpayer be subject to higher taxation than its competitors by mistake, it cannot be argued that the competitors taxed in accordance with tax law provisions received state aid. Such an error in application of tax law would only lead to an increase in revenues instead of a transfer of resources, thus the CFI. ${ }^{67}$

\subsection{Element 3: Aid that distorts or threatens to distort Competition and affects Trade between Member States}

The rationale for the intervention by the Community in the field of state aids is expressed in the third element. Cross-border competition and trade within the common market should be affected - actually or potentially - by an aid in one way or another. ${ }^{68}$ This requirement is rather easily fulfilled in practice. ${ }^{69}$ To meet the

VISSER (2000a), p. 847.

Decision of 11 December 2001, OJ L 184 of 13 July 2002, p. 27, paragraph 42. Emphasis added by the author.

CFI T-613/97 of 14 December 2000, Ufex and Others v Commission, ECR 2000, II-4055, paragraph 117. In this case the benchmark could be properly determined since - except for the mistake made - the competitors would have been taxed similarly. There was no actual 'negative aid' scheme involved here.

In a pending case concerning the French Centrales de trésorie regime, the Commission took the position that, at first sight, trade seems affected in case it is required that companies must be operating in a multinational setting to be eligible for a special tax regime. (OJ C 302/8 of 27 October 2001). Also see the decision opening the formal investigation into Dutch Finance Activities regime, OJ C 306/7 of 31 October 2001 (pending). 
third element it is sufficient when an aid 'threatens' to distort competition and is 'capable' of having an impact on intracommunity trade. ${ }^{70}$ When an aid strengthens the competitive position of an undertaking in comparison with its intra-Community competitors, intra-Community trade is deemed to be affected. ${ }^{71}$

Corporations that profit from aid may be able to sell their products and services in another Member State at a more attractive price than the corporations in that other State. ${ }^{72}$ But not only outbound trade may be affected, also inbound trade. Aid to companies that do not carry out export activities themselves may still affect intra-community competition. These companies might be able to maintain or increase their domestic production or to sell their products at a more favourable price, thereby making export from other Member States to the domestic market more difficult or less competitive. ${ }^{73}$

One might argue that tax incentives conditioned exclusively upon non-EC export would be outside the scope of the state aid prohibition. However, the ECJ interprets the concept of distortion very widely and decided that the competitive benefit outside the EC resulting from state aid may also positively affect the competitive position of the benefiting corporation within the Community. ${ }^{74}$

In order to determine whether there is distortion of competition the Commission not only focusses on the market the aid recipient is in. Suppose we have a coordination centre that handles loans and other financial affairs for a group of companies. A tax exemption for that centre may also be of benefit to those other companies, because they often pay less for the getting their loans (besides economies of scale). In order for the coordination centre to reach the same profitafter-tax margin without the incentive, there should have been a higher profit mark

See also two pending cases concerning Gibraltarian corporation tax incentives. The Commission took the preliminary position that competition and trade will be affected because "the qualifying company may not, in normal circumstances, trade or carry on business in Gibraltar, with Gibraltarians or residents of Gibraltar." This would thus leave no other parties to do business with than those outside Gibraltar. (OJ C 26/9 of 30 January 2002, paragraph 14; OJ C 26/13 of 30 January 2002, paragraph 29.) CFI T-195/01 and T-207/01 of 30 April 2002, Gibraltar v Commission, not yet published, paragraph 125. ECJ 730/79 of 17 September 1980, Philip Morris Holland BV v Commission, ECR 1980, 2671, paragraph 11; 1998 notice, paragraph 11. The Commission is not required to demonstrate the real effect of an aid introduced without its approval. (ECJ C-301/87 of 14 February 1990, France v Commission, ECR 1990, I307 paragraph 33.)

In the decision opening the formal investigation into a tax incentive for French headquarters and logistics centres, the Commission held that because of the requirement that these headquarters and centres should mainly provide services to establishments of a group outside France, it could not be ruled out that intracommunity trade is affected. See OC C $302 / 2$ of 27 October 2001 (pending). 
up to compensate for the costs of intermediation and alike. Those other companies may thus be a co-beneficiary of the benefit, which could cause distortion in competition in their relevant markets. ${ }^{75}$

Should a distortion be limited to the national level, then the state aid regime would not apply. This kind of distortion is to be taken care of by the national governments themselves, based on the principle of subsidiarity. The manner in which the Member State deals with mere internal competition is not the concern of the Community as long as it does not affect intra-community competition and trade in one way or another. But what kind of tax incentive would not affect competition and trade within the common market? Maybe incentives that are merely available to small local-operating businesses like to grocers and butchers, since it is unlikely that a supplier from another country will be competing in that area. However, this will not be true when it comes to a supermarket in a border area when its most important competitor is only a few metres and an antique border sign away. The local nature of business activity in itself will therefore not suffice to conclude that an effect on intra-community trade is absent. ${ }^{76}$

VERMEEND argued that it does not suffice merely to look at tax rates and tax exemptions to determine whether competition is affected or trade distorted. The final result in the form of effective tax burdens should be decisive, thus VERMEEND. 7 The main issue he implicitly addresses is whether the introduction of a tax incentive distorts competition if it would adjust the fiscal burden of a taxpayer to that of competing tax payers in other Member States. Even though taking account of the effective tax burden is a valid argument from an economic point of view to determine distortion of competition, it is not to be of influence on the state aid definition. As we have just seen in paragraph 1.2.8, the objective to bring the effective tax burden for certain sectors in line with the effective burden abroad cannot alter the conclusion that any measure doing so may still be considered state aid. In order to determine whether competition is distorted, "the point of departure must necessarily be the competitive position existing within the common market before the adoption of the measure". The existing competitive equilibrium in the

See the Commission's invitation to submit comments concerning the Belgian coordination centre regime, OJ C 147 of 20 June 2002, p. 2, paragraphs 57 and 65.

For instance, in the tourism sector local activities may still attract a large number of cross-border tourists, depending on its nature and fame. If intra-community tourist flows are attracted, the element of affecting trade between Member States could be fulfilled. See the Commission's letter in case C 42/2001 of 20 June 2001, OJ C $300 / 2$ of 26 October 2001 (pending).

VERMEEND (1998), p. 155. It should also be considered that certain countries have taxes that others have not, thus VERMEEND. This will especially be of importance in relation to certain environmental taxes (ibid.). A reduction of such taxes is often used in order to preserve the competitiveness of resident companies. Even with a reduction, the beneficiary will probably not be in a more favourable position than its competitors abroad compared to the situation in which the environmental tax never existed. 
Community may be distorted if the tax burden (as part of the cost of production) would be reduced for only a given sector of the economy, thus the ECJ.78

As the Commission's 1998 notice emphasises, neither the fact the benefit from a tax incentive is relatively small in amount nor the fact that the recipient is moderate in size or its share of the Community market is very small would prevent the incentive from fulfilling the third element, ${ }^{79}$ especially in sectors where there is already a structural over-capacity or heavy competition by a large number of small companies. ${ }^{80}$ The actual size of a distortion is not relevant to determine whether there is 'state aid' once it occurs, but it is of importance when weighing it off against the extent to which aid is to be exempt from the prohibition. ${ }^{81}$ However, the Commission does take the position that most aids up to 100,000 Euro on a threeyear basis do not fulfil the third requirement. This controversy will be addressed in paragraph 3.2, infra, concerning de minimis aids.

\subsection{Element 4: Aid that favours Certain Undertakings or the Production of Certain Goods}

\subsubsection{Selectivity and Economic Activity}

The fourth element concerns the selectivity of a tax measure (also commonly referred to as 'specificity'); its favourable effect should be restricted - in law or in fact - to one undertaking or a group of undertakings or to the production of certain goods. This is the most difficult, restrictive and in the same time the most vague part of the state aid definition when it comes to applying it in the field of tax incentives. Governments often try to limit the number of beneficiaries for tax incentives because of budgetary restraints and controllability. Although these are valid considerations from a fiscal point of view, they may nevertheless be the trigger for application of the state aid regime by creating selectivity. The following paragraphs give an overview of a number of factors that may lead to selectivity of fiscal measures.

ECJ 173/73 of 2 June 1974, Italy v Commission, ECR 1974, 709, paragraph 17. For the record, a general tax reduction would also have alter the equilibrium but it would not fall within the state aid definition because of failing to fulfil the fourth element of selectivity discussed in paragraph II.1.5, infra.

1998 notice, paragraph 1 . I deliberately excluded the de minimis exemption referred to in the notice. This issue will be addressed in paragraph 3.2, infra.. See also ECJ C-142/87 of 21 March 1990, Belgium v Commission, ECR 1987, I-959, paragraph 43; CFI T-214/95 of 30 April 1998, Vlaams Gewest v Commission, ECR 1998, II-717, paragraph 49. 
Apart from the need for selectivity, the fourth element also reveals that the beneficiary should be a natural person or a legal entity that is engaged in economic activity ('undertaking'). This also follows from the placement of the state aid articles itself, namely in the 'Competition' chapter of the EC Treaty. Non-profit organisations and individuals (not being entrepreneurs or self-employed persons) are thus able to benefit from state aid, without being subject to Article 87(1) EC. However, one cannot exclude that such aid affects some of their activities that have a commercial counterpart. In such a case an economic activity may be present. An example:

Italy provided among other a $50 \%$ reduction of company income tax to banking foundations and a tax exemption on the sale of their holdings in banks. The Commission considered that managing one's own assets and using the proceeds to donate funds to non-profit entities is not to be considered an economic activity. There was thus no competitive advantage. This was ensured by the fact that specific legislation was in place to prevent that banking foundations would exercise banking activities (through controlled banks). The Commission emphasised that in the event economic activities would be carried out by a banking foundation, there could still be state aid (if the other elements are also fulfilled of course) ${ }^{82}$

\subsubsection{General Measures and}

\section{the 'Nature or General Scheme' of the Tax System}

A 'general' tax measure should in principle have the potential of being applicable to all undertakings and sectors of industry. In its 1998 notice the Commission provides examples of general tax measures. It names technical measures, such as the setting of a general rate of taxation, issuing general depreciation and loss carry-over rules, and provisions to prevent double taxation. On the other hand, it defines measures pursuing general policy objectives, such as tax measures to promote research \& development, environmental protection and training of staff. ${ }^{83}$ The notice quite rightly emphasises that some firms or sectors may benefit more than others from a tax measure without such measure being caught by state aid rules. Of course, tax incentives to reduce the cost of labour will benefit labour-intensive industries more than others. So will investment incentives in R\&D or training benefit only those corporations that are willing to undertake such investment. ${ }^{84}$ However, if R\&D incentives were only to be made available to certain sectors of industry there would legislation referred to prevents joint control of banks by banking foundations and regulates the incompatibility of managing positions. 
be specificity. The Commission also points out that industrial investment policy objectives are not peculiar to tax systems and are therefore no inherent part of tax system. ${ }^{85}$

But even if a certain tax measure is not of a general nature, the state aid regime will not be triggered instantly should the other elements of the state aid definition have been met. The ECJ ruled that a (partial) exemption of firms in a particular sector from charges arising from the normal application of the general (tax) system constitutes state aid when there is no justification for this exemption on the basis of the nature or general scheme of the tax system. ${ }^{86}$ At this point I want to stress that the issue of fitting within the 'general scheme and nature' of the tax system is discussed in literature as part of the element of selectivity. However, it also affects the element of benefit. Should a tax measure fit within the general scheme of the system we should ask ourselves whether there is a benefit at all because it would be part of the normative tax system. Yet, since the issue of selectivity plays its part in determining what is the norm and what is not, I decided to address this issue in this section on selectivity.

Certain differences in taxation may be justified because of their necessity for the functioning and efficiency of the tax system, i.e. for "reasons relating to the logic of the system" ${ }^{187}$ If the nature or general scheme of such system justifies a tax measure, then it is considered not to meet the element of selectivity. ${ }^{88}$ "This is usually reflected in the fact that such measures are not applied solely to specific sectors, are based on objective and horizontal criteria or conditions, and are not limited in time", thus the Commission. ${ }^{89}$

The Commission considers the determination of tax on a fixed base in the agricultural sector justifiable if this takes account of special accounting requirements or the importance of land in assets in this sector. Also, specific provisions on the taxation of SMEs may be justifiable from the redistributive purpose of a tax, just like a progressive profit tax scale..$^{90}$ The CFI agreed. ${ }^{91}$ Technical measures to overcome double taxation such as exemptions and deductions are also justified by their technical nature,,$^{92}$ unless they are granted only to certain corporations, goods or sectors in particular. The fact that only those corporations with certain income taxed

87 ECJ C-53/00 of 22 November 2001, Ferring v ACOSS, ECR 2001, 1-9067, paragraph 17.

88 ECJ C-143/99 of 8 November 2001, Adria-Wien Pipeline and Others v Finanzlandes-direktion für Kärnten, ECR 2001, 1-8365, paragraph 42.

89 Decision 96/369/EC of 13 March 1996 concerning fiscal aid given to German airlines in the form of a depreciation facility, OJ L146 of 20 June 1996, pp. 42-48, paragraph V.

901998 notice, loc. cit., paragraphs $23-27$.

91 CFI joined cases T-92/00 and T-103/00 of 6 March 2002, Territorio Histórico de Álava and Others v Commission (Ramondin), not yet published, paragraph 60. 
abroad will be eligible for such measures is inherent to the fact that double taxation would otherwise not occur; it does not cause selectivity by its nature. ${ }^{93}$ An exemption of co-operative entities could also be justifiable by the tax system's nature when tax is levied at the level of its members instead as if it were transparent. ${ }^{94}$ In my opinion taxing incorporated and non-incorporated enterprises differently could also be considered the result of the general system of taxation, when a Member State would decide to subject their profit to a corporation tax or a personal income tax respectively that each have their own set of rules to determine taxable profit.

The Commission emphasises that the purpose of a tax system is to finance state expenditure. From this point of view, it is inherent that Member States take into account that each firm should pay taxes over its profits only once, so that taxes paid abroad should be taken into account in determining domestic tax liability. However, some manners in which this is done are difficult to justify by the logic and purpose of a tax system. The Commission provides the examples of favourable tax treatment of non-resident companies or the granting of tax benefits to head offices or to firms providing intra-group (financial) services. It considers these schemes not to be justifiable as part of the nature or general scheme of the system of revenue raising. ${ }^{95}$ Similarly, a lower corporate tax rate for non-resident companies and resident companies that are fully foreign-owned would bring about selectivity. This seems not to be justified by the logic of the tax system in the Commission's view, because these companies would be treated more favourably than (partially) domestic-owned resident companies. ${ }^{96}$

In the pending case concerning an Irish tax scheme for double tax relief the Commission did not rule out selectivity because the criteria to obtain the certificate needed to get the relief were unclear to the Commission. A tax exemption would be granted of dividends or profits paid to parents in Ireland by foreign subsidiaries, as well as an exemption on capital gains arising in those branches, provided that the parent would submit and carry out an investment plan to create at least 40 jobs or to maintain the employment level in Ireland (by trading operations to be carried out by foreign branches or subsidiaries). If the parent does not fulfil the criteria, the normal tax credit would be granted for the purpose of double tax avoidance. The provisional findings of the Commission indicated that it found that the tax authorities had a still unclear discretionary power in evaluating a proposed investment plan aimed at maintaining employment. Therefore, it opened a formal procedure for detailed analysis. See OJ C 308/2 of 1 November 2001.

1998 notice, paragraph 25 .

1998 notice, paragraph 26. If certain services would be considered common to most enterprises in a Member State, a favourable tax regime for such services would not necessarily be selective in my opinion. However, intra-group financial services seem to occur mostly in larger corporations and are not common to smaller sized groups. 
The problem of determining whether a provision that provides a tax payer with a benefit is justified by relying on the nature or general scheme of the tax system is similar to determining whether a tax measure is part of the normative revenue raising framework or not. This issue has already been addressed in chapter I.2 in order to determine the presence of tax expenditure. In my opinion, we should not try to interpret the meaning of the 'nature or general scheme of the system' in the broadest sense possible. It merely reflects the attempt to create a backdoor for leaving inherent, normative aspects of a tax system outside the state aid regime when they are in danger of looking 'suspicious' for creating some kind of normative diversity. ${ }^{97}$

At first sight, there seems to be no objective justification for a specific measure that would otherwise be justifiable for having a purpose that fits within the internal logic of the tax system, if a more general measure could have accomplished the same objective ${ }^{98}$ I.e. a tax measure should be as less selective as possible while meeting its legitimate purpose. For instance, it has been argued that when a Member States stimulates investments - using tax holidays that are only available to new enterprises capable of making large investments ${ }^{99}$ - and it succeeds in attracting such enterprises, it will secure an increase in future tax revenue because these enterprises become taxable in that State. The CFI held that, should the increase in tax revenue have been the actual purpose of the investment tax incentives, these incentives would still not be justifiable by the nature and general scheme of the tax system because a general tax measure could also have accomplished an increase in revenue. 100

WOUTERS expresses his concern that the definition of what is and what is not state aid should not be generalised. He argues that the test of 'nature or general scheme of the system' is not well suited to handle fiscal cases. He proposes that the criteria causing selectivity must be objective and reasonable in comparison to their purpose. Of course, criteria should definitely not have the intention of giving a competitive advantage to certain enterprises or sectors of economy. Most important, the selective character of an aid scheme should not be theorised too much. It should rather be analysed by its effect on competitive relations from the perspective of the

regard to a Gibraltarian corporation tax exemption, OJ C 26/13 of 30 January 2002, paragraphs 15-16 (pending).

97 See chapter I.2.2.

98 See also A-G Pergola's Opinion of 12 November 1998 in case ECJ C-75/97 of 17 June 1999, Belgium v Commission (Maribel bis/ter), ECR 1999, 1-3671, paragraph 8.

99 See the Basque incentives to be discussed in paragraph II.1.5.5.

100 CFI joined cases T-92/00 and T-103/00 of 6 March 2002, Territorio Histórico de Álava and Others v Commission (Ramondin), not yet published, paragraph 62. It is yet unclear what kind of general incentive the CFI was referring to; I expect this to be a general investment tax incentive available to all new companies, including the smaller ones with less financial means, because they too are likely to become taxable after a certain period of time. 
internal market. ${ }^{101} \mathrm{I}$ do agree with WOUTERS that the test used by the Commission and the Court does not always give sufficient guidance, especially not in regard to fiscal incentives. But analysing the selective character on the basis of its competitive effect would disregard the fact that the competitive effect is a separate element contained in the state aid definition and cannot be decisive as to determine whether a certain level of selectivity is justifiable.

\subsubsection{Discretionary Powers ${ }^{102}$}

The possibility to exercise discretionary powers without being bound to objective criteria indicates the selectivity of a measure. ${ }^{103}$ The 1998 notice clearly stresses that

"Every discretionary decision of the administration that departs from the general tax rules to the benefit of individual undertakings in principle leads to the presumption of state aid and must be analysed in detail." 104

This conclusion is not altered by the fact that legal provisions explicitly provide for such discretionary powers or that discretion is exercised in practice without a legal basis, except that in the latter case the national parliament may have something to look into. Thus the possibility to exercise discretion is sufficient to presume specificity. ${ }^{105}$

In principle, there is no selectivity (nor discretion) if a company has to apply for a certain tax scheme when the application is subsequently approved upon fulfilment of certain objective criteria stated in law or regulations. ${ }^{106}$ There will

WOUTERS (2001)

Unlike other parts of administrative law the discretionary powers of the tax administration are very limited (see also Happé 1996, pp. 9-10), at least they should be regarding the nature of taxation and its purpose to collect revenue on a neutral basis. For the sake of completeness I still address the issue here briefly.

1998 notice, paragraph 24; ECJ C-241/94 of 26 September 1996, France v Commission (Kimberly Clark Sopalin), ECR 1996, 1-4551, paragraphs 23-24.

1998 notice, paragraph 22.

CFI joined cases T-92/00 and T-103/00 of 6 March 2002, Territorio Histórico de Álava and Others v Commission (Ramondín), not yet published, paragraph 35.

One needs to be careful in concluding that granting the application on the basis of the fulfilment of objective criteria does make a scheme general. It is necessary to assess the nature of these 'objective' criteria. For instance, one of the conditions for the Belgian coordination centre regime that is under investigation by the Commission is that the coordination centre belongs to an important and multinational group. This condition would exclude groups that are either less important (i.e. smaller groups) or active in the domestic market only. This seems not in line with the concept of creating fiscal reserves, especially 
neither be selectivity if such approval is granted in advance (an 'advanced ruling') on the provision that all the criteria will be fulfilled and properly verified by the tax authorities afterwards. The legal document stating such criteria should be made available to the authorities and to the taxpayer for verification. For instance, when there is a system to allow postponement of tax payments to corporations or entrepreneurs that are in a severe financial crisis, such postponement should be granted automatically once the tax authorities determine that certain objective criteria have been fulfilled. If the authorities still have some latitute that enables it to grant postponement if objective criteria are not met (or not to grant it when these criteria are met) then such postponement would not be considered a general measure. ${ }^{107}$ The same would be true if the authorities could change or choose the 'objective' conditions for postponement - or even the remittance of tax debt for that matter - as they seem fit. ${ }^{108}$

\subsubsection{Transfer Pricing (2)}

Tax authorities often have some latitude to determine transfer prices. Although a transfer pricing ruling that merely serves to give an interpretation of general tax rules would not be state aid as such, any 'room to manoeuvre' for the tax authorities could - in theory - lead to specificity. ${ }^{109}$ If we presume that national law would (merely) provide that these prices are to be set 'at arm's length', the de facto application of this rule may arouse concern. If it turns out that a transfer price in a transfer pricing agreement with the tax authorities was not set at arm's length, then this would give rise to selectivity. ${ }^{110}$

considering the fact that smaller groups will probably be less capable of dealing with financial risks. In an extensive comment, HINNEKENS (2000) argues that specificity may also be based on the fact that the benefit of the regime is limited to head offices or financial service providers within a group.

107 It the tax authorities could refuse postponement when tax fraud is suspected it would probably not lead to selectivity provided that this exception is not used to categorically exclude certain types of businesses. Of course, any suspicion must be backed up by sufficient evidence that is to be set off against objective standards itself.

Also see ECJ C-256/97 of 29 June 1999, DMT, ECR 1999, 1-3913, paragraph 27.

1091998 notice, paragraph 22.

110 Notwithstanding that transfer-pricing issues are most likely to escape the attention of the Commission if no one informs the Commission of improper transfer pricing decisions. 


\subsubsection{Selectivity in Size}

Size may also be a criterion for selectivity. ${ }^{111}$ Limiting the benefit of a tax provision to large (groups of) companies is considered sufficient to fulfil the selectivity criterion. ${ }^{112}$ Some Spanish aid schemes may serve as an example.

New companies in the Basque Provinces Álava, Guipúzcoa and Vizcaya were entitled to a reduction in their tax base of $99 \%$ phased down to $25 \%$ in the first four fiscal years after establishment. There were three requirements: a paid-in capital of more than 120,202 Euro, minimum-investment of 480,810 Euro and the creation more than 10 jobs. The Commission considered this scheme to be selective because of the investment and job creation requirements. ${ }^{113} \mathrm{~A}$ four-year tax holiday of $50 \%$ for newly established corporations in Nevarre was also deemed specific, because corporations that did not meet the

In the pending investigation into the Dutch financing companies regime (the 'CFM regime'), the Commission argues that requiring a certain size in the form of a geographical distribution of activities over several countries and/or continents can cause selectivity. See OJ C 306/6 of 31 October 2001. It took a similar position in pending cases concerning the French Centrales de trésorie regime, OJ C $302 / 8$ of 27 October 2001 and the Belgian coordination centre regime, OJ C 147/2 of 20 June 2002.

Commissioner MONT at the Universiteit Nyenrode, 22 January 2002 (SPEECH/02/15). I would like to recall that even though tax benefits for large companies may fulfil the state aid definition, this does not make them necessarily incompatible.

The Commission opened a formal investigation procedure into these three schemes mentioned above and concluded that they contained incompatible aids. (Decision on schemes C 49/99, C 50/99 and C 52/99 of 29 September 1999, published in OJ C 55 of 26 February 2000, OJ C 55/2 of 26 February 2000.) For the record, since the three provinces have each a certain form of autonomy, the tax holiday scheme formally consists of three independent (but almost identical) legal schemes. The "tax holiday" aid schemes as the Commission calls the 99 to $25 \%$ reduction schemes - i.e, the same system used by all three provinces were regarded to be prohibited operating aid. These three schemes did not comply with the Community rules on regional aid. (See press release IP/01/981 of 11 July 2001 and, as for the Guipúzcoa regime, OJ L174 of 4 July 2002, p. 31.) In Decision 2000/795/EC of 22 December 1999 the Commission eventually approved of this aid as regional investment aid for the company Ramondin. (OJ L 318/36 of 16 December 2000.) A preceding "tax holiday" scheme used in all three Basque provinces contained a $100 \%$ tax holiday for a period of ten consecutive years as from the year of start-up. It also used the investment and job creation criteria mentioned above. This scheme was also declared incompatible. (See the decision to open a formal investigation into schemes C 58/2000, 59/2000 and 60/2000, OJ C 37/38 of 3 February 2001 and press release IP/01/1875 of 20 December 2001.) 
minimum-investment requirement of 600,000 Euro and the job creation requirement of 10 were not eligible. ${ }^{114}$

Another scheme of the three aforementioned Basque provinces concerned a 45 percent tax credit for corporations that invest at least (about) 15 million Euro. Since the credit is available only to corporations that invest large sums, the Commission regards the scheme to be selective. ${ }^{115}$

In regard to the aforementioned Basque tax incentives, the CFI most recently confirmed that reserving tax benefits for companies with substantial financial means entitled the Commission to qualify such regime as specific. ${ }^{116}$

\subsubsection{Sector Specificity}

A classic case of - in my opinion mistaken - selectivity concerned the fiscalisation of employer contributions to a sickness insurance scheme for employees in Italy. ${ }^{117}$

Employer contributions were cut for males (24,500 Lira a month) as well as females (up to 64,000 Lira). The Commission was of opinion that there was specificity because the larger cut for women benefited certain Italian products, namely those produced with a high percentage of female workers such as textile, clothing, shoes and leather. In these sectors the percentage of female workers was $70 \%$ compared to $25 \%$ in other sectors. ${ }^{118}$

Decision to open a formal investigation into scheme C 51/99, OJ C 340/52 of 27 November 1999; press release IP/01/981 of 11 July 2001.

The $45 \%$ tax credit schemes were declared incompatible because they contained investment aid that did not meet the guidelines on regional aids and aids to SMEs. (See the decision to open a formal investigation into schemes C 53/99 and C 54/99 of 17 August 1999, published in OJ C 351/29 of 4 December 1999; decision on scheme C 48/99, OJ C 71/8 of 11 March 2000; press release IP/01/981 of 11 July 2001.)

CFI joined cases T-92/00 and T-103/00 of 6 March 2002, Territorio Histórico de Álava and Others v Commission (Ramondin), not yet published, paragraph 39 and 49 . The need to exempt aids that are reserved for small and medium sized enterprises (SMEs) from the state aid prohibition provides an indication that such aids fall within the scope of that definition (see paragraph II.3.4, infra). This was confirmed by the CFI in its aforementioned judgement, paragraph 40 .

118 Back then the Commission seemed willing to accept a temporary sectoral restriction of the cut in contributions as part of a major reform of the Italian social security system if it had not been for the sectoral specificity caused by the increased benefit for females: "Because of budgetary constraints this operation would have to be implemented gradually, it had not initially been possible to extend the present system to the whole economy, and that system had had to be confined to industrial undertakings and certain 
I wonder whether nowadays this scheme would still be considered selective. A scheme benefiting the employers of women cannot be deemed selective just because some sectors employ more female workers than others. This difference between sectors results from general socio-economic development of the position of females within the labour population. However, when a scheme specifically lowers employer contributions for manual workers for enterprises that are active in one of the sectors most exposed to international competition then specificity would be present on the sectoral level since other sectors cannot profit from such scheme. ${ }^{119}$ Specificity would be lacking if the scheme would not be restricted to the most exposed sectors, even though some sectors would be able to profit more than others depending on the intensity of manual labour usage. ${ }^{120}$ In some cases it is not clear beforehand whether a certain tax benefit will be sector-specific:

On 3 May 2000 the Commission approved a Danish tax scheme that provided for a $25 \%$ flat rate income tax for experts recruited abroad. ${ }^{121}$ Initially the Commission was of the opinion that the scheme contained state aid in 1992, since it had the potential of benefiting only some sectors. The de facto use of the scheme however showed that it was applied in all sectors and by large companies as well as SMEs; it was therefore considered not to be specific.

A Swedish scheme granting a $25 \%$ reduction of taxable income to foreign experts and a $25 \%$ reduction of the basis for calculating social security contributions to their employers was neither regarded to be specific. Not only because the law did not contain any provision that

undertakings in the services sector." "By excluding certain branches of economic activity from its scope of application, the present scheme as described above may well lose its general nature [...]. However, considering that it forms part of a general reform aimed at eventually extending the system to all branches of the italian economy, the Commission recognizes that implementation by stages may be necessary and that the present scheme is already sufficiently general in nature since it is being applied to the whole of industry." (Decision 80/932/EEC, loc. cit.; italics added by the author). In principle, a sector-specific reduction in employer contributions is of a selective nature. (ECJ 173/73 of 2 July 1974, Italy v Commission, ECR 1974, 709.)

ECJ C-75/97 of 17 June 1999, Belgium v Commission (Maribel bis/ter), ECR 1999, I-3671.

Decision of 25 March 1997 (Maribel quater), OJ C 201/6 of 1 July 1997. The Belgian Maribel quater regime contained a reduction in employer social security contributions that was in part variable depending on the intensity of employment of manual workers in terms of total work force. Taking account of the Commission's 1980 Italy decision, Bourgeois (1999, pp. 773-774) points out that the Commission could well have decided that the Maribel quater regime contained sector specific aid, because "in certain Belgian industrial sectors the employment of manual workers is significantly higher than such employment in Belgian industry as a whole". 
would limit the eligibility of the scheme but also because the Danish scheme proved that such schemes in general were not sectorspecific. ${ }^{122}$

In scarce cases a reduction of the tax burden may be sector specific without coming into the scope of the state aid regime. For instance, the abolishment of minimum wages requirements in a specific sector may result in a decrease in the tax base for wage taxes arising from that sector if wages drop. In a system where the employer must pay taxes on top of net wages or social security premiums in proportion to net wages payment, the potential reduction in tax burden on the side of the employer is inherent to lifting the minimum-ceiling on wages. The ECJ considered that the tax advantage itself could not be regarded as a means of granting a particular advantage to the undertaking concerned by the State. ${ }^{123}$

\subsubsection{Sectoral Taxation}

Provisions in general tax legislation that apply to certain specified sectors cannot be put on a par with sectoral taxation schemes. HANCHER ET AL. give the example of special schemes for the upstream oil and gas sectors, insurance and banking sectors. ${ }^{124}$ Such arrangements may be regarded as part of the general system of taxation. I presume that 'sectoral taxation schemes' refer to special valuation systems that intend to make the administrative process of determining taxable profit more easy than under normal profit-determination rules, without leading to a substantial difference in the taxable profit actually determined.

According to WISHLADE, the Commission considers differentiated tax treatment in the banking and insurance sectors justifiable by the special nature of the activities in such sectors. Separate tax regimes for these sectors would normalise the tax treatment that would otherwise be "inappropriately disadvantaged" should the general system be applicable. ${ }^{125}$ In my opinion the use of alternative methods to determine taxable income in a more practical matter may be justifiable as long as it does not lead to a (structurally) lower tax burden than under normal profit determination rules. ${ }^{126}$ Even so, sectoral tax arrangements may contain a specific

See Commission press release IP/00/429 of 3 May 2000.

ECF joined cases C-72/91 and C-73/91 of 17 March 1993, Sloman Neptun, ECR 1993, I-887, paragraph 21.

HANCHER ET AL. (1999), section 2-032.

WISHLADE (1997), p. 17.

In principle, sector-specific profit determination is regarded specific such as in case of a tonnage tax regime for maritime shipping activities. (See paragraph II.2.3.1, infra.) In the pending case concerning a special tax regime for French headquarters and logistics centres, the Commission mentioned that an alternative method of determining income should not lead to a lower tax burden in comparison to the classical system of income determination. See OJ C 302/3 of 27 October 2001. Also see the pending Luxembourg Coordination centre regime investigation, OJ C 304/11 of 30 October 2001. 
element as a result of which certain corporations within the sector are favoured. ${ }^{127}$ An example:

The Commission opened a formal investigation into a set of Italian tax incentives that was introduced to stimulate mergers and similar restructuring activities in the banking sector. The income tax rate would be reduced with $12.4 \%$ to $12.5 \%$ for a period of five years after a merger or a similar restructuring operation, provided that proceeds would be put in a special reserve which may not distributed for a period of three years. ${ }^{128}$ Tax neutrality of the operations was guaranteed as to the disposal of certain goods and holdings. ${ }^{129}$ The Commission declared the Italian scheme incompatible with the common market. ${ }^{130}$ It however acknowledged that:

"the peculiar nature of banking could, in principle, justify the introduction of specific tax rules for the sector. However, the measures under examination do not represent an adaptation of the general system to the distinctive features of banking, but, rather, ad hoc aid having the effect of improving the competitiveness of [...] merging banks [...]. The fact that the banking sector might be in need of restructuring at a particular time is an extrinsic factor bearing no relation to the normal operation of the tax system in the banking sector [...]. For these reasons, it cannot be accepted that the measures in question are justified by the nature or general scheme of the system."131

CFI T-67/94 of 27 January 1998, Ladbroke Racing v Commission, ECR 1998, II-1, paragraphs 76-77.

There is a limit on the profit that is to be reserved. These proceeds may not exceed $1.2 \%$ of the difference between the sum of credits and debts of the post-merger bank and that of the largest pre-merger bank. The result thereof is that the tax advantage to smaller buyers would be less than the advantage to larger buyers when buying the same bank. Since the size of the business in Italy also matters, foreign banks will also be discriminated with Italian banks, according to the Commission. (I presume that only the sum of credits and debts contributable to the Italian establishment are taken into account.) The Italian Government indicated that the tax benefit has been limited to a de minimis level. However, the Commission had inconclusive evidence thereof at the time. See OJ C 44 of 10 February 2001, pages 2-5.

Also indirect taxes normally due with respect to mergers were replaced by the imposition of a fixed amount and tax neutrality was guaranteed in regard to the local taxes on the increase of the property value due at the time ownership changes.

Decision of 11 December 2001, OJ L. 184 of 13 July 2002, p. 27.

Ibid., paragraph 32. 


\subsubsection{Regional Autonomy}

Tax incentives that are exclusively available to enterprises within a certain region of a Member State are selective as such. Yet things may be different if regional fiscal autonomy plays its part. From my perception, autonomous regions may create tax measures that apply to all corporations within its jurisdiction without such measure becoming selective just for being only applicable in one region of the Member State. The Commission does not seem to rule out the concept of regional tax autonomy, although it is reticent about giving away its position on the matter. ${ }^{132}$ In regard to Basque fiscal autonomy within Spain, Advocate General SAGGIO has argued:

"The fact that the measures at issue were adopted by regional authorities with exclusive competence under national law is, as observed by the Commission, merely a matter of form, which is not sufficient to justify the preferential treatment reserved to companies which fall within the scope of the provincial laws. If this were not the case, the State could easily avoid the application, in part of its own territory, of provisions of Community law on State aid simply by making changes to the internal allocation of competence on certain matters, thus raising the general nature for that territory, of the measure in question. [...] As the Commission observed, the nature and scheme of the system, which, according to the Court, can justify treatment different from that under the legislation of general application, refer not to elements of form, such as the degree of autonomy of the regional body in question, but to the existence of a different substantive situation which justifies a deviation from the general rules. [...] The fiscal autonomy of the Basque Territories does not reflect any specificity of the territory in question - in terms of economic conditions such as level of employment, production costs, infrastructures, labour costs - which would require, indirectly, fiscal

At one time, in a negative decision concerning 7 tax incentives from the Spanish Basque Provinces and Navarre, the Commission explicitly stated that "these decisions do not call into question the tax autonomy which applies to each of the three Basque Provinces and the Comunidad Foral de Navarra, since the measures would have been regarded state aid irrespective of the type or level of the administrative body (central government, government of the autonomous community or provincial government) which had adopted them." (Press release IP/01/981 of 11 July 2001.) It did therefore not have to the address the issue of autonomy itself. The seven schemes have been discussed in paragraph II.1.5.5, supra. See also CFI joined cases T-92/00 and T-103/00 of 6 March 2002, Territorio Histórico de Álava and Others v Commission (Ramondin), not yet published, paragraph 27. In this case the Commission tried to avoid the issue of regional selectivity. Since it referred to other kinds of selectivity instead to proof the existence of state aid, the CFI could do nothing but conclude that the Commission's decision did not interfere with the territory's authority to take general tax measures within the region involved. 
treatment different from that in force in the rest of the Spanish territory." 133

From my point of view, the Advocate General is in the wrong when he considers the national tax system to be the proper benchmark to determine the presence of regional selectivity in cases like these. To my mind, the normative regime to check the element of selectivity against in case of regional fiscal autonomy would be the regional tax regime. ${ }^{134}$ Member States are free to determine the manner by which they are governed. The power of any nation to freely attribute the competence to tax to the level of government its chooses is an elementary and inherent part of the general concept and system of taxation, which is often closely related to the exercise of autonomy in regard to public expenditure. The Advocate General seems to neglect that historical and political motives may by themselves justify such regional autonomy, even in the absence of economic conditions that would require special fiscal treatment. As BACON stresses, the reason to distinct between tax incentives aimed at corporations in certain regions and local taxation is that the latter is the inherent result of placing a certain level of fiscal autonomy in the local authorities, be it on a regional level, on the level of states within a federation or on the level of the municipalities. ${ }^{135}$

Be that as it may, I do share the Advocate General's opinion that Member States could use regional fiscal autonomy as an instrument to circumvent state aid provisions. Fiscal autonomy as such is not sufficient to justify every difference in fiscal treatment. An administrative area that is established merely to make regional or local business taxation possible - without transferring any other substantial powers or duties to that region - could probably be regarded as an integral part of a scheme aiming at selective regional tax treatment. For instance, mere local variations in the collection of business taxes (such as regional rate differentiation) can be considered selective if all taxes collected are at the disposal of the national government. On the other hand, such variations may be justified if and when the region itself has certain budgetary powers. If a region can determine government expenditure in its territory, it may also be able to reduce or increase its need for tax revenue. There are some theoretical pitfalls here:

Opinion of 16 February 2000 in ECJ joined cases C-400/97-402/97, Administración General del Estado v Juntas Generales de Guipúzcoa et Diputación Foral de Guipúzcoa, ECR 2000, I-1073, paragraphs 37-38. There has not been a judgement on the merits of this case, since it was removed from the ECJ's register; the main national proceedings between the Spanish government and the Government of the Basque region of Guipúzcoa had been discontinued.

See also CFI joined cases T-92/00 and T-103/00 of 6 March 2002, Territorio Histórico de Álava and Others v Commission (Ramondín), not yet published, paragraph 64. 
Suppose a region has autonomy in matters of education, infrastructure and health care. In all other regions of a Member State these are responsibilities of the national government. National defence, maintaining a police force and social security are the sole responsibility of the national government. Under which circumstances would fiscal autonomy of the aforementioned region not lead to regional selectivity?

First, of course, the region itself should not provide specific benefits to enterprises within the framework of its general regional tax regime.

Second, the autonomous region should bear a fair share of the costs of the nation-wide responsibilities of the national government. I.e. the collective inhabitants of the autonomous region should pay an amount that is relatively equal to that of the combined nonautonomous regions (for instance, the same net amount per capita). This requires very detailed data to be made available. It is up to the autonomous region to determine how it finances its contribution within the limits of its fiscal and budgetary autonomy.

Third, the inhabitants of the non-autonomous part of the Member State should not have to contribute (directly nor indirectly) to the financing of autonomous regional expenditure as long as the average tax burden that rests on enterprises in the autonomous region does not match that of enterprises in other parts of the Member State's territory. The latter is very important: financial assistance from national resources to an autonomous region must remain possible. But when enterprises outside the autonomous region must bear costs that should normally be borne by enterprises inside that region, who now pay fewer taxes than them, then this would equal regional state aid.

This theoretical example illustrates why fiscal autonomy as such is no guarantee that regional measures taken on the basis of such autonomy fall outside the scope of the state aid prohibition. If fiscal autonomy would favour local enterprises at the cost of those enterprises that are subject to the national tax regime, then the Commission could still come to the conclusion that the autonomous fiscal system contains a selective benefit after all. Yet, we cannot rule out fiscal autonomy as a justification for regional fiscal deviations beforehand.

\subsubsection{Export Related Incentives}

Despite of the fact that export aids are among the most harmful kinds of aids in regard to supranational trade, one might wonder whether export aids are actually specific in order to be subject to the state aid regime. An aid that confers a fiscal benefit to companies that are in the export business will be available to any company from virtually any sector that chooses to engage in such business. It is not bound to any region, sector or individual company except for the fact that only - as 
a logical consequence - exporting companies are eligible. Even so, the ECJ ruled in 1969 that export aids as such fall within the scope of the state aid prohibition. ${ }^{136}$ The Commission is strictly opposed to export related aids, as the following examples will show: ${ }^{137}$

On 25 July 1973 it was determined that a French fiscal scheme implementing export aid violated the state aid prohibition. ${ }^{138}$ Upon authorisation of the French Minister of Finance, companies were allowed to deduct among other the costs of sales offices and the establishment of branches abroad and the costs of carrying out orders abroad during the first three fiscal years. The tax facility was aimed at stimulating export transactions to and the establishment of offices within the markets of other Member States.

In 1988 Greece introduced a tax system for undertakings. The percentage of tax varied progressively in accordance with the profits. However, profits corresponding to gross export earnings were excluded from the tax base. Regarding the obvious capability of affecting trade and distorting competition arising from the nature of the aid, it was considered 'incompatible with the common market' and was therefore prohibited. ${ }^{139}$

Also, in October 2000 it was determined that a Spanish fiscal scheme implementing export aid also violated the state aid prohibition. ${ }^{140}$ Under Article 34 of the Spanish corporation tax law companies were entitled to a tax credit up to $25 \%$ of among other the cost of investment in the creation of branches or permanent establishment, the acquisition of shares in foreign companies or setting up subsidiaries. These activities should be associated with the exporting of goods and services or the transaction of tourism services in Spain.

ECJ Joined cases 6/69 and 11/69 of 10 December 1969, Commission v France, ECR 1969, 523, paragraphs 18 and 20-21. In these cases the ECJ did not mention the specificity criterion as part of the article 87(1) EC definition.

Export aids are explicitly excluded from the de minimis exemption that will be addressed next in paragraph 11.3.2. 


\subsubsection{Tax Court Intervention}

In case the tax authorities are ordered to lower the tax debt of an enterprise because it falsely determined the amount of tax due, such reduction is no state aid. ${ }^{141}$ Suppose a number of enterprises would be refused certain tax facilities at first, although they were entitled to them. Should one enterprise be successful in contesting the amount of taxes levied in court any correction in tax debt resulting therefrom is not to be considered specific aid. This conclusion is not altered by the fact that competitors who did not contest their tax declaration in time will not be granted the same correction though being in a similar situation.

\subsubsection{Insolvency (2)}

General legal provisions that deal with court-supervised recovery in case of insolvency of companies may lead to a loss in tax revenue when the State gives up part of its claim like other creditors. As we have seen in paragraph 1.2.5, supra, the financial benefit of remittance of tax debt is evident. However, this kind of loss of tax revenue is not of a specific nature when the Member State would act as other (private) creditors would do; it may be the inherent result of an insolvency procedure and is not a means of granting a particular advantage to the taxpayer according to the ECJ. ${ }^{142}$ But when special insolvency provisions would allow only some large industrial companies to remain in business - knowing that their present and future tax debts will be left unpaid or by remitting their tax debts - then this will be regarded to be a specific benefit in case other companies in similar circumstances would not be granted such opportunity under normal insolvency provisions. ${ }^{143}$ A decision not to start insolvency proceedings could thus give rise to specificity.

\subsubsection{Newly Established Companies}

SCHÖN doubts whether a general tax advantage for foreign investors such as lower tax rates for newly established subsidiaries or permanent establishments could be regarded as specific if it does not target specific corporations, regions or sectors. ${ }^{144} \mathrm{It}$ probably would at first sight: once the new company is established it will be treated

ECJ 61/79 of 27 March 1980, Amministrazione delle finanze dello Stato v Denkavit Italiana, ECR 1980, p. 1205, paragraph 31 .

ECJ C-200/97 of 1 December 1998, Ecotrade v AFS, ECR 1998, I-7907 in reference to ECJ Joined Cases C72/91 and C-73/91 of 17 March 1993, Sloman Neptun Schiffarths AG v Seebetriebsrat, ECR 1993, I-887, paragraph 21. See also Commission decision C 3/2002 of 15 January 2002 concerning the opening of a formal state aid investigation in regard to Refractarios Especiales SA (OJ C 55/33 of 2 March 2002, pending). 
more favourably than its competitor who is not (and has not been) entitled to the lower tax rate..$^{145}$ But on the other hand, if a tax advantage for newcomers would be in place for a number of years, the competitor might have been entitled to the same benefit in the past. This could be the case in regard to an annual tax deduction of 5.000 Euro for a period of 4 years that is made available to any starting enterprise paying taxes on entrepreneurial income for the first time.

In my opinion an advantage like the one above cannot be qualified as state aids as long as every newly established company would be entitled to such credit. Competitors will undoubtedly be at a disadvantage once the advantage is introduced, but this is a transitional matter. From my point of view this is the inevitable result of introducing any kind of tax incentive. I therefore do not agree with the CFI that the granting of a tax base reduction to new companies as such indicates selectivity. ${ }^{146}$

\section{Compatibility with the Common Market}

\subsection{Introduction}

The principle of incompatibility as set forth in Article 87(1) EC is not absolute. General derogations to this principle are made in Articles 87(2), 87(3) and 88(2) EC. ${ }^{147}$ As is peculiar to derogations from a Treaty prohibition, they should be interpreted restrictively. The Commission must formally 'approve' of derogation in most cases, as we will see in paragraph 4 on procedure. ${ }^{148}$ Until such time, Article 87(1) EC may effectively be called a prohibition since it bans the granting of state aids that are not (yet) regarded compatible. The following paragraphs will give an overview of the derogations upon which the Commission may (or must) decide to declare a state aid compatible and their ratio.

In the six Basque cases and the Navarre case discussed in paragraph 1.5.5, the Commission argued that there was selectivity based among other on the fact that only new corporations could profit from the regime. This together with investment and job creation requirements caused selectivity in the Commission's preliminary view. In the press release reflecting the outcome of the final decision, the issue of "new corporations" was not addressed.

CFI joined cases T-92/00 and T-103/00 of 6 March 2002, Territorio Histórico de Álava and Others v Commission (Ramondin), not yet published, paragraph 49. The Commission itself did not argue that limiting an investment tax incentive to new companies led to specificity as such.

Articles 36 and 73 EC make a sector specific exception for agriculture and public transportation respectively. Article $296 \mathrm{EC}$ excludes the granting of aid to the national military defence and weapons industry from state aid supervision. These exceptions will not be further discussed. 


\subsection{Article 87(2) EC: De Jure Approval}

Article 87(2)(a) EC deems aid with a social character that is granted to individual consumers to be compatible. ${ }^{149}$ This aid is to be granted without making any restriction to the origin of the products concerned. ${ }^{150}$

The German income tax provides for limited tax allowances in regard to the costs of house building. It has been argued that such allowance may fall within the scope of the state aid definition, since it is selective by applying to a particular kind of service (i.e. to the house building sector) regardless of the fact that it is not restricted to houses build by domestic corporations. ${ }^{151}$ It is open for debate whether there would be a distortion of competition and trade within the Community (the third element of state aid), because all potential house building companies would be able to perform the subsidised activity in Germany regardless of the Member State in which they reside. ${ }^{152}$ Even if we assume this third element to be fulfilled, in regard to the social importance of stimulating the building and ownership of private houses the economic disturbance - if any - is unlikely to stand in the way of declaring a tax allowance of this kind compatible under Article 87(2)(a) EC.

Government aid in case of severe natural disasters and other exceptional occurrences can also be declared compatible, under Article 87(2)(b) EC. These exceptional occurrences do not include normal operating risks, such as price fluctuations, strikes or labour conflicts. ${ }^{153}$ It should be limited to compensation for damages that resulted from events like floods, and earthquakes in order to restore the situation $e x$ ante. ${ }^{154}$ Aid that intends to improve conditions beyond that point or aid that is

Indirect benefits - where consumers / private parties act as the primary receivers of the aid - are not excluded beforehand from the state aid prohibition, because of the possibility that enterprises may be cobenefiting from tax benefits that influence demand. See KOENIG / SANDER (2000), p. 766, and paragraph II.1.3.3, supra.

150 KOENIG and SANDER (2000, p. 765) conclude a contrario that consumer-transferred aids that discriminate between the origin of a product or service are subject to the prohibition of article 87(1) EC. SCHŌN (2000), p. 918. See also Frick (1994), p. 68 and KoschYK (1999), p. 137.

JORIS (1994), pp. 94-95. Exceptional damages from stirs and riots resulting from labour conflicts or strikes can be regarded outside the normal risk. Wars, political terrorism, large forest fires and explosions may also qualify as exceptional circumstances.

154 The French Government was allowed to grant aid under 87(2)(b) to SMEs that had to replace damaged assets and to destroy stocks as a result of the sinking of the oil tanker 'Erika', for the amount exceeding that covered by insurance. (XXX Report on Competition Policy 2000, SEC (2001) 694 final of 7 May 2001, paragraph 416). Most recently, the Commission used $87(2)(b)$ to authorise aids in the form of insurance 
granted to all enterprises within a disaster area regardless of the presence of damages to the recipient is thus not covered. ${ }^{155}$

Last but not least, there is a special provision in Article 87(2)(c) EC for aids granted to certain areas in Germany in order to compensate for the economic disadvantages caused by the former division of that Member State. It has been argued that this third exemption has no meaning anymore, but it did survive the revisions of the Treaty since the unification. The ECJ explicitly provided that this exemption only covers economic disadvantages caused by the (former) physical geographical division of Germany, not the disadvantages resulting from the political and social system previously in existence in the eastern part of Germany. ${ }^{156}$ In the view of this restriction the use of the exemption will probably be very limited.

If the Commission should determine that a fiscal aid falls within one of the three categories defined in Article 87(2) EC it must declare such aid compatible with the common market; there is no room for discretion. However, JoRIS stresses that Article $87(2)$ should be interpreted very restrictively. The Commission cannot approve of aids that are in violation of other Treaty provisions, ${ }^{157}$ as we will see in chapter III.3. The same must be held true if aid is being misused under the cloak of de jure compatibility.

\subsection{Article 87(3) EC: Discretionary Approval}

\subsubsection{Preconditions}

Unlike aids with an Article 87(2) EC objective it is up to the Commission to decide whether an aid with an Article 87(3) EC objective should be declared compatible. In doing so the Commission has a broad discretion. Several objectives have been specified in this article that may justify aid. In general, aid must have a structural effect and positive effect on the attainment of the policy objectives defined below. They must be necessary for the purpose of the objective and based on transparent regulation. Its distorting effect on intra-community competition must be kept at a minimum.

\subsubsection{Article 87(3)(a) EC}

Article 87(3)(a) EC provides an opening for approving aid to promote the economic development of areas where the standard of living is abnormally low or where there

coverage by Member States for the airline industry following the events of 11 September 2001 in New York.

See also Evans (1997), pp. 7-8.

ECJ C-156/98 of 19 September 2000, Germany v Commission, ECR 2000, I-6857, paragraphs 52-56. The economic disadvantages the ECJ refers to are "the breaking of communication links or the loss of markets as a result of the breaking off of commercial relations between the two parts of German territory."

JORIS (1994), p. 92. 
is serious underemployment. The standard for comparison is a GPD per capita (measured in purchasing power) that is below $75 \%$ of the Community average. ${ }^{158}$ On the basis of this provision, the Commission has the opportunity to approve of aids for regions in extreme difficulty, even though it is sometimes reluctant to do so in practice. The regional aid regime will be addressed more specifically in paragraph 3.3, infra.

\subsubsection{Article 87(3)(b) EC - Part I}

The execution of important projects of common European interest may be promoted by granting aids. This may among other include supra-national projects in the field of intra-community telecommunication, transportation and supply of energy. Also, the stimulation of R\&D can qualify if it would benefit the competitive position of the EC in general, for instance joined European research to create High Definition Television ('HDTV') was approved on this basis. ${ }^{159}$ It is not necessary that industries from all Member States be involved in such projects.

\subsubsection{Article 87(3)(b) EC - Part II}

Serious disturbances in the economy of a Member State may also justify the granting of aid. The whole economy or an important part thereof should be substantially affected by a downward economic trend. Indications could be mass unemployment, an increase in discharges and decline in investment. Aid with the objective recovery of the national economy in general may therefore be approved. This exemption was used among other to stabilise the economy of Greece back in 1985 that suffered from large corporate and state debts to creditors abroad and extreme pressure on the exchange rate (devaluation). ${ }^{160}$ Grants to corporations to pay off debts and to restructure were approved as well as privatisation schemes.

For the application of the state aid prohibition in most association agreements (see footnote 4, supra), there is a 4 to 5-year fiction deeming the entire territory of the country associating itself to the EC to be an 87(3)(a) region, without having to fulfil the quantitative criteria. Most (older) agreements provide a possibility for a 5-year extension depending on the economic situation. For example, such extension was granted to Poland because of its economic situation, a GPD per capita of less than $36 \%$ of the Community average (OJ L 215/38 of 9 August 2001). Similar for Bulgaria (no percentage, OJ L 144/27 of 17 June 2000), Czechia (63\%, OJ L 100/16 of 11 April 2001), Estonia (37\%, OJ L 21/11 of 23 January 2001), Latvia (27\%, OJ L. 156/31 of 13 June 2001), Romania (31\%, OJ L 230/13 of 12 September 2000), Slovakia (49\%, OJ L 217/11 of 11 August 2001) and Slovenia (71\%, 4 years, OJ L 37/9 of 7 February 2002). On the other hand, a recent proposal for an interim agreement with Croatia only provides for a one-time 4-year period (O) C 362/1 of 18 December 2001, article 35 ). 


\subsubsection{Article 87(3)(c) EC}

Aside from the extreme cases to which Article 87(3)(a) EC applies, aids to facilitate the development of certain economic areas could also be allowed under article $87(3)(\mathrm{c})$ EC. This is the most commonly used derogation for the approval of state aids. Derogation (c) aids should be part of a coherent regional policy of the granting Member State. These aids should have a positive impact on regional development and employment, and have the potential to structurally undo the regional disadvantages; this will be discussed more specifically in paragraph II.3.3. In order to determine whether a certain area is in need of support, there has to be made a comparison. ${ }^{161}$ The standard of comparison is the national average unlike the Community average mentioned in Article 87(3)(a) EC. ${ }^{162}$ Derogation (c) is extended to the so-called outermost regions as defined in article 299(2) EC. ${ }^{163}$ These regions are entitled to special treatment for their remoteness, small size, their difficult topography and climate and the economic dependence on a few products. These continuing presence of these factors restrain their economic development. ${ }^{164}$

Derogation (c) explicitly provides that the Commission may not approve aid that is affecting trading conditions to an extent contrary to the common interest of the Community. The restriction seems a bit misplaced here, since it should be applicable to any $87(3)$ derogation in order to determine the scope of the Commission's discretionary powers. ${ }^{165}$

In order to determine whether or not an aid is granted to a degree contrary to the common interest, the Commission set out certain criteria for aid measures. First, an aid measure must contribute to the development of the targeted sector in the

See the Guidelines on national regional aid, OJ C 74/6 of 10 March 1998

A maximum aid ceiling has been set for the entire Community following the Agenda 2000. On the bases of certain thresholds the Commission has to determine how the aid will be distributed between the Member States. First it has to be determined how the aid is to be distributed within the Member States. Each Member therefore needs to provide the Commission with a regional aid map, indicating which regions will be eligible for regional aid and why. The basic thresholds for eligible regions within a Member State are a GDP of $85 \%$ or less and or structural unemployment at least $15 \%$ or higher compared to the national average. Next, the relative position of the region to the Community average must be assessed. The Commission may then approve the aid map, provided that the eligibility has been determined by objective and detailed standards that give an indication of the significant disparities between the eligible and noneligible regions. In a later stadium, regional aid measures may be notified to the Commission for approval. These include the French overseas territories, the Azores, Madeira and the Canary Isles.

Outermost regions are also the ones eligible for transport aids and unlimited and non-structural reduced operating aid that intend to reduce the costs arising from the handicaps when pursuing economic activity. (See press release IP/00/845 of 26 July 2000.)

The restriction is mentioned explicitly in regard to derogations $87(\mathrm{c})$ and (d), but not in regard to (a), (b) and (e). 
interest of the Community as a whole - thus not only the Member State. Second, such aid must be necessary to initiate the development. Third, the modalities of the aid (intensity, duration, and degree of distortion of competition) must be in line with the objective pursued. ${ }^{166}$ Even though aid may be able to stimulate the achievement of certain objectives, it must still be the least distortive practical method to reach such goal. There may not be much effective and easier ways to pursue the objective, nor may the aid be disproportionate in size in comparison to the amount of aid necessary to reach the objective set. Last but not least, the cohesion principle plays its part; the lesser-developed and poorer regions should be granted a higher intensity of aid than other regions.

As the Commission indicates, regional aid can only be approved if the advantage to the development of the less-developed region weighs up to the distortions of competition. Such aid must remain neutral toward the allocation of investment and jobs between different sectors of industry; approval is unlikely if regional aid is sector specific or aimed at only certain corporations. ${ }^{167}$

\subsubsection{Article 87(3)(d) and (e) EC}

The conservation of national and European heritage and the promotion of culture are also eligible for aid (derogation (d)). ${ }^{168}$ On this basis, several tax incentives have been approved to stimulate the financing and production of national films. Last but not least, the Commission may approve of certain categories of aid that are specified by a decision of the Council by a qualified majority (derogation (e)). ${ }^{169}$ This was done in regard to aid that aimed at supporting and facilitating shipbuilding in the Community.

\subsection{Article 88(2) EC: Council Intervention}

Any Member State may apply to the Council to decide that an aid, which it is granting or will be granting, is to be considered compatible with the common market because of 'exceptional circumstances'. The Council can only act on an ad hoc basis in regard to a particular aid. Such decision can only be taken with unanimous consent and may divert from the provisions of Article 87 EC or any regulation based upon Article 89 EC. I agree with JoRIS that the Council should limit a positive decision in time and assure itself of the absolute necessity of the aid in order not to

Twelfth report on competition policy.

The level of distortion to be taken for granted will be higher for derogation (a) aids than derogation (c) aids because of the more important objective of the first.

Provided that "such aid does not affect trading conditions and competition in the Community to an extent that is contrary to the common interest". A similar clause is contained in derogation (c) as discussed in paragraph 2.3.5, supra.

The Council itself cannot approve of a specific aid in this manner. 
endanger the interests of the common market. ${ }^{170}$ However, it seems that the Council has extreme latitude in making such decision. ${ }^{171}$ Should the Commission have started an investigation procedure then it will be suspended until the Council has taken a decision. If that decision is not taken within 3 months after the date of application, it is up to the Commission to decide on the case. In practice, this exemption is rarely used outside the agricultural sector. ${ }^{172}$

\section{Special Provisions ${ }^{173}$}

\subsection{Horizontal and Sectoral Rules}

Horizontal rules set out the Commission's policy on certain state aid problems that can occur in any sector. Part of this policy is set out in guidelines. Other parts have already been codified in the form of Commission Regulations on the basis of the Council's 'Enabling Regulation'. ${ }^{174}$ The latter regulation enables the Commission to declare that certain categories of aid are deemed to be compatible with the common market and are therefore not to be notified. This may apply to several kinds of aid, such as aid in favour of small and medium-sized enterprises, research and development, environmental protection, employment and staff training. ${ }^{175}$ By nonnotification of aids that fulfil the conditions set, the Commission's workload is to be reduced so that it can aim its activities at aids that are of greater danger to the common market. There are special policy guidelines for aid regarding the rescue and restructuring of firms in difficulties and for aid in favour of for enterprises in deprived urban areas. These give guidance on compatibility of an aid, but no immediate exception of notification.

JORIS (1994), p. 496.

ECJ C-122/94 of 29 February 1996, Commission v Council, ECR 1996, 1-881.

From 1958 to 1994 there was only one successful application out of 19 that concerned non-agricultural activities. This did not concern a fiscal incentive. See JoRIS (1994), pp. 520-545.

The provisions addressed in this paragraph have frequently changed during recent years. A brief description of a selected number of so-called horizontal rules will be provided. For a general overview on all the requirements set forth in these rules, please refer to the Commission's vademecum on the rules of state aid. It can be found at its website http://europa.eu.int/comm/competition/. The text of the individual guidelines and regulations and the rules for sensitive sectors can also be found there in more detail. Information on aids to agriculture, fisheries, aquaculture and transportation can be found at the website of the competent DGs.

EC 994/98, OJ L 142 of 14 May 1998, pages 1-4.

The Commission already issued a regulation on aid to SMEs and training aid. (Nos. 70/2001 and 68/2001 of 12 January 2001, OJ L 10 of 13 January 2001.) 


\begin{abstract}
On 9 March 2000 the Commission approved an UK tax scheme concerning an R\&D Tax Credit for SMEs. The scheme is limited to fundamental research, industrial research and precompetitive development (i.e. development of prototypes that cannot be used commercially yet) as set forth in the Community framework for R\&D related state aid. ${ }^{176}$ In order to qualify for the scheme at least 25,000 GBP should be expended on staff and goods directly involved with or used in the R\&D activity. ${ }^{177}$ The tax 'credit' scheme allows for a deduction of $150 \%$ of qualifying R\&D expenditure instead of the normal $100 \%$ provided that the expenditure is not already covered by some other kind of state grant. For companies not liable to corporation tax due to lack of taxable profit, it is possible to receive a cash payment of $24 \%$ of qualifying expenditure instead of the 'credit'. ${ }^{178}$
\end{abstract}

For certain 'sensitive' sectors that had severe economic problems in the past, there are special rules that are often more restrictive than the general guidelines on state aid policy published by the Commission. Among the sensitive sectors are the coal and steel sectors, the motor vehicle sector, the shipbuilding sector and the synthetic fibres sector. ${ }^{179}$ The state aid regime does only apply to the sectors agriculture, fisheries and aquaculture as far as the Council seems fit. The normal regime applies to road transport, with the limitation that no aid may be granted whatsoever to transport equipment. Special regimes apply to other sectors of transport (air, rail and water).

The sectoral guidelines applicable to maritime transport explicitly address the issue of fiscal aid schemes and provide a basis for their approval. State aid for maritime transport has the objective to promote the competitiveness of the EC's fleets and to contribute to the development of the shipping sector and employment. It is required that fiscal alleviation schemes should either require a link with a flag of a Member State or be applicable "to the entire fleet operated by a shipowner company established within a Member State's territory liable to corporate tax, provided that it is demonstrated that the strategic and commercial management of all ships concerned is effectively carried out from within the territory" ${ }^{180}$ It must be ensured that any tax benefit will not spill over to non-shipping related commercial

The total aid may cover $100 \%$ of fundamental research, $50 \%$ of industrial research and $25 \%$ of precompetitive R\&D activities. For SMEs the two latter are increased by $10 \%$.

For exact details see decision $\mathrm{N} \mathrm{802/99}$. Also payments to a subcontractor for carrying out the R\&D activities are included for $65 \%$ when the principal retains the intellectual property rights produced. This may even be $100 \%$ if the principal and subsidiary are connected companies.

For restrictions refer to the above decision.

Upon expiration of the Treaty establishing the European Community for Coal and Steel (ECSC) on 23 July 2002, there will also be specific guidelines for the steel industry. 
activities of the company that owns the ships. The Commission has explicitly approved tonnage tax systems for the UK, Germany, the Netherlands and Spain, subject to stringent conditions in order to prevent the distortion of competition and to ensure that the tax system will lead to facilitating the development of and the employment in the shipping sector. ${ }^{181}$

\subsection{De Minimis Aids}

\subsubsection{Enabling a De Minimis Exemption}

The Commission has no discretion in determining whether an aid falls within the scope of the 87(1) EC prohibition. ${ }^{182}$ If the four elements are met, the aid is to be subjected to state aid procedure (to be addressed in paragraph II.4). However, on the basis of Article $89 \mathrm{EC}$ the Council may exempt categories of aid that fall within the scope of Article 87(1) EC from the notification procedure as it did in the Enabling Regulation. The above sequence has not been followed in regard to de minimis aid.

The Enabling Regulation in combination with the Commission regulation on de minimis aid provide that aid up to 100,000 Euro over a 3 year period is regarded not to fulfil the conditions set forth in article 87(1) EC since it supposedly lacks a certain effect on trade and competition. ${ }^{183}$ Such aid is therefore not subject to Articles 87-89 EC and needs not to be exempt from notification. This method has been used since 1992. ${ }^{184}$ It is for this reason that when the Enabling Regulation was drafted, the Commission and the Council were bound to uphold the chosen system in order not to give a signal that the chosen procedure was inconsistent with the Treaty. The de minimis exemption is not applicable when it comes to export related aids and aids

Commission decisions N 396/98, N 738/95, NN 89/97 of 12 July 2000 and N 790/99 of 2 August 2000; Commission press releases IP/00/769 of 12 July 2000 and IP/02/332 of 27 February 2002. It was brought to the attention of the Commission that certain enterprises operating tugboats were eligible for the tonnage tax regime in the Netherlands, although those tug boats also operated in the German inland waterways and ports. In the Commission's view the application of the tonnage tax on other kinds of water transport than maritime transport had however not been authorised; this fell outside the scope of the Guidelines. Therefore the Commission opened a new formal investigation that is still pending. (C 56/2001 of 11 July 2001, OJ C 298/5 of 24 October 2001.)

CFI T-67/94 of 27 January 1998, Ladbroke Racing v Commission, ECR 1998, II-1, paragraph 52; ECJ C83/98P of 16 May 2000, France $v$ Ladbroke Racing and Commission, ECR 2000, 1-3271, paragraph 25. Also refer to paragraph II.4.3.2 hereafter.

Council Regulation (EC) 994/98, OJ L 142 of 14 May 1998, pp. 1-4; Commission Regulation (EC) 69/2001 of 12 January 2001, OJ L 10 of 13 January 2001, pp. $30 \mathrm{ff}$.

OJ C 213 of 19 August 1992, page 2, as replaced by OJ C 68 of 6 March 1996, p. 9. 
that are related to the use of domestic over imported goods. ${ }^{185}$ The exemption does neither apply to the transport, agricultural and fisheries sectors since 'even small amounts of aid could fulfil the criteria of Article $87(1)$ of the Treaty in those sectors' ${ }^{186}$ Yet, it is not beyond doubt that aids in other sectors may influence competitive conditions.

Even though the Enabling Regulation intended to offer a more solid base for the de minimis regulation, it does not alter the fact that the embedding of a de minimis exemption in the present form in secondary legislation may not be in compliance with the Treaty. ${ }^{187}$ The ECJ repeatedly stressed that a negligible amount of aid cannot exclude such aid from being subject to the state aid regime. ${ }^{188}$ Even a small amount can be sufficient to influence competitive conditions and thus trade within the Community, especially when the recipient of the aid operates in a sector with strong competition. ${ }^{189}$ The definition of Article 87(1) EC contains no test whatsoever that the distortion of competition and the negative influence on intracommunity trade must be substantial. ${ }^{190} \mathrm{De}$ minimis aids can therefore not be excluded from the state aid definition in general; a Regulation cannot set aside the plain text of the EC Treaty. If in any given case the element of affecting trade and competition is fulfilled, state aid provisions do apply regardless of an aid staying below the 100,000 Euro threshold. ${ }^{191}$

I am of opinion that it is necessary to maintain a de minimis exemption in order to guarantee efficient supervision within an acceptable time limit and to reduce the administrative burden for the Commission and the governments, but I do not agree

Export related means directly linked to the quantities exported, to the establishment and operation of a distribution network or to other current expenditure linked to export activity (Article 1(b) of regulation EC/69/2001).

Regulation EC/69/2001 of 12 January 2001, OJ L10/30 of 13 January 2001, preamble, paragraph 3.

187 Contra MEDERER (1999) who considers that the new enabling regulation does create a solid legal base for the de minimis regulation, pp. 2049-2050.

ECJ C-142/87 of 21 March 1990, Belgium v Commission (Teubemeuse), ECR 1990, I-959 paragraph 43; ECJ C-278/92-280/92 of 14 September 1994, Spain v Commission, ECR 1994, 1-4103, paragraph 42; ECJ C156/98 of 19 September 2000, Germany v Commission, ECR 2000, 1-6857, paragraph 39; CFI T-67/94 of 27 January 1998, Ladbroke Racing v Commission, ECR 1998, Il-1, paragraph 59; CFI T-55/99 of 29 September 2000, Confederación Española de Transporte de Mercancias v Commission, ECR 2000, 11-3207, paragraph 92.

ECJ C-303/88 of 21 March 1991, Italy v Commission (ENI-Lanerossi), ECR 1991, 1-1433, paragraph 27; CFI T-214/95 of 30 April 1998, Vlaams Gewest v Commission, ECR 1998, II-717, paragraph 49; CFI T-195/01 and T-207/01 of 30 April 2002, Gibraltar v Commission, not yet published, paragraph 125.

190 See also CFI joined cases T-92/00 and T-103/00 of 6 March 2002, Territorio Histórico de Álava and Others v Commission (Ramondin), not yet published, paragraph 78 .

191 Of course, this will only become an issue when a competitor would object to the granting of a certain de minimis aid that affects him. See paragraph II.4.3, infra. 
with its present form. De minimis aids cannot be excluded a priori from Article $87(1)$ EC. Alternatively, it should be determined that aids up to 100,000 Euro - except for those excluded above - may be considered compatible with the Common Market on the basis of Article 87(3)(e) EC, provided that de minimis aid as such can qualify as a 'category of aid' at all. The other exemptions under 87(3) are more aimed at certain policy targets; they only exempt of aid when something is expected to happen in return. Thus it is questionable whether $87(3)(\mathrm{e})$ would provide a sufficiently solid basis for a de minimis exemption. Moreover, it would still be necessary to exclude de minimis aids from the notification obligation and the investigation procedure on the basis of Article 89 EC. To my mind, adding an explicit legal basis for a de minimis exemption to the EC Treaty is to be preferred just to be on the safe side.

We must keep in mind that the exemption applies to the total amount of aid an enterprise receives in a certain period, regardless of whether the aid is of a fiscal or non-fiscal nature. In order for the de minimis exemption to be applicable it must be guaranteed that the 100,000 Euro ceiling will not be exceeded and that there will be no overlapping with other aids. ${ }^{192}$ This makes it less likely that tax incentives are to be designed that aim at the de minimis ceiling, because other kinds of aids, for instance from local governments, could make the exemption inapplicable.

\subsubsection{The Actual Beneficiary}

Article 2 of the Enabling Regulation prescribes that the de minimis exemption is only to be granted if a beneficiary does not receive an amount of aid that exceeds a certain maximum in a given period of time. It is necessary to determine who the actual beneficiary is. The Commission argues quite rightly that

"the de minimis rule is concerned ultimately with determining who the actual aid recipient is and whether the de minimis threshold has been complied with for each recipient [...]." 193

If an aid is received by one legal entity and it is linea recta transferred to another, it will be that other entity that would be considered to be the actual beneficiary. This will be a problem in a parent-subsidiary relationship. When several subsidiaries are entitled to a fiscal aid that is authorised under the de minimis regulation, their net profit after tax will be increased. When this profit is subsequently distributed to the parent corporation, the parent will be the actual beneficiary of the aid. This would not be a problem from a de minimis point of view, as long as it would concern only one subsidiary. If either the parent itself or any of its other subsidiaries would profit from the same fiscal aid, there would be cumulation on the level of the parent. The

193 Commission decision in the Dutch Gasoline Stations case, OJ L 280/87 of 30 October 1999, paragraph 74. In the original Dutch text the Commission uses the phrase "who actually profits from the aid" instead of "who the actual recipient is". See also chapter VI.3.3. 
competing economic entity (the parent and its subsidiaries altogether) would thus benefit from an aid that exceeds the de minimis level. ${ }^{194}$ If the beneficiary issue is not faced from an economic perspective, then enterprises could split their activities over several new legal entities in order to receive de minimis aid a number of times. I.e. instead of having one company with local branch offices apply for a de minimis aid, that company turns each branch into a subsidiary (a separate legal entity) and orders each of them to apply for the aid individually. When as a result of such cumulation the actual beneficiary (the 'real recipient') receives more than 100.000 Euro this cannot be considered de minimis aid. ${ }^{195}$

We have a similar situation when a parent sells its stock in a subsidiary that received aid. The value of the stock will probably have increased as a result of the aid, unless the full benefit of the aid has already been distributed to the parent. Either way, the parent will actually benefit from the aid. If the parent sells its stock at market value then he will receive a certain cash benefit. If it is sold below market value, then a benefit may be transferred to the corporation taking over the stock in the opinion of the Commission. ${ }^{196}$

\subsection{Regional Aids}

The Commission issued Guidelines to address the issue of regional aid. ${ }^{197}$ The legal basis for such aid is split between Articles 87(3)(a) and (c) EC, ${ }^{198}$ depending on the objective and the economic situation at hand. The objective of regional aid is to develop less-developed regions by supporting sustainable investment and/or a net increase in the numbers of jobs. ${ }^{199}$

In order to ensure sustainability subsidised investment and jobs must be left intact for at least 5 years. Regional aid should stimulate "the expansion, modernization and diversify-cation of the activities of establishments located in those regions" and the settlement of new firms there. Only when such aid is ineffective by itself, it is possible to grant 'operating aid' that covers the current expenses of corporations in addition. This aid must try to alleviate certain regional handicaps and be proportional to its purpose. It may not be related to export activity and it must be limited in time and progressively reduced. ${ }^{200}$ Most fiscal state

Also see LujA (2000b) for examples.

See also ECJ C-382/99 of 13 June 2002, The Netherlands v Commission, not yet published, paragraph 37.

See the XXX Report on Competition Policy 2000, SEC (2001) 694 final of 7 May 2001, paragraph 420.

OJ C 74 of 10 March 1998, pp. 9 ff.

A general introduction to these Articles has already been provided in paragraphs 2.3.2 and 2.3.5, supra.

In the Agenda 2000 proceedings a ceiling on national regional aid has been determined per Member State by setting the percentage of the population that may be covered by such aid. The Commission will in principle not approve regional aid under either Article 87(3)(a) or (c) if that ceiling has been reached.

For the Community's outermost regions more lenient conditions apply. 
aids that are not related to investments are likely to be considered operating aid, since they affect the payment of taxes that arise in the ordinary course of business.

Under strict conditions it is allowed to grant operating aid to cover the additional transport costs suffered by companies in regions with a low population density for transportation within the territory of a Member State. ${ }^{201}$ Normally, the Commission will not approve of operating aid since it merely serves to cover recurring operating expenses that every competitor would have to make to keep in business.

A Swedish regulation provided for lower social security premiums for employees in services sectors in the northern part of Sweden, which has a low population. The Swedish government claimed that the aid was justified since it intended to cover certain transport costs. The Commission considered that there was no direct relationship between the reduction in premium payable by the employer, which was related to the size of the wage bill, and the extra transport costs incurred by companies in that region. It did not approve of the aid. ${ }^{202}$

From a tax point of view, any tax incentive that intends to compensate for transport problems to outermost regions should thus have an explicit link to such costs.

Regional investment aid may not cover more than $75 \%$ of total investment, in order to ensure the viability of such investment by securing a remaining interest of the investing corporation in the success of its investment. The type of investment aimed at is the so-called initial investment, which is defined as:

\begin{abstract}
"an investment in fixed capital relating to the setting-up of a new establishment, the extension of an existing establishment, or the starting-up of an activity involving a fundamental change in the product or production process of an existing establishment (through rationalization, diversification or modernisation)" ${ }^{203}$
\end{abstract}

This explicitly excludes investment that aims at replacing existing assets as part of normal business operation. Investment may only cover intangible assets that are used exclusively within the region, which are amortizable and which are purchased from third parties at arm's length. To a limited extend, investment in patents and know-how licences may qualify if it leads to the transfer of the necessary technology. Some examples of regional tax incentives will now be provided.

OJ C 74 of 10 March 1998, pp. 9ff, annex II. A low population density means less than 12.5 inhabitants per square kilometre.

XXX report on Competition Policy 2000 - SEC (2001) 694 final of 7 May 2001, paragraph 348. Also see press release IP/00/1510 of 21 December 2000.

OJ C 74 of 10 March 1998, pp. 9ff, paragraph 4.5 . 
On 21 October 2000 the Commission opened a formal investigation procedure into the Madeira Free Trade Zone. ${ }^{204}$ It had allowed among other fiscal aid in this zone that consists of an exemption of direct taxes until 2012 for those companies established in the zone before 2001. As of 2012 there will only be a partial exemption for these companies. The aid scheme had been approved under Article 87(3)(a) EC. Such scheme should therefore be justifiable by its contribution to regional development and be in proportion to the regional handicaps that are to be compensated. The aid as such should be temporary and be gradually digressive in time. The latter two requirements do not apply when it specifically concerns the compensation for extraordinary transport costs in remote areas and in regions with a low population density. The Commission is of opinion that this scheme does not aim for such specific compensation. It should not only be temporary and digressive as of 1 January 2000, but eligibility for the scheme should also be denied for financial sectors and sectors that involve international services (especially intra-group services and coordination centres). These sectors only contribute marginally to regional development and do not suffer from regional handicaps targeted by Article 87(3)(a) EC. ${ }^{205}$

On 14 March 2000, the Commission did approve of another fiscal aid scheme for Madeira. An income tax credit is to be granted to firms in certain sectors for up to ten years with a maximum intensity of $30 \%$ of investment expenditure. The intensity depends on the location where certain investments are made and - when applicable - the numbers of jobs created. The proportionality of the aid and the contribution to regional development seem to be ensured this way and a proper time limit has been set. In order to qualify for the tax credit a firm needs to sign a government contract in order to secure that the investment and the jobs are maintained during the period the exemptions are granted, with a 5-year minimum. ${ }^{206}$

On 28 June 2000 the Commission approved a Madeirese scheme that provides for a tax-free allowance. The amount of corporation tax relief from which all corporations with their registered office, centre of management or stable (permanent) establishment may benefit, is fixed

Also it might be considered that excluding those sectors could reduce loss in tax revenue for the Madeira region, according to the Commission. This restriction on intra-group services and coordination centres follows from the conditions set forth in the general framework on regional aid (like the requirement of actual and substantial regional investment) and cannot be interpreted as a specific influence of the code of conduct. See chapter III.1.1. Note that Madeira enjoys a special status on the basis of Article 299 EC. 
at $15 \%$ of the profits reinvested during the application of the tax scheme. The investments are to be maintained for at least 5 years. ${ }^{207}$

A tax regime provided for a special economic area (' $\mathrm{ZEC}$ ') on the Canary Islands may serve as an example of a regional aid that really intends to stimulate local economic activities. Its final approval took several years during which several alterations were made in the proposed regime. The benefit from the regime exists of among other a special corporate tax rate from 1 percent up to 5 percent. It is granted to firms in certain sectors scarcely present on the Canary Islands that make actual business investments of at least 100,000 Euro and creating at least 5 new jobs. In order to prevent companies from coming in to the area that only make a marginal contribution to regional development compared to the aid received, financial (intra-group) services and coordination centres cannot qualify for the aid. The amount of aid (the total net tax benefit) is limited in a way that the larger the firm's activities have a positive impact on regional development, the higher the aid ceiling will be. The domicile and place of effective management of the benefiting entity must be located on the Canary Islands, as well as must one of its directors. ${ }^{208}$

The Commission has considered that a temporary reduction in the tax base for new companies that meet minimum investment and job creation criteria is not as such to be considered regional investment aid (nor employment aid). The amount of benefit would eventually be related to the tax base instead of being limited to a percentage of the amount invested, the number of jobs created or the corresponding wage costs. ${ }^{209}$

\subsection{Aid to Small and Medium Sized Enterprises/Training Aid}

Aid to small and medium sized enterprises (SMEs) may be granted for investments in (in)tangible assets such as buildings, machinery and the transfer of technology, and in soft aid (i.e. the services of consultants and other knowledge sources). ${ }^{210} \mathrm{~A}$

See press release IP/00/670 of 28 June 2000; Sector-specific state aid provisions and provisions on the cumulating of aid will also be complied with on a case-by-case basis.

It is striking that the Commission considered the degree of ring fencing involved when making a decision on the compatibility of the aid. See IP/00/40 of 18 January 2000. Notice that the Canary Islands qualify as an 87(3)(a) region. For more information on the ZEC regime see PALAO (2001). Note that the Canary Islands enjoy a special status based upon article $299 \mathrm{EC}$.

Commission decision of 11 July 2001, Of L 174 of 4 July 2002, pp. 31-45, paragraph 81, in reference to the guidelines on regional aid (OJ C 74 of 10 March 1998, pp. 9ff). This decision covered the Guipuzcoa tax facility discussed in paragraph II.1.5.5 supra. 
firm is considered small when it has fewer than 50 employees and either an annual turnover not exceeding 7 million Euro or a balance sheet total not exceeding 5 million Euro. ${ }^{211}$ For a medium-sized firm these figures are 250 employees and 40 and 27 million Euro respectively. Both small and medium-sized firms should be independent, i.e. they should not be for $25 \%$ or more in the hands of one corporation or a group of corporations that does not fit the applicable definition of small or medium-sized company itself. ${ }^{212}$

Investment aid may amount to $15 \%$ of the cost for small enterprises $(7.5 \%$ for medium-sized enterprises). ${ }^{213}$ Both kinds of enterprises are allowed (soft) aid up to $50 \%$ to cover the costs of outside consultants, provided that the services rendered are not of a permanent or periodical nature or part of routine expenditures (such as regular legal or tax advice or advertising). ${ }^{214}$ Aid is also allowed if an SME participates in a specialised fair or exhibition for the first time for up to $50 \%$ of the costs of setting up and operating a stand there. There is a limitation on aid to SMEs on an individual basis in order to prevent excessive aids in case of large projects. ${ }^{215}$

Training aid may cover the personnel costs and travel expenses of trainers, travel expenses of trainees, the cost of supplies and materials needed for the training and counselling services regarding the training itself. ${ }^{216} 25 \%$ of these costs

211 A definition of 'balance sheet total' is provided in Council Directive 78/660/EEC of 25 July 1978 on the annual accounts of certain types of companies, article 12(3) in reference to articles 9 and 10 (OJ L 222/11 of 14 August 1978). In brief this total consists of: subscribed capital unpaid and formation expenses (both in so far as national law permits these to be considered an asset), fixed assets, current assets, prepayments and accrued income. Whether this definition is to be used in regard to SMEs is yet unclear, since limited national variations in determining balance sheet totals may occur. There is no direct reference to this definition for state aid purposes, although an implicit link is established by Commission Recommendation 96/280/EC of 3 April 1996 concerning the definition of SMEs (OJ L 107/4 of 30 April 1996).

The $25 \%$ threshold may be exceeded if "the enterprise is held by public investment corporations, venture capital companies or institutional investors, provided no control is exercised either individually or jointly", or "if the capital is spread in such a way that it is not possible to determine by whom it is held and if the enterprise declares that it can legitimately presume that it is not owned as to $25 \%$ or more by one enterprise, or jointly by several enterprises, falling outside the definitions of an SME or a small enterprise, whichever may apply." (Regulation EC/70/2001 of 12 January 2001, OJ L 10/33 of 13 January 2001, Annex I.)

213 Limitations apply in case regional aid is available simultaneously. (Regulation EC/70/2001 of 12 January 2001, OJ L 10/33 of 13 January 2001, Article 4(3).)

L.e. individual aids of at least 50 million Euro have to be notified as well as aids to projects with a cost price of at least 50 million Euro, that amounts to $50 \%$ of the regional aid ceiling or more or to over 40.000 Euro per job created. 
are eligible for aid. When the training aims at learning skills or getting qualifications that are transferable to other fields of work or other employers, such general training may be eligible up to $50 \% .{ }^{217}$ The training aid regulation explicitly stresses that general fiscal measures that allow an automatic tax credits for all enterprises that invest in the training of their staff are outside the scope of the aid definition. ${ }^{218}$

\subsection{Environmental Aid}

Aid may be a means to promote environmental protection in all sectors of economy. The Guidelines on state aid for environmental protection cover this kind of aid except for the agricultural sector. It is important to notice that tax exemption as a means of environmental aid will only be authorised for a ten years period subject to renewal. ${ }^{219}$

Certain limits have been set for environmental aid. Aid that covers investments in order to adapt to new compulsory standards may cover $15 \%$ of the investment for SMEs, but nil for large firms. When a firm invests in measures that exceed the most stringent Community and national standards (or when such standards are absent), any aid may cover $30 \%$ of the extra investment costs. ${ }^{220}$ Relocation costs of firms for environmental purposes may be covered up to $30 \%$ ( $40 \%$ for SMEs). For the cleaning of polluted sites, aid may cover $100 \%$ of the costs less any increase in the value of the land, plus another $15 \%$ of the costs. Such aid may only be provided when the polluter is unknown. For assisted regions, firms get a bonus of $10 \%$ or $5 \%$ for article $87(3)(a)$ and (c) regions respectively. ${ }^{221}$

Apart from covering the investment costs, aid may also target operating costs, such as waste management and energy saving. Such aid may be granted for 5 years. It may either cover $50 \%$ of eligible costs during those 5 years, or it may cover $100 \%$ in year 1 down to $0 \%$ at the end of year 5 at a progressive reduction rate. ${ }^{222}$

These ceilings may be increased for SMEs, firms in certain poorer regions and for certain categories of disadvantaged workers.

Regulation EC/68/2001, preamble, paragraph 6.

219 See MEMO/00/125 of 21 December 2000.

220 It may even cover $40 \%$ in case of energy saving investments and investments in the combined production of electric power and heat. Investments in renewable energy may also be covered for $40 \%$ and even up to $50 \%$ when it enables the supply of such energy to an entire community. For SMEs these percentages (including the $30 \%$ mentioned above) are raised with $10 \%$. (Community guideline on State aid for environmental purposes, OJ C $37 / 3$ of 3 February 2001, part E.)

The above provides only a very rough description of the very detailed Community guidelines on State aid for environmental protection (OJ C $37 / 3$ of 3 February 2001, paragraph 51). As for taxes, these guidelines give special attention to separate environmental taxes that are not embedded in direct taxes like the income tax or corporate tax. If the aid is granted in the form of a tax reduction, it may even be granted for a period 


\subsection{Rescuing and Restructuring Aid}

The Commission provided special guidelines of aid to firms in difficulty to rescue them from bankruptcy and to facilitate restructuring operations. ${ }^{223}$ This kind of aid must be justifiable, for instance by considering regional or social consequences, the need to take account of the beneficial economic role SMEs play or to secure a competitive market structure. ${ }^{224} \mathrm{~A}$ firm in difficulty is defined as a company whose capital disappeared for more than half; more than a quarter of the capital should have been lost within the last 12 months. Firms subject to standard national insolvency proceedings are also included; newly established firms do not qualify in principle. 225

Rescue aid has a temporary character and it should be granted restrictively. It attempts to keep a firm viable until a restructuring or liquidation plan has been established. Rescue aid must have the character of loan guarantees or loans to cover payments due within a year after disbursement of the last instalment of the loan to the company. Interest must be collected. If no plan is set within half a year (extendable) after authorisation of the aid by the Commission, then the loan must be reimbursed and any guarantee terminated. Fiscal aids will not qualify as rescue aids, except for the fact that postponement of payment of taxes due could be considered a loan provided that a proper interest charge is due. Rescue aid will only be approved if there is a social justification for it such as the saving of jobs, provided that it causes no undue distortion to Community competition.

Restructuring aid is granted on a long-term basis in order to restore the viability of a firm within a reasonable time limit by means of a reorganisation, rationalisation or alike. The company itself will have to make a sufficient contribution to the restructuring operation itself, by using the financial means available to it. ${ }^{226}$ As compensation for the restructuring aid, a company should limit or reduce its presence on the market (except for SMEs) unless this would lead to the creation of a monopoly or tight oligopoly. In principle, overcapacity should be reduced. There should be a coherent and realistic restructuring plan, containing among other information on restoration of long-term viability, the timeframe, the commitments and contributions by the company and third parties and the amount

of 10 years provided that the firm pays a significant proportion of the tax or that it signs an agreement to retain the investment during that period.

Guidelines of 8 July 1999, OJ C288 of 9 October 1999.

Ibid., paragraph 3.

225 The Commission explicitly states that a company that is part of a larger business group must prove that its "difficulties are its own and are not the result of an arbitrary allocation of costs within the group, and that the difficulties are too serious to be dealt with by the group itself." (Ibid., paragraph 8.)

For instance, the Commission considers the use of surplus cash available (taking postponement or reduction of debts as a result from insolvency proceedings into account), attracting loans on the market, and selling non-essential assets. (Ibid., paragraph 40.) 
and intensity of any necessary aid. The Commission will monitor the execution of this plan; not living up to this plan could lead to the retraction of approval of the restructuring aid.

Restructuring aid should be granted to a company only once. ${ }^{227}$ It may be of a fiscal nature, since there is no obligation to grant this aid in the shape of a loan or loan guarantee. Similar to rescue aid, restructuring aid must be limited to the absolute minimum necessary to facilitate restructuring; prior authorisation by the Commission is required.

\subsection{Risk Capital}

The Community encourages the use of risk capital for funding of among other business start-ups, high-tech firms and small enterprises. According to an action plan, fiscal constraints on equity should be eased in order to promote the use of risk capital. 228

Aid to promote risk capital can be conferred directly to the investors, to the companies invested in or to any fund through which the measures operates. ${ }^{229}$ Investors may be offered more favourable terms to invest as a compensation for the risk they take compared to the situation where an aid would be absent. One could think of a tax exemption or tax reduction for dividends out of risk capital. Aid to the companies in need of risk capital may lead to a reduction of the financial risk involved or a potential increase in the expected return on risk capital. Aid to intermediary funds could also contain a benefit. For instance, allowing a tax reduction on the dividends or interests received from risk capital funds that invest in certain types of businesses may stimulate participation of individuals in such funds. The after-tax-return of a risk capital fund may be brought into line with that of other funds, making investments in these funds more attractive.

The Commission requires evidence of market failure before it will authorise aid to encourage risk capital. It especially considers the disincentive from the relatively high transaction costs for small investments and the lack of reliable

It should at least not be granted within 10 years after the last restructuring period ended, unless there are exceptional and unforeseeable circumstances beyond the beneficiary's control during that period (Guidelines, paragraph 48).

See Commission communication on State aid and Risk capital of 23 May 2001 (OJ C 235/3 of 21 August 2001). The Commission addressed the issue of risk capital and state aid in detail in this communication even though it may also be covered by any of the regulations mentioned previously. In regard to risk capital - as well as to the other kinds of aid mentioned above - the Commission requires that the cumulation of aid measures to one and the same enterprises is avoided. The Member State should at least consider other kinds of state aid granted in determining the different ceilings applicable to the different aid regimes. 
information available to potential investors in new companies or SMEs, especially in regard to risky and innovative projects. ${ }^{230}$ Market failure will be deemed to exist in regard to small transactions concerning risk capital of half a million Euro or less; ${ }^{231}$ focussing aid to these small transactions will favour authorisation. The aid should cause as less distortion as possible and be proportionate to the cost disadvantage that arises from the market failure. The Commission considers that there must be an incentive; the risk capital must be made available as a result of the aid. When it is also available without such aid, the latter would not be necessary of course.

If risk capital is made available in the form of equity, then this will be in favour of a potential authorisation of the aid. A link between investment performance and the dividends or interest received will also be regarded positively, since it indicates that investments are profit-driven in a market economy. ${ }^{232}$ Part of the risk must be born by the investors themselves; they must not be fully compensated. A limitation on the investors eligible for the aid will have a negative effect on the authorisation decision. ${ }^{233} \mathrm{~A}$ sectoral focus of the aid will not be regarded negative as such, because there may be policy arguments to stimulate certain sectors such as information technology and health care. ${ }^{234}$ Another factor that may favour approval is the existence of a business plan for investments out of risk capital. Lack of an opt-out for the State's involvement in the company that received the risk capital will have a negative impact on the authorisation decision in the view of the Commission. ${ }^{235}$

\section{State Aid Procedure}

\subsection{Ex ante Supervision: Article 88(3) EC}

Article 88(3) EC provides one of the core provisions of the state aid regime:

230 Commission communication on State aid and Risk capital of 23 May 2001, paragraph VI.3.

231 Ibid., paragraph VI.5. For Article 87(3)(a) and (c) EC regions the amount is increased to 1 million Euro and 750.000 Euro respectively.

232 In regard to investment funds, the Commission proposes a link between the salary of the fund's manager and investment performance, as well as a representation of market investors in decision-making and regulatory supervision in order to ensure a commercial drive for the investments made.

233 Except when eligibility is determined by the moment of making risk capital available, for instance prior to or within a certain period after the investment itself.

234 The Commission explicitly opposes to aid focussed on the more sensitive sectors suffering from overcapacity, like shipbuilding and the coal and steal sectors.

235 The above is set forth in the Commission communication on State aid and Risk capital of 23 May 2001, part VIII. 
"The Commission shall be informed, in sufficient time to enable it to submit its comments, of any plans to grant or alter aid. If it considers that any such plan is not compatible with the common market having regard to Article 87, it shall without delay initiate the [formal investigation procedure]. The Member State concerned shall not put its proposed measures into effect until this procedure has resulted in a final decision."

This provision contains the duty to notify new and altered aid schemes to enable the Commission to determine whether such aid scheme is compatible with the common market. Until the Commission comes to its decision, a stand-still is in effect that should prevent the introduction of the proposed aid scheme or its alteration for the duration of such investigation. We will now look into the procedure set forth above in detail. The entire state aid investigation and review procedure has been formalised in a regulation on the basis of Article $89 \mathrm{EC}$. No action from the Commission is required to trigger the application of Article 88(3) EC; it only depends on whether the state aid definition is met by the financial measure that is going to be introduced or altered. ${ }^{236}$

\subsection{The Procedural Regulation}

\subsubsection{Introduction}

On 22 March 1999 the Council finally laid down a set of procedural rules for the application of article $88 \mathrm{EC}$ in a regulation. ${ }^{237}$ Until that date, the procedure merely depended on standing practice of the Commission set forth in several notices and on judgements of the Court of Justice on the procedural aspects of state aid control. The so-called 'Procedural Regulation' will be discussed below. ${ }^{238}$ Whenever the

Also see the Opinion of A-G Stix-Hackl of 29 March 2001 in regard to C-400/99, Italy v Commission (Tirrenia), ECR 2001, 1-7303, paragraphs 37-38.

Council Regulation EC 659/1999, OJ L 83 of 27 March 1999, pp. 1-9.

As addressed in footnote 4, supra, most if not all association agreements provide a provision similar to the 87(1) EC state aid prohibition. Countries that associate themselves with the EC are obliged to bring aid schemes that are already in place in line with material state aid provisions within a certain period of time from the entry into force of the agreement. The association agreements do not provide a procedural framework themselves, but there are implementing rules for some of them in regard to the monitoring of state aids. (See Bulgaria, OJ L 216/20 of 10 August 2001; Czechia, OJ L 195/21 of 11 July 1998; Latvia, OJ L 163/16 of 20 June 2001; Lithuania, OJ L 98/19 of 7 April 2001; Poland; OJ L 215/38 of 9 August 2001; Romania, OJ L 138/16 of 22 May 2001; Slovakia, OJ L 217/11 of 11 August 2001; Slovenia, OJ L 163/20 of 20 June 2001.) In the recent proposal concerning an association agreement with Croatia it is provided that 'Croatia shall establish an operationally independent authority which is entrusted with the powers necessary for the full application of [the state aid prohibition] within one year from the date of entry into 
term 'aid' is used hereafter, it will refer to aid that falls within the definition of Article 87(1) EC unless otherwise indicated.

\subsubsection{Three Kinds of Aid}

The Procedural Regulation distinct three kinds of aid: unlawful aid, new aid and existing aid. Unlawful aid means aid that is put into effect in contravention of article $88(3)$ EC. ${ }^{239}$ New aid refers to those aids that are not existing aid. ${ }^{240}$ When an existing aid is substantially modified, for instance by extending an aid scheme to a new category of undertakings increasing the number of potential beneficiaries or by increasing the amount of the advantage, it will also be treated as new aid. ${ }^{241}$

Aid that has been authorised by the Commission or the Council is referred to as existing aid. This also includes aid that is deemed to be authorised due to the fact that the Commission made no timely decision on the compatibility of aid once a procedure has started. This will be explained later on as part of the preliminary procedure. ${ }^{242}$ Also, a measure is deemed to be existing aid if it did not constitute aid in the meaning of Article 87(1) EC at the time it was put into effect "and subsequently became an aid due to the evolution of the common market and without having been altered by the Member State" ${ }^{243}$ It is hard to determine at which moment in time this measure actually became aid in the meaning of Article 87(1) EC; therefore it is also unclear when notification would have become necessary. ${ }^{244}$ SINNAEVE and SLOT argue that the reason to qualify these aid as existing aid seems to be that the Commission preferred to be able to limit such aids

force of this Agreement. This authority shall have, inter alia, the powers to authorise State aid schemes and individual aid grants in conformity with [Article $87 \mathrm{EC}$ ], as well as the powers to order the recovery of State aid that has been unlawfully granted.' The period in which all Croatian aid measures have to be checked against material provisions by that authority is limited to four years from the entry into force of the Agreement. (OJ C 362/1 of 18 December 2001, article 35.) Unlike the aforementioned implementing rules, the Croatian proposal provides for the establishment of an 'independent authority' instead of a government institution like a ministry to monitor state aids. Ibid., Article 1(c).

241 Ibid. The Commission indicates so in CFI Joined Cases T-195/01 R and T-207/01 R of 19 December 2001, Gibraltar v Commission, not yet published, paragraph 26.

See paragraph 4.2.4, infra. If the Commission fails to order the recovery of unlawful aids within the time limit set to do so (10 years), such aid are deemed to be existing aid. The recovery issue will be addressed in depth in chapter VI.

Measures that become aid "due to liberalisation of an activity by Community law" are not considered existing aid after the date fixed for their liberalisation. See Council Regulation EC 659/1999, OJ L 83/1 of 27 March 1999, article 1(b)(v). 
for the future without being forced to recover in case of a negative decision, which would have been necessary if this measures had qualified as new aid.245 To my mind this 'evolution-clause' is to be applied very restrictively in order not to undermine compliance with normal procedure. ${ }^{246}$

The term 'existing aid' includes all aid schemes and individual aid that were put into effect prior to the entry into force of the Treaty in the Member States and are still applicable thereafter. ${ }^{247}$

The definition of new aid poses a specific problem related to the functioning of the fiscal system. In case a cash subsidy is increased (in nominal amount or in percentage), such aid must in most cases be notified for renewal of approval. Now suppose we have a fiscal subsidy that reduces the tax base (thus not a tax credit), then an increase in tax rate would also lead to an increase in the total amount of benefit. ${ }^{248}$ An example:

\begin{abstract}
Companies in a certain underdeveloped region may form a fiscal reserve and attribute a maximum of 10.000 Euro each year to such reserve. The corporation tax rate is $30 \%$, so the reserve will lead to a (temporary) reduction in tax payment of 3.000 Euro. An increase of the tax rate with $1 \%$ would already lead to a reduction of 3.100 Euro. This is only a marginal example, but it could also play in regard to unlimited dotations to fiscal reserves that may run up to even millions of Euros each year.
\end{abstract}

So by changing the benchmark - the normative tax system - the amount of fiscal aid may increase without any alteration of the aid scheme itself. ${ }^{249}$ Is this then still existing aid? To my mind, the answer of this question depends on the kind of change in the tax system. In our example, renotification after every 'marginal' change in tax rates would lead to an enormous, annual workload for the governments and the Commission if the answer would be negative. This workload must be set of against a good chance of renewal of approval. For this reason, I argue that marginal changes in the benchmark do not affect the status of an existing fiscal aid scheme notwithstanding that such marginal changes may bring the Commission to reconsider its approval in the process of periodical review. However, a

SINNAEVE / SLoT (1999), p. 1159; see also paragraph 4.2.7, infra.

See in particular chapter III.1.3.1.

Council Regulation EC 659/1999, OJ L 83/1 of 27 March 1999, article 1(b). However, the Act providing the conditions for the accession of Austria, Finland and Sweden to the EC provides that only those aids communicated to the Commission by 30 April 1995 will be deemed to be existing aids. (OJ C241 of 29 August 1994, Article 144.)

Of course, an increase in tax rate is not very likely in the present competitive climate.

As for nominal tax credits, their amount will not be directly affected by an increase in the applicable tax rate. 
substantial change, such as considerable increase in statutory tax rates, should give rise to renotification if the nominal amount of tax benefit would increase. Even though renewal of approval may seem a mere formality in most of these cases it is still a necessity. ${ }^{250}$

Another example could be a fundamental change in the tax system, such as the introduction of a new or fully revised tax system. In such cases 'new' aid may actually be at stake, even though certain facilities of the old system may be introduced without hardly any alteration in the new system. A full re-evaluation of aid schemes could be appropriate, depending on the kind of change in the normative tax system. Moreover, if due to the change in the benchmark the nominal amount of benefit supersedes the de minimis borderline of 100.000 Euro then the (unaltered) tax incentive may become notifiable, new aid. In such case, normal procedure must be followed since such aid scheme was no 'state aid' prior to the change of the benchmark. ${ }^{251}$

In case a special tax scheme has been declared compatible by the Commission, it is no longer necessary to notify the individual granting of such tax incentive to taxpayers, unless the Commission has made reservations in that respect. The actual granting of an incentive that constitutes the "strict and foreseeable application of the conditions laid down in the decision approving the general aid scheme" is to be considered existing aid. ${ }^{252}$ However, the Commission may examine an individual incentive in order to determine whether it is covered by its decision to declare the scheme compatible and whether it meets any specific conditions laid down in that decision. Once it finds that it is not, the Commission may regard that individual aid as new aid and act accordingly. It may order the Member State concerned to supply all information necessary in order to make such determination; if that Member State fails to do so the Commission may treat the individual aid as if it was new aid. ${ }^{253}$

In theory it will not be necessary to renotify the entire incentive, just the increase in the tax benefit. (See Council Regulation EC 659/1999, OJ L 83/1 of 27 March 1999, Article 1(c).) However, in regard to changes in tax rate this will become rather problematic to await the outcome of a state aid procedure now that the practical consequence would be that we would only be able to apply the old tax rate to the tax base reduction in the meantime. I do not consider an increase of the tax rate to affect the actual substance of the original scheme to the exent that it is transformed into an entirely new aid regime that has to be notified. (On this issue see CFI T-195/01 and T-207/01 of 30 April 2002, Gibraltar v Commission, not yet published, paragraphs 109 and 111.)

This aid scheme did not become state aid due to the development of the common market; it is merely the consequence of a change in the national tax system of a Member State. Therefore, the former de minimis aid did not become existing aid. 


\subsubsection{The Duty to Notify}

Articles 2 and 3 of the procedural regulation restate Article 88(3) EC. Any plan to grant new aid is to be notified to the Commission in time. ${ }^{254}$ The duty to notify new or altered aids is not limited to those introduced by means of laws or regulations. It also applies to aids that arise from administrative practice. ${ }^{255}$ The notification should include all information necessary for the Commission to take a decision. ${ }^{256}$ Such aid may not be put into effect until the Commission's investigation has come to an end. ${ }^{257}$ It is not necessary to provide that certain tax laws or changes therein will only be effective after the Commission ends its investigation into notified parts of such laws that potentially contain aid. Even if it is provided in the notified tax law that it will be effective as from a certain date, this cannot alter the fact that the standstill provision takes precedence over such provision. ${ }^{258}$

The Council has enabled the Commission to exclude certain kinds of aid from the obligation of prior notification in the so-called "Enabling Regulation". ${ }^{259}$ These include aids to small and medium sized enterprises, research and development, environmental protection, employment and staff training. Stringent conditions have been set for such aids in order to be exempt of the notification procedure. The Commission is trying to improve transparency of state aid supervision by opening a public register on state aid cases and by issuing more and more Guidelines and Regulations as previously set forth in paragraph 3. Doing so contributes to the risk of non-notification, because governments will tend to check the compliance of aids with the criteria for non-notification themselves. Even though this is the objective of the "Enabling Regulation", one should consider that the Commission may have another perspective on whether the various criteria for exemption are met when it would review such aid anyway. If so, then the aid should have been notified after all so that it would have been unlawfully granted in the meantime. Therefore, the issuing of exemption criteria - for valid reasons regarding the rapidly increasing workload of the Commission - could provide for a false sense of security.

Even aids to services of general interest that may qualify under article 86(2) EC must be notified first and must be suspended during the investigation in the absence of direct effect. (Most recently EC] C-332/98 of 22 June 2000, France v Commission (CELF), ECR 2000, 1-4833, paragraphs 29-33.

For instance, see paragraph II.1.1.4., supra.

Approximately one out of five of the cases investigated was not notified, thus the State Aid Scoreboard of 18 July 2001, COM 2001(412) final, p. 17.

Either in fact, or on the basis of legal assumptions in regard to time limits. See paragraph II.4.2.4, infra. ECJ 6/64 of 15 July 1964, Costa v E.N.E.L., ECR 1964, p. 1141. Also GOTz (2000), p. 584.

EC 994/98, OJ L 142 of 14 May 1998, pp. 1-4. 


\subsubsection{The Preliminary Investigation ${ }^{260}$}

Within two months after the initial notification the Commission must take a decision on the status of the aid. It can decide that the notified aid does not constitute aid within the meaning of Article 87(1) EC. Should an aid fall within the scope of that article, then the Commission may decide not to raise objections to an aid when there is no doubt that the aid is to be regarded as compatible on the grounds set forth in the Treaty as mentioned before. The Commission's power to declare aid compatible after only a preliminary investigation is thus restricted to aids that raise no serious difficulties. ${ }^{261}$ When there is still doubt after a preliminary investigation in regard to whether there is aid or whether any aid found is compatible, the Commission must decide to initiate a formal investigation procedure. ${ }^{262}$

The aforementioned period of two months will not start until a notification is complete. The time limit can be extended with the consent of the Member State and the Commission. Should the Commission not decide within two months after notification, a Member State may implement the notified aid after giving prior notice to the Commission unless a decision is taken as yet within 15 working days after the receipt of the notice. Such aid will then be deemed to be existing aid. ${ }^{263}$

A notification is considered complete when the Commission does not request any additional information within two months after receipt of the initial notification or any additional information previously requested. Whenever the Commission is of opinion that the notification is incomplete, it may request additional information to be provided within a set period. If this information is not received or incomplete, a reminder will be send. If the requested information is not received in time again, the notification is deemed to be withdrawn unless parties agree to extend the response period. However, as a new feature introduced in the procedural regulation the Member State may inform the Commission that it considers the notification to be complete. It may either argue that the requested information has already been provided or that it is not possible to make it available. In that case, the Commission must take a decision on the basis of the information available.

See Council Regulation EC 659/1999, OJ L 83/1 of 27 March 1999, Articles 4 and 5.

Most recently, CFI Joined Cases T-195/01 R and T-207/01 R of 19 December 2001, Gibraltar v Commission, not yet published, paragraph 75 .

Among other ECJ C-204/97 of 3 May 2001, Portugal v Commission, ECR 2001, I-3175, paragraph 35. The Commission will relatively easy be able to assume the existence of doubts, thus A-G Stix-Hackl. (Opinion of 29 March 2001 in regard to C-400/99, Italy v Commission (Tirrenia), ECR 2001, I-7303, paragraph 59.)

Prior to the procedural regulation, a notified aid would be regarded to be an existing aid when the twomonth period had passed without taking any decision (such as initiating a formal investigation in case of doubts) and the Member State would not agree to an extension. See ECJ 120/73 of 11 December 1973, Lorenz v Germany and Others, ECR 1973, 1471 and ECJ C-99/98 of 15 February 2001, Austria v Commission, ECR 2001, I-1101. 


\subsubsection{The Formal Investigation ${ }^{264}$}

Whenever a formal investigation procedure is initiated, the Commission shall publish its decision and invite the Member State and any other party concerned to submit its comments, normally within one month after publication. ${ }^{265}$ In that decision, the Commission will give a summary of all relevant facts, its preliminary assessment of the aid character of the notified aid, and it will list the reasons for the doubts concerning the compatibility of the aid.

Within 18 months after the initiation of the formal investigation, the Commission should adopt a decision on the compatibility of the aid. This time limit can be extended by mutual agreement between the Commission and the Member State. If the time limit has expired, the Commission is held to give its decision within two months upon request of the Member State.

The Commission may decide that - following modifications by the Member State - the notified measure does not constitute aid. It may also decide that any remaining doubts on the compatibility have been removed and that the aid is compatible with the common market, a so-called 'positive decision'. The Commission may attach conditions to such decision upon which an aid is to be regarded compatible; it may also stipulate obligations in order to enable the monitoring of the fulfilment of such conditions. This kind of decision is referred to as a 'conditional decision'. On the other hand, it may decide to take a 'negative decision' and declare the notified aid incompatible. ${ }^{266}$ The latter will among other be the case when the information provided is insufficient to decide upon the compatibility of a notified measure. This may be the case when a Member State informed the Commission that it considered the notification to be complete, thereby not providing any additional information requested by the Commission. A Member State may also withdraw its notification as long as the Commission has not taken its final decision. ${ }^{267}$

If a Member State does not comply with a conditional or negative decision, the Commission may refer the matter directly to the ECJ. If the ECJ declares that there is an infringement of Treaty provisions (i.e. living up to the decision made on the basis 1999, thus the State Aid Scoreboard of 18 July 2001, COM 2001(412) final, p. 19.

266 The percentage of negative decisions was $2 \%$ in 1997 and $9 \%$ in 1998 and 1999, according to the State Aid

Scoreboard of 18 July 2001, COM 2001(412) final, p. 21.

In 1999835 aid schemes or individual aids were notified for 'approval' to the Commission each year. On top of that the Commission started an investigation procedure without notification in 156 cases ( $\approx 16 \%$ ). The number of decisions actually taken by the Commission in 1999 is 749 , excluding decisions to initiate a formal procedure. 43 decisions were negative. See the XXIXth Report on Competition Policy 1999 - SEC (2000) 720 Final. 
of Article $88 \mathrm{EC}$ ), the State is held to take action necessary to remove the infringement set forth in the judgement. Should it not do so, the Commission may specify - after the Member State has been enabled to submit its comments - on what points the judgement of the ECJ has not been lived up to. If the Member State does not take the necessary action within a time limit set by the Commission, the latter may again refer the case to the ECJ. The Commission must specify the amount of the lump sum or penalty payment that it considers appropriate. If the ECJ finds that the Member State has not complied with its prior judgement, it may impose such lump sum or penalty payment on it. ${ }^{268}$

Whenever incorrect information was provided during either the preliminary or the formal investigation procedure, the Commission may revoke any decision that declared a notified measure either to be (conditionally) compatible or not to be aid within the meaning of Article 87(1) EC. In that case, a new decision has to be taken after going through a new formal investigation procedure. Revoking a decision is possible only if the incorrect information was a determining factor for taking such decision. A formal investigation procedure may also be initiated if the misuse of aid is suspected, which may lead to a new decision to be taken. ${ }^{269}$

Even though the fiscal system is very complex and surrounded by confidentiality, it seems that the Commission still manages to make itself familiar with the complexities of the different fiscal systems with the help of all parties concerned. The necessary information should be made available to the Commission in the course of the investigation; procedure requires that the Community officials involved treat it confidentially.

\subsubsection{Procedure regarding Unlawful Aid ${ }^{270}$}

\section{Investigation 'without delay'}

Whenever it comes to the attention of the Commission that unlawful aid is allegedly granted, it is held to examine that information 'without delay' regardless of its source. $^{271}$ It may request information from the 'accused' Member State. The Commission may even issue an information injunction whenever information is not supplied within the time limit set by the Commission or when such information is incomplete. Failure to comply with such injunction may result in the Commission taking its decision on the basis of the information available to it. ${ }^{272}$

Thus Article 228 EC. Article 23 of Regulation EC 659/1999 (loc. cit.) restates the possibility for the Commission to go to the ECJ directly as set fort in Article 88(2) EC. Ibid., Articles 10-15.

For instance, the Commission may have received a well-founded complaint from a competitor about unlawful aid.

See ECJ C-382/99 of 13 June 2002, The Netherlands v Commission, not yet published, paragraphs 49 and 76. 


\section{Suspension}

The Commission may issue a suspension injunction, requesting a Member State to suspend any unlawful aid until the Commission has taken a decision upon its compatibility. Prior to such injunction, the Member State must be allowed to submit its comments. It must be recalled that even without a suspension injunction the Member State is prohibited by Article 88(3) EC to introduce or maintain an aid before the investigation procedure comes to an end. The suspension injunction serves as a reminder for the Member State that it violates the standstill clause. It is this injunction that enables the Commission to go directly to the ECJ in case of noncompliance without having to await the outcome of the ongoing investigation procedure. ${ }^{273}$

In tax matters it will be difficult to determine the scope of the suspension. Its purpose is to stop taxpayers from gaining a financial advantage from the alleged unlawful aid for the time being. Effective suspension can only be accomplished by acting as if the suspended tax measure never gained effect. If we take a look at fiscal reserves (i.e. tax deferral), the most extreme but also the most effective approach would be to order these reserves to be included in taxable income since such reserves should have never been formed in the first place. Yet, the cancellation of existing reserves seems rather to be a matter of recovery, as we will see hereafter. ${ }^{274}$

Suspension should at least prevent that firms would still be able to profit from the tax measure for the remaining part of the formal investigation. Taxpayers should therefore be prohibited from increasing already existent reserves awaiting the outcome of the investigation procedure. Not allowing for such increase in reserves will inevitably lead to a tax burden that would be higher than when such increases would be allowed in upcoming fiscal years (for the duration of the formal investigation).

If a taxpayer would contest not being allowed to increase a reserve in a certain year (because of a suspension order), we must be very careful with adhering to national procedure. In some Member States the taxpayer could be allowed to postpone the payment of tax in regard to any contested amount while the remaining, uncontested amount of tax is due without delay. In such cases, suspension would be ineffective because the state aid would still be considered. Postponement would actually be granted on the basis of a contested right to a fiscal aid, although that aid is subject to a suspension injunction. ${ }^{275}$ If taxpayers would be

Regulation EC $659 / 1999$, loc. cit., Article 12 confirms this possibility to open an article 228 EC procedure directly. See also ECJ C-301/87 of 14 February 1990, France v Commission (Boussac), ECR 1990, 1-307, paragraph 18.

We should be careful with the timing of payments here. It would not suffice to merely include the reserves in taxable income, because of the financial benefit that accrued from postponing tax payment for a certain period of time. See chapter VI.1 for more details on compensatory interest to undo this kind of benefit. 
allowed postponement of payment of the additional taxes due resulting from suspension, there would be no suspensory effect at all. In practice, the Member State will probably grant the postponement - if requested - as long as the extent of the obligation to suspend is not clarified. This is why it is important that the Commission can go to the ECJ directly in regard to any violation of its injunction without having to await the outcome of its investigation.

\section{Preliminary Decisions}

The decision to be taken upon examination is one of those previously set out for the preliminary investigation. If necessary, it may lead to the initiation of a formal investigation procedure. The difference between the normal investigation procedure upon notification and the procedure regarding unlawful aid is that the Commission is not bound to any time limits. ${ }^{276}$ Whenever there has been an injunction for provisional recovery such limits do apply. But even without time limits, one should consider that the Commission cannot prolong its preliminary investigation indefinitely. The duration of an administrative procedure must still be 'reasonable', taking the particular circumstances and the context of each case into consideration. 277 The preliminary investigation as such is limited by its nature; if there are still considerable doubts left after some time about the presence or compatibility of an aid then the Commission should proceed with a formal investigation procedure. Although there are no official time limits in regard to opening such procedure, once the Commission determines that the situation is not more or less evident, then it should proceed with the next stage of investigation. A preliminary investigation of several months or even years would not be in proportion to the role this kind of investigation is meant to play. ${ }^{278}$

With the exception mentioned in footnote 283 , infra.

CFI T-95/96 of 15 September 1998, Gestevision Telecinco v Commission, ECR 1998, II-3407, paragraphs 74-

75. Even though this judgement merely concerned a state aid case where a competitor complained to the Commission and the latter agreed to start an investigation, it is evident that the Commission should always act within a reasonable period of time even in the absence of any time limit. Whatever is to be considered reasonable in a specific case however, is still a matter for the courts to determine. Also see SINNAEVE and SLOT (1999), p. 1176.

One obvious difference between aid that is already being unlawfully granted and aid that is to be granted, is that in the first case the actual effects of such aid could be known. This however would bring a Member State that grant unlawful aid in a favourable position compared to other States that do follow proper procedure. Therefore, the Commission does not have to proof that the aid measure actually affects trade or distorts competition. (ECJ C-301/87 of 14 February 1990, France v Commission (Boussac), ECR 1990, I-307, paragraph 33; T-214/95 of 30 April 1998, Vlaams Gewest v Commission, ECR 1998, II-717, paragraph 67.) This does not relieve the Commission from its duty to proof that trade and competition could have been expected to be affected or distorted at the time the aid should have been notified. 


\section{Recovery}

When a negative decision is taken in case of an unlawful aid, the Commission will decide that the Member State must take all measures necessary for a full recovery of the aid from the beneficiary. ${ }^{279}$ Recovery of unlawful aid is the logical consequence of its unlawfulness, according to the ECJ. ${ }^{280}$ Even though the ECJ 'merely' ruled that the Commission is allowed to require recovery, the Procedural Regulation obliges the Commission to do so. By doing so, the Council reduced the leverage of the Commission in regard to recovery. Once aid is illegally granted, it needs to be recovered, except when recovery would be "contrary to a general principle of Community law" like the protection of legitimate expectations. This issue will be addressed in chapters VI and VII.

Interest is payable over the period that the beneficiary had the aid at its disposal, thus from the date of receipt until the date of repayment. ${ }^{281}$ Recovery must be effected without delay and in accordance with the national procedures of the Member State concerned, provided that they allow for the immediate and effective recovery. Member States must use all necessary means available in their legal systems without prejudice to Community law. In 1983 the Commission already issued a general warning to potential beneficiaries of aid that they may have to refund unlawful aid. ${ }^{282}$

If there is no doubt about the aid character of a measure and there is a serious risk of substantial and irreparable damage to a competitor of the beneficiary of the unlawful aid, the Commission may even order the provisional recovery of such aid - without closing the formal investigation - if it considers such action urgent. ${ }^{283}$ Should the Member State not be willing to comply with a recovery injunction, the Commission may call directly upon the ECJ. ${ }^{284}$

The Commission is not obliged to determine the exact amount of recovery itself; it should only provide the necessary information for the Member State to

In 1998 the number of recovery decisions were 27 and in 199924 , excluding aid to agriculture and fisheries. (State Aid Scoreboard of 18 July 2001, COM 2001(412) final, p. 23.)

ECJ 142/87 of 21 March 1990, Belgium v Commission, ECR 1990 I-959 and C-305/89 of 21 March 1991, Italy v Commission, ECR 1991, 1-1603.

No interest is due when national legislation provides that no interest can accrue from any company debts from the date a company is in bankruptcy. (ECJ C-480/98 of 12 October 2000, Spain v Commission (Magefesa), ECR 2000, 1-8717, paragraph 36.

OJ C 318 of 24 November 1983.

283 This injunction can only be issued if it concerns aid implemented after 15 April 1999. If provisional recovery is ordered, the Commission must take a final decision within 18 months, as described in paragraph 4.2.5, supra. See Article 11(2) of Regulation EC 659/1999 (loc. cit.). It is permissible to pay restructuring aid upon recovery with the authorisation of the Commission.

Article 12 opens the possibility to go for an Article 228 EC judgement directly. 
determine such amount "without overmuch difficulty". 285 If a certain tax benefit is to be recovered, the Member State may correct the recoverable amount by deducting other sums to which the recipient becomes entitled in accordance with the national tax system due to recovery of the benefit. ${ }^{286}$ For instance, when certain personal allowances are limited as a percentage of the gross taxable amount an increase in that amount by retracting a tax incentive will lead to a higher deductible allowance.

Recovery of an aid is limited to 10 years from the day the aid was awarded to the beneficiary. The Commission may interrupt this limitation period by taking action related to the unlawful aid. Any action of a Member State at the request of the Commission also interrupts the period. A new 10-year period starts to run following an interruption. This period is suspended for as long as the Commission's decision is pending before the ECJ.

The Commission may take into consideration that previous aid has not been recovered when it comes to determining the compatibility of new aid. ${ }^{287}$ It may prohibit payment of aid that it regards compatible, until the enterprise has repaid unlawful aid it received previously. 288 The issue of implementing a recovery decision in national legislation in regard to the interests of the recipient of the aid will be discussed extensively in chapters VI and VII.

\subsubsection{Periodical Review ${ }^{289}$}

The Commission takes about 630 decisions on state aids each year; almost $87 \%$ of the aids is approved without objections (without opening a formal procedure). Another $6 \%$ is approved after such procedure (of which less than $1 \%$ conditionally). Negative decisions are taken in about $7 \%$ of all state aid cases. ${ }^{290}$ The $93 \%$ of the aids that do get approved are not necessarily on the safe side forever.

Existing aid schemes are subject to periodical review by the Commission. It will have to obtain the necessary information from the Member States. Part of this information will be provided in the annual reports that Member States have to

ECJ 102/87 of 13 July 1988, France v Commission, ECR 1988, 4067, paragraph 33; ECJ C-480/98 of 12 October 2000, Spain v Commission (Magafesa), ECR 2000, 1-8717, paragraph 25.

CFI T-459/93 of 8 June 1995, Siemens v Commission, ECR 1995, II-1675, paragraph 83. When it concerns recovery of taxes, the fact that a certain tax regime has to be considered on the basis of domestic legislation, the Commission is entitled merely to make a general statement on the recoverable amount, thus CFI T67/94 of 27 January 1998, Ladbroke Racing v Commission, ECR 1998, II-1, paragraph 188.

ECJ C-355/95P of 15 May 1997, Textilwerke Deggendorf v Commission, ECR 1997, 1-2549.

CFI Joined cases T-244/93 and T-486/93 of 13 September 1995, Textilwerke Deggendorf v Commission, ECR 1995, II-2265.

Council Regulation EC 659/1999, OJ L 83/1 of 27 March 1999, Articles 17-19.

1998-2000 averages. Source: State Aid Scoreboard, second edition, COM (2001), 782, final, p. 34. 
submit for monitoring. ${ }^{291}$ Whenever the Commission has serious doubts whether a decision not to raise objections or a positive or conditional decision is lived up to, it may undertake on-site monitoring visits. A Member State must allow such visits, after having been allowed to submit its comments. There will be prior written notification of such visits to a Member State. ${ }^{292}$ The officials may enter any premises and land of the undertaking concerned, they may ask for oral explanations on site and even examine and take or ask for copies of books and other business records. The Member State will provide the necessary assistance to enable the officials to carry out their visit.

Whenever it comes to the preliminary conclusion that an existing aid is no longer to be regarded as compatible, it must give the Member State the opportunity to submit its comments. It then may recommend a Member State to take appropriate measures, such as amendment of an aid scheme, the introduction of procedural requirements or even the abolition of an aid scheme. A Member State may inform the Commission that it will accept the recommendation and bind itself thereby. If it does not accept the recommendations, the Commission may initiate a formal investigation procedure and take a new decision. In such cases it often will be necessary to create some kind of transitional period for existing aid schemes as a result of the expectations raised with the beneficiary. The decision on an Italian aid scheme to corporations on Sicily is of interest here. ${ }^{293}$

On 25 March 1998 the Commission sent a fax to the Italian government by mistake stating that it did not object to the aid scheme. On 2 July 1998 there was a decision to initiate a formal investigation procedure which ended on 2 February 2000 when the Commission declare the aid to be incompatible. The Commission recognised that for aid granted between 25 March and 2 July the beneficiaries had legitimate expectations. However, since the announcement not to object turned the aid scheme into existing aid - without there being any indication for either the government or the beneficiaries that the fax was sent by mistake - the Commission cannot declare aid incompatible granted prior to publication of the new decision. The Italian government has not addressed this issue because no aid had been granted under the proposed scheme.

One of the most heard arguments not to let existing aid regimes continue is the fact that competition emerges in a sector where it was (nearly) absent before. For instance, the Netherlands received the recommendation to discontinue the exemption of fully government-owned enterprises from corporation tax in regard to

Council Regulation EC 659/1999, OJ L 83/1 of 27 March 1999, Article 21.

If a Member State has justified objects to the experts that are to join the visiting officials, the experts will be appointment in mutual agreement with the Member State and the Commission.

Decision 2000/359/EC, published in OJ L 129 of 30 May 2000, pp. $21 \mathrm{ff}$. 
Amsterdam Schiphol Airport. The Commission was of opinion that this tax break was no longer compatible with the Common Market, because of the 'increasingly liberal and competitive environment' that major airports in the Community are in. ${ }^{294}$ The Netherlands agreed to discontinue this regime as of 2002 in conformity with the Commission's request.

\subsection{Appeal to the EC Courts}

\subsubsection{Securing Procedural Rights}

Interested parties may submit their comments upon publication of a decision to open a formal investigation procedure. They may also inform the Commission of any alleged unlawful aid or misuse of aid. Should the Commission find that there are insufficient grounds for looking into a case based upon these allegations, it will inform the interested party. According to SINNAEVE and SLOT, the latter seems limited to cases where the complainant addresses authorised measures or measures that manifestly do not constitute aid. If this is not obvious, a refusal to take action may be appealable because the Commission is obliged to examine possible unlawful aid and to take one of the decisions described for preliminary investigations. ${ }^{295}$

In the Piaggio case the ECJ ruled very clearly that proper procedures should be followed. The Commission classified a new aid as existing aid even though it was not notified. It did so on reasons of practical expediency, including the fact that its own doubts on the classification of an aid scheme extended over a period of 14 years, the expectations of traders subject to the scheme, its infrequent application and the impossibility of recovery. The ECJ did not accept this position. ${ }^{296}$ In determining whether aid is new or existing it is not the Commission's subjective assessment that is decisive. If the aid is new according to objective standards (nowadays the Procedural Regulation), proper procedure should be followed.

In a notice on co-operation between national courts and the Commission in the field of state aid, the Commission expressed that when it comes to safeguarding the rights and interests of third parties national courts may be better placed to ensure that breaches of the duty to notify as set forth in Article 88(3) EC are dealt with and remedied since that article has direct effect in the legal order of Member States. In such case the national court will first have to consider whether a certain measure constitutes aid within the meaning of Article 87(1) EC. Then it will have to consider

SINNAEVE/Stor (1999), p. 1185. They also remark that it is not certain whether a complainant would be considered the addressee of a letter stating that there is no ground for review, since State Aid decisions are addressed to the Member State in general. (Ibid., pp. 1189-1190). Also see ECJ C-313/90 of 24 March 1993, CIRFS v Commission, ECR 1993, I-1125. 
whether it is new or existing aid. Third, it will have to determine whether such measure was duly notified (if and when necessary). ${ }^{297}$

The national court can be guided by prior case law of the ECJ and the CFI and decisions issued by the Commission. It may even refer questions to the ECJ or ask the Commission for assistance. Even though it is not up to the national court to decide on the compatibility of an aid, it may determine whether there is aid that should have been notified and take appropriate action. This may include ordering notification or granting interim relief to competitors, for instance by suspending an individual aid or an aid scheme. The national court may even render a judgement once an aid scheme has been brought to the attention of the Commission, for instance by ordering the provisional repayment of aid that was not notified in order to protect the interests of third parties. ${ }^{298}$ Even when the Commission already found that a certain measure is not aid, having conducted a preliminary investigation only, this would not prevent a national court from coming to an opposite conclusion based on its legal analysis of the state aid definition. ${ }^{299}$

\subsubsection{Entering Proceedings}

When the Commission decides to declare an aid compatible after only a preliminary investigation, all interested parties that were entitled to make a comment under the formal procedure (like competitors of the beneficiary that are significantly affected in their position on the common market) may go to the CFI in order to secure their procedural rights that they would have enjoyed under the formal procedure. ${ }^{300} \mathrm{~A}$ decision that a certain measure does not constitute aid can be dealt with accordingly. ${ }^{301}$ As we have seen before, the Commission may only skip the formal investigation if it has no doubt regarding the compatibility of an aid; such decision must be properly motivated. Should compatibility be established after a formal investigation procedure, parties that are directly and individually concerned may pursue annulment at the CFI.

A competitor is not by definition regarded as an interested party without having certain characteristics that distinguish him from other competitors, such as the fact that his competitive position could be seriously affected by the contested

OJ C 312 of 23 November 1995, pp. 7ff., paragraph 16.

ECJ C-39/94 of 11 July 1996, SFEI and Others v La Poste and Others, ECR 1996, I-3547.

President of the CFI, Joined Cases T-195/01 R and T-207/01 R of 19 December 2001, Gibraltar v Commission, not yet published, paragraph 99.

ECJ 169/84 of 28 June 1986, COFAZ and Others v Commission, ECR 1986, 391; ECJ C-198/91 of 19 May 1993, Cook v Commission, ECR 1993, I-2487, paragraphs 13-26; C-225/91 of 15 June 1993, Matra v Commission, ECR 1-3203, paragraphs 15-20.

ECJ C-367/95 P of 2 April 1998, Commission v Sytraval, ECR 1998, I-1710, paragraph 47; CFI T-11/95 of 15 September 1998, BP Chemicals v Commission, ECR 1998, II-3235, paragraphs 164-166. 
decision. ${ }^{302}$ Organisations that represent a certain discipline or sector of industry may qualify if they are affected in their position as negotiator for their discipline or sector. ${ }^{303}$ They may also qualify when acting as a representative of one or more of their members in accordance with its regulations, provided that those Members are directly and individually affected and did not resist to their representation. ${ }^{304}$

Any Member State can challenge a Commission decision directly at the ECJ, without having to be an 'interested party'. But unlike a Member State a region of such Member State with (autonomous) taxation powers is not entitled to the same treatment in case of annulment proceedings. We must consider that even in case of tax measures of subnational authorities, it will be the Member State that will be the addressee of any Commission decision regarding state aids. Like other interested parties the subnational authority must bring the matter before the CFI first, ${ }^{305}$ and it must be directly and individually affected by the Commission's act. ${ }^{306}$

In case the Commission declares an aid incompatible the beneficiary may start proceedings, provided that the aid was of direct and individual concern to him in particular. Yet, the mere fact that a person would be entitled to a certain fiscal aid does not entitle him to start proceedings if he does not distinguish himself from other potential beneficiaies. In regard to a special depreciation scheme for the entire German aviation sector the ECJ ruled:

"Because it prohibits the extension of tax provisions having general application, the contested decision, although addressed to a Member State, appears, vis-à-vis the potential beneficiaries of those provisions, to be a measure of general application covering situations which are determined objectively and entailing legal effects for a class of persons envisaged in a general and abstract manner. "307

In general,

"an undertaking cannot, in principle, contest a Commission decision prohibiting a sectoral aid scheme if it is concerned by that decision

ECJ 25/62 of 15 July 1963, Plaumann v Commission, ECR 1963, 95; ECJ 169/84 of 28 January 1986, Cofaz and Others v Commission, ECR 1986, 391, paragraphs 22 and 25. CFI T 447-449/93 of 6 July 1995, Aitec and Others v Commission, ECR 1995, II-1971, paragraph 60.

306 ECJ 222/83 of 11 July 1984, Municipality of Differdange and Others v Commission, ECR 1984, 2889; CFI T214/95 of 30 April 1998, Vlaams Gewest v Commission, ECR 1998, II-717, paragraphs 26-31.

CFI T-86/96 of 11 February 1999, ADL and Happag-Lloyd Fluggesellschaft v Commission, ECR 1999, II179, paragraph 45. 
solely by virtue of belonging to the sector in question and being a potential beneficiary of the scheme." 308

Therefore, a potential beneficiary cannot claim to be directly and individually affected when competing undertakings are in a similar position. ${ }^{309}$ An organisation representing such undertakings cannot claim to be individually affected when its Members are neither. However, this could be different if the organisation is a negotiation partner to the Member State representing the sector as a whole in the process of creating the fiscal scheme. ${ }^{310}$ Should recovery be at issue, then any beneficiary facing recovery - those who actually received a tax benefit while the stand-still was in effect - will evidently be directly and individually affected.

\subsubsection{Freedom of Assessment}

The Community courts cannot substitute their own assessment of an aid scheme for that of the Commission, ${ }^{311}$ especially not within the economic sphere. ${ }^{312}$ They must restrict themselves to

"checking that the rules on procedure and the statement of reasons have been complied with, that the facts are materially accurate and that there has been no manifest error of assessment or misuse of powers". 313

ECJ joined cases C-15/98 and C-105/99 of 19 October 2000, Italy and Sardegna Lines v Commission, ECR 2000, 1-8855, paragraph 33 .

L.e. an aid decision cannot be regarded to affect a person 'by virtue of its objective capacity as a potential recipient' in the absence of factors that differentiate him from all other operators. (See CFI T-9/98 of 22 November 2001, Mitteldeutsche Erdöl-Raffinerie v Commission, ECR 2001, II-3367, paragraphs 77-85.) The Commission's refusal to approve of an extension in time of a generally applicable investment scheme for one potential beneficiary in particular (because of a delay in an eligible investment beyond its control) could be such a factor (ibid.).

CFI T-86/96 of 11 February 1999, ADL and Happag-Lloyd Fluggesellschaft v Commission, ECR 1999, II179.

311 The ECJ may also review a Council decision when an article 88(2) EC derogation has been granted. See ECJ C-122/94 of 29 February 1996, Commission v Council, ECR 1996, 1-881.

ECJ C-225/91 of 15 June 1993, Matra v Commission, ECR 1993, I-3203, paragraphs 23-24.

313 CFI T-288/97 of 4 April 2001, Regione autonoma Friuli-Venezia Giulia v Commission, ECR 2001, II-1169, paragraph 74 and the ECJ cases referred to therein; ECJ C-169/95 of 14 January 1997, Spain v Commission, ECR 1997, 1-135. The Commission does not need to supply specific reasons to recover in case of unnotified aid, thus ECJ Joined Cases C-278/92, C-279/92 and C-280/92 of 14 September 1994, Spain v Commission, ECR 1994, I-4103, paragraph 78. 
Thus the Courts may only marginally review the Commission's actions when it comes to declaring an aid compatible under Article 87(2) and (3) EC. Therefore it is important for beneficiaries to submit their comments in the formal procedure so that the ECJ can take these into consideration as part of its marginal review. It must also be noticed that a Member State cannot rely on information that it did not bring to the attention of the Commission in the course of its state aid investigation at the ECJ. The legality of a state aid decision can only be review on the basis of the information the Commission had available at the time it adopted its decision. ${ }^{314}$

The Commission has almost no discretion in regard to whether the prohibition of Article 87(1) EC applies. This Article contains a legal concept that must be interpreted objectively. Therefore a full review is possible in regard to the question whether a fiscal measure is to be qualified as state aid. ${ }^{315}$ The same is true in regard to procedural issues. As we have seen in the Piaggio case, ${ }^{316}$ the qualification of aid as either 'new' or 'existing' is a legal matter subject to full review. ${ }^{317}$ The President of the CFI points out that

\begin{abstract}
"State aid is a legal concept which must be interpreted on the basis of objective factors. Accordingly, the classification of State measures by the Commission as new or existing aid must, in principle, having regard both to the specific features of the case and to the technical or complex nature of its assessments, be subject to a comprehensive review by the Community judicature $[\ldots],{ }^{\prime \prime 318}$
\end{abstract}

This provides the basis for a new kind of procedure that is not as such provided in the Procedural Regulation. If the Commission decides to start a formal investigation into an aid measure without using the procedure prescribed for existing aid, then this could be the subject of an annulment procedure if the (provisional) treatment of such aid as non-existing aid is disputed.

The ECJ ruled that a Commission decision to initiate the formal investigation into a measure it (provisionally) classifies as new aid - while the latter is disputed by the Member State - entails independent legal effects, particularly in regard to

C-278/92, C-279/92 and C-280/92 of 14 September 1994, Spain v Commission, ECR 1994, I-4103, paragraph 31; ECJ C-382/99 of 13 June 2002, The Netherlands v Commission, not yet published, paragraph 76.

CFI T-67/94 of 27 January 1998, Ladbroke Racing v Commission, ECR 1998, II-1, paragraph 52; ECJ C83/98P of 16 May 2000, France v Ladbroke Racing and Commission, ECR 2000, 1-3271, paragraph 25. 
(the possibility of) suspension of aid payments. ${ }^{319}$ It implies that the Commission does not intend to examine the aid in accordance with existing aid procedure, which would rule out the application of the standstill clause. ${ }^{320}$ This may have a severe impact on trading. Beneficiaries may be tempted not to accept new sums or to retain sums received in the prospect of potential repayment (instead of using such sums for investment or otherwise). Also, trading partners may take account of the (expected) change in the beneficiary's financial situation. ${ }^{321}$ These effects may be irreversible, so that a successful action brought against the Commission's final decision could have no effect. Therefore, a Member State can challenge the opening of a formal investigation into an aid that the Commission classified as new aid without awaiting the outcome of the procedure, if necessary. ${ }^{322}$

It is still unclear what should happen once a Commission decision is actually annulled; the Procedural Regulation does not provide an answer. Probably, the standstill clause will regain effect until a new decision is taken. Whether the clause revives from the date of the Court's judgement or whether it revives as from the date the decision was taken - which would mean that its effect was never suspended - is yet unclear. ${ }^{323}$

ECJ C-400/99 of 9 October 2001, Italy v Commission (Tirrenia), ECR 2001, 1-7303, paragraphs 60-62. The ECJ explicitly considered this decision not to be a simple preparatory step, which would prevent any action being taken immediately. See also CFI Joined Cases T-195/01 and T-207/01 of 30 April 2002, Gibraltar v Commission, not yet published, paragraphs 82-83. ECJ C-400/99 of 9 October 2001, Italy v Commission (Tirrenia), ECR 2001, 1-7303, paragraph 58. See ibid., paragraph 59.

A word of caution seems appropriate. By arguing that an aid is existing aid instead of new aid, this would mean that the Member State implicitly concurs that the scheme at issue qualifies as 'state aid' in the meaning of Article 87(1) EC. Furthermore, should the ECJ rule that there is new aid, then it seems very unlikely that the Commission will find otherwise upon closing the formal investigation. Yet, it is still up to the Commission to take a final decision regarding the compatibility and recovery of such new aid. 


\section{LIMITATIONS ON THE DESIGN OF DIRECT TAX SYSTEMS}

\section{Harmful Tax Competition}

\subsection{The Proposed Role of State Aid}

In the 1990s, a change of thoughts in the matter of fiscal state aids was brought about by the discussion on harmful tax competition. As a result of this, the Commission's perspective on the issue of fiscal aids has evolved during the last decade. A preliminary indication thereof can be found in the second survey on state aids (1990). The Commission reported that it is not only the other Member State or the competitor abroad that may suffer from fiscal incentives:

"Not only are enterprises in other Member states put at a competitive
disadvantage by [state] aid because the aided enterprises are favoured
in a way outside the normal fiscal or social security systems that
contribute to the equilibrium between Member States, but also
enterprises not receiving aid in the same Member State are
disadvantaged and pay higher taxes directly or indirectly."

The evolution was furthered in December 1997 when the EC Member States committed themselves to the abolishment of harmful tax competition by adopting a Code of Conduct for (Direct) Business Taxation. ${ }^{1}$ This Code provides for a basis upon which 'harmfulness' can be determined by a group of officials reviewing existing fiscal measures in all Member States, the so-called PRIMAROLO group. ${ }^{2}$

The Code covers tax measures (either legal provisions or administrative practices) that do or may significantly affect the location of business activity within the Community. Such measures are considered potentially harmful, if they provide for a significantly lower effective level of taxation than the level generally applicable 
in a Member State. When assessing the harmfulness of an aid, certain other factors should also be taken into account:

- whether tax advantages are only available for non-residents or in regard to transactions with non-residents;

- whether such advantages are kept from the domestic market in order not to affect the national tax base (ring-fencing);

- whether advantages are granted even in the absence of real economic activity and substantial economic presence in the Member States that grants them;

- whether transfer pricing rules divert from the international accepted (OECD) 'at arm's length' standard;

- whether tax measures are transparent.

The Member States committed themselves to eliminate harmful tax measures ("rollback") taking into account the Council's discussion in regard to the review process and to refrain from the introduction of new harmful measures ("standstill"). ${ }^{3}$ Despite of this commitment, the Code is not intended to be a legal instrument of the Community. This keeps it out of reach for the Community's Courts. It rather is a statement of mutual understanding between parties. ${ }^{4}$ Even though the Code's status is still that of a gentlemen's agreement, it is likely that States will agree on some sort of binding scheme to dissolve certain harmful tax measures in different member states as part of the so-called 'Monti-package'. The PRIMAROLO group has published a list of 66 measures with harmful elements together with 54 dissenting opinions. The ECOFIN Council that had established the PRIMAROLO group never adopted this list. Instead, the group focussed on the designing of criteria to address financing permanent establishments, holding company regimes and headquarter regimes. ${ }^{5}$

The Commission's 1998 notice on the application of state aid rules in regard to business taxation pays special attention to the influence of the Code of Conduct on the state aid regime. As Commissioner MONTI announced, ${ }^{6}$ he will look into certain business taxation measures - part of them already approved in the past - in order to determine if they contain an element of aid and, if so, whether they should be

The preamble emphasises that the Code is "a political commitment and does not affect the Member States' rights and obligations or the respective spheres and competence of the Member States and the Community resulting from the Treaty". It is the intention of the EC Council (and the Commission) to ensure that existing and future tax legislation of countries that are on the doorstep of acceding to the Communities are brought in compliance with the principles of the Code (OJ L 44 of 14 February 2002). NIJKAMP (2001).

Press release IP/00/182 of 23 February 2000. Note that Commissioner MONT is the Commissioner responsible for competition as of 1999. At the time of the 'Monti-package' he was the Commissioner responsible for taxation. 
discontinued. This will be done regardless of the outcome of the political debate concerning the Code of Conduct or any qualification of the 'harmfulness' of a certain tax measure. Even so, the Commission will take into account the effect of a fiscal aid brought to light by the code of conduct when assessing its compatibility.?

At first sight, the Code seems to have had some influence on the standards that are set for the review of (potential) regional aids. The 1998 notice stresses that the Commission must ensure that regional tax measures that are to be investigated really contribute to regional development and relate to activities having a local impact. This excludes most offshore activities since they do not sufficiently support the local economy. ${ }^{8}$ Measures should also relate to real regional handicaps. The notice stresses that
"it is open to question whether there are any real regional handicaps involved in activities for which for example transport costs are of little relevance, such as financing activities, which lend themselves to tax avoidance". 9

Yet, disapproval of proposed tax incentives for not having the economic impact pursued is a matter of general state aid policy. Such decision cannot be attributed to the Code. An example:

Until 1998, the Commission approved of several fiscal aid schemes in Ireland being an Article 87(3)(a) region. These schemes consisted of a special $10 \%$ corporate tax rate in deviation of the general Irish rate starting at $25 \%$. The schemes applied to the manufacturing sector and certain firms in the International Financial Services Centre ('IFSC') and the Shannon customs-free airport zone. The Commission remarked that the existence and importance of regional handicaps for the supported firms had not been demonstrated. ${ }^{10}$ In case handicaps are found to be non-existent, no aid can be granted to compensate alleged handicaps. The Commission has recommended that all schemes be terminated; transitional restrictions apply up to the end of 2005. ${ }^{11}$

Even though harmfulness should not play a role in the Commission's decision in my opinion, the explicit mentioning of 'tax avoidance' in the notice indicates that

OJ C 384/3 of 10 December 1998 (hereinafter: the 1998 notice), paragraph 30. 1998 notice, paragraph 33.

Ibid. regional handicap for the sectors involved. 
this concept plays at least a background role in an investigation. The Commission considers that measures are to be examined in a Community context, thus taking negative effects on other Member States into account. ${ }^{12}$ These negative effects tend to include those effect revealed by the examination in the scope of the Code. ${ }^{13}$

\subsection{Crossing the Outer Limits of State Aid Control}

The influence of the Code of Conduct puts forward a fundamental question. May the Commission exert its discretion in regard to Article 87(3) EC in order to pursue fiscal objectives? Tackling measures that contribute to harmful tax competition through the state aid regime instead of relying on the Code of Conduct has the advantage that it is the Commission who may take the initiative without being dependent on the consent of the Council. ${ }^{14}$ On the other hand, the purpose of the state aid regime is to safeguard competitive conditions in the Common Market from distorting state subsidies. Its intention is not to fight harmful tax competition between Member States. ${ }^{15}$ This regime was never designed to address tax competition issues. To the contrary, in the 1950s and 1960s some States were even of opinion that the State aid regime should not apply to any form of fiscal incentive in regard to the sovereignty issue. Yet, as we have seen in the previous chapter certain tax measures - whether harmful or harmless - may contain an element of aid and are for that reason subject to the state aid regime.

The ECOFIN Council specifically agreed not to bar undertakings from entering into harmful tax arrangements as of 2002 if "such arrangements are the subject of an existing Commission decision providing for longer duration within the framework of State aids". This indicates that the Commission can approve of what is regarded to be a 'harmful tax arrangement'. ${ }^{16}$ However, Member States agreed to bar undertakings from approved arrangements as of 2003 even though the Commission considered that it must be possible to continue to apply a tax arrangement for the full period for which it was approved as state aid. ${ }^{17}$ It is rather unlikely that these deadlines will be met. Even if the Member States would be 'willing' to live up to this commitment, they must first come to an agreement on some kind of final list of harmful tax measures.

1998 notice, paragraph 33 .

Code of Conduct, section J.

Once the procedure is initiated, the Council can interfere on the basis of article 88(2) EC upon request of the granting Member State. See chapter II.2.4.

See also VANISTENDAEL (2001), p. 73.

A notification of tax arrangements to the Primarolo Group is not to be considered a formal state aid notification. This would still require a separate notification to the Commission. (CFI T-195/01 and T-207/01 of 30 April 2002, Gibraltar v Commission, not yet published, paragraphs 70 and 122.)

ECOFIN Council of 26-27 November 2000, no. 13861/00, p. 8; corrigendum 13898/00 of 6 February 2001. 
The discussion on harmful tax competition forces the Commission to be careful not to approve new tax incentives that could give rise to controversy, like the (uncontested) approval of regional tax havens in the past such as the Irish IFSC regime. Yet, the Commission cannot be withheld from approving new harmful tax incentives. Even though the Commission has a large discretion in regard to 87(3) objectives, I question its ability to use such discretion to prevent harmful tax competition. Suppose the Commission would decide that a fiscal aid is not compatible with the Common Market merely because it is (potentially) harmful to the tax base of other Member States, a 'negative effect'. Even though such measure should not be tolerated from the perspective of the Code, it is questionable whether the margin of discretion granted to the Commission would allow it to suffice with such motivation.

The Commission must find the equilibrium between benefit (e.g. the Treaty objective served) and distortion again and again. A harmful tax measure may be very effective to stimulate the development of Article 87(3)(a) EC regions, so that the side effects have to be taken for granted to a certain extent even if they are 'harmful'. ${ }^{18}$ The Commission must objectively weigh up the benefits and the harmful effects of a tax incentive brought to light by the Code when assessing the compatibility of a fiscal aid; ${ }^{19}$ this should not be treated as a mere formality. The Commission cannot merely rely on the harmfulness of a tax incentive in order to disapprove of it when it is an efficient (or even the most efficient) method of government aiding to accomplish Treaty objectives set forth in Articles 87(2) and (3) EC. But as long as the 'harmfulness' of a measure is not the primary reason not to approve of an aid that would normally be considered compatible, the Commission will rather be on the safe side. ${ }^{20}$

If the protection of tax bases against harmful competition is to be a task of the Community the power to do so should be explicitly transferred to its institutions. If agreed upon, the Code of Conduct could be made binding by the Council. Subsequently the Commission would be legally restrained of approving harmful tax incentives, because it may not approve of aids that violate other Community legal provisions. $^{21}$

Paragraph $(\mathrm{G})$ of the Code of Conduct provides that it must be assessed whether tax measures used to support the economic development of particular regions are in proportion to, and targeted at, the aims sought in the context of the Community's regional policy. I agree with EAsson (2001b, p. 116) that it makes more sense to have the proportionality assessed under the state aid provisions instead of providing for an independent review, now that these regional aid measures are specifically mentioned in Article 87(3) EC. 1998 notice, paragraph 30.

It seems hard to get the objective, relevant and consistent evidence needed for the annulment of a decision that shows that the Commission decided not to approve of an aid with the sole or decisive purpose to avert harmful tax competition. See also CFI joined cases T-92/00 and T-103/00 of 6 March 2002, Territorio Histórico de Álava and Others v Commission (Ramondín), not yet published, paragraphs 83-85. 


\section{3. 'July 11th, 2001'}

\subsubsection{An Evolution of the Common Market?}

On 11 July 2001 the Commission launched formal state aid investigations into 11 corporation tax schemes from 8 EC Member States. It also urged 4 other Members to discontinue existing fiscal measures that could no longer be justified following the economic changes in the Common Market. ${ }^{22}$ These preferential tax arrangements are granted exclusively to multinational companies or to companies active in the financial services sector. Therefore the Commission has doubts about their compatibility with state aid rules. ${ }^{23}$

The starting of several formal investigations simultaneously seems to have been triggered by the delay in progress of the Code of Conduct. It is rather likely that the Commission would not have taken action in the prospect of an agreement on the withdrawal ("rollback") of harmful tax incentives, including aid regimes now under investigation. Despite of this practical consideration, I disagree with EASSON who argues that if "the Code is to become a dead letter, then the Commission will have no alternative but to enforce the Treaty provisions" on state aid. ${ }^{24}$ As I see it, the Commission never had the option not to enforce state aid provisions once it is aware of any violation, therefore doing so cannot be regarded as an alternative at all. Its conduct not to interfere immediately seemed rather a matter of economy of procedure, of setting priorities and above all of trying to keep out of tax matters as long as Member States can do the job themselves. It is somewhat surprising to see that the Commission was repeatedly asked by the Member States themselves to exercise its powers in the area of fiscal state aids. ${ }^{25}$ In respect to these investigations, Commissioner MONTI stated:

"where tax measures do constitute State aid, the Treaty requires the Commission to take action. There is nothing new in this at all. [...] Whilst action had in the past been taken against tax breaks clearly focused on certain companies (like for instance insurance firms in underdeveloped regions), one cannot deny that some of the more

On 27 February 2002 the Commission decided to open a formal procedure in regard to two existing fiscal aid schemes, because the governments of Belgium (the coordination centre regime) and Italy (the Trieste Financial Services and Insurance Centre) have refused to accept the amendments it proposed on 11 July 2001. See press Release IP/02/325. 
subtle, less obvious advantages had not received enough attention from the Commission in the past." 26

The effect the Code of Conduct had on the Commission's revival in matters of fiscal state aid is considered to be self-evident, although this development raises a fundamental dilemma. The Commission's press release announcing the July 11th investigation states that some of the existing measures now under investigation have been declared not to be state aid or to be compatible aid in the past. These measures "are now, due to the evolution of the Common Market, considered as non compatible state aid." 27 This indicates two changes in policy: (1) some tax measures are now regarded to be state aid though they were no aid in the past, and (2) some approved aids can no longer be regarded as compatible.

As to the first change, it should be considered that a fiscal measure either is state aid or not; it cannot be considered to have become a state aid merely by the adoption of a Code of Conduct that is merely meant to be a "political commitment" ${ }^{28}$ The objective legal concept of state aid is not to be influenced by the practical difficulty that some fiscal aids are subtler and less easy to detect than others. Although the 1999 Procedural Regulation allows for measures to become (existing) aid because of the 'evolution of the Common Market' it is still to be seen whether the ECJ is willing to accept that the developments in the field of harmful tax competition (i.e. the Code) are put on a par with such 'evolution' as to justify the Commission's change of heart. ${ }^{29}$ This concept of 'evolution' is rather dangerous because of the objective nature of the state aid definition; its scope of application must therefore be limited as much as possible. Any 'evolution' must be of such nature that it leads to the objective fulfilment of all elements of the state aid definition where they could not be considered objectively fulfilled in the past.

If a tax measure that is no state aid is to develop into an aid due to changes in the Common Market (read: the Code), this would mean that one or more of the elements of the state aid definition were not fulfilled at first but they are now. It will be rather hard to argue that a change in the Common Market caused a tax benefit to arise were there was none at first. The same will be true for the element of state resources; either such resources were used or they were not. The fact that the Commission (and the Member States themselves) may have failed to detect the Press release IP/01/982 of 11 July 2001.

As VANISTENDAEL (2000, p. 160) illustrates, a tax measure that explicitly aims at reducing the tax revenues of other Member States cannot constitute a 'state aid' for that reason alone, in spite of it being definitely harmful by nature.

Council Regulation EC 659/1999, OJ L 83/1 of 27 March 1999, Article 1(b)(v). As we have seen in chapter II.4.2.2, a measure that was no aid at first is not qualified as 'existing aid' when it has been altered by the Member State in the course of this evolution, neither are measures that have become aid following the liberalisation of an activity by Community law after the date set for liberalisation. 
presence of a benefit or the use of resources cannot be detrimental to these elements being objectively fulfilled. Where the evolution of the Common Market may tip the scale is in regard to the third element, the (threat of) distortion of competition and affecting trade between Member States. Substantial changes in trade relations and competition in certain sectors of industry could have such effect, although we must keep in mind that the third element is rather easily fulfilled once there is some trade and competition in a certain sector. As for the fourth element of selectivity, the fact that the Commission started to identify 'new' kinds of selectivity that it failed to detect previously, such as selectivity in size, cannot be detrimental to the fact that the element was already objectively fulfilled back then.

In regard to the second change I have serious doubts on using the momentum of the introduction of the Code of Conduct as a justification for reviewing the standards for state aid approval. Declaring existing aid incompatible, especially those aids previously approved by the Commission, requires a thorough motivation. In my opinion the Commission cannot limit itself to referring to a 'newly discovered' harmful effect of an aid measure for the reasons set out in the previous paragraph. However, as we will see in paragraph 2 hereafter the Commission may - as part of its periodical review of a measure - revoke its approval because of inefficiency of an aid.

\subsubsection{Transfer Pricing (3)}

From a procedural point of view its interesting to see that in three of the July 11th cases, the Commission opened investigations into special transfer pricing provisions. ${ }^{30}$ As we have seen above, a deviation from the "at arm's length" standard can contribute to an indication of harmfulness of a tax measure. Although departing from this standard could lead to a fiscal benefit for the company involved, it is not possible to rule on a system of transfer pricing in general from a state aid perspective.

If the Commission is to handle transfer pricing issues by the book it would have to look into each specific case in order to determine whether there actually was a benefit or not. In theory each transfer pricing agreement could become the subject of a state aid investigation. However, for reasons of practical expedience the Commission will rather look at special transfer pricing rules or regimes that are used by Member States on a more general level in order to reduce its workload. ${ }^{31} \mathrm{It}$

The German Control and coordination centre regime, OC C 304/2 of 30 October 2001; the Luxembourg Coordination centre regime, OJ C 304/10 of 30 October 2001; the Luxembourg Finance Company regime, OJ C $306 / 2$ of 31 October 2001. In the German case, the tax authorities were prepared not to demand a profit margin of more than $10 \%$ for control and coordination centre activities, even when this would be justified. They would neither object to an incorrect margin, if the profit margin actually used varied between 5 and $10 \%$.

Of course, it is still possible that an interested party turns to the Commission to investigate a favourable transfer pricing regulation of a competitor that it became aware of. 
will try to determine whether such rule will - in principle - lead to a benefit for those entitled to use it or not. If the Commission determines that it does, it may decide to declare such rule incompatible with the common market provided that the other elements of state aid are fulfilled. It will be up to the companies that used such rules to provide evidence of the fact that there was no actual benefit in their case, as an exception to the rule. It must thus be substantiated that the transfer price is at arm's length in order to provide a basis to tax profit as between independent parties. If such evidence is provided for in the course of a formal investigation, the Commission's decision on the special rule should include a specific statement concerning those companies that did not receive an actual benefit at all. ${ }^{32}$ Of course, there will be no need for recovery from those companies afterwards. ${ }^{33}$

\subsection{Structural Measures}

VANISTENDAEL addressed a very fundamental question in regard to fiscal measures within the state aid regime:

"[If] free and fair competition is held to be the objective of the Common Market, why are structural tax measures allowed to distort it?" 34

It should be considered that the Commission will not always perform an individual analysis of this kind upon request in case of aid that has not been notified. In regard to an Italian tax incentive for mergers and asset transfers between banks and banking foundations the Commission ruled the following: "The subject of the Commission's analysis is an aid scheme, i.e. an instrument by which a Member State offers tax advantages to any financial institution that fulfils the conditions laid down in the scheme. The Member State in question did not grant advantages on an individual basis and did not notify each individual case to the Commission. Consequently, given the very nature of the measure, the Commission has to undertake a general and abstract examination of the scheme, both as regards the question of aid and as regards the question of compatibility [...]. The Commission notes that Italy has asked it to analyse each individual case of aid. However, it does not consider that, for this reason alone, it is obliged to do that at this stage of these proceedings. In its view, any such request would have to be accompanied at least by all the information necessary for the Commission to conduct an assessment of each individual case, i.e. all the information that should normally be provided to the Commission in the context of a complete notification of an individual aid pursuant to Article 88(3)." (Decision of 11 December 2001, OJ L 184 of 13 July 2002, p. 27, paragraph 31.) A technical note: if the Commission decides that the special rule contains incompatible state aid and orders recovery, allowing the Member States not to recover from those taxpayers who did not receive an actual benefit, then this would be systematically wrong. Since transfer pricing is concerned with individual cases, the Commission cannot rule on the incompatibility of the special rule as such without declaring that the rule did not contain state aid in certain (categories of) cases. 
Although general fiscal measures (like setting a very low tax rate) may be as harmful as a specific measure, the distortions they cause are kept outside the immediate competence of the Commission as a matter of fiscal sovereignty. Only specific measures can be addressed by the state aid regime and be subject to sanction, although their effect on competition may even be less distorting than of general measures.

When it is accepted that general tax measures may result in the full-scale relocation of certain business activities within the Community from one territory into another, then why is such relocation rejected when stimulated on a sectoral level ${ }^{35}$ It should be considered that certain activities are more attractive than others in regard to potential tax revenue and the size of potential investment and job creation. If the outright competition between Member States on the sectoral level by means of aid schemes were to be allowed, certain Members would be able to attract the more profitable and economically stimulating sectors like high-tech and financing activities while others would be saddled with the less attractive and immobile sectors like agriculture. Without certain regulation in this field, the Community's goal to support the structural reform of regional economies will be crossed.

As VANISTENDAEL argues, making a difference between general and selective measures does not make sense from an economic point of view if looking at distortion of competition. However, it is useful from a political perspective in order to retain some autonomy for Member States to maintain their own tax policy. ${ }^{36}$ Autonomy in setting rate schemes and tax bases - either of a general or selective nature - will continue to create inequality in taxation of market participants in different Member States. This issue will have to be addressed on the political level instead of the executive level, in order to make way for free and fair competition.

\subsection{Articles 94 and 96 EC}

Differences in the structural economic and fiscal policy between Member States have to be targeted by other means provided by the Treaty like Articles 94 and 96 EC. When the Commission is of opinion that a non-selective tax benefit is distorting the conditions of competition within the Common Market, then it may consult with the Member State that grants it. If the Member State is not willing to eliminate such distortion, the Council may adopt (by a qualified majority) a directive proposed by the Commission that addresses the distorting provisions. Article $96 \mathrm{EC}$ is also applicable to measures that fall within the scope of the state aid regime. However, since the Commissions can act more easily and effectively within the scope of the state aid regime without going through the complicated procedure of Article 96 EC, 
it will stick to the first system in practice in regard to selective measures if applicable ${ }^{37}$ In practice, Article $96 \mathrm{EC}$ has not been used in regard to taxation issues.

It has been argued that Article $96 \mathrm{EC}$ might be applicable in case a low tax rate has a distorting effect on competition in the Common Market. ${ }^{38}$ As a result of the Irish IFSC decision referred to in paragraph 1.1, supra, Ireland is set to introduce a standard statutory corporate tax rate of $12.5 \%$. The setting of such low general rate does not fall within the scope of state aid supervision, because it lacks selectivity. If Member States would not even be allowed to compete with their basic tax system of which the statutory rate is an integral part, then what is there to remain of the already limited concept of fiscal sovereignty? This seems to be part of a political discussion on the goals to be set in the area of (corporate) fiscal harmonisation. ${ }^{39}$

Apart from acting against specific distortions in one Member State, the Council has the power to adopt harmonising legislation (with unanimity) to contribute to the establishment and the safeguarding of the functioning of the common market. Such legislation will be applicable all across the Community, and will not be restrained to merely one Member State. On the basis of Article 94 EC the Council among other adopted the parent-subsidiary directive and the merger directive, which have had a substantial impact on direct tax systems in the Community.

\section{Safeguarding National Tax Bases}

\subsection{The Status of an Approved Tax Incentive}

As we have already seen, state aid is prohibited by definition unless it is regarded compatible with the Common Market because of its contribution to one of the goals explicitly set forth in Articles 87(2) and (3) EC.40 I will refer to these compatible aids as 'approved tax incentives' or 'approved preferential tax regimes' in conformity with the Procedural Regulation. ${ }^{41}$ Should the Commission have decided that a

See also Frick (1994), p. 15.

ENGELEN (1999), p. 21.

Without elaborating on the subject of Ireland's proposed $12.5 \%$ tax rate, it should be noticed that the Ruding Committee recommended the preparation of a directive to prescribe a minimum statutory corporation tax rate in all EC Member States in 1992. Back then the Commission 'cautiously welcomed' this recommendation. Due to the 'Council's reaction and the stalemate reached on other initiatives' no further action has been undertaken since. (See annex 1 to the Commission Staff Working Paper 'Company Taxation in the Internal Market', SEC(2001)1681 of 23 October 2001.) More recently, in October 2001 to be exact, the Commission saw no reason to recommend action on the fixing of a minimum corporate tax rate. (Communication 'Towards an Internal Market without tax obstacles', COM (2001)582 final of 23 October 2001, p. 9.)

The following also applies to ad-hoc goals the Council may agree upon in the context of Article 88(2) EC. This Article however will not be discussed explicitly in the remaining of this chapter. 
certain regime does not fall within the scope of the state aid definition of Article 87(1) EC, then it has not been established that such regime pursues a Community goal and there is no 'approval' whatsoever.

Does the approval of a national aid measure give it some kind of community status? It still is a national measure; no approval of any kind by a Community institution can change this. However, upon approval of the Commission it is determined that such aid pursues a goal that is of Community interest.

Approval brings about controversy from a fiscal point of view. This can be explained by taking a closer look at the concept of compatibility of aid. If the Commission would approve of a cash subsidy upon investments in a certain region it could become attractive for companies to invest in that region, instead of investing in the region where they would normally invest without getting a subsidy. ${ }^{42}$ If the same amount would be granted in the form of a fiscal subsidy - by means of investment tax credits, special tax rates and alike - the situation would not be any different. We cannot change the fact that an Euro can only be invested once.

Although subsidies may attract new resources (making companies willing to invest more because of a better return on investment), at least part of the investments that take place in the targeted region would normally take place in other regions or Member States. This kind of cross-border rent extraction reflects the intention of an approved tax incentive and is not to be considered a side effect. The fact that part of domestic profit is transferred to another tax jurisdiction - as a result of moving operations to a new plant or office in the subsidising region - is the logical consequence of the intended shift in activities. Member States could be tempted to act against this rent extraction, in order to protect their revenue. This brings about controversy, since such actions could be irreconcilable with Community policy.

NiCOLAIDES and BILAL point out that state aid rules are still ambiguous in relation to rent-shifting and national state aid policies. If one Member State can increase its economic welfare by means of granting aid at the expense of a welfare loss in other Member States, the aggregated welfare in the Community as a whole could improve even though some Members could be negatively affected. ${ }^{43}$

In non-economic terminology: an approved aid serves a higher Community goal the achievement of which is deemed to serve the interests of all EC Member States. Other Member States must be willing to make certain sacrifices if necessary. The extent to which the interests of the latter Member States are harmed should not weigh up to the common interest served at the level of the Community. I.e. one Member State should be 'willing' to give up part of its tax revenue, since it will be 'compensated' by the fact that its fellow Member State will be enabled to stimulate development in a less developed region through a regional tax incentive. If we take a look at the concept of fiscal sovereignty this kind of reasoning would be unacceptable. We must however face the fact that Member States have committed 
themselves to the development of the Community as a whole and should look beyond national (fiscal) interests.

In the exercising of its discretionary powers, the Commission may decide to live with and implicitly approve of cross-border revenue effects when approving a tax incentive in the better interest of the Community. Even though there is fierce political pressure in this area - arising from the discussion on the Code of Conduct the Commission is not obliged to consider fiscal aids with an evident cross-border revenue effect not to be compatible if such aid serves one or several of the Community objectives set forth in Articles 87(2) or (3) EC. ${ }^{44}$ As long as the Commission considers preferential tax treatment suitable for the pursuing of certain Treaty objectives, such treatment cannot be regarded as unacceptable (i.e. 'abusive') by an individual Member State when it is acceptable from a Community point of view. ${ }^{45}$ We must keep in mind that the Member State's interests are deemed to be served as part of the Community's interests.

Yet, this extreme concept does not make Member States helpless. Any Member State could pursue the annulment of a decision that declares a fiscal aid of a fellow Member State compatible. It should not be argued that the latter should have chosen a cash subsidy instead of a tax incentive per se, but it may be argued that the Commission neglected that a cash subsidy would have been are more effective and less distorting in a certain case. In the past, the Commission approved several regional tax regimes - like the Irish IFSC that intended to attract financial activities into certain regions - even though it could be expected that the actual contribution of financial activities - especially the very mobile activities like financial coordination and banking activities - to the development of the assisted regions would be very limited. Member States failed to seize the opportunity to call upon the ECJ to review the Commission's decisions. It still seems to be politically 'not done' to proceed against a fiscal aid of another Member State, maybe out of fear for a further deterioration of fiscal sovereignty at home. We must also keep in mind that the Court only has the opportunity for a marginal review and that the Commission has very broad discretion in matters concerning $87(3)$ objectives, so that success would not at all be guaranteed.

\subsection{Substance Criteria}

WATTEL stresses that approved fiscal regimes have been one of the motives (and often the only motive) for moving certain financial activities into stimulated regions. ${ }^{46}$ Without a special regime, such activities would not have been transferred to that region on the basis of existing economic conditions. This seems to be beyond

VANISTENDAEL (2000, p. 158) stresses that although the Commission had no doubt that the Irish IFSC regime would result in a considerable loss of revenue in other Member States, it was not considered sufficient reason not to approve the regime. As set forth above, this approval has recently been revoked. 
dispute. However, one might ask whether this makes such regimes eligible for the application of national anti-avoidance provisions. Should the movement of financial activities lead to actual investment in the local economy and the creation of jobs, then the tax incentive would indeed be suited for fulfilling certain community goals. However, in most cases such local economic development is lacking as WATTEL recalls.

Several authors have argued that the Community loyalty principle stands in the way of imposing anti-avoidance legislation on tax incentives that the Commission determined to be compatible. ${ }^{47}$ Unilateral measures that have the potential to interfere with the effectiveness of approved aid constitute a violation of Article $10 \mathrm{EC}$, according to RÄDLER ET AL. ${ }^{48}$ This provision on Community loyalty provides that

\section{"[Member States] shall facilitate the achievement of the Community's tasks. They shall abstain from any measure which could jeopardise the attainment of the objectives of this Treaty."}

Suppose the Commission approves of a $5 \%$ special tax rate for a certain region of a Member State in order to stimulate regional development [i.e. $87(3)$ (a) or (c) compatibility]. If corporations set up a branch there in order to produce and sell certain products from there, then such action may not be confronted with antiavoidance legislation in order not to frustrate the pursued effect of the aid measure. However, if certain activities are routed through that branch only pro forma without any real investment or labour activities in the region - Member States will rather tend to protect their tax base. Yet, it is up to the Commission - and not the Member State - to determine if the aid measure is still compatible with the common market taking account of, for instance, size of investments and job creation. Whenever limited substance entities meet the investment criteria or job creation objectives 'imposed' by the Commission's guidelines, the Commission will probably be satisfied that the fiscal aid measure has a positive effect that attributes to the attainment of a Community objective. If so, then this useful effect - how slight it may be - is not to be tampered with. In such cases, another Member State may not use anti-avoidance legislation only because it regards the special tax rate as a means of diverting tax without any plausible economic (non-fiscal) motive that would justify such investment. It may not rely on its own national anti-avoidance criteria that are more demanding in terms of activity, staff size or the amount of local investment. ${ }^{49}$

DE HOSSON (1996a); SCHERER, in LEHNER / SCHERER (1995), p. 974; RĀDLER / LAUSTERER / BLUMENBERG (1997); КоsсHYK (1999), p. 266.

What the Member State of a parent corporation may do is looking into the transfer prices by which part of the profit from a business process is attributed to the limited substance entity abroad. When these are not at arm's length, then it may apply anti-avoidance provisions as to safeguard the income that would normally 
If local economic development would indeed be lacking as WATTEL recalls, then in my opinion the Member State should bring this issue to the attention of the Commission so that it may revise its decision to approve a certain regime. It can request the Commission to reinvestigate the matter in case unforeseen circumstances or side effects arise after a certain period of time. Preferably, Member States should bring forward any doubts and objections to an aid that is to be approved in the course of a formal investigation. ${ }^{50}$ Yet, as we have seen before, the Commission may actually have considered the revenue effects of a fiscal aid and regard such aid compatible anyway. This is rather unlikely - but not ruled out under the present political climate..$^{51}$ If the Commission fails to act when it is confronted with the lacking contribution to regional development of an approved aid after a certain period of time, it seems that Member States may call upon the ECJ to determine that the Commission has failed to act against inefficient aids, for instance by proposing appropriate measures. ${ }^{52}$ If the ECJ agrees with the Commission's view that a preferential tax regime is still best suited to pursue Treaty objectives, Member States should abide by that ruling and abstain from applying anti-avoidance legislation. If not, they would frustrate the intended result of the preferential fiscal regime.

Nevertheless, in its decision concerning the Trieste centre for financial and insurance services - containing a conditional approval of a partial tax exemption for five years in order to stimulate private investments in Eastern Europe and in the benefit of Trieste - the Commission explicitly stated that its assessment under Articles 87 and $88 \mathrm{EC}$ is "without prejudice to any decisions that other Member States may take under their own tax laws" ${ }^{\prime 3}$ How this is to be interpreted is yet unclear. It seems rather unlikely that the Commission would authorise a fiscal aid to make a region more attractive for financial activities on the one hand, though it would not disapprove of measures from other States that would prevent that from happening on the other, given the fact that approval could only have been granted because the fiscal aid scheme attributed to the attainment of a Community objective.

be attributed to taxable economic processes in that home country. As we will see in chapter IV, the importance of at arm's length taxation is stressed repeatedly in regard to fiscal subsidies on the level of international trade.

Cf. Коsснук (1999), p. 266.

The former approval of the Irish IFSC regime may serve as an example, since it is most likely that the Commission did anticipate on the revenue effects of that scheme.

One could also think of a job creation requirement that turns out to be ineffective. Should most of the jobs actually created be given to people that are attracted from outside the stimulated region (such as employees of a corporation attracted from other countries), the creation of jobs would have no direct effect on reducing the level of local unemployment. 


\subsection{Avoidance of Double Taxation: Tax Exemptions and Tax Credits}

Approved tax incentives will by definition lead to some kind of preferential treatment abroad. When an enterprise chooses to profit from such approved preferential regime, then the incentive from such treatment should not be made undone by additional, compensatory domestic taxes. However, the use of conditioned tax exemptions and tax credits as a means of avoidance of double taxation may turn out to have a neutralising effect.

When an enterprise has a branch abroad it might be entitled to a tax exemption of foreign branch profits, ${ }^{54}$ or it might claim a tax credit for foreign taxes on branch profits and investment income. ${ }^{55}$ Similarly, a parent company that establishes a subsidiary abroad may be entitled to a participation exemption on distributed profits and investment income that are already subject to corporation tax abroad. When tax exemptions are granted on the condition that profits are taxed regularly in the foreign jurisdiction, a preferential tax regime abroad could stand in the way of such exemption.

Tax exemptions should not be withheld from enterprises because of a 'normal treatment' prerequisite if preferential treatment is merely caused by approved tax schemes. Not only would the incentive effect of an approved preferential tax scheme be neutralised, the home state would even be able to gain a profit from its existence. For instance, if a company would normally pay $40 \%$ over 100,000 Euro taxable income abroad and now it would only pay $5 \%$ abroad the home state would exempt this income in the first case but fully tax it $(100,000$ Euro times the domestic tax rate) in the latter case. It seems to me that this would most certainly qualify as a violation of the Community loyalty principle.

In case of a tax credit, it may seem obvious that lowering the tax burden abroad will be compensated by domestic taxation resulting from a lower tax credit. This is inherent to the system of avoiding double taxation. If foreign tax incentives will be neutralised in the home state the stimulant to apply for such incentive is likely to be minimal. As a result of the functioning of the credit system the use of an approved foreign incentive would rather result in an increase in revenue at home.

Granting an exemption in cases of approved preferential treatment will not be at the cost of the home state, because it would normally grant such exemption. Neither will granting the normal amount of tax credit to which an enterprise would be entitled if its subsidiary or permanent establishment would not be subject to an approved preferential tax regime abroad. The amount of credit to be granted by the home state would remain the same. So it is possible to safeguard the foreign incentive without sacrificing domestic revenue, apart from the income base that moves as a result of reallocation of activities. I do not deny that there is a certain necessity to limit the granting of tax exemptions in regard to preferential tax 
treatment abroad. The reduction of a tax credit in case less tax is levied abroad is also self-evident. Yet, we must take account of the special status of approved preferential tax regimes.

The system of avoidance of double taxation has undoubtedly a useful fiscal purpose, but we must face the fact that this system may have some undesirable side effects in regard to state aids. In my opinion, a Member State should take approved tax incentives into consideration as a matter of loyalty and not try to undo such incentive by collecting additional taxes itself. Its system of avoidance - be it an exemption or credit system - should be adjusted accordingly.

\subsection{CFC Legislation ${ }^{56}$}

The issue on tax exemptions and tax credits is of special interest in regard to Controlled Foreign Company ('CFC') legislation. CFC provisions enable a country to tax certain foreign profits from controlled subsidiaries at the level of the parent, in case of tax evasion or tax avoidance. This can be done by attributing the subsidiary's profits to the parent by fiction or by withholding certain exemptions or credits if necessary. There are three main types of CFC legislation. ${ }^{57}$

The first is based on a jurisdictional designated list approach. It applies when subsidiaries are established in certain designated territories that are deemed to have an unacceptable tax system (i.e. very low effective taxation) from the home state's view. It is unlikely that this approach will cause compatibility issues in regard to state aid when used by an EC Member State. Unless, of course, (a region of) another Member State is placed on such list merely as a result of approved preferential tax schemes when - without such scheme - the normal tax scheme would be satisfactory to exclude the Member State from such list.

The jurisdictional comparable tax approach is the most dangerous in regard to state aid. It compares whether the amount of tax payable abroad is less than a certain percentage of taxes due at home over the same profit, or whether the effective or nominal tax rate is set below a certain acceptable level from the view of the home state. In making any comparison, the effect of an approved tax incentive should be taken into consideration for the same reasons provided for tax exemption and tax credit schemes in the previous paragraph. Of course, the tax authorities cannot do so without the taxpayer providing the necessary information. But once the necessary information on its foreign tax treatment is provided, the tax authorities of the home state should act accordingly. A Member State should not apply CFC legislation to an approved preferential tax regime abroad, if the normal treatment abroad (i.e. the treatment without the approved incentive) would lead to a comparable amount of taxes payable and thus to the non-application of CFC legislation. When it would be allowed to apply its CFC legislation as a result of approved favourable treatment alone, then the intended useful effect of the fiscal aid for the benefit of the Community would be fully or partially diminished. 
In the transactional approach, CFC legislation will be applied to certain types of income regardless of their source. In general, genuine business income from industrial or commercial activities is exempt from such CFC regime. ${ }^{58}$ But countries that do so often limit the types of business that are to be exempt. ${ }^{59}$ Suppose business income from banking or investment services are excluded from the exemption (thus subject to the CFC regime), then the Commission's consent to stimulate the development of such activities in certain regions of the Community could be interfered with. However, if this CFC legislation applies to all foreign banking or investment services regardless of their tax treatment abroad such regime seems acceptable from a state aid point of view. It would be neutral towards any approval.

Even though it may seem necessary to stop tax avoidance (or better: tax abuse) from a fiscal point of view, we must take a look at the bigger picture. If the Commission approves a special tax regime as a method to grant aid, anti-taxavoidance measures from other Member States could jeopardise the attainment of the Community's social and economic goals. I agree with DE HOSsON that it should be irrelevant whether anti-tax-avoidance provisions are an integral part of the national fiscal system or not. Even such general provisions may stand in the way of pursuing Community objectives. ${ }^{60}$ It should not matter whether these provisions are at the very heart of the general tax system or not, since it is the result that counts in the end. I do not propose that anti-tax-avoidance provisions like CFC regimes should be abandoned. Yet, it should remain possible to deviate from such provisions when the useful effect of approved state aids is at stake.

\section{Fundamental Freedoms}

When exercising its authority in regard to state aids, the Commission may not approve of any aid that would violate other EC Treaty provisions having direct effect. ${ }^{61}$ These include the free movement of workers (Article $39 \mathrm{EC}$ ), the right of establishment (Article $43 \mathrm{EC}$ ), the free movement of capital and payments (Articles 56-60 EC), the free movement of goods (Article $23 \mathrm{EC}$ ) and the free provision of services (Article $49 \mathrm{EC}$ ). Therefore, an approved fiscal aid may not constitute a violation of these fundamental freedoms, which have played an important part in the development of tax systems in the EC Member States..$^{62}$ Two examples:

Should there be requirements upon which the CFC legislation will not apply (such as 'adequate taxation $\mathrm{abroad}^{\prime}$ ) then the problems discussed in regard to the two jurisdictional approaches must be faced. OECD report on "Controlled Foreign Company Legislation", 1996, pp. 69-70.

DE HOSSON (1996b), p. 1864.

ECJ C-156/98 of 19 September 2000, Germany v Commission, ECR 2000, 1-6857, paragraph 78; ECJ 73/79 of 21 May 1980, Commission v Italy (Sovrapprezzo), ECR 1980, 1533, paragraph 11; ECJ C-225/91 of 15 June 1993, Matra v Commission, ECR 1993, 1-3203, paragraph 41.

Should the Commission erroneously consider an aid 'compatible with the common market' though it violates Treaty provisions having direct effect, this may of course provide grounds for the annulment of the 
When deciding not to approve a German fiscal aid scheme for businesses in the New Länder and the Western part of Berlin the Commission considered that the scheme demanded that eligible corporations have their business seat and management in that region. Since a local branch office or a permanent establishment of a corporation seated elsewhere in the Community would not be entitled to the aid, the Commission could not grant approval since it would violate the freedom of establishment. ${ }^{63}$

Two Basque tax reduction schemes were only available to enterprises that exercised all their activities from within the Basque Province. Firms from other Member States would thus not be eligible for the tax reduction scheme if they would continue trading from outside the Basque territory. One of the schemes also required that the enterprise should have its head office in that Province. Apart from making the tax scheme selective, these restrictions also infringed the right of establishment. Consequently, the aid schemes could not be declared compatible, ${ }^{64}$ regardless of the effect it may have had on the development of the Basque Province.

It is not being said that the aforementioned regimes would not have had a favourable effect on regional development. However, the need to establish company headquarters in the assigned region or to carry out all activity from within a region made them too restrictive. When companies would create jobs and satisfy minimum investment criteria upon establishment of a branch office, why then should they not be eligible for investment incentives? What it comes down to is that the restrictions imposed were not strictly necessary to stimulate regional investment. Therefore, the Commission could not approve of these incentives.

decision. Such erroneous approval cannot provide any protection against Court proceedings in regard to violations of EC provisions other than those of the state aid regime. 
Limitations on the Design of Direct Tax Systems 


\section{THE WTO SUBSIDIES FRAMEWORK}

\section{The SCM Agreement}

The Agreement on Subsidies and Countervailing Measures (the 'SCM Agreement') is one of the Multilateral Agreements on Trade in Goods that are an integral part of the Agreement Establishing the World Trade Organization (the 'WTO'). The main objective of this SCM Agreement is to limit the use of subsidies in international trade, in order to create a more even level playing field between competitors from different WTO Member States on the international market. ${ }^{1}$ It also provides a basis for taking countermeasures in order to compensate for the 'unjustified' use of tradeaffecting subsidies by other countries.

The SCM Agreement offers two almost independent systems to address subsidies: subsidy regulation ("track $\mathrm{II}^{\prime \prime}$ ) and countervailing duties ("track $\left.\mathrm{I}^{\prime \prime}\right)$. This chapter will mainly focus at track II, in order to make a comparison with the state aid regime in chapter $\mathrm{V}$. However, in order to give a more complete view of subsidy regulation from a WTO perspective a brief description of track I will also be provided. I will discuss tracks II and I in the order in which they appear in the SCM Agreement. Their reverse numbering is a legacy from pre-1995 subsidy regulation.

The definition of a 'subsidy' in WTO terms will be discussed in paragraph 2. The subsidy regulation framework ("track II") will be presented in paragraph 3 . The different categories of subsidies will be discussed there separately. The scope of the obligation to withdraw subsidies will be addressed in paragraph 4. Paragraph 5 will discuss the EC-US disputes on fiscal export subsidisation in regard to the US "Domestic International Sales Corporation" regime, its successors the "Foreign Sales Corporation" regime and the "Extraterritorial Income Exclusion" Act as well as some tax regimes from EC Member States. The system of unilateral countervailing duties ("track I") will follow next in paragraph 6. Tax-related issues of such countervailing duties will be illustrated in paragraph 7. Paragraph 8 will 
briefly address the issue of introducing unilateral counter-subsidies without recourse to SCM Agreement procedure.

The SCM Agreement operates in the field of trade in goods only. Some demonstrable impact on the trade of goods is a prerequisite for entering the arena of the SCM Agreement, which limits the kind of tax incentives it can interfere with. Its rules do not (yet) apply to the cross-border rendering of services. These incentives fall within the scope of the General Agreement on Trade in Services. Services related subsidies are addressed in paragraph 9 separately.

\section{The Definition of a Subsidy}

The importance of the SCM Agreement in the field of direct taxation is often underestimated. However, in the last couple of years a number of bilateral and multilateral disputes have arisen concerning the compatibility of tax measures with this international framework, which began to draw the attention to it that it deserves. In order to be subject to this framework, there must be a 'subsidy'. The subsidy definition consists of two separate legal elements. ${ }^{2}$ First, there must be a financial contribution by the government (or any public body within the territory of a WTO Member State) to an actor in trade, or at least a potential financial contribution of such kind. ${ }^{3}$ In regard to fiscal subsidies it mav, hy their natiure, he ressumed that. they are (to be) granted by the government (either at a federal, national or local level). As we have seen in previous chapters, tax incentives may contain a subsidy element (in EC terms an 'aid'). The SCM Agreement explicitly states that fiscal incentives like direct tax credits are to be considered a 'financial contribution' for the purpose of its subsidy definition by referring to 'government revenue that is otherwise due is foregone or not collected', thus i.e. tax expenditure. ${ }^{4}$

Apart from the element of a financial contribution by the government, the SCM Agreement's subsidies definition requires that a benefit is thereby conferred. The term 'benefit' does not have an abstract meaning; it indicates that the beneficiary or the recipient should actually have received something. ${ }^{5}$ It is necessary to determine whether the recipient itself is placed in a more advantageous position. The financial contribution by the government should thus make the recipient better off than he would otherwise have been in the absence of such contribution. ${ }^{6}$ In my opinion, this

Appellate Body Report, Brazil - Export Financing Programme for Aircraft, WT/DS46/AB/R, adopted 20 August 1999, paragraph 157; Panel Report, United States - Measures Treating Exports Restraints As Subsidies, WT/DS194/R, adopted 23 August 2001, paragraphs 8.40 and 8.73 .

Article 1.1(a)(1) SCM Agreement; Panel Report, Brazil - Export Financing Programme for Aircraft, WT/DS46/R, adopted as modified by WT/DS46/AB/R, 20 August 1999, paragraph 7.13.

Appellate Body Report, Canada - Measures Affecting the Export of Civilian Aircraft, WT/DS70/AB/R, adopted 20 August 1999, paragraph 154. 
indicates that it is irrelevant whether or not a tax advantage merely intends to lower the tax burden of an enterprise to a level comparable to that of his competitors abroad in order for a benefit to exist.

The rationale behind the SCM Agreement is not to avoid net cost to government, but its purpose and objective is to establish a multilateral discipline on the premise that some forms of government intervention distort international trade or have the potential to do so ${ }^{7}$ The inquiry into the presence of a subsidy must therefore focus on whether some kind of benefit is conferred to the recipient, ${ }^{8}$ which would be able to cause such distortion. Thus even though there may be a cost to govemment (in regard to fiscal subsidies: a revenue loss) it may not simply be assumed that this will result in or be the cause of an actual benefit. Vice versa, even if a financial contribution would not result in net cost to government in the end there may still be a benefit as such.

\section{Track II: Classification of a Subsidy}

\subsection{Twe Types of Subsidies}

JACKSON describes Track II as a set of rules providing "substantive international obligations against the use of subsidies that may affect international trade". ${ }^{10}$ Two types of subsidy are defined in this part of the SCM Agreement: prohibited subsidies and actionable subsidies. The limitations imposed on tax incentives in the field of trade depend on the qualification of such incentives. The material and procedural peculiarities of each category will be set forth hereafter.

Until 31 December 1999 there also was a third type of subsidy, that of nonactionable subsidies. ${ }^{11}$ These subsidies were meant to serve a special purpose (the assistance of research activities, of disadvantaged regions or of the adaptation of facilities to new environmental requirements). If such subsidy met a number of criteria specified in the SCM Agreement, it could - in principle - not be the subject of an actionable subsidy procedure. This procedure will be described hereafter. Since no agreement could be reached on extending the application of these criteria, the category of non-actionable subsidies no longer exists. ${ }^{12}$ The original

Panel Report, Canada - Measures Affecting the Export of Civilian Aircraft, WT/DS70/R, adopted as modified by WT/DS70/AB/R, 20 August 1999, paragraph 9.119-9.120.

Appellate Body Report, Canada - Measures Affecting the Export of Civilian Aircraft, WT/DS70/AB/R, adopted 20 August 1999, paragraphs 149-161.

Panel Report, Canada - Measures Affecting the Export of Civilian Aircraft, WT/DS70/R, adopted as modified by WT/DS70/AB/R, 20 August 1999, paragraph 9.115.

JACKSON (1997), p. 281.

11 See the former Articles 8 and 9 of the SCM Agreement and Luja (1999a), pp. 209-210.

12 See Article 31 SCM Agreement and the WTO's Annual Report 2001, p. 63. A major part of the discussion on extension in the WTO's Committee on Subsidies and Countervailing Measures is reflected in WTO 
categorisation was known as the red, yellow (amber) and green system or the black, grey and white system.

\subsection{Prohibited Subsidies}

\subsubsection{Prohibited Subsidies Classification: Export}

Prohibited subsidies include export stimulating subsidies and import-substituting subsidies. An export-related subsidy is defined as a subsidy,

"contingent, in law or in fact, whether solely or as one of several conditions, upon export performance". ${ }^{13}$

Recall that only the export of goods is meant and not the export of services. Annex I to the SCM Agreement provides an illustrative list of subsidies that are deemed to be export subsidies. ${ }^{14}$ Besides non-fiscal subsidies, this list includes the full or partial exemption, remission (including the refund or rebate of taxes) or deferral of direct taxes specifically related to exports. The term direct taxes includes not only income taxes and corporation taxes, but also to taxes on wages, interests, rents and royalties and taxes on the ownership of real property. ${ }^{15}$

As to tax incentives that are de jure contingent upon export performance, this relation can be demonstrated on the basis of the words of the relevant regulations. ${ }^{16}$ An incentive may also be de jure contingent if the condition of export is "clearly, though implicitly" present; export contingency may be implicated from the words actually used in the relevant regulation. ${ }^{17}$

Demonstrating de facto export contingency of a tax incentive is not as simple. The tax incentive must be tied to actual or anticipated exportation or export earnings. ${ }^{18}$ I.e. the existence of a subsidy should depend on export performance. A relation of conditionality or dependence must therefore be demonstrated. Merely

documents G/SCM/M/22, circulated 17 February 2000, and G/SCM/M/24, circulated 26 April 2000. Attempts are being made to get the category of non-actionable subsidies reinstated for subsidies granted by developing countries.

Article 3.1 (a) SCM Agreement.

The list of alleged export subsidies in the Annex to the SCM Agreement is not of an exhaustive nature. See Panel Report, Brazil - Export Financing Programme for Aircraft (Recourse by Canada to Article 21.5 of the DSU), WT/DS46/RW, adopted as modified by WT/DS46/AB/RW, 4 August 2000, paragraphs 6.30-6.31.

Item (e) of Annex 1 and footnote 58 to the SCM Agreement.

Appellate Body Report, Canada - Measures Affecting the Export of Civilian Aircraft, WT/DS70/AB/R, adopted 20 August 1999, paragraph 167.

Appellate Body Report, Canada - Measures Affecting the Automotive Industry, WT/DS139/AB/R, WT/DS142/ AB/R, adopted 19 June 2000, paragraph 100.

Footnote 4 of the SCM Agreement. 
demonstrating that the granting government anticipated (or knew) that its subsidies would result in export is insufficient to establish such a relationship. ${ }^{19}$ As the Appellate Body recalls:
"A subsidy may well be granted in the knowledge, or with the anticipation, that exports will result. Yet, that alone is not sufficient, because that alone is not proof that the granting of the subsidy is tied to the anticipation of exportation." 20

The existence of this relationship must be inferred from all relevant facts; which facts are relevant will depend on the circumstances of a case. ${ }^{21}$ The export orientation of a recipient may be relevant, but it is by itself insufficient to conclude that a subsidy is tied to exportation or export earnings.22 For de facto export contingency to be fulfilled, it is not necessary that the recipient himself had a reasonable knowledge of the existence of such contingency since the prohibition focuses on the granting WTO Member State. ${ }^{23}$

Footnote 59 to the SCM Agreement contains some very important information on the relationship between export subsidisation and the avoidance of double taxation. Although a tax exemption or tax credit (in regard to profits out of export transactions) could qualify as a subsidy under the Illustrative list,
"it is not intended to limit a Member from taking measures to avoid the double taxation of foreign-source income earned by its enterprises or the enterprises of another Member." 24

Should taxes be exempt, remitted or deferred as part of the normal system of avoidance of double taxation on foreign-source income, then this is not prohibited for the mere fact that it may also affect export-related income from abroad. Be that as it may, it seems unlikely that the parties to the SCM Agreement were planning on giving States carte blanche by providing an exemption for measures to avoid double taxation. It seems to me that parties merely wanted to recognise that the granting of a tax exemption or a tax credit is an accepted method to avoid double taxation. In

Appellate Body Report, Canada - Measures Affecting the Export of Civilian Aircraft, WT/DS70/AB/R, adopted 20 August 1999, paragraphs 171-172; Appellate Body Report, Canada - Measures Affecting the Export of Civilian Aircraft (Recourse by Brazil to Article 21.5 of the DSU), WT/DS70/AB/RW, adopted 4 August 2000, paragraphs 47-48. Appellate Body Report, Canada - Measures Affecting the Export of Civilian Aircraft, WT/DS70/AB/R, adopted 20 August 1999, paragraphs 172-173. Ibid., paragraph 169. Ibid., paragraph 173; see footnote 4 to the SCM Agreement. Ibid., paragraph 170 . Footnote 59 to the SCM Agreement. 
my opinion, any diversion from the method normally applied to avoid double taxation in a State (either on the basis of treaties or unilateral measures) could still qualify as a prohibited subsidy.

More specifically, a tax exemption or tax credit for income that has already been taxed abroad is not regarded to be a subsidy; a tax exemption that is merely available to certain categories of income could be. The question still remains what is to be regarded as a category of income. Some countries use the exemption as well as the credit system to avoid double taxation. The first is often used for labour income and entrepreneurial or corporate income from a foreign source, while the latter is used for foreign interests and dividends. A distinction between these kinds of income does not give rise to concern. Within these categories of income however, a further distinction could be troublesome. If a State would merely grant a tax credit (or no kind of avoidance at all for that matter) in regard to entrepreneurial income, while granting a tax exemption for entrepreneurial income from export activities then such distinction is unlikely to fall under the protection of measures to avoid double taxation as set forth in footnote 59 . This issue will be further illustrated in paragraph 5.2, infra.

Apart from granting some leverage in the field of avoidance of double taxation, footnote 59 further states:

"The Members reaffirm the principle that prices for goods in transactions between exporting enterprises and foreign buyers under their or under the same control should for tax purposes be the prices which would be charged between independent enterprises acting at arm's length. Any Member may draw the attention of another Member to administrative or other practices which may contravene this principle and which result in a significant saving of direct taxes in export transactions."

The setting of a price that would not be at arm's length could lead to non-taxation of part of the profit on export related transactions that would normally be attributable to activities within the territory of a Member State. This could result in saving of taxes on export profit, which may thus give rise to a subsidy. I.e. if part of the profit from an export transaction is incorrectly attributed to activities outside national tax jurisdiction that part of profit will not be taxed domestically. Most probably, this part will neither be taxed abroad when the tax authorities there merely tax the amount of profit that would normally be attributable to local activities (thus leaving the surplus profit untaxed) ${ }^{25}$ It must be noticed that a slight deviation of the at arm's length price may be able to escape from the export subsidy prohibition, since the footnote states that there must be a significant savings of direct taxes. These transfer-pricing issues may turn out to be a rich source for future subsidy disputes. ${ }^{26}$ 
The FSC case that will be discussed in paragraph 5.2. hereafter may serve as an example thereof; the issue of transfer pricing will be addressed there in more detail.

\subsubsection{Prohibited Subsidies Classification: Import}

A prohibited subsidy related to import substitution is defined as a subsidy

"contingent, whether solely or as one of several other conditions, upon the use of domestic over imported goods" ${ }^{27}$

It may either be a contingency in law (de jure) or in fact (de facto). ${ }^{28}$ There is no illustrative list for import-substituting subsidies. However, tax incentives that relate to the use of goods produced at home instead of those imported may be subject to this prohibition like any other kind of subsidy.

As to import substitution, the mere fact that it is required that a certain percentage of the value added to goods must be of domestic origin does not lead necessarily to contingency upon the use of domestic over imported goods. Such requirement may be met by elements like labour costs, overhead, depreciation and other expenses without the need to use goods of domestic origin. The latter brings back to mind that the SCM Agreement is only meant to address subsidies related to goods and not to other kinds of activities like labour. As the Appellate Body recalls, whether the recipient of the subsidy is able to meet the value-added requirement without using goods of domestic origin depends on the percentage set. ${ }^{29}$

For instance, suppose a subsidy is available when at least $25 \%$ of the value added to certain goods is of domestic origin. A finished product has a value of 20 . If we assume that the value of the input of domestic labour is 5, the requirement would be fulfilled without it being necessary to use goods of domestic origin. However, if the percentage would be set on $75 \%$ it will be very hard to contain that such requirement can be met by using domestic labour alone especially when the finishing of the product concerned mainly depends on the input of goods (supposing that the cost of overhead and depreciation are negligible). In this case the use of domestic goods will rather be a necessity than a mere possibility to attain the required percentage. ${ }^{30}$ another are substituted by subsidised goods originating from within that other Member. 


\subsubsection{Prohibited Subsidies Procedure ${ }^{31}$}

Article 3.2 of the SCM Agreement states that a WTO Member "shall not grant nor maintain" prohibited subsidies. The obligations arising therefrom are evident; Members must abolish existing prohibited subsidies and refrain from granting new prohibited subsidies. Article 4 of the SCM Agreement provides the specifics of how to handle a dispute that may arise in regard to prohibited subsidies. The general framework of dispute settlement is set forth in the Dispute Settlement Understanding (the 'DSU'). Hereinafter, the prohibited subsidy procedure will be outlined. ${ }^{32}$

If a WTO Member should allegedly grant prohibited subsidies, any other Member may request consultations with such other Member. This request should contain the available evidence in regard to the existence and nature of the alleged subsidy. The consultation phase serves to facilitate a resolution of any trade dispute by dialogue between parties without making it necessary to start full proceedings. If both Members cannot agree upon a solution (i.e. the abolishment of the subsidy or a determination that there is no WTO inconsistent subsidisation) within 30 days, the requesting Member may refer the matter to the WTO's Dispute Settlement Body (hereinafter: the 'DSB'). ${ }^{33}$ From the onset, it should be mentioned that parties may agree to extend these rather stringent time periods, ${ }^{34}$ which is actually common practice.

The DSB will immediately establish a dispute settlement panel. ${ }^{35}$ This panel may request the assistance of a group of experts that should give a binding decision on whether the alleged measure is a prohibited subsidy. The panel is to submit its final report within 90 days after its composition and the setting of the terms of reference. If it is determined that a measure actually contains a prohibited subsidy, it will be recommended that it is to be withdrawn without delay. Even though withdrawal should take place "without delay" the panel itself will specify a reasonable time limit to do so. ${ }^{36}$ This period may vary depending on the specifics of the case. In practice, the panel will determine the shortest period possible; a period of 90 days has frequently been used. However, in the FSC case (to be discussed in

Unless otherwise stated, these procedural matters are set forth in Article 4 SCM Agreement.

Details on how to proceed can be found in the DSU and will not be discussed here. It should be mentioned that the time periods used in a prohibited subsidies procedure are normally half of those used in normal dispute settlement procedures (Article 4.12 SCM Agreement).

Parties can - of course - still reach a mutually satisfactory solution, even when the matter has already been referred to a panel as discussed hereafter. (Articles 3(7), 11 and 12(7) DSU.)

MONNIER (2001, p. 825) refers to this time limit as a 'safety-valve' that was inserted by the negotiators of the WTO Agreements, because the zero delay standard may have seemed somewhat unrealistic. 
paragraph 5.2, infra) the time-limit was set to approximately one year to end on the first day of the following fiscal year being the first practicable date. ${ }^{37}$

The DSB will adopt the report within 30 days after submission, unless one of the parties decides to appeal the report or it is decided by consensus not to adopt the report. Within 30 days of the notification of appeal, the Appellate Body will provide its decision. ${ }^{38}$ This Appellate Body report will be adopted by the DSB and unconditionally accepted by the parties involved, unless the DSB decides by consensus not to adopt the report within 20 days following its submission.

Prompt compliance with the recommendations in adopted DSB reports is essential to ensure the effective resolution of any dispute. ${ }^{39}$ If there is disagreement as to compliance with these recommendations, the complaining Member may resort to a panel again (when possible the original panel) based on Article 21.5 of the DSU. This so-called 21.5 panel must then determine whether these recommendations have been complied with within 45 days. For instance, a panel may be called upon when it is in dispute that revision of a subsidy scheme is sufficient in order to take away an export contingency. ${ }^{40}$ If the recommendations from the report(s) adopted by the DSB are not followed within the 'reasonable' time-limit specified by the panel, the complaining Member may be granted authorisation by the DSB to take appropriate measures to counter the subsidy temporarily until such time the recommendations are complied with. ${ }^{41}$ The burden of proof in regard to the non-implementation of the decision falls on the complaining Member.

In order to determine what level of countermeasures is appropriate (i.e. not disproportionate in light of the subsidy being prohibited), the defending Member can request that an arbitrator may do so. ${ }^{42}$ Countermeasures that correspond with the total amount of subsidy have been considered appropriate, ${ }^{43}$ they may not only

See also MONNIER (2001), p. 832.

The Appellate Body may extend this time limit up to 60 days in total by written notification to the DSB. Article 21(1) DSU.

Appellate Body Report, Canada - Measures Affecting the Export of Civilian Aircraft (Recourse by Brazil to Article 21.5 of the DSU), WT/DS70/AB/RW, adopted 4 August 2000, paragraph 40.

1 The time limit starts when the DSB adopts the panel and - if available - Appellate Body report. Authorisation is granted unless the DSB decides by consensus not to do so.

Article 4.11 SCM Agreement in reference to Article 22(6) DSU.

Decision by the Arbitrators, Brazil - Export Financing Programme for Aircraft (Recourse to Arbitration by Brazil under Article 22.6 of the DSU and Article 4.11 of the SCM Agreement), WT/DS46/ARB, circulated 28 August 2000, paragraph 3.60. This decision concerned a case where the actual harm inflicted by a Brazilian subsidy was higher than the amount of subsidy in which Canada itself proposed countermeasures up to the amount of subsidy. Also see paragraph 5.2.7, infra, concerning the decision by the Arbitrator in United States - Tax Treatment For "Foreign Sales Corporations" (Recourse to Arbitration by the United States under Article 22.6 of the DSU and Article 4.11 of the SCM Agreement), 
be imposed on the subsidised goods imported but also on the import of other (nonsubsidised) goods originating from the subsidising WTO Member State. Countermeasures - such as the suspension of application of tariff concessions on goods imported from the subsidising Member - are normally not allowed under the WTO's General Agreement on Tarrifs and Trade 1994 (hereinafter: the GATT), therefore DSB authorisation is needed. I would like to stress that countermeasures are meant to be a last resort; it is not the objective of the SCM Agreement procedure to end up with such measures at all. To the contrary, prompt compliance is still the primary objective.

\subsubsection{Judicial Standards in the Dispute Settlement Process}

Parties may be relatively assured that the panel and Appellate Body process takes place on the basis of judicial standards. There seem to be sufficient safeguards in order to assure a proper quasi-judicial process. WEBER and MOOS have looked into some aspects of the procedure: ${ }^{44}$

First, they addressed the independence and objectivity of those taking any decision. Panel Members should be selected (ad hoc) with a view on their independence from national governments; they serve in their individual capacities and may not receive any instructions from parties or be influenced by them. ${ }^{45}$ Their independence is assured by the confidentiality of panel deliberations and by keeping individual opinions of members anonymous. ${ }^{46}$ Members of the Appellate Body may not participate in the consideration of a dispute when this would cause a conflict of interest. ${ }^{47}$ I would like to add that citizens of Members that are party to a dispute cannot serve on a panel unless parties agree otherwise. ${ }^{48}$ Moreover, Members of the Appellate Body should be unaffiliated with any government. They are appointed by the DSB for a four-year term. ${ }^{49}$

Second, WEBER and MOOS looked at the issue of fair trial. There are stringent time limits set for the duration of procedures. This may cause lack of sufficient time for thorough deliberations in WEBER and MOOS' view. A possibility of appeal in regard to legal questions is available. In WEBER and MOOS' view, the down side of confidentiality is lack of transparency in regard to deliberations. But then, it seems to me that the publication of extensive and detailed reports does create some transparency after all.

WT/DS108/ARB, circulated 30 August 2002, where the countermeasures were set to match the level of government expenditure on a special tax regime.

WEBER / MOOS (1999), pp. 231-234.

Article $8(2)$ and $8(9)$ of the DSU.

Article 14(1) and 17(11) of the DSU

Article 17(3) DSU.

Article 8(3) DSU.

See Articles 17(2) and 17(3) DSU. An Appellate Body Member may be reappointed once. 
Third, WEBER and MoOs looked at the quality and consistency of decisions. They concluded that even though panel and Appellate Body reports are only binding to the parties in the dispute, previous decisions are taken into consideration to a high degree. They also take account of general principles of international law. In regard to quality, I would like to add that the Appellate Body should consist of "persons of recognized authority, with demonstrated experience in law, international trade and the subject matter of the covered agreements generally." 50

\subsubsection{Developing Countries}

Subsidies can play an important role in the economic development of developing countries. The SCM Agreement regime is therefore less restrictive in regard to developing countries. The absolute prohibition on export subsidies is not applicable to least-developed countries (as designated by the United Nations). ${ }^{51}$ For other developing countries, three conditions must be met in order to fall outside the scope of application of the prohibition on export subsidies. ${ }^{52}$

First, there must be a phase-out of existing export subsidies within an 8-year period ending 1 January 2003. The WTO's Committee on Subsidies and Countervailing Measures may extend this period upon request of the developing country when justified, after an examination of relevant economic, financial and development needs. How and at what speed a "phase-out" has to take place has not been specified. Yet, a progressive phase-out is preferred. The mere fact that a developing country did not engage in a phase out during the first four years of the transition period can not lead to the conclusion that it will not do so in time after all. ${ }^{53}$ As a panel described:

"While developing countries certainly would be well advised to plan as far as possible in advance for the elimination of their export subsidies, their failure to do so does not in itself demonstrate that the required elimination will not occur." 54

Fact is that prohibited export subsidies must be fully abandoned before the deadline except for those countries getting the derogation. When a developing country enters into legally binding commitments to provide export subsidies after the deadline,

Article 17(3) DSU.

Annex VII to the SCM Agreement provides a list of countries that will be treated as least-developed countries as long as their GNP per capita is below 1.000 USS per annum.

Article 27 SCM Agreement; Appellate Body Report, Brazil - Export Financing Programme for Aircraft, WT/DS46/ AB/R, adopted 20 August 1999, paragraph 140.

Panel Report, Brazil - Export Financing Programme for Aircraft, WT/DS46/R, adopted as modified by WT/DS146/ AB/R, 20 August 1999, paragraph 7.81.

Ibid., paragraph 7.83 . 
without applying for an extension of the transition period, it may be concluded that it will not comply with its obligation to phase out its export subsidies in time..$^{55}$

The second condition is that there may be no increase in the level of export subsidies during the transition period as of the date of entry into force of the WTO Agreement. ${ }^{56}$ The proper benchmark for this condition is actual expenditure in the year immediately preceding this date and not the budgeted amount. ${ }^{57}$ Third, export subsidies must be eliminated prior to the deadline when export subsidies are no longer consistent with the development needs of the developing country concerned. ${ }^{58}$

So in order for another WTO Member to be successful in its pursuit of having an export subsidy of a developing country withdrawn, it must first demonstrate that not all of these conditions are met. ${ }^{59}$ As for import-substituting subsidies, they should have been abandoned by developing countries by 1 January 2000 . For leastdeveloped countries, this deadline has been set on 1 January 2003.60

\subsection{Actionable Subsidies}

\subsubsection{Actionable Subsidies Classification}

Apart from prohibited subsidies, there is a category of services that may have certain effects on international trade and are therefore to be abolished. However, unlike outright export subsidies and import-substituting subsidies their effect on trade is less evident. A subsidy may be subject to procedural and material action, if it is specific and has an adverse effect on the interests of other WTO Members. Both elements need to be present and a causal relationship should exist between them in order to determine the presence of an actionable subsidy.

.

.

Ibid., paragraph 7.85

Footnote 55 to the SCM Agreement provides that, in case a developing country had not been granting export subsidies at the time the WTO Agreements entered into force, its level of export subsidies granted in 1986 will be taken as a benchmark. (Also see Panel Report, Brazil - Export Financing Programme for Aircraft, WT/DS46/R, adopted as modified by WT/DS46/ AB/R, 20 August 1999, paragraphs 7.62.)

Appellate Body Report, Brazil - Export Financing Programme for Aircraft, WT/DS46/AB/R, adopted 20 August 1999, paragraph 196(c)(i). WT/DS146/ AB/R, 20 August 1999, paragraph 7.90.

Ibid., paragraph 7.56; Appellate Body Report, Brazil - Export Financing Programme for Aircraft, WT/DS46/AB/R, adopted 20 August 1999, paragraph 141. Benitah (2001, p. 186) concludes that an attempt to demonstrate that a subsidy is inconsistent with development needs is rather doomed from the start, because, in practice, there will always be some justification to claim that it is not. 


\subsubsection{Element 1: Specificity}

The element of specificity requires that a subsidy be granted in particular to one enterprise or industry or a group of enterprises or industries. ${ }^{61}$ The SCM Agreement covers both subsidies granted at the national level as well as the sub-national level. The reference group consists of all enterprises and sectors of industry within the jurisdiction of the government authority granting the subsidy. Subsidies granted to all enterprises or to all sectors of industry in such jurisdiction are therefore not regarded to be specific, and thus not to be actionable.

Article 2 of the SCM Agreement provides a number of principles that may be used to determine whether a subsidy is specific: ${ }^{62}$

- Specificity is considered present in case of an explicit limitation of the access to a subsidy or subsidy scheme to certain enterprises;

- it is considered not to be present if the eligibility for a subsidy and the amount of subsidy is based on objective criteria and conditions. Enterprises should be eligible once these criteria and conditions are met and - vice versa - they should not be eligible once they are not met. The criteria and conditions should be printed in an official document in order to enable verification. Criteria and conditions are considered to be objective if they are neutral, when they do not favour certain enterprises or sectors over others, and when they are horizontal in application, in relation to criteria like number of employees or the size of the enterprises.

Notwithstanding the above, there may be other reasons to assume specificity. Other factors may therefore be considered:

- only a limited number of enterprises make actual use of a subsidy programme;

- a subsidy programme is predominantly used by certain enterprises;

- a disproportionately large amount of subsidy is granted to certain enterprises;

- the manner in which discretion has been exercised. The frequency of and reasoning for approval or refusal will be taken into consideration.

If access to a subsidy is limited to certain enterprises within a designated geographical region within the jurisdiction of the granting authority, it will be considered specific.

Regarding the latter, it is of special importance to tax incentives to establish an appropriate reference group in order to determine whether there is any 'limitation'. When there is one tax law on income or corporation taxes applicable to the entire territory of a Member State, the reference group will consist of all the enterprises 
and sectors of industry within that territory. Providing lower tax rates to companies in a specific region, in comparison to an otherwise unitary tax level, could thus lead to specificity. However, in some federal states the competence to levy direct taxes like income tax and corporation tax is not at the federal level. If each state within such federation may levy its own taxes, specificity must be present within the territory of that state. One cannot simply assume specificity - at the federal level on the basis of a difference in taxation between the states. ${ }^{63}$ This is confirmed in the SCM Agreement:

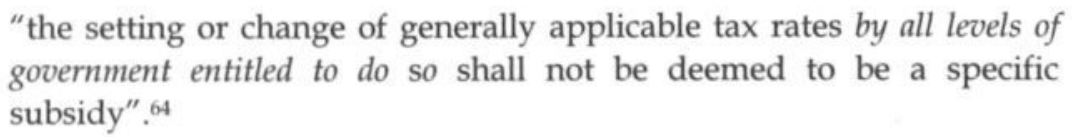

"the setting or change of generally applicable tax rates by all levels of government entitled to do so shall not be deemed to be a specific subsidy". ${ }^{64}$

Even in non-federal Member States there may be so-called independent or autonomous regions that have the authority to take care of (part of) their internal direct taxation. This kind of regional taxation could in essence be covered by the aforementioned text. However, I reckon that the establishment of an administrative region for the mere purpose of regulating regional direct taxation will probably give rise to an exception. If this region has no governmental tasks of its own - like providing education, infrastructure, social security, health care and so on - its establishment might be regarded as an integral part of a specific, regional subsidy scheme ${ }^{65}$ The region's entire tax regime could then qualify as an actionable subsidy.

\subsubsection{Element 2: Adverse Effects}

Apart from specificity, some kind of adverse effect must result from a subsidy as listed in Article 5 of the SCM Agreement. These include:

- injury to the domestic industry of the affected Member;

- nullification or impairment of benefits accruing under GATT 1994; ${ }^{66}$ and

- serious prejudice to the interests of another Member.

See also WESTIN (1997), p. 160.

Article 2.2 SCM Agreement. Emphasis added by the author.

See also chapter II.1.5.8.

These benefits consist of, among other, the elimination of quantitative import restrictions, the abolishment of indirect taxes and duties levied specifically on imported goods and tariff concessions. These benefits aim at improving market access. When subsidisation would effectively undercut such improvement, the benefits agreed upon could be nullified or impaired. This will not be further discussed in relation to direct tax incentives. 


\section{Injury}

Article 15 of the SCM Agreement covers the determination of injury. ${ }^{67}$ The term 'injury' covers material injury to the domestic industry of a WTO Member State and the threat thereof. ${ }^{68}$ Material injury can be present, among other, depending on whether:

- there has been a significant increase in the volume of subsidised imports, either relative or absolute in comparison to the production or consumption in the importing Member's territory;

- there has been significant price undercutting by subsidised imports, in comparison to the price of a similar product of the importing Member;

- subsidised imports significantly depress prices or prevent regular price increases from occurring.

The objective fulfilment of one or more of these factors does not provide a definite answer to the actual presence of material injury. ${ }^{69}$ The consequent impact of these volume or price effects on the domestic producers must also be determined. Relevant economic factors and indices should therefore be considered, like decline in output, market share, productivity and negative effects to growth, cash flow, employment and so on. Of course, a causal relationship between the subsidised imported goods and the factors and indices above must be established. Therefore, one must take other relevant factors into consideration, such as the development of the volume and prices of non-subsidised imports from other countries, changes in demand and consumption, regular competitive behaviour between foreign and domestic competitors, domestic productivity and so on.

As mentioned before, injury also includes the threat of material injury. The potential of causing material injury must therefore also be considered. Such injury must be clearly foreseeable and imminent, based on objective factors like: ${ }^{20}$

See Articles 5 and 15 SCM Agreement in reference to Article VII GATT.

Footnote 45 to the SCM Agreement. There actually is a thind category of injury: material retardation of a domestic industry. It would require the demonstration of a delay in the progress or accomplishment of a domestic industry in a Member State. This kind of injury is hardly called upon in SCM Agreement procedures and will therefore not be discussed.

See also Benitah (2001), p. 14. He points out that the aforementioned list of elements does not provide for a precise technical definition of "injury". Because of the specific instruction in Article 15.2 of the SCM Agreement that none of these elements are necessarily decisive in regard to establishing injury, Benitah concludes that the competent investigating authorities - as for Track II: a panel - are free to determine the relative weight of each of them.

Article 15.7 SCM Agreement. 
- the trade effects that are likely to arise from the nature of the subsidy;

- significant increases in subsidised imports indicating the probability of a substantial increase in imports;

- the exporting capacity of the exporter of subsidised goods, either freely disposable or as a result of an imminent, substantial increase, indicating the probability of increase in subsidised exports; ${ }^{71}$ and/or

- the prices at which imports are entering, when they have a significant depressing or suppressing effect on prices on the domestic market and are likely to increase the demand for further imports.

These and other factors taken together should thus lead to the conclusion that more subsidised exports are imminent and that, unless countervailing duties (to be discussed in paragraph 6 , infra) are imposed as a protective measure, material injury will occur in the very near future. ${ }^{72}$

\section{Serious Prejudice ${ }^{73}$}

Another kind of adverse effect that could lead to the conclusion that a subsidy is actionable, is that it arouses, or threatens to arouse serious prejudice to the interests of another WTO Member State. Serious prejudice may arise if: ${ }^{74}$

- a subsidy has the effect to displace or impede the imports of a like product of another Member into the market of the subsidising member (thus an import restricting effect), ${ }^{75}$ i.e. when exports from A to B are substituted by internal products from $B$;

- a subsidy has the effect to displace or impede the exports of a like product of another Member from a third country market, i.e. when exports from $\mathrm{A}$ to $\mathrm{C}$ are substituted by subsidised exports from B to C. This displacement effect includes changes in the relative market shares at the disadvantage of non-subsidised products that are alike, such as (1) an increase in the market share of the

It should be considered that other export markets might absorb part or all of the additional exports.

Article 15.7 SCM Agreement. Also see a similar interpretation of 'threat' in the Appellate Body Report, United States - Safeguard Measures on Imports of Fresh, Chilled or Frozen Lamb Meat From New Zealand and Australia, WT/DS177AB/R, WT/DS178AB/R, adopted 16 May 2001, paragraphs 125 and 136 , concerning the threat of serious injury in a safeguards case. It should be noted that the term 'serious injury' indicates the use of a much higher standard of injury than the 'material injury' required by the SCM Agreement in conjunction with article VI GATT (ibid., paragraph 124). $\mathrm{A}$ is the complaining Member; $\mathrm{B}$ is the subsidising Member; $\mathrm{C}$ is a non-subsidising third country.

A "like product" is a product that is identical (i.e. alike in all respects) to the product in question, or a product that has characteristics closely resembling those of the product in question. (Footnote 46 to the SCM Agreement.) 
subsidised good, (2) a constant market share for that good though it would have declined without subsidisation, or (3) a decline of such share at a slower rate than it would have without a subsidy;

- a subsidy has the effect to significantly undercut prices by the products from B compared to those from $\mathrm{A}$ in the same market, or to create price depression or suppression or lost sales in the same market (e.g. pricing below cost-level that would put competitors out of business) ${ }^{76}$ or

- a subsidy has the effect to increase B's world market share in a primary product as compared to the average share held in the previous three years, provided that the increase follows a consistent trend over a period when subsidies have been granted (i.e. the increase occurred as from the date of granting the subsidy or thereafter during the granting period).

If part of the adverse effect is caused by circumstances attributable to the complaining Member, for instance by restricting exports and/or imports by the Member States itself, natural disasters and strikes at home affecting export, or a voluntary reallocation of exports to other markets by the industry itself, displacement or impediment will not be present. ${ }^{77}$

A Member State that proceeds against an actionable subsidy should normally demonstrate that an adverse effect like serious prejudice is present; this demands an intensive analysis of the facts. However, back in 1995 when the SCM Agreement came into force Article 6.1 of that Agreement provided that serious prejudice would be deemed present if certain criteria had been fulfilled. This Article has expired as of 31 December 1999 because no agreement could be reached on extending its application. ${ }^{78}$ Nevertheless, these criteria are mentioned below in order to provide an indication of what has been considered to provide evidence for the presence of serious prejudice. The criteria were:

- total ad valorem subsidisation of a product exceeds 5 percent; ${ }^{79}$

- subsidies are granted to cover operating losses sustained by an industry;

Price suppression means the inability of competitors to raise prices according to market conditions (adjustment to inflation a cost increases) due to subsidised competition. Price depression means the necessity to reduce prices in order to compete with the subsidised competition, even below the normal level of costs.

Article 31 SCM Agreement.

This percentage had to be calculated in terms of the cost to the government granting the subsidy divided by the value of the recipient's total sales in the 12 months prior to subsidisation, if necessary indexed by the rate of inflation. In a start-up year the $5 \%$ limit would have been replaced by a maximum rate of $15 \%$ of the total funds invested in the starting firm. (See Annex IV to the SCM Agreement concerning the now ineffective Article 6.1(a).) 
- subsidies are granted to cover operating losses sustained by an enterprise, with the exception of a subsidy given merely to provide sufficient time for the development of long-term solutions and to avoid acute social problems (like discharges en masse), provided that it is a non-recurrent, one-time measure that cannot be repeated for that enterprise;

- government-held (tax) debt is forgiven; or

- subsidies are granted to cover repayment of government-held debts.

When one of the aforementioned conditions had been fulfilled it would have been the task of the granting Member State to demonstrate that serious prejudice has not arisen. It could have done so by demonstrating that the subsidy at issue did not result in one or more of the four effects mentioned in the beginning of this paragraph. ${ }^{80}$

\subsubsection{Actionable Subsidy Procedure}

Article 7 of the SCM Agreement provides some specifics for actionable subsidy procedures. Again, the DSU provides the general framework for this kind of dispute settlement procedure. The actionable subsidy procedure will now be outlined.

If a WTO Member has reasons to believe that a subsidy results in adverse effects, it may request consultations with the granting Member and state the available evidence in regard to (a) the existence and nature of the subsidy, and (b) the adverse effects caused. Should both parties not agree upon a solution within 60 days, any party may refer the matter to the DSB and request the establishment of a panel. The panel will be composed and its terms of reference will be set within 15 days from establishment. Within 120 days, the panel must provide its final report. This report will be adopted by the DSB within 30 days of its distribution, unless it is appealed within that period of time. ${ }^{81}$ If the report is appealed, the Appellate Body should provide its decision within 60 days, extendable to 90 days. The DSB should then adopt the Appellate Body report (together with the panel report) within 20 days of its distribution. Parties may mutually agree to extend these time limits. ${ }^{82}$

If the presence of an actionable subsidy has been determined by adoption of a panel or Appellate Body report stating so, the defending Member must either remove the adverse effects or withdraw the subsidy. Should it not have done so within 6 months after adoption of the report(s) - which is up to a 21.5 panel to determine within 90 days $^{83}$ - the DSB will grant authorisation to the complaining

Article 6.2 SCM Agreement.

The DSB may decide by consensus not to adopt the report. This is rather unlikely, because the DSB is made up of representatives of all WTO Member States. Consensus would therefore require both parties to the dispute to agree including the 'winning' party.

Footnote 20 to the SCM Agreement.

See paragraph 3.2 .3 , supra. 
Member to take countermeasures in the absence of an agreement between parties on compensation. ${ }^{84}$ These measures must commensurate with the degree and nature of the adverse effects; a request for arbitration is possible. ${ }^{85}$

Until 31 December 1999 a subsidy that was not specific, would have been classified as non-actionable. I.e. the aforementioned procedure would not have applied to such subsidies. This explicit exclusion no longer applies. ${ }^{86}$ However, a subsidy shall only be subject to the provisions on actionable subsidies if it is specific. $^{87}$

\section{Track II: Withdrawal of Subsidies}

\subsection{The Need to Withdraw}

To what extent may a WTO Member choose to uphold a tax incentive and/or its adverse effects once a panel determines that it is prohibited or actionable and recommends withdrawal or undoing the adverse effects. May such Member keep the incentive and take countermeasures for granted? This is a matter of principle. The objective of the first part of the SCM Agreement (the prohibited / actionable subsidy procedure) is to get rid of certain subsidies when necessary. As JACKSON recalls the WTO understanding on rules and procedures governing the settlement of disputes ('DSU') establishes a clear preference to perform the withdrawal. ${ }^{88}$ Its primary objective is to secure the withdrawal of measures that are inconsistent with one of the WTO Agreements. Compensation and the suspension of concessions should only be resorted to if immediate withdrawal is impracticable; they are only meant to be a temporary measure pending the withdrawal. ${ }^{89}$ The DSB is to keep the matter under surveillance until the recommendations are properly implemented. As COTTIER argues, the mere threat of the use of countermeasures will be an incentive to abide by the panel's ruling. As a result of the reporting and monitoring systems,

The DSB may decide by consensus not to do so. Compensation refers to lowering tariffs on imported products from the affected Member State and alike, not to monetary compensation. See the former Article 8.1(a) SCM Agreement and paragraph 3.1, supra.

Article 1.2 SCM Agreement. It is perhaps unnecessary to say that there can be no recommendation to remove adverse effects of a non-specific subsidy or to withdraw it whatsoever. Apart from the direct exclusion contained in Article 1.2 SCM Agreement it should also be considered that such recommendation would require a panel to determine that a subsidy actually resulted in adverse effects to the interests of another WTO Member within the meaning of Article 5 SCM Agreement. The latter also requires that such effects are caused by a specific subsidy, referring to Article 1.2 SCM Agreement. (See Article 7.8 SCM Agreement.) 
Members are under a pressure because they are called to justify delays and difficulties to comply with their WTO obligations. ${ }^{90}$

\subsection{Repayment of Subsidies}

In order to determine the scope of a recommendation to 'withdraw a subsidy' one must determine whether such withdrawal only aims at the future or whether it may also have an effect on the past. At only one occasion the issue of 'recovery' was placed in a WTO context.

In the case of subsidies provided by Australia to producers and exporters of automotive leather, a panel recommended the withdrawal of a prohibited exportrelated grant from a certain beneficiary within 90 days. ${ }^{91}$ In response this beneficiary repaid part of the grant. At the same time, Australia provided that beneficiary with a loan on non-commercial terms. This seemed to be a reimbursement in the view of the US. The US argued that the portion of the grant that is to be withdrawn, is the portion of the funds provided that continues to confer a benefit to the beneficiary as from the date the panel report was adopted. ${ }^{92}$ It calculated this "prospective portion" by allocating the amount awarded over the useful life of the beneficiary's production assets. Interest was added to this calculation. Australia argued that since the grant payments were tied to sales performance targets, the amount repayable is the amount allocable to export sales as from the date the panel report was adopted until the date on which the performance target under the grant contract ended. Thereby the part of the grant allocated to non-export sales has been excluded from repayment. Even though Australia maintains that repayment is not necessary in order to 'withdraw' a subsidy, any payment can only be of a prospective nature, thus from the date of adoption of the panel report.

In order to settle this matter a 21.5 procedure was started in order to determine whether the recommendation to withdraw had been complied with. ${ }^{93}$ The US and Australia both agreed that repayment (if any) is to be considered a prospective remedy. The 21.5 panel however did not agree that repayment is to be a mere prospective remedy:

"where any repayment of any amount of a past subsidy is required or made, this by its very nature is not a purely prospective remedy. No theoretical construct allocating the subsidy over time can alter this fact. In our view, if the term 'withdraw the subsidy' can properly be

COTTIER (1998), p. 340.

Panel Report, Australia - Subsidies provided to Producers and Exporters of Automotive Leather, WT/DS126/R, adopted 16 June 1999, paragraph 10.7. The panel considered 90 days to be the maximum period appropriate as it is required that export subsidies are to be withdrawn "without delay".

Panel Report, Australia - Subsidies provided to Producers and Exporters of Automotive Leather (Recourse to Article 21.5 of the DSU by the United States), WT/DS126/RW, adopted 11 February 2000, paragraph 6.9. See paragraph 3.2 .3 , supra. 
understood to encompass repayment of any portion of a prohibited subsidy, 'retroactive effect' exists." ${ }^{94}$

Since the Appellate Body repeatedly observed that panels are to apply the general rules of treaty interpretation set out in the Vienna Convention on the Law of Treaties, the panel abides thereby. The panel considers that - based on the fundamental principle of effet utile - a treaty interpreter is not free to adopt a meaning of the term "withdrawal" that would reduce part of SCM Agreement to redundancy or inutility. ${ }^{95}$ The panel then finds that in a straightforward reading of the text, the ordinary, textual meaning of "withdraw the subsidy" may encompass the taking away or removal of a prohibited subsidy.

The panel considered that the SCM Agreement provides that Members may neither grant nor maintain a prohibited subsidy. ${ }^{96}$ It then expressed that when the withdrawal of a subsidy would not encompass repayment it would give rise to serious questions regarding the efficiency of this remedy in cases involving nonrecurring subsidies paid in the past that are not contingent upon future export performance. Part of the subsidy would be beyond the reach of a recommendation to withdraw, no matter how clear the violation of the SCM Agreement prohibition on export-related subsidies may be. ${ }^{97} \mathrm{~A}$ recommendation to "withdraw a subsidy" can only effectuate that prohibition if it is effective regardless of the form in which the subsidy is found to exist..$^{98}$ The panel thus expresses that it does not believe that the strict prohibition on export subsidies was meant to have been established only to be undermined by a remedy which is ineffective in case of such subsidies. ${ }^{99}$

The panel therefore concludes that a recommendation to withdraw is not limited to prospective action and that it thus may encompass the repayment of a prohibited subsidy. ${ }^{100}$ In respect to Australia's one-time subsidy at issue, it found

"no basis for concluding that anything less than full repayment would suffice to satisfy the requirement 'to withdraw the subsidy' in a case where repayment is necessary." 101 to Article 21.5 of the DSU by the United States), WT/DS126/RW, adopted 11 February 2000, paragraph 6.22 . 
As for the payment of interest, the panel did not understand the obligation to withdraw to have the intention to fully restore the status quo. It considered that:

\begin{abstract}
"[a] requirement of interest would go beyond the requirement of repayment encompassed by the term 'withdraw the subsidy' and is therefore, we believe, beyond any reasonable understanding of that term." 102
\end{abstract}

Since the Australian loan was conditioned upon repayment of the previous export subsidy, the panel concluded that Australia failed to effectively withdraw its original prohibited export subsidy on time. ${ }^{103}$

The panel did not rule that repayment is the only method of withdrawal. However, it considered that it was the proper method in regard to one-time exportcontingent subsidies granted in the past. It would have been possible to withdraw the prohibited export subsidy by lifting the export contingency off of the Australian grant by not demanding that export performance targets are met. However, as the panel considered, this cannot change the fact that a close tie between anticipated exportation and the grant of the one-time subsidy existed at the time it was provided. The export encouraging effect in the past cannot be compensated by this kind of withdrawal, at least not in this case. Therefore retroactive repayment was necessary in the panel's view.

The US and Australia had agreed in advance not to appeal the panel report, so the Appellate Body did not get round to reviewing the matter. The report has subsequently been adopted by the DSB. ${ }^{104}$ In the DSB meeting the US admitted that the panel's remedy went beyond that sought by it. Australia remarked that it was forced to relinquish its appeal rights in fear of retaliatory measures by the US. Be that as it may, I cannot but wonder whether the risk of an Appellate Body confirming the panel's view on the issue of retroactive payment would have kept either party from appealing in the absence of the agreement, taking regard of the US and Australian responses to the panel report in the DSB.

In an appeal to the DSB not to adopt the report, Australia argued that the retrospective remedy was if a punitive nature which would have significant systematic implications for the dispute settlement system. There was no statute on limitations since retrospectivity would be a new and risky path for the WTO to go. ${ }^{105}$ There was no legal basis in WTO law for punishing private companies by repayment. In a DSB meeting the Canadian representative said that retroactivity was not only contrary to GATT/WTO custom and practice, but it would also violate

Ibid., paragraph 6.49 .

103 Ibid., paragraphs 6.50 and 6.51

104 Minutes of Meeting, Dispute Settlement Body, WT/DSB/M/75, circulated 7 March 2000.

105 Retroactive repayment is distinct from retrospective repayment. In case of the first a certain activity has ended or a certain action has been taken that was targeted by the repayable tax incentive. Thé latter refers to ongoing activities that started in the past and that have not finished yet. 
the Vienna Convention. Retroactivity should only be interfered when it is clearly indicated by the text of the treaty. In urging other DSB Member expressing their dissatisfaction, Canada hoped that the panel report would be not having precedential value. Representatives of Brazil, Japan and Malaysia concurred. However, the representative of Hong Kong, China appreciated the report. He argued that effective remedies represented a cost to Members and could therefore secure the observance of the WTO Agreements. ${ }^{106}$

Apart from the adopted 21.5 panel report only being binding between parties, the fact that an Appellate Body review is missing and the fact that the parties involved opposed to the panel's view on retroactivity do wonder whether the panel's reasoning will be followed again in future dispute settlement procedures. This is anything but certain. Nevertheless, I fully agree with the panel's reasoning when it considers that a prohibition of a one-time subsidy can only be remedied effectively by retroactive action. Without this possibility, there could never be an effective procedure against a one-time subsidy since by the time a panel would submit its recommendations there would be nothing to withdraw (for the future) at all. Such procedure would then only serve to give an indication to the WTO Member involved how it may better comply with the SCM Agreement in the future.

In my opinion, retroactive repayment should not only be considered in regard to one-time-only subsidies but also in regard to recurring subsidies. Otherwise, it would be possible to periodically grant prohibited subsidies until such time a panel decides - if and when established - that they are to be withdrawn. From an economic point of view, I do not see why the concept of 'withdrawal' should include recovery in regard to one-time subsidies but not in regard to payments of recurring subsidies that have already been made. The economic effects of both are comparable. From a legal point of view, I consider it hardly plausible that the term 'withdrawal' is meant to have a different meaning depending on the kind of subsidy at hand. Even though it could be considered that effective 'withdrawal' of recurring subsidies would mean nothing more than putting a stop on future payments, I do not rule out that 'withdrawal' will actually be considered to include the restitution of past payments. This will be up to future panels and the Appellate Body to settle. ${ }^{107}$

That being said, one must keep in mind that repayment of prohibited subsidies is still an undiscovered area in the context of international trade law and that it is far from becoming an accepted part of WTO remedy procedure. Should future panel or Appellate Body reports affirm the existence of a duty to repay, then this would lead to a landmark shift in the dispute settlement practice of the WTO. ${ }^{108}$

As for the US and Australia, they reached a mutually satisfactory solution to end their dispute (Notification of Mutually Agreed Solution, WT/DS126/11, circulated 31 July 2000). round negotiations.

108 Since there only is a preliminary indication that there is an obligation to repay prohibited subsidies, provisions on the implementation of such obligation are lacking of course. There is only the certainty that 
To my mind, withdrawal of the face value of a prohibited export subsidy would be insufficient to effectively undo the breach of a prohibition on the use of export-contingent subsidies (or import-substituting subsidies for that matter). Should the panel's assessment be correct as to the lack of an implicit basis to require the payment of interest, I recommend that such basis be provided for if and when it is decided that 'withdrawal' is to include repayment.

\section{Track II: Aspects of Prohibited Fiscal Subsidies}

\subsection{The DISC}

In the following paragraphs I will discuss the most important fiscal subsidy case as far as direct taxation is concerned - in WTO dispute settlement proceedings to date; the Foreign Sales Corporation ("FSC") case. As we will see the main issue will be whether replacing or altering a certain tax regime suffices in order for a subsidy to be effectively withdrawn. Some tax-specific aspects of prohibited export and import substituting subsidies will also be discussed. Before introducing the FSC case it is important to go back to the pre-1995 GATT Subsidy discipline in order to get some background information on the dispute between the EC and the US on fiscal export subsidisation. The focus will be on the most important material determinations made in regard to fiscal export subsidisation; pre-1995 Subsidy procedure will not be addressed.

This paragraph will look into the US Domestic International Sales Corporation (DISC) tax regime, which was introduced to promote export activities from the US back in 1972.

In order to qualify as a DISC a company must among other be an incorporated under the laws of a US State. More important, each taxable year its gross receipts must be derived from export activities (e.g. sale, exchange, lease or rental of export property outside the US) for at least $95 \%$ and its assets should be export related (e.g. export property and assets used for export sales, leases and services) for, again, at least $95 \%$.

The original DISC scheme provided that half of the income attributed to a DISC was deemed to have been distributed. It would then be taxed at the shareholder's level. The tax on the other half of the DISC income would be deferred until its distribution or termination of the DISC status. This income should either have been reinvested in certain export assets or provided as a (limited) loan to domestic manufacturers (often related to the DISC, such as a parent or supplier). The income attributed to the DISC was not determined at arm's length 
but by special inter-company pricing rules. On the basis thereof, a substantial part of the total export profit could be attributed to the DISC. 109 Effectively, about $25 \%$ of the tax on total export profits (parent and DISC) would be - almost permanently - deferred.

The EC (supported by Canada) challenged the DISC regime under the rules of Article XVI:4 of the old GATT 1947, the old subsidies provision. This Article obliged Member States not to grant subsidies on the export of (non-primary) products which would result in the sale of such goods for export at a price lower than the comparable price charged to domestic buyers. Unlike the SCM Agreement, export subsidies were not prohibited as such. Their negative effect on price setting had first to be established.

In response, the US challenged tax regimes of France, Belgium and the Netherlands. Four panels were established formally, even though their composition was alike. For this reason I will refer to these panels as 'the panel'. ${ }^{110}$

In 1976 the panel gave its ruling. ${ }^{111}$ A DISC was entitled to defer the taxation of its profits without a proper interest charge. There was also a tax deduction for export promotion expenses incurred in shipping and air transportation, provided that such transportation was of US origin. The DISC legislation was therefore inconsistent with Article XVI:4 of the GATT 1947. The panel report was adopted by the DSB in 1981.112

One of the motives for the DISC regime seemed to be that the US sought a possibility to prevent a setback for their exporters. European countries were

The above description of the original DISC regime has been based upon Gilles Sion (1980), pp. 178-181. Also see $\$ 992$ and $\S 993$ of the Internal Revenue Code, version of 1970 . The income qualifying for DISC treatment was the greater of (1) $4 \%$ of export sales receipts, or (2) $50 \%$ of combined taxable income of the DISC and its related suppliers (often the parent), or (3) normal DISC taxable income on an arm's length basis.

110 For an historical overview of the difficulty of establishing the panel, which took over two and a half years for both parties to agree, see JACKsON (1978), pp. 760-764. It is interesting to see that outside tax experts were made part of the panel on request of the US, even though both experts where European professors. It was the EC that requested separate panels but the US managed to agree upon panels composed of the same individuals.

111 GATT Panel Report L/4422 of 2 November 1976.

112 Under GATT 1947, panel reports could only be adopted when parties agreed. No separate procedure for appeal was available at that time. The US needed time to alter its legislation, admitting that its DISC regime was not in compliance with GATT in 1979, and therefore urged the EEC not to pursue the matter any further until 1981. (See Tax Notes, 2 August 1982.) This explains the delay in adoption by the GATT Council, together with the need of all parties involved to create some kind of statement all parties could relate to (the 1981 understanding addressed in paragraph 3.1.1). The US Trade Representative renounced the 1979 statement from the US Treasury in 1982. 
applying a system of indirect taxes (especially VAT); these taxes may be adjusted at the border upon export without falling within the subsidy prohibition. ${ }^{113}$ On the other hand, the SCM Agreement does not allow the adjustment of direct taxes at the border when products are exported; it regards this kind of adjustment to be a prohibited export subsidy. In the US indirect taxes only play a minor part in comparison to direct taxes. Since it not allowed adjusting direct taxes at the border some alternative relief was pursued. HUFBAUER and GABYZON argued that by a change in GATT rules, the border adjustment of certain direct contributions, like wage taxes and social security premiums should be allowed in order to compensate for predominant direct taxation. ${ }^{114}$ On the other hand, WESTIN and VASEK argue that as long as rebating indirect taxes at the border is taken for granted under the SCM Agreement - whatever may be of the economic reasoning for such exclusion - the US should at least try to experiment with a system of VAT. ${ }^{115}$

The US argued that it had introduced DISC legislation to counter distortions created by tax practices of among other the EC Members. The panel quite rightly concluded that the US should have had recourse to the remedies provided by the GATT. It also remarked that the fact that even though tax practices are used for a period of time in a number of countries without other GATT Members complaining, this was not in itself conclusive evidence for consensus on their compatibility with the GATT.

In regard to the Belgian, French and Dutch tax systems, the panel concluded that these countries allowed "some part of export activities belonging to an economic process originating in the country" to be outside the scope of their respective tax system as a result of the application of the territoriality principle (France, Belgium) or the world-wide principle in combination with a qualified exemption for foreign income, i.e. the exemption of an enterprise's profit as far as it was carried on through a permanent establishment or representative outside national territory (the Netherlands). ${ }^{116}$ This created the possibility for a benefit to exports when "income and corporation tax provisions were significantly more liberal in foreign countries" because this benefit was not available to domestic activities. An illustration of what the panel implied will follow:

Country A uses a territorial tax system, taxing only profits that arise from activities within its territory. A product is now made and sold within country A. The profit made amounts to 100 . Taxed at a $40 \%$

For an overview of the GATT background and case law on border tax adjustments of indirect taxes, see DEMARET / STEWARDSON (1994) as well as WESTIN (1997). WESTIN and VASEK (2001) have reservations in respect to allowing VAT to be rebated, because a destination type VAT which allows for levying VAT on import and rebating it on export does have a certain effect on international trade as would the rebating of direct taxes at the border. They propose a WTO Working Party to take a look at this issue. Hufbauer / Gabyzon (1996), p. 56. 
rate this would lead to a tax of 40 . Now suppose the process took place in part in country B (for instance, sales office in B, manufacturing in A). B uses a similar tax regime but for a tax rate of $30 \%$. Suppose half of the profit can be attributed to the actual sale in B and half to manufacturing activities in A. B would now tax 50 at $30 \%$ and A would $\operatorname{tax} 50$ at $40 \%$. Total taxes would thus be 35 . The difference in tax of 5 would have to be considered a benefit conferred by $\mathrm{A}$.

Although the panel admitted that this is the incidental consequence of the taxation principles chosen, rather than a policy intention to stimulate export, it concluded that the above constituted an export subsidy. It considered that there was a partial tax exemption "[in] circumstances where different tax treatment in different countries resulted in a smaller total tax bill in aggregate being paid on exports than on sales in the home market". The panel added that this benefit could increase if the principle of at arm's length transfer pricing was not fully observed, because of exceptions to this principle, flexibility in the administration of transfer pricing rules or the absence of a specific 'at arm's length' requirement.

It will be rather obvious that these panel reports endangered the principle of territorial taxation as one of the generally accepted fiscal systems. In my opinion the DISC panel(s) came to the erroneous conclusion that the choice to use a territorial tax regime led to a subsidy. It is rather obvious that not taxing income that is not subjected to tax under the normative regime cannot be considered a benefit. It is the logical consequence of a country adopting a territorial regime to leave it up to other countries to decide if and how they tax profit attributable to activities taking place within their territories, even in regard to activities carried out by enterprises resident in the first mentioned country. This is one of the reasons why the GATT Council adopted all four reports in 1981 on the understanding that economic processes located outside the territory of the exporting Member need not to be subjected to tax by that Member. Its chairman added that this did not preclude Members from taxing the profits on transactions outside their territory; they are only not required to do so. ${ }^{117}$ Furthermore, it was understood that arms-length pricing should be observed. None of the parties involved objected to these conclusions. ${ }^{118}$

It followed from the 1976 DISC panel reports - read in light of the 1981 Understanding - that a full exemption of export-related profits would violate GATT 1947 Subsidy provisions. The exporting state was not allowed to exempt that part of export-related profits that could be attributed to activities within its territory. Whether this still applies to the new WTO Subsidies regime is to be discussed hereafter. ${ }^{119}$

118 The '1981 Understanding', Journal of World Trade Law, 1982, p. 362. Fischer-Zernin (1989, p. 237) pointed out that the Council's statement arguably even restricts the panel's ruling. 


\subsection{The FSC Regime}

\subsubsection{Introduction}

The DISC regime was succeeded by the FSC regime.

An FSC is a 'foreign-based' subsidiary of one or more US based corporations. ${ }^{120}$ In regard to being foreign-based, it is required to hold the meetings of shareholders and directors outside the US as well as the principal bank account used for most salary, fee and dividend payments. In addition at least one office must be outside the US and the economic processes should take place outside the US. The latter requires that the FSC participates outside the US in the sales process and that a major part of the direct costs of transactions are incurred by the FSC. These and other provisions do not ensure that there actually is substantial foreign activity at all, especially since the US Administration is very lenient in allowing several workarounds. ${ }^{121}$

The FSC's main activity must be the export of goods from US origin; i.e. these goods must be manufactured within the US and at least $50 \%$ of its content must come from the US. Up to two-thirds of the tax on the FSC's qualifying income (i.e. income from foreign trade of services and goods from US origin) is exempt from US corporate income tax. ${ }^{122}$ This part of the income may then be distributed to the US parent back in the US subject to a full deduction at the parent level, so that it is neither taxed there. Special transfer pricing rules made sure that a substantial amount of income was attributed to the FSC.

An FSC should have no more than 25 shareholders nor have preferred stock and it should neither be part of a controlled group of corporations that includes a DISC. Also, at least one of its directors must not be an US resident.

Regulations did allow telephone meeting to qualify if the persons exercising the majority of the voting power are located outside the US. Also it was explicitly provided that the bank account may be at a foreign branch of a US bank. Instructions in regard to bank account were allowed to originate in the US. The sales test would be met when either the solicitation (such as sending a brochure to a specific, targeted customer), the negotiation or the making of the contract takes place outside the US. The direct costs test could have been met by taking the price of contracts into account of an activity performed on behalf of the FSC by a contractor. The latter may carry out its activities from within the US. See 26 CFR \$1.924 (1997 edition). 
It is interesting to see that the replacement of the DISC regime by the more stringent FSC regime led to a reduction of US manufacturing exports of $3.1 \% .{ }^{123}$ But since the EC was still convinced that export subsidisation as such was not over yet, it challenged several aspects of the FSC regime be it after letting 14 years pass. Parts of the panel and Appellate Body reports in regard to the EC's complaint will now be brought within the fiscal spotlight. An interesting fact is that the mere filing of the complaint itself resulted in a $0.5 \%$ drop in the share price of the average affected exporter on the same day. ${ }^{124}$

\subsubsection{The Territoriality Principle}

The FSC regime was more or less based on the assumption that it was up to the US to decide whether or not to tax income out of foreign processes. As addressed before, the GATT Council considered back in 1981 that economic processes located outside the territory of a Member do not need to be taxed necessarily, even if such process include export transactions. Members are not precluded from taxing the profits on transactions outside their territory; they are only not required to do so. ${ }^{125}$ The FSC panel decided that this 1981 understanding cannot provided guidance in understanding detailed provisions of the SCM Agreement, since that agreement did not exist at the time the understanding was adopted. ${ }^{126}$ The Appellate Body points out that the SCM Agreement contains a broader subsidy discipline than the GATT 1947. Therefore the 1981 Understanding, relating to the interpretation of Article XVI:4 of the GATT 1947 (the old 'subsidies' provision), cannot provide guidance in determining whether a measure is an export subsidy under the 1994 SCM Agreement. 127

Notwithstanding the fact that the 1981 Understanding was not able to provide further guidance, the FSC panel came to a somewhat similar outcome regarding the issue of territorial taxation. It ruled that

Going Too Far in Support of Trade, The Economist, 16 December 2000, in reference to DESAI / HINES (2000).

Ibid.

See paragraph IV.6.2, supra, and GATT, Analytical Index: Guide to GATT Law and Practice, 6th edition (1995), volume 1, p. 460.

Panel Report, United States - Tax Treatment For "Foreign Sales Corporations", WT/DS108/R, adopted as modified by WT/DS108/AB/R, 20 March 2000, paragraph 7.85; Appellate Body Report, United States Tax Treatment For "Foreign Sales Corporations" WT/DS108/AB/R, adopted 20 March 2000, paragraph 114.

Appellate Body Report, United States - Tax Treatment For "Foreign Sales Corporations" WT/DS108/AB/R, adopted 20 March 2000, paragraph 117. The Appellate Body also repeats the explicit 1981 statement of the GATT Council's Chairman that the understanding did not affect the so-called Tokyo Subsidies Code, the SCM Agreement's predecessor (ibid., paragraph 118). 
"the United States is free to maintain a world wide tax system, a territorial tax system, or any other type of system it sees fit. This is not the business of the WTO. What it is not free to do is to establish a regime of direct taxation, provide an exemption from direct taxes specifically related to exports, and then claim that it is entitled to provide such an export subsidy because it is necessary to eliminate a disadvantage to exporters created by the US tax system itself." 128

The FSC panel's ruling is supported by tax expenditure theory. Adopting a territorial tax base instead of a world-wide base for application of corporate or entrepreneurial tax does not result in tax expenditure, but any selective deviation from the general jurisdictional principle adhered to - in this case world-wide taxation - will. ${ }^{129}$ The Appellate Body emphasised that the FSC ruling is not on the merits of world-wide or territorial tax systems. However, in choosing between these systems a WTO Member must apply the chosen system in conformity with its WTO obligations. ${ }^{130}$

The US argued that its FSC legislation (i.e. the application of a limited territoriality principle) aimed to avoid double taxation. The panel rejected this argument, not only because the US already applied foreign tax credits on a unilateral basis and had concluded treaties on double taxation, but also because two-thirds of the FSC's were established in the Virgin Islands where no income tax was due. ${ }^{131}$

In the FSC panel procedure the EC also claimed that the FSC regime contained a prohibited subsidy contingent upon the use of domestic over imported goods. For reasons of judicial economy the panel did not considered it necessary to make findings with respect to this claim. ${ }^{132}$

The outcome of procedure was that the FSC regime contained a prohibited export subsidy and was therefore to be withdrawn. Since the adoption of the October 1999 FSC panel report by the DSB was likely to take place no sooner than spring of 2000, the panel specified that the FSC subsidy was to be withdrawn with

Panel Report, United States - Tax Treatment For "Foreign Sales Corporations", WT/DS108/R, as modified by WT/DS108/AB/R, 20 March 2000, paragraph 7.122.

See MCDANIEL/SURREY (1985), p. 59.

Appellate Body Report, United States - Tax Treatment For "Foreign Sales Corporations" WT/DS108/AB/R, adopted 20 March 2000, paragraph 179. For the record, even if the 1981 Understanding would have been capable of providing some guidance it is not being said that this would have sufficed to keep the FSC regime out of trouble, because of the selective application of its territorial regime. 
effect from the fiscal year 2001, which commenced on 1 October 2000, taking account of the legislative action required. This decision on the implementation period is of special interest. As we have seen in paragraph 3.2.3, supra, panels commonly specify a period of about 90 days for implementation of the recommendation to withdraw prohibited subsidies. ${ }^{133}$

\title{
5.2.3. Alternative Tax Fora
}

The US argued that the EC's complaint in regard to the special transfer pricing rules was inadmissible, since such concerns should be raised in an appropriate specialised tax forum in the first instance. The EC used the OECD guidelines on transfer pricing in its support. The US argued that neither the OECD Transfer Pricing Guidelines nor the US law could govern the dispute on the issue of 'at arm's length'. If the panel would declare the OECD Guidelines to be the appropriate benchmark for measuring compliance, it would impose the norms on over 100 WTO Members that not acceded to those Guidelines. This would therefore go beyond the panel's authority. Furthermore, the US referred to the fact that the 1995 OECD Guidelines did not exist when the SCM Agreement entered into force. This issue has not been addressed in-depth by the panel, since it found that the FSC Scheme had to be withdrawn as such. For reasons of judicial economy, the panel did not regard it necessary to address the special transfer pricing rules since they are part of the FSC Scheme and dependent on the existence of the (prohibited) FSC exemption. ${ }^{134}$

In the course of the proceedings, the US referred to footnote 59 to the SCM Agreement that states:

\begin{abstract}
"Any Member may draw the attention of another Member to administrative or other practices which may contravene with [the at arm's length transfer pricing] principle and which result in a significant saving of direct taxes in export transactions. In such circumstances the Members shall normally attempt to resolve their differences using the facilities of existing bilateral tax treaties or other specific international mechanisms, without prejudice to the rights and obligations of Members under GATT 1994, including the right of consultation [...]."
\end{abstract}

One cannot deny that the US was correct when it stated that the details of the FSC case were very complex and that the implications of any final panel decision on the merits may have on the varied tax systems of the WTO Members could be very farreaching. ${ }^{135}$ The US persists in its claim that until preferred alternatives (like nonWTO tax fora) are exhausted, WTO dispute settlement should be avoided. The EC 
argued that the present dispute was about a prohibited export subsidy and that it was not a tax dispute. Furthermore, the availability of alternative fora does not to prejudice to WTO dispute settlement in the view of the Commission. ${ }^{136}$ The EC also points out that alternative fora like the OECD do not offer a legal basis for the matter to be raised and resolved; the opportunity to discuss the matter cannot be regarded as a mechanism for resolving differences. ${ }^{137}$ The panel ruled that the footnote does not intend to restrict the ability of a WTO Member to resort to WTO dispute settlement. ${ }^{138}$ The Appellate Body notes that the issue of the 'appropriate tax forum' solely relates to the EC's claim in regard to the special transfer pricing rules, since the US did not argue that the EC should have raised its other claims in another forum. ${ }^{139}$

\subsubsection{The FSC Replacement Act}

On request of the US the October 2000 deadline to withdraw the FSC regime was extended to November 1st, 2000. On 15 November 2000, the US repealed the FSC regime effective 30 September 2000. This was done in the "FSC Repeal and Extraterritorial Income Exclusion Act of 2000". ${ }^{140}$ However, transitional provisions do apply. An existing FSC may still use the FSC regime until 2002. In case a binding contract between the FSC (or a related person) and any unrelated person exists on 30 September 2000 the FSC facility will remain to be applicable even for an unlimited time thereafter depending on the duration of such contract.

As a 'WTO-proof' alternative for the FSC regime 'extraterritorial income' was to be excluded from gross income as of 1 October 2000 but for 'extraterritorial income' that is not 'qualifying foreign trade income'. These and other terms will de described roughly hereafter.

Extraterritorial income is the gross income of a taxpayer attributable to foreign trading gross receipts. These receipts can be generated by means of the sale or lease of 'qualifying foreign trade property' that is not destined to be ultimately used inside the US.

Foreign trade property qualifies in case such property is held primarily for sale, rental or lease for direct use, consumption or disposition outside the US in the ordinary course of the trade or by tax treaties "do not provide a basis for one country to object to the tax practices of another when there is no issue of double taxation or loss of tax revenue for that country".

Ibid., paragraphs 7.19-721.

Appellate Body Report, United States - Tax Treatment For "Foreign Sales Corporations" WT/DS108/AB/R, adopted 20 March 2000, paragraph 171. 
business of the tax payer, including receipts from related services. ${ }^{141}$ Furthermore, no more than 50 percent of the fair market value of such property may be attributable to materials used in the production that are manufactured or produced outside the US or the direct costs of labour performed outside the US. Thus at least $50 \%$ of the fair market value of property should be of US origin. ${ }^{142}$

Qualifying foreign trade income is the amount of gross income which - if excluded from gross income - will result in a reduction of taxable income from any transaction of either $30 \%$ of foreign sale and leasing income, $1.2 \%$ of foreign trading gross receipts or $15 \%$ of foreign trade income from such transaction.

The taxpayer (or any contractor acting on his behalf) should participate in the solicitation, the negotiation or the making of the contract outside the US. Moreover, the cost attributable to activities abroad like advertising, sales promotion, processing orders, arranging delivery, invoicing/collecting or delivery related transportation should exceed $50 \%$ of the total direct cost attributable to the sale or lease transaction. ${ }^{143}$ This is the so-called foreign economic process requirement.

It thus follows that income from foreign trade transactions with qualifying property is excluded from gross income if certain substance requirements are met, but only to the extent necessary to produce a certain maximum level of tax advantage. ${ }^{144}$

In a report of the US House Committee of Ways and Means it is stated that the new law modifies the extent to which the US seeks to tax extraterritorial income. It creates a new normative benchmark for taxing such income (i.e. the exclusion from gross income). The Committee emphasised that taxing certain forms of extraterritorial income is an exception to the new general rule of not taxing extraterritorial income. ${ }^{145}$ An U.S. Treasury official stated that no subsidy is created, because there is no right to tax extraterritorial income in the first place. ${ }^{146}$ I would like to refer back to the issue of negative aids discussed in chapter II. If one compares the ultimate effect of excluding a certain category of business income from normal taxation versus excluding 'all' categories of business income except for

Services in regard to engineering and architecture for constructions outside the US do also qualify, as well as the performance of certain managerial services (26 USC \$1.942).

Oil, gas and unprocessed softwood timber cannot qualify (26 USC \$1.943(a)).

If the foreign direct cost of two of the categories of activities mentioned exceed $85 \%$ of the total direct cost in such category, then this requirement will also be satisfied.

No foreign tax credit is permitted for the qualified, exempt income, nor are deductions permitted of expenses related to such income (26 USC \$1.114). 
a few, then there is no (relative) difference in the end. The income actually qualifying for the exclusion from gross income only seems to be a minor part disregarding the billions of dollars it may nevertheless cover - of total extraterritorial income. In his dissenting view on the matter, committee member STARK indicated that this new law would only eliminate the need for a paper subsidiary so that instead of creating an entity in a tax haven, US exporters are enabled to receive the benefit directly. ${ }^{147} \mathrm{He}$ also pointed out that the budgetary tax expenditure of the new legislation - including the repeal of the FSC regime - would increase with $\$ 300$ million annually.

\subsubsection{Failure to Implement (1): the 21.5 Panel}

The EC expressed its concerns about the WTO compatibility of the proposed Act in the spring of $2000 .{ }^{148}$ It was of the opinion that the Act still maintained a subsidy. It considered that there would still be special transfer pricing rules that would lead to part of the export profit arising within the US not being taxed because of its attribution to the partially exempt foreign company. Even after certain alterations to the proposal - such as withdrawing the special transfer pricing rules - there still remained an export contingency since corporations could only be eligible in regard to transactions performed outside the US since sales within the US were not exempt. Moreover, the proposed regime was considered to provide for a subsidy contingent upon the use of domestic over imported goods. ${ }^{149}$

The EC was of opinion that the deadline to withdraw the FSC regime was not met. It considered that the US failed to withdraw the FSC subsidies effectively since the new regime still results in the forgoing of tax revenue and is still contingent upon export performance. ${ }^{150}$ The EC therefore announced its intention to take countermeasures by suspension of GATT concessions. It filed a request for DSB authorisation to impose special charges on certain products from US origin. ${ }^{151}$ The US requested that the matter be referred to arbitration since it was of opinion that the proposed EC countermeasures were not appropriate. ${ }^{152}$ In essence, the US argued that these measures were unnecessary since the FSC regime had been repealed and because the proposed duties were disproportionate to the level of tax subsidy granted.

Next the EC requested the establishment of a 21.5 panel to address among other the SCM Agreement-compatibility of the FSC Replacement Act. ${ }^{153}$ Not only the export-contingency of the tax benefit became an issue, but also the $50 \%$ 
contingency on using US goods over imported goods. Note that the FSC Replacement act now sets a maximum to foreign content instead of requiring a minimum amount of US content (the old FSC requirement). This by itself cannot change the fact that there may be a contingency on the basis of the use of US goods in my opinion.

The EC and the US agreed to suspend the arbitration procedure awaiting the outcome of the panel procedure on the FSC Replacement Act. The original FSC panel would carry out the arbitration as well as the new panel procedure. ${ }^{154}$ There was not to be an entirely new procedure on the FSC Replacement act, but a 21.5 procedure to solve a disagreement on implementation of the recommendations in the FSC report, which - according to the US - were implemented by means of the new Act. 155

The first question the 21.5 panel had to answer was whether there actually was a benefit. It had to determine whether the exclusion of extraterritorial income can be qualified as a situation where no revenue is inherently due or whether revenue is foregone that would otherwise be due. The US argued that by excluding certain income related to foreign transactions from gross income, the prevailing domestic benchmark should be that no tax would be due but for income defined as gross income. ${ }^{156}$ The US argued that it could exclude certain categories of income without violating its WTO obligations. The panel however ruled that - even if income related to foreign transactions could be regarded as a category of income - the selective qualitative and quantitative conditions effectively limited the exemption to only part of such (extraterritorial) income. The panel concluded that revenue was foregone that would otherwise be due.

Next, the panel had to determine whether there was an export-contingent benefit. The ETI regime is not available to property sold for use within the US. It is available for property produced within or outside the US sold for use outside the US. The US argued that US based manufacturers could still qualify for the tax exemption without exporting when they would produce and sell property outside the US. The panel agreed with the view of the European Commission that a subsidy may still be export-contingent even though it can also be obtained in other situations that do not require export. As to the argument brought forward by the US, the panel regarded that this could be regarded as a supplemental feature or an additional subsidy to offshore economic activity. ${ }^{157}$

WT/DS/108/17, circulated 21 December 2000; WT/DS/108/20, circulated 15 March 2001.

See Article 21.5 DSU and paragraph 3.2.3, supra.

Panel Report, United States - Tax Treatment of "Foreign Sales Corporations" (Recourse to Article 21.5 of the DSU by the European Communities), WT/DS108/RW, adopted as modified by WT/DS108/AB/RW, 29 January 2002, paragraphs $8.32,8.37$ and 8.40 .

Ibid., paragraphs $8.60,8.62,8.67$ and 8.70 . In order to effectively remove the export-contingency on the subsidy, the US could grant an equivalent subsidy also to goods for sale or consumption on the domestic market, thus the panel recalled (ibid., 8.71). 
As to the US defence that the ETI exclusion serves as a method to avoid double taxation, which as such could exclude it from the prohibition on the basis of footnote 59 to the SCM Agreement, 158 the panel recalled that the purpose of any measure (or one of its purposes) must be to avoid double taxation in order to qualify for such exclusion. It further recalled that virtually any subsidy provided through income tax relieve may have the accidental effect of preventing double taxation in certain circumstances; such effect would therefore not be sufficient to bring a measure within the scope of the exemption. ${ }^{159}$ The panel noted that the purpose of the Act was extremely broad for a measure to avoid double taxation because it did not require that excluded income would be taxable abroad nor did it set the limits of its application to the type of income that might normally be expected to be subject to tax elsewhere. The panel quite rightly understood from the OECD Model Tax Convention that many countries tax business profits only where an enterprise carries on businesses through a permanent establishment and to the extent those profits are attributable to that establishment. It added that the bilateral tax treaties of the US relied largely on this approach. The Act did exclude income that would rarely be taxable in other jurisdictions, especially the part of the extraterritorial income that is attributable to the domestic activities that took part in the course of the sale or lease transaction. The panel found that it may well be anticipated that the Act may exclude certain income from taxation that could not in any event - be taxed in a foreign jurisdiction, now that there is no requirement that excluded income should be derived from a permanent establishment. ${ }^{160}$ The panel also noted that the Act overlapped with an extensive system of agreements to avoid double taxation. All these elements by themselves could not lead to the conclusion that the Act did not aim at preventing double taxation; taken together they could in the panel's view. ${ }^{161}$

The panel confirmed that the US failed to withdraw the FSC subsidy scheme and therefore failed to implement the recommendations of the DSB. By doing so, it nullified or impaired the benefits accruing to the EC under the GATT and the SCM Agreement. ${ }^{162}$

See paragraph 3.2.1, supra.

Footnote 59 to Annex I of the SCM Agreement; Panel Report, United States - Tax Treatment of "Foreign Sales Corporations" (Recourse to Article 21.5 of the DSU by the European Communities), WT/DS108/RW, adopted as modified by WT/DS108/AB/RW, 29 January 2002, paragraph 8.94

Ibid., paragraph 8.100 .

Ibid., paragraphs 8.97 and 8.98 . The panel also noticed that the extraterritorial income definition does not include a range of income is potentially subject to double taxation, such as transactions with nonqualifying property (ibid., paragraph 8.104).

The panel also determined that the US acted in violation of the Agreement on Agriculture. Furthermore it found that the foreign articles/labour limitation accords the less favourable treatment of imported products over domestic products in violation of article III:4 GATT 1994. 


\subsubsection{Failure to Implement (2): the Appellate Body}

The US sought review by the Appellate Body of the panel's finding that it had failed to implement the DSB prior recommendation and that the exclusion of extraterritorial income is not a prohibited subsidy. In specific, it argued that the panel's finding were in error in regard to (1) the fact that the exclusion of extraterritorial income constitutes the foregoing of revenue that is otherwise, (2) the fact that such exclusion is contingent upon export performance, and (3) the fact that it is not a measure to avoid double taxation within the meaning of footnote 59. ${ }^{163}$

There was tremendous pressure on the US Government to seek review. It had a moral obligation to appeal in order to show to politicians and industries that they have done everything that is in their power regardless of the chance of legal success of such appeal. The Appellate Body, however, upheld the panel's main findings. ${ }^{164}$

As for the issue of the normative benchmark to determine the amount of tax 'otherwise due', the Appellate Body recalled that this will depend on the rules of taxation that each Member establishes for itself. ${ }^{165}$ Panels should compare the fiscal treatment of comparable income to determine whether, for such income, the foregoing of revenue is involved. Since a taxpayer may elect for the ETI regime and have qualifying foreign trade income excluded from tax, instead of a having foreign-source income taxed and being entitled to a tax credit on such income, there will be a foregoing of revenue that is otherwise due. ${ }^{166}$

In regard to export contingency, a subsidy needs to be conditional or dependent upon export performance, either as a sole condition or as one of several others. The requirement that property produced within the US is to be used outside the US implies its exportation from the place of production. It is therefore contingent upon export in the Appellate Body's view, irrespective of whether a subsidy given to property produced outside the US is also contingent upon export. ${ }^{167}$

The Appellate Body pointed out that measures adopted to avoid double taxation of foreign-source income continue to be export subsidies, but they are exempt from the legal regime normally applicable to such subsidies on the basis of footnote 59 .

163 WT/DS/108/21, circulated 15 October 2001. The US also sought review of the findings that article III:4 GATT 1994 was violated as well as the Agreement on Agriculture.

164 Appellate Body Report, United States - Tax Treatment of "Foreign Sales Corporations" (Recourse to Article 21.5 of the DSU by the European Communities), WT/DS108/AB/RW, adopted 29 January 2002, paragraph 256. (Australia, Canada, India and Japan intervened as third parties, requesting the Appellate Body to uphold the Panel's findings in support of the European Commission.)

165 Ibid., paragraph 87. The Appellate Body repeated that "Members have the sovereign authority to determine their own rules of taxation, provided that they respect their WTO obligations." (ibid., paragraph 139). 
The party who asserts the affirmative of this defence bears the burden of proof. ${ }^{168}$ The Appellate Body considered that the scope of this exemption must be defined with great care:
"If footnote 59 were interpreted to allow a Member to grant a fiscal preference for any income that a Member chooses to regard as foreign- source, that reading would seriously undermine the prohibition on export subsidies [...]. That would allow Members, relying on whatever source rules they adopt, to grant fiscal export subsidies for income that may not actually be susceptible of being taxed in two jurisdictions." 169

The Appellate Body therefore decided to look into certain tax treaties and model tax conventions for assistance. The common element it found was that a "foreign" state taxes non-residents on income generated by activities that have some link with that state, i.e. where income is generated by a permanent establishment or by the conduct of a trade or business on its territory. Where there is no such link, it is 'widely accepted' that income will only be subject to tax in the state of residence. ${ }^{170}$ It therefore found that the term "foreign-source income", as used in the footnote, refers to
"income generated by activities of a non-resident taxpayer in a 'foreign' State which have such links with that State so that the income could properly be subject to tax in that State". ${ }^{171}$

The Appellate Body however acknowledges that double tax avoidance is not an 'exact science' and that measures falling under the footnote are not "required to be perfectly tailored to the actual double tax burden". ${ }^{172}$ Member States themselves may determine whether they want to grant any relief of double taxation of "foreignsource income" and to what extent. ${ }^{173}$

It follows from the above that footnote 59 does not provide for an exemption of the prohibition on export subsidies for double tax relief measures that apply to income that cannot be attributed to activities in a foreign state (i.e. to income that arises from domestic activities). On this basis the Appellate Body came to the conclusion that the ETI regime is not in its entirety a measure to avoid double taxation. Although it was of opinion that qualifying foreign trade income had some link to a foreign state (on the basis of the foreign economic process requirements),

169 Ibid., paragraph 140.

170 Ibid., paragraphs 141-144.

171 Ibid., paragraph 145.

172 Ibid., paragraph 146. 
the allocation rules did not distinguish properly between income generated by activities within and outside the US. Rather, the ETI regime's 15 percent and the 1.2 percent rules provided an exemption for a fixed portion of all income earned from a certain transaction, including the part of it generated by activities that took place within the US. ${ }^{174}$

The Appellate Body also noted that taxpayers declaring foreign trading gross receipts up to 5 million US\$ were dispensed from the foreign economic process requirement. The US argued that this was done because of the burden under the requirement that is too great to impose on small taxpayers. The Appellate Body concluded that a portion of income of these taxpayers would therefore be exempt as foreign-source income, even though it has not been established that any activity outside the US has been undertaken. The mere export of a product to another State, for being used there by the buyer, would not be sufficient to conclude that the seller undertook activities in a foreign state where he generated income. ${ }^{175}$ The Appellate Body thus found that although parts of the ETI regime could be considered to fall within the scope of footnote 59 as a measure to avoid double taxation, the regime, as a whole, did not. ${ }^{176}$

On the matter of the withdrawal of prohibited export subsidies without delay, the Appellate Body indicates that this obligation cannot be affected by contractual obligations that the Member State itself may have assumed nor by obligation which private parties may have assumed in reliance on laws conferring such subsidies. ${ }^{177}$ It turned down the US argument that it could continue to grant (unmodified) FSC subsidies in order to protect contractual interest of private parties. It also turned down the transitional period for FSC transaction between 1 October 2000 and 1 January 2002 intended to ensure an orderly transition to the new regime for existing FSC's. ${ }^{178}$

\subsubsection{Failure to Implement (3): the Arbitrator}

The formal adoption of the 21.5 panel's findings and the Appellate Body's report by the DSB reactivated the arbitration procedure to determine the appropriate extent of countermeasures the EC may take. A wide list of targeted US goods and a 4 billion

Ibid., paragraph 165.

175 Ibid., paragraphs 175-176.

176 Ibid., paragraph 186.

177 Ibid., paragraph 230.

178 On the matter of existing FSC's, it has already been addressed that election for FSC treatment was still possible during the entire fiscal year 2000 (ending 30 September 2000). In retrospect the panel should have stipulated that withdrawal of the availability of the FSC subsidy to those who had not yet applied for the regime at the date of adoption of the panel report should be more or less immediate, while maintaining a more lenient withdrawal period for those who already used the regime. In my opinion, Article 4.7 SCM Agreement leaves some leverage to the panel allowing it to take such split decision if well motivated. 
US\$ claim - the amount of FSC expenditure in the year 2000 as derived from the US budget - has been submitted to the DSB by the EC as part of this arbitration procedure, which aims at determining the appropriate level of countermeasures.

The arbitrators considered that footnote 9 to the SCM Agreement provides that the term 'appropriate' is not meant to allow countermeasures that are disproportionate in light of the fact that a subsidy is prohibited. They considered this to be a significant element for their assessment. ${ }^{179}$ The arbitrators then recalled that "the prohibition on export subsidies is a per se obligation, not itself conditioned on a trade effects test." 180 The presence of adverse effects is what makes certain nonprohibited subsidies 'actionable', but there is no reference to 'adverse effects' in the context of remedies for prohibited subsidies. ${ }^{181}$ This difference should be given a meaning in the arbitrator's view. ${ }^{182}$ They considered that in regard to a prohibited export subsidy it is not an option for the infringing Member State to remove the adverse effects and to maintain such subsidy; that Member is rather obliged to withdraw the subsidy without delay. This fundamental distinction between prohibited subsidies and actionable subsidies cannot be disregarded, thus the arbitrators. ${ }^{183}$ Although trade effects may be relevant in order to determine the appropriateness of countermeasures, the arbitrators considered that they are not required to use these effects as a standard for such assessment nor obliged to limit such assessments to these effects. ${ }^{184}$

The arbitrators then mentioned that the objective of countermeasures is to secure compliance with the recommendation to withdraw the FSC/ETI regime

Decision by the Arbitrator, United States - Tax Treatment For "Foreign Sales Corporations" (Recourse to Arbitration by the United States under Article 22.6 of the DSU and Article 4.11 of the SCM Agreement), WT/DS108/ARB, circulated 30 August 2002, paragraph 5.21. The term 'arbitrators' is being used because the actual arbitration was carried out by the original FSC panel that consisted of three persons. The document itself however refers to the decision of the 'Arbitrator'.

Ibid., paragraph 5.23 .

181 Ibid., paragraph 5.33. SCM prohibited subsidy procedure does not contain reference to the extent of nullification or impairment of benefits normally used as a standard in other DSU procedures (Article 4.10 SCM Agreement). Actionable subsidy procedure on the other hand uses the degree and nature of adverse effects for reference (Article 7.9 SCM Agreement).

Ibid., paragraph 5.34 .

183 Ibid., paragraphs 5.38-5.43.

184 Ibid., paragraphs 5.24, 6.34 and 6.35. It is interesting to see that the arbitrators refer to the arbitrators in Brazil-Aircraft, who suggested that it is more likely that the relationship between export subsidy expenditure to the trade effect is rather to be multiplied rather than static, without taking a position on this issue. (Ibid., paragraph 6.42. See the Decision by the Arbitrators, Brazil - Export Financing Programme for Aircraft (Recourse to Arbitration by Brazil under Article 22.6 of the DSU and Article 4.11 of the SCM Agreement), WT/ DS46/ ARB, circulated 28 August 2000, paragraph 3.54.) 
without delay. ${ }^{185}$ They are of opinion that the EC is entitled to take such measures that offset the granting of the prohibited subsidy. Because of the gravity of breaching the prohibition on export subsidies, a certain margin of appreciation is to be granted in the arbitrators' view. ${ }^{186}$ As to the gravity of the breach, special consideration was given to the fact that the FSC/ETI regime was systematically and very widely available. ${ }^{187}$

The arbitrators had to face the fact that the proposed countermeasures would not exactly match the actual benefit to the recipients of the FSC/ETI subsidy. In this respect the arbitrators considered that

\begin{abstract}
"it will, in many situations, be impracticable to devise a countermeasure that would exactly counter the benefits conferred, nor is there, in our view, a requirement to do so, precisely because the terms justifying countermeasures are [...] entitled to be viewed essentially from the perspective of countering the legal breach as a wrongful act. Be that as it may, in the case of a programme such as this [the FSC/ET] subsidy], which applies to firms across a considerable range of industries and products, it is clearly impossible for a foreign government to counter precisely the specific benefits to specific firms. The task of calculation alone would be near impossible, let alone tailoring responses to particular firms. [...] In this instance, the [EC] has based its proposed amount of countermeasures on the face value of the subsidy, rather than directly on the benefits conferred by it."188
\end{abstract}

To the extent the 'benefit' issue is relevant, the arbitrators found no reason to depart from their judgement that using the "expense to government" to determine the level of countermeasures in regard to the prohibited FSC subsidy would not be disproportionate. ${ }^{189}$

The arbitrators further considered that the obligation not to grant prohibited subsidies is owed to each WTO Member in its entirety. They then found that, since the EC is the only complainant, it is entitled to levy countermeasures up to the full amount of 4 billion US\$. It is not obliged to limit itself to it's appropriate share in

Decision by the Arbitrator, United States - Tax Treatment For "Foreign Sales Corporations" (Recourse to Arbitration by the United States under Article 22.6 of the DSU and Article 4.11 of the SCM Agreement), WT/DS108/ARB, circulated 30 August 2002, paragraphs 5.52 and 5.57.

The (adjusted) value of the subsidy in 2000 was determined to be 3.7 billion USS, using the US method of calculation, and 5.3 billion US\$, using the EC's method of calculation. The arbitrators thus found the requested 4 billion USS to be within a reasonable margin of appreciation. It must be noticed that arbitrators are not bound by the calculations made by the parties. (Ibid., Annex A, paragraph A.34.) Ibid., paragraph 6.23. The US did not object to the level of countermeasures addressing this 'benefit' issue. 
trade (according to the US: 1,1 billion US\$ being 26,8\% of the value of the subsidy). ${ }^{190}$ On 30 August 2002, the arbitrators decided that the level of countermeasures proposed by the EC, about 4 billion US\$ in the form of a $100 \%$ ad valorem charge on imports of a number of goods from the US, is to be considered appropriate. ${ }^{191}$

The EC may now ask the DSB to authorise the imposition of these countermeasures. It is rather unlikely that the EC will impose such measures immediately, once it receives this authorisation. It will probably postpone its countermeasures pending a more fundamental WTO-conform revision of its tax system that would bring an end to the present FSC and ETI subsidies. ${ }^{192}$ Negotiation with the US will be in the EC's interest, since countermeasures will most likely affect those European companies that are dependent on imports from the US. And, of course, postponement would give the EC the ability to threaten with the imposition of countermeasures. This can be a useful bargaining chip in other pending US-EC trade disputes.

\subsubsection{The US' Response}

In response to the initiation of the FSC dispute settlement procedure, the US requested consultations with several EC Member States in 1998 regarding certain income tax measures. These proceedings have not yet past the consultation stage. The consultations addressed the following tax measures of the Member States listed: ${ }^{193}$

If there would be more than one complainant it would rather be inappropriate for the arbitrators to allow each of them to impose countermeasures up to the full amount of 4 billion US\$. This would then become a different situation, that would be up to future arbitrators to decide on. (Ibid., paragraphs 6.27 and 6.29). Ibid., paragraph 8.1 .

Chairman Thomas of the House Committee on Ways and Means announced hearings on the WTO's ETI decision. He stated that this decision illustrates the need for a fundamental reform of the US tax system to prevent US businesses from being disadvantaged in international trade. (Press release FC-16 of 19 February 2002.) Thomas introduced a Bill on 11 July 2002 (H.R. 5095) that provides for the repeal of the FSC regime and the extraterritorial income tax regime. At the same time this Bill repeals certain CFC legislation. It has been referred to the House Committee on Ways and Means on 11 July 2002; no progress has been reported.

WTO documents WT/DS127/1, WT/DS128/1, WT/DS129/1, WT/DS130/1, WT/DS131/1; all circulated 11 May 1998. The description of the tax measures at issue is based on the US interpretation thereof as published in these requests for consultations. Even though it was the EC that challenged the US FSC regime, the US invited several EC Member States for consultations, not the EC itself. The reason for this seems to be that the US sought to retaliate within the field of direct taxation, which falls within the competence of the Member States. 
- Belgium; corporate taxpayers receive a tax exemption for recruiting a departmental head of exports ("export manager").

- The Netherlands; exporters may establish an "export risk reserve" for income derived from export sales. ${ }^{194}$

- Greece; an annual tax deduction is available to exporters, calculated as a percentage of export income.

- Ireland; "special trading houses" qualify for a preferential tax rate on trading income from the export sale of Irish-manufactured goods.

- France; (1) companies may temporarily deduct certain start-up expenses of its foreign operations through a tax-deductible reserve. In order to be eligible, the company must have established a branch or subsidiary in a foreign country that is partially owned by a French parent. It must derive more than $50 \%$ of its turnover from sales of products manufactured by the French parent. (2) Companies may establish a special reserve equal to $10 \%$ of its end-of-year receivables to cover medium-term credit risks related to export sales.

No additional information has been released yet. Officially, all procedures are still in a consultation phase even though several years have passed already. Whether the US will demand the establishment of one or more panels depends on the final outcome of the procedures on the FSC and 'extraterritorial income' regime. If the EC would actually introduce countermeasures to the full amount of 4 billion US\$, it is likely that the US will try to get even with the EC. It will probably initiate or continue formal disputes on (alleged) export-related incentives maintained by the EC or its Member States, if such incentive exists at such time of course.

\section{Track I: Countervailing Duties}

\subsection{The Unilateral Duty}

Subsidies included in imported goods may be tackled by one of two methods. First, as we have seen above, it is possible to try and get a state to withdraw or alter its subsidy scheme upon the outcome of consultations or, if necessary, upon recommendation of a panel. Countermeasures may be resorted to if a recommendation is not complied with; they are meant to be a temporary instrument to achieve the implementation of panel recommendations.

The second method will be described hereafter. Instead of trying to get rid of a subsidy scheme, it is possible to levy a duty to neutralise the effect of a subsidy unilaterally. A countervailing duty ('CVD') is levied in order to offset a subsidy included in imports in the manufacture, production or export stage. ${ }^{195}$ The use of 
CVDs is regulated in part V of the SCM Agreement and in Article VI:3 of the General Agreement of Tariffs and Trade 1994 (the 'GATT'). ${ }^{196}$

In order for a CVD to be imposed it must - obviously - be determined that there is a subsidy. It must further be determined that such subsidy is specific and that it results in material injury. There must thus be a causal link between the subsidy and the injury. ${ }^{197}$ It must not only be demonstrated that a countervailable subsidy exists, but it must also be shown that this subsidy was bestowed - directly or indirectly on the manufacture, production or export of an imported product and to what amount. ${ }^{198}$ The term 'subsidy' and the issue of 'specificity' have already been discussed in paragraph 2, supra. The determination of injury depends on the same factors as discussed in regard to actionable subsidies. ${ }^{199}$ Yet, as for prohibited subsidies there is an important difference between track II (the method described in paragraph 3, supra) and track I (the levying of countervailing duties). In track II material injury is irrefutably presumed present. In track I its existence must be proven. ${ }^{200}$ There should be sufficient evidence to demonstrate the causal relationship between subsidisation and injury of the domestic industry. In this respect, other factors that might cause injury, other than subsidisation, should be taken account of in order not to attribute that injury to subsidisation. ${ }^{201}$

Article VI:3 of the GATT provides that a CVD on imported goods shall not be levied,
"in excess of an amount equal to the bounty or subsidy determined to have been granted, directly or indirectly, on the manufacture, production or export of such product in the country of origin or

CVDs may only be imposed in accordance with both Article VI GATT and the provisions of part V of the SCM Agreement. In case of conflict, the latter will prevail. (General Interpretative Note to Annex $1 \mathrm{~A}$ of the Agreement establishing the WTO; Appellate Body, Brazil - Measures Affecting Desiccated Coconut, WT/DS22/AB/R, adopted 20 March 1997, paragraph IV(E)(2); Panel Report, United States - Imposition of Countervailing Duties on Certain Hot-Rolled Lead and Bismuth Carbon Steel Products Originating in the United Kingdom, WT/DS138/R, adopted as modified by WT/DS138/ AB/R, 7 June 2000, paragraph 6.47.)

See Articles 11.2, 19.1 and 1.2 SCM Agreement.

Panel Report, United States - Imposition of Countervailing Duties on Certain Hot-Rolled Lead and Bismuth Carbon Steel Products Originating in the United Kingdom, WT/DS138/R, adopted as modified by WT/DS138/AB/R, 7 June 2000, paragraphs 6.50 and 6.57 .

See paragraph 3.3.3, supra.

See also DIDIER (1999), p. 248 and RODI (2000), p. 130.

Article 15.5 SCM Agreement list factors like "the volume and prices of non-subsidised imports of the product in question, contraction in demand or changes in the pattern of consumption, trade restrictive practices of and competition between the foreign and domestic producers, development in technology and the export performance and productivity of the domestic industry." 
exportation, including any special subsidy to the transportation of a particular product."

Thus a CVD may not compensate for more than the amount of subsidy per imported unit. ${ }^{202}$ It may even be less if a lesser duty would be sufficient to remove the injury to the domestic industry. ${ }^{203}$ The main difference between CVDs and Track II countermeasures is that CVDs may only be imposed on imported goods to the extent necessary to offset the domestic effects of subsidisation of those goods (up to the amount of subsidy granted). ${ }^{204}$ Countermeasures, on the other hand, can be levied on all goods imported from the subsidising Member, including those that are not subsidised themselves. ${ }^{205}$

\subsection{Countervailing Duty Procedure}

The national authorities may launch an investigation into an alleged subsidy in accordance with Article 11 of the SCM Agreement. The investigation will be initiated upon written application by or on behalf of the domestic industry; 206 this application must provide sufficient relevant evidence on the existence of a subsidy (plus, when available, its amount) and the presence of and the link to the injury inflicted upon a Member State's domestic industry.

If the information is accurate and sufficient, the authorities will initiate an investigation. Under 'special circumstances' the authorities may act without any application, provided that they have sufficient evidence of the existence of the subsidy, the existence of material injury and the causal link between them. ${ }^{207}$ If evidence of the presence of the subsidy or injury is insufficient, the investigation must be terminated. Termination must also follow when the subsidy is determined

Article 19.2. SCM Agreement. This second sentence of this article merely provides that it is "desirable" that the duty "should" be less on such occasion; it does not provide for an explicit obligation to do so. However, this sentence may still serve as a guideline for the authorities involved.

205 The latter can not only be used to offset the effect of subsidised imported goods, but also to offset the effect of import substitution and the third-country displacement. Third-country displacement means that a WTO Member may face a reduction in exports when third countries replace their normal imports originating from that Member by subsidised imports from elsewhere. See also Didier (1999), p. 266.

206 The enterprises supporting the application must account for 25 percent or more of the total domestic production of the subsidised good. Furthermore, of the enterprises supporting or opposing the application at least $50 \%$ must be in support thereof. (Article 11.4 SCM Agreement.) 
to be less than 1 percent of the value of the subsidised good (ad valorem). ${ }^{208}$ The investigation must be finished within 18 months after initiation at the latest. Foreign and domestic producers, exporters, importers and interested WTO Members may provide evidence and information in the cause of such procedure if not already asked to do so. ${ }^{209}$ Before determining whether a subsidy is present, the WTO Member whose goods are subject to the investigation must be consulted in order to attempt to agree upon a solution. Provisional measures may be introduced after 60 days during an ongoing investigation for a maximum of 4 months, once the interested Members and parties had the opportunity to provide information and their comments. Furthermore, there must be a preliminary affirmation of the presence of a subsidy and injury and the measures must be necessary to prevent further injury being caused. ${ }^{210}$ Proceeding may end if the effect of the subsidy is limited or the subsidy itself is eliminated by either the granting Member or by the exporter (through an increase in price sufficient to undo the injury). ${ }^{211}$ Whenever it is decided to impose a countervailing duty, it may no longer be in effect once the subsidy is withdrawn.

Retroactive effect of countervailing duties is basically ruled out in Article 20 of the SCM Agreement. However, duties may be levied retroactively for the period that provisional measures have been applied if there has been a final determination of injury for such period. This also applies to a final determination of threat of injury for that period, if, in the absence of the provisional CVD, there would have been a determination of injury. ${ }^{212}$ In case subsidy causes enormous amounts of imports during a rather limited period of time resulting in material injury that is difficult to repair, it is also allowed to levy duties retroactively for a period of 90 days prior to the date provisional measures were enacted in order to prevent the recurrence of injury. In the latter case, only imports designated for consumption are to be subject to such duties.

Any imposed countervailing duty will only remain in force "as long as and to the extent necessary to counteract subsidisation which causes injury". ${ }^{213}$ The competent national authority may conduct an interim review of this duty in order to determine whether the continued imposition of such duty is warranted. A duty must be terminated no later than 5 years after it was first imposed, unless a review investigation is started prior to this deadline. If the outcome of this review would be that expiry of the duty would lead to the continuation or recurrence of subsidisation

For developing countries a higher percentage (up to 2 or 3 percent) may apply. (Articles 27.10 and 27.11 SCM Agreement.)

Article 12 SCM Agreement. Other parties may also be approached, such as industrial users and consumer organisations if subsidised goods are sold at the retail level. 
that causes injury, the imposition of the duty may continue. Then again, there will be a 5 year deadline which can be extended likewise. ${ }^{214}$

All Members must provide at least an annual overview of specific subsidies maintained by them, in order to enable an evaluation thereof by other Members and the WTO's Committee of Subsidies and Countervailing Measures. They must also report actions taken in respect to the imposition of CVDs. ${ }^{215}$

The use of countervailing duties must be regulated in national law, if a WTO Member is planning on levying such duty. Such legislation must provide for an independent judicial, arbitral or administrative tribunal that may review the determinations made by the national authorities; such procedure should be open to all affected parties that participated in the administrative proceedings. ${ }^{216}$ Only a limited number of WTO Member States have actually introduced CVD legislation. For instance, in the EC there is a Council Regulation on protection against subsidised imports from countries that are not a member of the EC and a Guideline on the imposition of countervailing duties. ${ }^{217}$ In the US there is a Federal Regulation on Identification and Measurement of Countervailable Subsidies as part of the Regulation on CVDs. ${ }^{218}$ In the following paragraphs, some fiscal aspects of CVDs will be discussed. Where the SCM Agreement and related documents provide little or no guidance on technical matters concerning fiscal subsidies and CVDs, specific provisions in the aforementioned EC and US regulations will be discussed briefly in order to provide some insight in the practice of these two WTO Members in handling such matters instead.

\section{Track I: Fiscal Aspects of Countervailing Duties}

\subsection{Indirect Subsidisation}

As WESTIN points out, the SCM Agreement does not limit the persons on whom the benefit of a tax subsidy must be conferred. ${ }^{219}$ Even though the SCM Agreement refers to subsidies to manufacturers, it cannot be regarded as certain that this would

Article 21.3 SCM Agreement.

215 Articles 24-26 SCM Agreement.

216 Article 23 SCM Agreement.

217 Council Regulation 2026/97 of 6 October 1997, L 288 of 21 October 1997, pp. 1-33. This Regulation is discussed in-depth by Didier (1999). At some points, the Regulation seems more restrictive in imposing CVDs than the SCM Agreement. The Council (upon proposal of the Commission) will only impose a duty to the level necessary for compensation, even if this would be less than the amount of subsidisation per imported unit. (Article 15(1) of the Regulation). In addition, there will be no duty imposed if this would not serve the Community's interests. (Article 31(1).)

19 Code of Federal Regulation Part 351, Federal Register, vol. 63, no. 227 of 25 November 1998, pp. 6534865418 . 
only include the direct transfer of benefit. I.e. in order to determine whether any (countervailable) subsidy was bestowed on goods produced by certain manufacturers, it must be determined that those manufacturers received a benefit in the end, even if they did not receive the government's financial contribution directly. ${ }^{220}$ For instance a direct tax credit to individuals for putting savings in an investment fund, which then provides easy loans to manufactures can be regarded as a subsidy to those manufacturers. It is not said that such subsidies are therefore specific, since that will depend on the availability of these loans to the different enterprises and sectors of industry.

\subsection{Tax Exemptions, Deductions and Losses}

The method to calculate any benefit must be provided for in national legislation or regulation, including an explanation thereof in order to create transparency. Even though the SCM Agreement does not use the term tax expenditure, it is still this concept that will prove to be of interest. 221 The SCM Agreement provides little guidance in regard to determining the level of fiscal subsidisation. That is why the interpretation of Member States can be of importance. EC and US practice will be looked at briefly in regard to the calculation of fiscal benefits. This will be preceded by reviewing some of the recommendations of the Informal Group of Experts to the WTO Committee on Subsidies and Countervailing Measures on this issue.

The Informal Group of Experts recommended that the cost to the government of tax exemptions, deductions and tax holidays is to be measured as the amount of revenue that would have otherwise have been collected. 222 Yet as we have seen in paragraph 2, supra, the cost to government does not always have to coincide with the amount of subsidy.

An EC guideline on the calculation of subsidy provides that in case of tax exemptions, the subsidy amounts to the tax payable at the standard applicable tax rate. The amount of subsidy of a tax reduction will be based on the difference between the amount actually paid and the amount that would have been paid at the normal tax rate. ${ }^{223}$ In regard to an Indian tax exemption on taxable income from profits realised on export sales, the EC determined in 1998 that the full benefit did

See also Appellate Body Report, United States - Imposition of Countervailing Duties on Certain HotRolled Lead and Bismuth Carbon Steel Products Originating in the United Kingdom, WT/DS138/AB/R, adopted 7 June 2000, paragraphs 58 and 68. 
not only consist of the tax reduction itself. It also includes interest since the nature of this kind of fiscal subsidy is that of a one-time grant. 224

With regard to determining the benefit arising from tax incentives, the US national CVD provisions seem to use the same principles as the EC for a large part. ${ }^{225}$ In case of a full or partial exemption or remission of (corporate) income tax, or a reduction of the tax base, the benefit will be the difference between the tax paid and the tax payable in the absence of the incentive. An exemption of income attributable to economic processes located outside the territory of the exporting country will not be considered an export subsidy as such. ${ }^{226}$ The benefit will exist as from the date the taxes are due; from a US point of view this would normally be the date on which the tax return is to be filed. 227

In the US regulation the issue of subsidies and fiscal losses has also been addressed. ${ }^{228}$ Commentators outlined that the carry forward of losses may confer a benefit if certain companies are allowed to carry forward a greater value of losses than others or to carry forward such losses for a longer period of time than others.

AvI-YONAH has argued that the SCM Agreement may have an important impact on production tax havens that offer a specific tax holiday or alike to attract foreign investors to establish production facilities in the host country. This kind of tax benefit is often ring-fenced in order to prevent erosion of the national tax base. Products are often to be sold outside the territory of the tax haven and not on the domestic market. Such tax haven benefit would therefore often be contingent upon export performance. ${ }^{229}$

\subsection{Tax Deferral}

In case of tax deferral some guidance may come from the SCM Agreement itself. ${ }^{230}$ It states that a loan is not considered to confer a subsidy unless the amount payable on the government loan (including interest) is lower than the amount payable on a comparable commercial loan. Tax deferral can thus result in a subsidy if no commercially like interest is levied.

Commission Regulation (EC) 1204/98 of 9 June 1998, OJ L 166 of 11 June 1998, pp 17-33 and Commission Regulation (EC) 1556/98 of 17 July 1998, L 202 of 18 July 1998, pp. 40-54.

19 CFR 351, FR, vol. 63 , no. 227,25 November 1998, p. $65411, \S 351.509$.

Ibid., p. 65376 .

In comparison, in the Netherlands the taxes are due as from the first day after the end of the fiscal year. If the taxes paid in advance are not sufficient to cover the tax liability, then an interest charge has to be paid along with the remaining taxes due. The date of filing the return can be several months after the end of the fiscal year; the final determination of the tax liability may take several years from then. 
The Informal Group of Experts recommends treating tax deferrals as interestfree loans. ${ }^{231}$ The difference between the appropriate amount of interest and the interest due on the loan would be considered to be the cost to the government and is to be determined on a year-by-year basis. The Group recommends looking at the rate for either short or long-term government bonds of comparable maturity for reference, instead of looking at commercial indicators.

The EC also treats a tax deferral as an interest-free loan. In order to determine an appropriate interest rate, the EC would normally use the interest rate payable on a comparable commercial loan. This is "a loan of a similar amount with a similar repayment period obtainable by the recipient from a representative bank operating in the domestic market." 232 If there is no such comparable loan, the interest rate would be estimated taking the economic situation in general into account (e.g. inflation) and the situation of the recipient in specific. ${ }^{233}$

The US expresses the importance of differentiating between long-term and short-term tax deferral in their national CVD regulations. The appropriate benchmark for determining the fictive interest should be a long-term interest rate and a short-term one respectively. 234

There has been a Korean tax reserve facility that allowed domestic taxpayers that were engaged in foreign-currency earning businesses to establish a fiscal reserve. The maximum annual amount to be reserved was the lesser of half of net fiscal income or one percent of foreign exchange earnings. The reserves was intended to cover possible losses out of export contracts (and cancellations thereof). The part of the reserve that remains after a one-year grace period would have to be returned to taxable income over a three-year period. In 1999 the US calculated the tax savings out of this deferral by multiplying the endof-year amount of the reserve by the statutory tax rate. ${ }^{235}$

WTO document G/SCM/W/415/Rev.2, circulated 15 May 1998, Recommendation 12, Part B, paragraph 100 in reference to Recommendation 9, Part A, paragraph 83.

In comparison: the ECJ ruled that - in order to determine the presence of state aid - a government will not always use the same interest rate as their commercial counterpart because it does not have to make a profit. (See chapter II.1.2.2.)

Commission Guideline, OJ C 394 of 17 December 1998, pp. 6-19.

FR, vol. 63, no. 227, 25 November 1998, p. 65375.

FR, vol. 64, no. 61, 31 March 1999, p. 15534. 


\subsection{Accelerated Depreciation}

The Informal Group of Experts could not reach consensus on recommending a method to determine the cost of accelerated depreciation (i.e. a species of tax deferral). It considered three approaches that will be set forth hereafter. ${ }^{236}$

First, tax savings from accelerated depreciation in a given year could be treated like a grant on a year-by-year basis. This approach would not take into account that more taxes may be due in the years thereafter. ${ }^{237} \mathrm{It}$ is based on the assumption that the tax reductions early on cannot (always) be recaptured at the end of the depreciation period. It recalls that entities that turn unprofitable would incur no tax liability. Furthermore, accelerated depreciation could be effectively "rolled over" when a new accelerated depreciation period starts as a result of purchasing new equipment toward the end of the first period. The assumption that the company receiving the benefit of accelerated depreciation will be free of future tax liability was considered to be a major disadvantage to this approach; it would deny that more taxes may be due in the future.

Second, the difference in taxes could be determined over the entire depreciation period. This approach is based on comparing the tax the company will pay to the tax that it normally would have to pay over the depreciation period. ${ }^{238}$ The present value of this amount at the beginning of the period is considered to be the cost to government. This approach is based on the assumption that the company will pay tax annually. The major disadvantage to this approach is that the true amount of the cost could only be known once that period has ended. ${ }^{239}$

Third, accelerated depreciation could be treated as tax deferral, deeming the interest the government missed on the "loan" to be the cost to government. The Group considered that the "loan" was provided in the year following the depreciation expense, since tax revenue will normally be forgone in the fiscal year

WTO documents G/SCM/W/415/Rev.2/Suppl.1, circulated 1 October 1999, paragraphs 15-16, and G/SCM/W/415/Rev.2, circulated 15 May 1998, paragraphs 52 and 96-98.

For instance, instead of deducting $10 \%$ during 10 years one deducts $25 \%$ during 4 years. In the 6 following years more taxes will be due than normal since there is no deduction anymore.

The US Department of Commerce proposed to change its methodology from using the first approach to this second approach in 1997. This lead to several comments that made the Department decide not to change their methodology for the time being. Most commenters focused on the possibility of changes in tax provisions, tax policies, future tax benefits and the incurring of losses in the future which could lead prevent higher taxes in the future from occurring at all. Also, the administrative burden would become to high using this second approach according to one commenter. Moreover, some commenters argued that it was unlawful to offset tax benefits that are currently countervailable with future higher tax payments. See FR vol. 63, no. 227, 25 November 1998, pp. 65376 and paragraph IV.5.3 supra.

239 The Group also considered that the assumption of annual tax payment would fail to take into account that higher taxes may not be payable in the years after the initial depreciation because of asset replacement or as a result of a company turning unprofitable. 
after a tax subsidy is earned, i.e. the year when the tax return is filed. However, for unmentioned reasons, the Group could neither reach consensus on this third approach.

In determining whether a present value approach should be followed in regard to accelerated depreciation, commentators to a US regulatory proposal pointed out several problems. First, the proposed methodology to take the tax saving in the early years of an asset's life into account as well as tax increases in the latter years is speculative. It is uncertain whether the accelerated depreciation will be offset by higher taxes in the upcoming years, because tax provisions and tax policy may change in the meantime. ${ }^{240}$ Second, this methodology would stimulate the use of tax subsidies instead of discouraging them. Governments could provide for a programme that would offset present (actionable) subsidies in the future. Third, in order to keep track of the companies tax liability the administrative burden would increase. The US Department of Commerce therefore decided not to change their methodology and to assess the tax benefit on a year by year basis.

In my opinion it should be considered that Article 19.2 of the SCM Agreement explicitly states that a CVD "shall be the full amount of the subsidy or less". This does not seem to favour a present value approach. If this Article is interpreted very restrictively, it must be concluded that a CVD cannot cover more than the face value of a subsidy, thus not the interest benefit. If we would still assume a "present value" approach we must consider that this may lead to complications outside the field of accelerated depreciation. Suppose a special tax credit is available upon investment in a certain asset. If such deduction is granted without leading to a decrease in the basis for normal depreciation, such credit will be regarded as a grant. If the acquired asset is used during more than one year of production, this grant must be attributed proportionately.

For instance, a 100,000 Euro tax credit for investment in a machine with a lifetime of 4 years is regarded to be an annual grant of 25,000 Euro per year. However, a lump sum of 100,000 Euro in year 1 is of far greater value to a company than four annual grants of 25,000 Euro each. I.e. as a result of cumulating interest the total benefit over the four-year period will amount to 107,753 Euro (at 5\%), thus approximately 27,000 Euro a year. ${ }^{241}$

WAER and VERMULST point out that the EC categorically classifies accelerated depreciation schemes to contain a grant. However, in some cases it will only result tax benefits and losses might prevent effective higher taxation in the future. See 19 CFR Part 351, FR, vol. 63, no. 227, 25 November 1998, pp. 65375-65376. 
in a delay in payment, i.e. tax deferral. ${ }^{242}$ The extra depreciation allowed under an accelerated scheme will normally lead to lesser possibilities for depreciation in the future, thereby increasing the total tax due in those years compared to the situation of normal depreciation. The proper standard to determine the subsidy would thus be to calculate the interest benefit arising from the deferral, instead of taking the tax benefit in the year(s) of accelerated depreciation.

In a 1999 regulation determining the use of countervailing duties in regard to Korean tax incentives, the EC had to determine whether these tax incentives were specific. WAER and VERMULST address the issue of one of these incentives in particular, the so-called Reserve for Overseas Investment Loss. Any Korean company that invests abroad (either by holding shares in a foreign company or remitting capital to operate a business overseas) may deduct $20 \%$ of the invested amount from its taxable income. The fact that investment abroad was a key requirement for this reserve contributed to the conclusion that the reserve was specific. $^{243}$ The Commission considered that the criterion of overseas investment was not objective, "since it is known in advance that companies which do not invest abroad will be ineligible for the benefit." 244 As WAER and VERMULST point out in response,

"[any] tax measure being dependent on any criterion, however broad, will by definition introduce a distinction, exclude certain tax-subjects from benefiting and accordingly would be specific under current Commission interpretation." 245

It would not matter whatever criterion is used, because it will lead inevitably to some sort of specificity. Does this mean that a reserve for overseas investment loss is always specific as such? In my opinion not. For instance, a cautious approach to determining fiscal income may offer certain opportunities. If it is allowed to take potential risks into account in calculating the fiscal income by objective standards (such as a statistical probability analysis and estimations of potential financial consequences), then it would also be possible to take the risk of overseas investment losses into account if determined by those same standards.

\subsection{Discretion and Thresholds}

In the US' view some measure of administrative discretion occurs in almost every subsidy program, because it has to be determined whether an applicant is entitled to a subsidy based on an evaluation of the relevant facts and merits of an

243 Commission Regulation 619/1999 of 23 March 1999, OJ L 79 of 24 March 1999, pp. 60-95, paragraph 166.

244 Council Regulation 1599/1999 of 12 July 1999, OJ L 189 of 22 July 1999, pp. 1-18, paragraph 83. Eventually, the CVD procedure was terminated because the amount of subsidy was negligible. 
application. If this would be regarded as specific, then it would lead to the 'absurd' result that virtually every subsidy program in the world could be declared specific. Therefore, in order to determine whether a subsidy measure is de facto specific the US will check whether discretion is used in a way that favours one enterprise or sector of industry over another. ${ }^{246}$

In regard to the use of thresholds STANBROOK and BENTLEY argue that a benefit that is provided to all enterprises that have less than a certain number of employees or that have a turnover below a prescribed threshold would in principle not be considered specific. They consider this to be objective criteria that do not favour certain enterprises or sectors over others. ${ }^{247}$ In a US case concerning a Dutch investment tax deduction the US seems to follow their view. Any entrepreneur would be eligible for an investment tax credit if his investment would not exceed a certain amount. If this criterion is met, the receipt of the deduction will follow automatically. This incentive was regarded not to be specific. ${ }^{248}$

\subsection{Attribution of Fiscal Subsidisation}

\subsubsection{Attribution to Imports}

Direct taxation may be a means to pass on a subsidy on imported goods, especially in relation to import and export related incentives. Yet, in order to compensate for such subsidy a countervailing duty cannot be imposed in the form of a direct tax measure. As we have seen, transparency demands the levying of such duty per imported unit.

In most cases direct tax subsidies will not be granted by reference to the number of goods produced, exported or transported. In such cases the EC will determine the amount of duty by attributing the value of the total (fiscal) subsidy over the level of production sales or exports of the product concerned during the period of investigation. ${ }^{249}$

In attributing the benefit from tax incentives to imported products for CVD purposes, the US will look at any relationship between the subsidy and the products. A general subsidy will equally be distributed over all products sold, including exported products. ${ }^{250}$

FR, vol. 63, no. 227, 25 November 1998, pp. 65356.

STANBROOK / BENTLEY (1996), p. 90.

See 61 FR 20406 of 6 May 1996 - notice of preliminary results; 61 FR 47887/47889 of 9 November 1996 final.

Article 7(2) of Regulation 2026/97 of 6 October 1997, L 288 of 21 October 1997, pp. 1-33. If a subsidy is linked to the acquisition of fixed assets, the amount of subsidy will first be spread across the normal depreciation period of such asset in the industry concerned in order to determine the value of the subsidy attributable to the period of investigation. (Ibid, Article 7(3).)

FR, vol. 63, no. 227, 25 November 1998, pp. 65399-65404; 19 CFR \$351.525. 
Korea provided a tax credit to the manufacturing and mining sectors for investments in domestically produced facilities that improved productivity. This credit was 5 to $7 \%$ higher than for foreign produced facilities of such kind. The benefit arising from this difference was attributed to all products sold. ${ }^{251}$ On the other hand, the benefit of an export related tax incentive would be attributed to exported products. ${ }^{252}$ For instance, a tax benefit arising from a deduction of an export allowance from corporate income tax by countries in Trinidad \& Tobago was divided over all export sales eligible for the allowance. ${ }^{253}$ Should a subsidy be market specific (i.e. tied to sales of a subsidised product in a certain market), it will be attributed to the products sold in that market. ${ }^{254}$ Last but not least, any subsidy tied to a specific product will be attributed to that product only. In case of a multi-stage production processes where such product is used as input, the subsidy may also be attributed to the downstream product produced. ${ }^{255}$

\subsubsection{Expenses}

In determining the amount of benefit there may be a deduction of expenses incurred to receive the benefit, such as application fees or deposits according to the US.256 What can also be of interest is whether the costs of the tax lawyer using hours to check the background and to file the application can also be regarded as deductible from the benefit. Do these costs qualify as - in the EC definition - necessarily incurred in order to qualify for or to obtain a tax incentive?257 In case of very complex regulation this should deserve some consideration. From a US point of view these costs will probably not qualify as

"an application fee, deposit or similar payment paid in order to qualify for, or to receive, the benefit of a countervailable subsidy". ${ }^{258}$ 1999, OJ L 79 of 24 March 1999, pp. 60-95, paragraph 139. FR, vol. 62, no. 204, 22 October 1997, p. 55005. Similar Commission Regulation 619/1999 of 23 March 1999, OJ L 79 of 24 March 1999, pp. 60-95, paragraph 139. Ibid. 


\subsection{The Subsidy Benchmark}

The determination of the amount of benefit is especially tricky in fiscal cases. The three examples of CVD cases below may illustrate this, both originating from the EC. Whether the EC will continue its practice set forth hereafter is still to be seen; it will also be interesting to see whether other WTO Members will endorse this practice.

It can be derived from an EC CVD investigation concerning Norway that a differentiated system of direct taxes in administrative zones of a Member State is considered to be specific. ${ }^{259}$ Even though this case addressed differentiated social security rates, the same must be held true for differentiated wage tax rates per zone. The EC did not accept the claim from the Norwegian Government that this was a general tax measure since

"[a] scheme involving different rates of contribution by region is equivalent to a system of reductions and exemptions from a basic tax rate and clearly confers a benefit to those enterprises which qualify for such reductions or exemptions."

The benefit was then determined by comparing the highest regional rate of social security contribution to the lower regional rates.

In my opinion, the EC should rather have used an (weighed) average rate as a comparison, since it is most likely that enterprises in the zone with the highest rate are paying higher contributions in order to compensate for the decrease in contribution in other zones, compared to the situation where one rate would be applied in all zones and the same contribution would have been collected.

The EC also investigated into a Taiwanese tax incentive on investment. Enterprises could get a $20 \%$ income tax credit when purchasing domestically produced automation and pollution control equipment. In case similar equipment would be imported the credit would only be $10 \%$. It was therefore beyond a doubt an import substituting incentive. Then the EC went on with determining the amount of subsidy. It found that the benefit to the enterprise consists of the $20 \%$ tax credit instead of the difference between the $10 \%$ and $20 \%$, because for those kinds of equipment beyond the scope of the tax credit scheme there would be no credit at all. It considered:

"The amount of countervailable subsidies consists of the full amount of tax credits, since the tax credit of $20 \%$ for domestically purchased equipment cannot be considered as a deviation from a standard tax credit rate of $10 \%$. [The] two tax credit rates are considered separate programmes concerning domestically purchased equipment and imported equipment respectively. In the absence of the $20 \%$ tax credit 
for domestically produced equipment, a company would not have received a tax credit. The $10 \%$ credit rate only applies to imported machinery; it is not a general credit rate. Therefore, the Commission concluded that the amount of the subsidy is the total revenue foregone $[\ldots] . " 260$

I find this to be incorrect. The benefit of the subsidy should only be the difference between the $10 \%$ and the $20 \%$ for obvious reasons. If the equipment is not homemade then it is by definition foreign-made or the other way around. I would argue that the benchmark for determining the benefit is to be $10 \%$ and not nil, thus regarding the increase of $10 \%$ to be an extra credit available for home-made equipment.

In another case concerning the same Taiwanese tax credit scheme, the EC even went a step further. It calculated the amount of subsidy on the basis of the amount of taxes unpaid, adjusted by adding the average commercial interest. The Government of Taiwan argued that interest should not be added to the face value of the tax benefit, since the tax credit is only conferred on the date the tax return is made so that there would be no benefit until that date. The EC considered that the benefit consists of a reduction in direct taxes payable every year, so that the benefit will recur annually. Therefore interest should be included. This I hold to be partially incorrect on the basis of the data available, since the tax credit is a one-time only event upon purchase and should not be treated as a continuos benefit, except, of course, when these 'investments' are part of very day business activity. The latter was not provided in the Council Regulation. ${ }^{261}$

\section{Unilateral Counter-subsidies}

Article 32 of the SCM Agreement explicitly states that no specific action is to be taken against a subsidy of another WTO Member, except in accordance with the SCM Agreement and GATT provisions. This restriction can only refer to trade related actions that are normally prohibited by the WTO agreements. It is meant to emphasise that Member States should resort to those measures that have been properly authorised by the DSB.

In this respect BENITAH points out the issue of one Member State introducing a counter-subsidy in reply to an export subsidy of another WTO Member State. ${ }^{262}$ The latter cannot be used as a defence to justify the unilateral introduction of a countersubsidy. The Member State that introduced a counter-subsidy should have taken recourse to and abided by the rules of the SCM Agreement and the DSU instead. ${ }^{263}$ 
Otherwise, allowing such defence "would entail a race to the bottom, as each WTO Member sought to justify the provision of export subsidies on the grounds that other Members were doing the same", thus said the panel in Brazil - Aircraft. ${ }^{264} \mathrm{I}$ could not agree more. Respecting proper procedure is the only way to prevent creating a vicious circle.

\section{Subsidies and Services}

The scope of the SCM Agreement is limited to the subsidy issue in regard to trade in goods. Trade in services in covered by the General Agreement on Trade in Services (the 'GATS'). ${ }^{265}$ Article XV of the GATS provides a mandate to WTO Members to negotiate on the development of some kind of regulation for subsidies on services in order to avoid trade distortion. Little progress has been made in this area since the GATS was concluded. For the time being WTO Members affected by a subsidy on services may request consultations with the subsidising Member, which should give the request 'sympathetic consideration'. ${ }^{266}$

The approach to subsidies in the services sector is dualistic; even though subsidies may undermine trade liberalisation they are also an important tool of social and economic policy. Subsidies in sectors like education and health are of special importance. The GATS emphasises the creation of a subsidy discipline in order to regulate the use of subsidies ex ante, instead of focussing on ex post unilateral remedies. Setting rules about the acceptability of subsidies seems to be the main objective for the Working Party on GATS rules. However, without an 'adequate' enforcement system (based on unilateral remedies) it seems that the committal nature of such rules is open for discussion.

The Working Party on GATS Rules agreed to use the SCM Agreement subsidy definition as a working definition within the field of services. ${ }^{267}$ The application of this definition to services does not appear to pose problems according to the Working Party. It made up a checklist of issues on services-related subsidies some time ago, which serves as a basis for further work and debate. On top of this list is the definition of a "Subsidy in Services" and the relevance of the definition in the SCM Agreement for such purpose. ${ }^{268}$

Panel Report, Brazil - Export Financing Programme for Aircraft, WT/DS46/R, adopted as modified by WT/DS46/AB/R, 20 August 1999, paragraph 7.26.

Governmental services and services in the air transport sector are outside the scope of the GATS.

266 The GATT nor the GATS cover tax subsidies related to passive investment as long as some sort of trade is lacking, such as the provision of services, transfer of intangibles or the sale of goods to foreign subsidiaries, thus Avl-YONAH (2000), pp. 2842-2843.

267 WTO document S/WPGR/W/16, circulated 5 February 1997, as restated in S/WPGR/W/ 25/Add.1, circulated 29 May 2000

Report of the Working Party on GATS Rules to the Council for Trade in Services, S/WPGR/5, circulated 23 November 2000. In a communication from Argentina and Hong Kong, China to the Working Party some 
The Working Party reviewed the trade policy of about half the WTO Members to date and concluded that subsidies in the field of services tend to concentrate in the sectors of audiovisual services, (air and maritime) transport, tourism and banking. ${ }^{269}$ Tax holidays and other fiscal advantages play a specific role in regard to tourism; in this sector there seems to be little cash disbursements. Tax incentives are also used to favour transport, especially shipping companies. A 'recent' trend is the encouragement of the development of financial services through tax incentives and offshore schemes. The Annex to this study provides an overview of the tax incentives granted in the sectors mentioned in the reviewed countries in order to give an indication of the widespread use of such subsidies. Tax incentives are mainly used by less-developed countries as a means of subsidisation in the services sector. Countries like Canada and the EC Member States also subsidise the transport sector and, as for Canada, the tourist sector but they rather use direct grants, preferential credits and state guarantees.

Even though material regulation on subsidies to the services sector is lacking for the time being, it cannot be excluded that such subsidy may have an indirect effect on the trade of goods. If the government would provide a (fiscal) subsidy for services rendered to a certain sector of industry, then such subsidy could be subject to the SCM Agreement if that industry would be able to reduce the price for its goods because of reduced services costs..$^{270}$

comments were made concerning the development of a services subsidy discipline. They proposed among other to ask the WTO Secretariat to do more research into the work of other international bodies in the area of services related subsidies and to do research into the EC state aid jurisprudence and guidelines in regard to services. (WTO document S/WPGR/W/31, circulated 16 March 2000.)

77 Members (out of 144 as of 1 January 2002) have been discussed in the following reports: S/WPGR/W/25, circulated 26 January 1998, S/WPGR/W/25/Add.1, circulated 29 May 2000 and S/WPGR/W/25/Add.2, circulated 12 December 2000. 
The WTO Subsidies Framework 


\section{THE WTO FRAMEWORK VERSUS STATE AID}

\section{Introduction}

Even though the WTO regime and the EC state aid regime must be strictly regarded by themselves, it can be useful to look into some of the potential areas of conflict in case they are to be applied side by side. As BLECKMANN points out the provisions on subsidies arising from the SCM Agreement are to be applied next to the state aid provisions; the fact that a subsidy may fulfil the criteria of one regime does not mean that it will also fulfil the criteria of the other. ${ }^{1}$

The EC Treaty does not provide that the EC State Aid regime as such regulates the use of state aids within the Community exhaustively. There could be room for a subsidy-regulating framework that applies to those aids that already managed to get through the state aid regime in one piece. Such framework could either have an independent status with the need for separate procedures, or it could be integrated in the state aid regime by making that framework part of the set of rules that the European Commission has to abide by.

This chapter will put the regulatory framework of the SCM Agreement ("track $\left.\mathrm{II}^{\prime \prime}\right)$ in a Community context. First, the implementation of track II of the SCM Agreement in the EC will be discussed in paragraphs 2 through 4 . Secondly, a capita selecta of disparities between track II of the SCM Agreement (the subsidy regulation framework) and its Community counterpart - the state aid regime - will be provided for in paragraph 5 .

Whenever the terms 'subsidy' and 'state aid' will be used in this chapter, the first refers to subsidies as defined in the SCM Agreement and the latter to state aids as defined in the EC Treaty. This however does not mean that a state aid cannot be a subsidy or vice versa, since their definitions coincide at least in part. 


\section{Membership of the WTO}

The Member States of the European Union - signatories to the old GATT 1947 - and the European Communities are Members of the WTO. This is in part the result of a conflict in competence, especially in regard to the authority to conclude certain agreements. In its Opinion 1/94 the ECJ ruled that it is the exclusive competence of the EC to conclude international trade agreements like the GATT 1994 determining the common external commercial policy. ${ }^{2}$ However, in regard to other treaties - for instance the agreement on trade in services - the EC's competence was not exclusive so that Member States had to co-sign (and ratify) such agreement. ${ }^{3}$ Therefore, the EC and its Member States are all signatories to the WTO Agreement. Subsequently they are all WTO Members in their own right without any limitation from a WTO perspective.

\section{Non-compliance with the SCM Agreement: Non-EU Member States}

What to do if a non-EU Member of the WTO grants a subsidy in violation of SCM Agreement provisions? Normally, another WTO Member could start proceedings against prohibited or actionable subsidies as described in chapter IV. ${ }^{4}$ However, WTO Member States that are also a Member of the European Communities may not start DSB-proceedings against other WTO Members, because doing so is part of the Community's exclusive competence in the field of international trade. Whenever an EC Member State is faced with trade subsidies from another WTO Member, it (or a representative of its domestic industry) must apply to the Commission to start the necessary procedure on its behalf. ${ }^{5}$ This is based on internal community regulations and not on WTO provisions. ${ }^{6}$

Opinion of 15 November 1994, ECR 1994, I-5267.

Article 133(5) EC nowadays provides for the possibility that the EC can be empowered to conclude trade agreements in the field of subsidies (and intellectual property rights) by a unanimous decision of the EC Council.

4

Most association agreements concluded by the EC (see chapter II, footnote 4) explicitly provide that the granting of subsidies in violation of the state aid prohibition contained in such agreement may be subject to dispute settlement procedures or countervailing duty procedures in conformity with GATT law (i.e. the SCM Agreement).

DIDIER (1999) provides a detailed description of the procedural implementation of the SCM Agreement in the EC in regard to its external application (i.e. the application on subsidies from non-EC Member States). WTO regulations do not limit the right of EC Member States to act like any other WTO Member could do, even in matters where the Community is solely competent. In practice however, EC Member States leave it up to the Commission to protect their interests when it comes to international trade subsidisation in conformity with EC regulations. 
Individual competitors have no standing at all on the WTO level where they are not recognised as a party. Not the industries are a Member of the WTO, but their respective Member States. ${ }^{7}$ Even so, Community-based competitors do have the opportunity to proceed against subsidies from non-EC Members of the WTO. They may request the European Commission to review alleged SCM Agreement violations of WTO Members. The Commission can open an investigation into subsidies once it established that the complaint is sufficiently supported by the Community's sector of industry involved. In special circumstance the Commission can even act without a complaint; it may decide to open an investigation ex officio if there is sufficient evidence to establish the presence of a subsidy and the harm that it causes as to justify such investigation.

The criteria used in an investigation to determine the presence of a subsidy, its effects and the need for CVDs are similar to those set forth in the SCM Agreement. ${ }^{8}$ If the Commission cannot come to an agreement with the subsidising State to withdraw the subsidy or to limit its damaging effects nor to an agreement with the company exporting to the EC to increase its prices to take away the harmful effect of the subsidy, then it may propose to the Council to impose CVDs. It will do so only after determining that the subsidy leads to (competitive) damage and ensuring itself that CVDs will be in the better interest of the Community as a whole. ${ }^{9}$

\section{Non-compliance with the SCM Agreement: EU Member States}

\subsection{Complaining WTO Member States}

If an EC Member State would introduce prohibited or actionable subsidies, another WTO Member could start one of the procedures set forth in chapter IV. It is irrelevant whether or not the Commission approved of such subsidy as part of its state aid competence. Such approval does not stand in the way of WTO dispute settlement procedures.

See StANBRoOK / Bentley (1996), p. 90.

8 Council Regulation (EC) 2026/97 of 6 October 1997 on protection against subsidized imports from countries not members of the European Community (OJ L 288 of 21 October 1997, pp. 1-33) still contains a category of subsidies called 'non-countervailable' subsidies. This is similar to the SCM Agreement's former category of non-actionable subsidies (especially subsidies related to research and development, to disadvantaged regions or to environmental improvements of facilities). See chapter IV.3.1.

It is possible to impose provisional CVDs in the course of an investigation to prevent further harm to be inflicted, since the investigation may carry on for about a year. The detailed regulation itself is provided in Council Regulation (EC) 2026/97 of 6 October 1997 on protection against subsidized imports from countries not members of the European Community, OJ L 288 of 21 October 1997, pp. 1-33. For more information see DIDIER (1999). 
WTO Members that want to bring a subsidy that is regarded to be 'approved state aid' to the attention of the DSB have to proceed against the granting EC Member State. The Community itself will not have to face SCM procedures because the Commission may or may not have approved of a national state aid. ${ }^{10}$ Although the Member State itself will be the defending party in any dispute, it is common practice for the Commission to act as its representative in a WTO dispute settlement procedure.

\subsection{Community-based Competitors}

Suppose we have an enterprise, a resident of one of the EC Member States, that operates on the Community Market. Its attempt to keep the Commission from approving a subsidy of another EC Member State for an important competitor was unsuccessful. However, the enterprise is of the opinion that this subsidy violates the track II provisions of the SCM Agreement. Could it invoke these provisions in annulment proceedings?"1

The Council accepted the WTO Agreements under Article 300 EC. Subsequently, these agreements have become an integral part of community law and they now bind the Community and its Member States..$^{12}$ However, the ECJ is reluctant to allow individuals to call upon WTO provisions in Community courts.

In the 1999 Portugal case the ECJ considered the danger that the Community and its Members could not use the authority to negotiate as foreseen in the WTO dispute settlement procedure if it would grant WTO provisions direct effect. ${ }^{13}$ The ECJ considers that the Community institutions are free to agree with non-EC Members what effect the provisions of an agreement are to have in the internal legal order of the parties to such agreement. If this has not been settled by the agreement, then it is up to the Community Courts, and the ECJ in particular, to decide the matter. Parties must be bona fide in the performance of any agreement, although the manner in which they execute such agreement in their legal system is for them to decide, unless the agreement itself provides specifications on this matter. ${ }^{14}$ As to the matter of direct effect, the Council made a clear statement. The preamble of the

In comparison, the EC may be considered the granting WTO Member in regard to subsidy out of Community funds.

The competitor could also be in need to fall back on SCM provisions when a subsidy falls outside the scope of the state aid regime. For a view on the position of individual traders and the direct effect of the WTO Agreements in general, see KUILWIJK (1996).

ECJ C-149/96 of 23 November 1999, Portugal v Council, ECR 1999, I-8395. Recall that a WTO Member may mutually agree upon a solution in case of a Treaty violation as part of the consultation-phase.

ECJ C-149/96 of 23 November 1999, Portugal v Council, ECR 1999, I-8395, paragraphs 34-35; ECJ 104/81 of 26 October 1982, Hauptzollamt Mainz v Kupferberg, ECR 1982, p. 3641, paragraph 17-18. 
Council decision concerning the conclusion of the 1995 WTO Agreements (including the GATT 1994 that succeeds the GATT 1947) states:

“... by its nature, the Agreement establishing the World Trade Organization including the Annexes thereto, is not susceptible to being directly invoked in Community or Member State courts" ${ }^{15}$

The WTO Agreements still leave considerable room for negotiation between parties in resolving disputes, thus the ECJ. It further considers that, even though there is a preference for full implementation of panel recommendations, the dispute settlement understanding leaves room to offer interim compensation if the immediate withdrawal of WTO-incompatible measures is impracticable. Also, parties may negotiate for the purpose of finding a mutually acceptable compensation instead of having to withdraw the measures. If the ECJ would be forced to uphold the WTO Agreements itself, it would therefore deprive the legislative and executive organs of the Community of the possibility to negotiate such arrangements.

I agree with DESMEDT that the option to compensate does not accord a 'right' to violate provisions in these Agreements. Rather, compensation is a practical alternative to temporarily defuse a dispute. ${ }^{16}$ The fact that this option exists, should not influence the status of the WTO Agreements in the EC's internal legal order where Community acts are expected to be in conformity with the obligations under the WTO agreements on the basis of Article 300(7) EC. ${ }^{17}$ When there are obligations imposed on a group of states by mutual agreement, then these states must be deemed to have committed themselves to comply with those obligations, unless the non-committal nature of the obligations is explicitly agreed upon in the concluded Agreement itself. In regard to the WTO Agreements, Article XVI:4 of the Agreement establishing the WTO provides for the contrary:

"Each Member shall ensure the conformity of its laws, regulations and administrative procedures with its obligations as provided in the annexed Agreements."

Should one of the participants not comply, then it depends on the agreement whether an adequate remedy procedure is provided. Unilateral measures like suspension of the fulfilment of obligations must be used as a last resort, but only in case an adequate remedy procedure is absent. ${ }^{18}$ In regard to the ECJ's finding that the WTO Agreements are partially based on reaching a mutual understanding 
between parties, it must be considered that most national courts will probably expect parties to try to find a mutually acceptable solution for their problem first before starting court proceedings. The complaining party may settle for a financial buy-off instead of pursuing the withdrawal or alteration of an aid; in national laws it is often accepted that parties try to reach pre-trial settlement.

Apart from the availability of the option to grant compensation, the ECJ considered that the most important trading partners of the EC do not recognise the WTO Agreements to be among the rules by which their judicial organs are to review the legality of acts in their domestic laws. This potential lack of reciprocity was one of the most important arguments not to allow direct effect in the Community either. On the matter of intra-community direct effect the ECJ therefore concluded that

\begin{abstract}
"having regard to their nature and structure, the WTO agreements are not in principle among the rules in the light of which the Court is to review the legality of measures adopted by the Community institutions. [...] It is only where the Community intended to implement a particular obligation assumed in the context of the WTO, or where the Community measure refers expressly to the precise provisions of the WTO agreements, that it is for the Court to review the legality of the Community measure in question in the light of the WTO rules". 19
\end{abstract}

The ECJ calls to mind that its interpretation corresponds with the aforementioned statement in the preamble of the Council's decision to adopt the WTO Agreements. This observation seems to neglect the fact that the preamble only contains a unilateral statement for internal Community purposes that is not part of the concluded agreement itself. ${ }^{20} \mathrm{I}$ am of opinion that the preamble cannot override the clear verbatim text in Article 300 (7) EC, neither can the fact that it is standing practice in some of the WTO Member States not to grant direct effect. Yet, the ECJ is very clear in not allowing individuals to rely on provisions in the WTO Agreements Community legislation intends to implement a WTO obligation when it refers to a precise WTO provision, those WTO provisions may prevail over Member State laws and secondary community law, but not over primary law like the EC Treaty considering articles 300(5) and (6) EC. The aforementioned exemptions were already set forth in regard to the GATT 1947 in ECJ 70/87 of 22 June 1989, Fediol v Commission, ECR 1989, p. 1781 and ECJ C-69/89 of 7 May 1991, Nakajima v Council, ECR 1991, I-2069. 
in EC Courts for the time being, except when WTO provisions are implemented in or referred to by EC law.21

In regard to the SCM Agreement, it has not been referred to by nor implemented in EC law in respect to its application on EC Member States. State aid regulations contain no direct reference to SCM Agreement provisions nor do they express the intention to provide a regime that is in compliance with that Agreement. Therefore, our competitor will not be able to call upon SCM Agreement provisions in order to have a Commission decision annulled.

As HILF and SCHORKOPF conclude a strange situation has evolved. Though there is a mechanism in place in regard to extra-Community subsidies that are incompatible with the SCM Agreement, 22 a similar mechanism to control the legality of the internal commercial politics of the Community itself and its Member States is refused. ${ }^{23}$

\subsection{Community-based Beneficiaries}

Beneficiaries should be protected from being offered approved aid that is in violation of binding SCM Agreement provisions. The approval of an aid by the Commission could provide such beneficiaries with a false sense of security on such occasion. I cannot but agree with KUILWIJK when he argues that

"[the] risk that [Community] institutions simply cannot be bothered to obey the rules of GATT to which they voluntarily have committed themselves is not one of the mere commercial uncertainties that unavoidably characterise all forms of economic activity. It is a risk that EC traders do not have to accept." 24

Especially when repayment of subsidies would be accepted as part of the SCM Agreement regime, there is a direct concern for the recipient of a subsidy not to be faced with an approved state aid that turns out to be WTO-incompatible. The Commission could consider using an SCM-Agreement-compliance test next to its normal criteria for state aid approval, in order not to let a non-compliant subsidy pass. The introduction of such official test - as an integrated part of the state aid regime - is merely theoretical, because it would provide a legal basis for

The ECJ will neither allow Member States to rely on WTO Agreements in EC Courts when neither the Fediol exemption (intent to implement a WTO obligation) nor the Nakajima exemption (referral to precise WTO provisions in EC Law) applies, in conformity with its GATT 1947 doctrine. See ECJ C-280/93 of 5 October 1994, Germany v Council, ECR 1994, I-4973, paragraph 111, in reference to ECJ 21-24/72 of 12 December 1972, International Fruit Company v Produktschap voor Groenten en Fruit, ECR 1972, p. 1219. In the latter case the ECJ first ruled against direct effect of the GATT 1947 for individuals. 
competitors to invoke SCM provisions in the Community Courts. Taking account of the statement in the aforementioned preamble to the Council's decision concluding the WTO Agreements, this seems politically unacceptable.

\section{Capita Selecta of Disparities between Track II and the State Aid Regime}

\subsection{Similarities and Differences}

The number of cases in which approved state aids will actually violate SCM Agreement provisions will be relatively small. The EC's state aid control mechanism is very strict and uses for the most part criteria that are comparable to those of the SCM Agreement. WISHLADE points out the four most obvious similarities between both frameworks. First, their aim is at transactions from or on behalf of governments. Second, both frameworks are indifferent to the form of any subsidy measure. Third, an advantage to the recipient is required by both be it under the term 'benefit' in the SCM Agreement or the term "favoured" in the state aid regime. Fourth, either framework requires some sort of specificity. ${ }^{25}$

Before looking into the differences between the track II of the SCM Agreement and the EC State Aid regime, it is important to consider that the SCM Agreement only applies to goods-related subsidies and not to services-related subsidies. The State Aid regime on the other hand applies to both kinds of subsidies. Furthermore, the SCM Agreement can only be invoked by non-EC Members of the WTO when a certain subsidy affects the extra-community trade of goods or the import of goods into the EC. These differences in scope do substantially limit the impact of the SCM Agreement.

The most important difference in the nature of the WTO's Subsidy regime and the EC State Aid regime is the concept of prohibition. Under the EC's regime all aids that fulfil the definition of Article 87(1) EC are prohibited, unless the Commission (or the Council) approves them. On the other hand, the SCM Agreement only prohibits subsidies stimulating export or import substitution (in principle without the possibility to derogate). Other kinds of subsidies are not prohibited ex ante, but they can be acted against when trade is affected. ${ }^{26}$

In fact, the EC's regime will often be more strict than the SCM Agreement because of its broad definition of state aid and the detailed requirements in the extensive regulatory framework that is available. Even so, there are instances where the SCM Agreement provides limitations on subsidisation that are stricter than those adhered to by the Commission. The following paragraphs will try to provide an overview of the more restrictive SCM Agreement provisions, in order to define areas of conflict where even approved state aids could still be at risk being subject to DSB procedure. 


\subsection{De Minimis Aid}

In practice, the EC as well as the WTO do not allow any de minimis waiver in regard to export-related subsidies. In regard to actionable subsidies, the WTO does neither provide for a de minimis waiver. When trade is affected by a subsidy as spelled out in the SCM Agreement, action can be taken against such subsidy regardless of its size. The Commission however applies a general de minimis waiver, assuming that small aids do not affect trade (with the exception of export related aids). ${ }^{27}$ The issue of non-compliance with the SCM Agreement may be of special importance to these de minimis aids. Since there will hardly be any ex ante review of de minimis aids on the EC level an SCM Agreement violation is more likely in comparison to aids that did get trough state aid procedure. However, these de minimis aids are unlikely to be subjected to WTO procedure in ad hoc cases taking account of the cost and time involved in such procedure for the complaining State. ${ }^{28}$ On the other hand, proceeding against de minimis aid schemes that favours an entire sector of economy may still be worthwhile if one looks at the potential cumulative size of all aids granted under such scheme.

\subsection{Lack of Common Interest}

As we have seen in chapter II.2, certain kinds of government aids are compatible with the EC's state aid framework because of their objective. Think of regional development aid, environmental aid, aid to SMEs, disaster relief aid etcetera. These aids may be approved by the Commission or may already have been excluded from notification because of their beneficial effect from a Community perspective. The SCM Agreement does not provide a list of 'acceptable' subsidies. ${ }^{29}$ It is not being said that these kinds of aid are by definition actionable, because it must still be established whether there are adverse effects. ${ }^{30}$ This is where the difference between the EC's and the WTO's framework is best visible: aids that are allowed in the Community's better interest cannot be regarded to serve a sort of WTO's interest

For details see chapter II.3.3.2.

Consider that the EC's de minimis exemption does not apply to export aids. For an ad hoc de minimis aid to be subjected to a prohibited subsidy procedure, it would therefore have to be conditioned upon import substitution. It will be rather hard to prove a perceptible influence on trade in order to be able to trade a non-prohibited, ad hoc de minimis aids as actionable.

As we have seen in chapter IV.3.1, there has been a category of 'non-actionable' subsidies in the SCM Agreement until 31 December 1999.

Unless of course there would be a prerequisite in the field of export or import substituting activities, which would qualify such aid as prohibited. 
also. ${ }^{31}$ These aids must be tested against the SCM Agreement's actionable subsidies criteria; they cannot be considered safe without hesitation.

For example, it may be in the common interest of all EC Member States to (de jure) approve of aid to assist less developed regions in the EC, but it is still highly questionable whether other countries outside the EC - especially developing countries - would share such commitment. On the other hand, though the WTO does not exclude disaster relief aid from the scope of its actionable subsidies regime it seems unlikely that such aids will become the subject of a dispute settlement procedure. ${ }^{32}$ Acting against temporary or one-time-only subsidies that are merely meant to compensate for extraordinary costs resulting from severe flooding (beyond the normal risk enterprises are expected to bear) or earthquakes would be politically not done, yet there is no legal barrier for other WTO Members to start a dispute settlement procedure..$^{33}$

\subsection{Enforcement}

An important difference between a prohibition of a subsidy based on the SCM Agreement instead of Article 87(1) EC is the effectiveness of enforcement. In case an EC Member State does not comply with the abolishment and recovery of state aid, the Commission may ask the ECJ to impose penalty payments. In comparison, the DSB may authorise the use of countermeasures by the complaining WTO Member State. The effectiveness of such temporary measures to enforce panel decisions largely depends on the importance of access to the domestic market of the 'winning' state to the industry of the 'losing' state. If the market of the winning WTO Member is of (nearly) no importance, then such countermeasures will probably not provide the necessary economic pressure for enforcement. For instance, the imposition of quotas on the import of European cars by the US will have a far more important economic effect than similar quota's imposed by the Fiji Islands. Even so, the domestic and international political impact of a DSB decision to authorise the use of countermeasures may still play an important role in convincing a WTO Member State to comply with panel recommendations. project of common European interest. See chapter II.2.3.3. if such relief is made available to anyone in the disaster area as a form of general assistance. (FR, vol. 63, no. 227,25 November 1998, p. 65407,19 CFR \$351.502(f).) 
A second, obvious difference in enforcement is that the SCM Agreement provides the opportunity to impose unilateral duties to offset the effects of subsidies on imports. In the EC on the other hand unilateral action of this kind is not allowed. It is up to the Commission (and the EC Courts) to enforce EC state aid provisions.

\subsection{Recovery $\neq$ Recovery}

I cannot but wonder whether the WTO panel in the Australian Leather case took the EC's state aid regime as a sort of example, when deciding upon the issue of recovery of prohibited export subsidies. ${ }^{34}$ There are some similarities between the panel's reasoning used to determine that recovery is part of the WTO's subsidy control mechanism, and the reasoning the ECJ used to determine that the Commission had the implicit power to order recovery. Both were concerned with interpreting the scope of application of the term 'withdrawal' as a useful remedy for illegal subsidies (or in EC terms: incompatible aids). The ECJ's reasoning will be set out in chapter VI.

Considering the European Commission's strict position on ordering recovery of state aid, it may be of interest to look how the Commission felt about recovery on the WTO level. In the Australian Leather case, the Commission argued that there could be no obligation to remedy violations with retroactive effect. Any such obligation would be ineffective, since it would result in interference with private rights, giving rise to domestic legal claims. ${ }^{35}$ Apart from the panel's conclusion that this concern would also arise in case of prospective repayment, one cannot but wonder why the Commission does so easily set aside this issue it addressed itself when it comes to recovery of state aid. The Commission's concerns in regard to recovery of state aids within the EC will be presented in the next part of this study.

Panel Report, Australia - Subsidies provided to Producers and Exporters of Automotive Leather (Recourse to Article 21.5 of the DSU by the United States), WT/DS126/RW, adopted 11 February 2000, paragraph 6.23 . 
The WTO Framework versus State Aid 


\section{FISCAL RECOVERY}

\section{A Matter of Certainty}

"The certainty of what each individual ought to pay is, in taxation, a matter of so great importance that a very considerable degree of inequality, it appears, I believe, from the experience of all nations, is not near so great an evil as a very small degree of uncertainty."

\section{Adam Smith}

An Inquiry into the Nature and Causes of the Wealth of Nations, 1776, Book V, Ch. 2 
Chapter VI

\section{RECOVERY OF UNLAWFUL TAX INCENTIVES WITHIN THE EC}

\section{The Implicit Power to Recover}

A basic introduction into the procedure of state aid recovery has already been provided for in chapter II.4.2.6. In this chapter we will look into the recovery issue in-depth. Of special interest are the national implications of effectuating recovery. Several aspects thereof will be discussed in paragraphs VI.2 through VI.7. This paragraph will look into the legal basis of recovery.

Article 88(2) EC refers to the power of the Commission to decide that a Member State shall abolish or alter incompatible aid within a certain period of time. ${ }^{1}$ This seems to indicate an ex nunc correction by abolishment or alteration of an aid for the future instead of recovery ex tunc. ${ }^{2}$ Even so, in order to eliminate incompatible aid effectively recovery can be necessary to undo the effects from aids already granted without the necessary approval. The ECJ therefore determined that a power to recover is implied by Article 88(2) EC, since the Commission must be able to determine the effect of its decision when it tries to secure compliance with the Treaty. ${ }^{3}$ The elimination of unlawfully granted aid through recovery of such aid (plus interest) is the logical consequence of the decision that it is incompatible aid because recovery tries to restore the situation as it existed before the granting of the aid. Doing is in not disproportional to the objectives of the EC Treaty in regard to state aid, thus the ECJ and the CFI. ${ }^{4}$

The same applies to the misuse of approved state aids.

Also Stolba (1999), p. 232.

Cf. ECJ 70/72 of 12 July 1973, Commission v Germany, ECR 1973, pp. 813ff.

EC] C-142/87 of 21 March 1990, Belgium v Commission (Tubemeuse), ECR 1990, 1-959, paragraph 6; EC] C-169/95 of 14 January 1997, Spain v Commission, ECR 1997, I-135, paragraph 47; CFI Joined Cases T298/97, T-312/97, T-313/07, T-315/97, T-600-607/97, T-1/98, T-3-6/98, T-23/98 of 15 June 2000, Mauro Alzetta et al. v Commission, ECR 2000, II-2319, paragraph 169. See also ECJ C-382/99 of 13 June 2002, The Netherlands v Commission, not yet published, paragraph 89. 
The power to recover is thus considered to be inherent to the Commission's power to declare an aid incompatible and to require its abolishment, although this does not follow explicitly from the verbatim text of article 88(2) EC. Director General SCHAUB of DG Competition emphasised that

\begin{abstract}
"recovery $[\ldots]$ was an idea of the Commission. Today it may appear to be a very obvious solution - indeed, recovery of an incompatible aid is the best possible way to restore fair competition - but given the lack of legal provisions, it was certainly not obvious at the time [the mid1980 s]." 5
\end{abstract}

If we consider recovery to be the logical consequence of finding an aid incompatible, then it seems odd that until 1984 this logic was not as evident as it seems nowadays. In practice, the systematic use of the recovery instrument did not start until the mid-1980's. It seems that this instrument was introduced in an attempt to stop the increase in unnotified state aids back then. ${ }^{6}$ The procedural regulation nowadays obliges the Commission to use its power to recover unlawful aid, unless it would violate a general principle of community law (read: the protection of legitimate expectations) by doing so. ${ }^{7}$

Regretfully, the Commission may not order the recovery of aid that is compatible with the Common Market, even when it was granted in violation of the article 88(3) EC stand-still provision. ${ }^{8}$ We must keep in mind that a financial benefit may result from receiving any aid - compatible or incompatible - prior to its approval by the Commission. Even in regard to compatible aids one cannot deny that granting an aid during the stand-still period may lead to a financial advantage that would not have been present when the stand-still would have been observed.

Declaring a prematurely granted aid compatible cannot remedy the fact that it has been granted in contradiction to the standstill clause of Article 88(3) EC. ${ }^{9}$ Such Commission decision cannot retroactively lift the unlawfulness of the aid for the period prior to its approval. Effective enforcement of Article 88(3) EC therefore requires a legal basis for the Commission to order compensatory interest payment in order to undo the interim benefit from receiving aid too soon. Article 88(2) EC does not provide for such basis in case aid is declared compatible although it was

Speech at the State Aid Forum, Copenhague, 26 January 2001.

Cf. SINNAEVE (1997), pp. 65-66. An extensive overview of the history of recovery in matters of state aids can also be found there.

Council Regulation EC 659/1999, OJ L 83/1 of 27 March 1999, Article 14(1). Also see paragraph 4, infra.

Except when it is most obviously seemed to be incompatible at first, then a recovery injunction would have been possible.

Also see ECJ C-354/90 of 21 November 1991, Federation Nationale du Commerce Exterieur des Produits Alimentaires and Syndicat National des Negociants et Transformateurs de Saumon v France (French salmon), ECR 1991, 1-5505. 
granted prior to the final approval. Its verbatim text restricts recovery actions to aid that is either 'not compatible' or that is being misused. Since this leaves no room for an analogous interpretation from my point of view, a change in the text of the Treaty would be required to create the necessary legal basis.

Both Advocates-General TESAURO and JACOBS come to the conclusion that it should be possible to recover aid that is unlawful as a result from breaching Article 88 (3) EC even when the Commission rules in favour of its compatibility..$^{10}$ As JACOBS puts it, it would be inconsistent with the notification and standstill duties from Article 88(3) EC if a Member State would not have to face sanctions once he ignores those requirements. ${ }^{11}$ For this reason, I plead that recovery of the interim benefit should be strictly observed by itself and should not depend on the compatibility of the underlying aid. By accepting an aid during the standstill period (of which a diligent businessman is deemed to be aware, as we will see) the recipient himself contributed to the violation of proper procedure. Some sort of neutralisation of the interim-benefit would therefore not be out of place if one compares it to the regime of full recovery.

Another problem with recovery is that - once a recovery decision has been taken - the Commission is not held to enforce it by commencing infringement proceedings at the ECJ. ${ }^{12}$ Even though the Commission is obliged to recover, this obligation only goes as far as taking a decision ordering recovery. Since insurmountable difficulties in recovery must be solved in joint co-operation between the Member State and the Commission, the latter could show temporary lenience if it has compelling reasons to do so taking the interests of the Community and the other Member States into account. The Commission could also decide to give recovery in a specific case a very low priority. Competitors cannot call upon the ECJ to force the Commission to start proceedings to force actual recovery, since they are not the addressees of any potential decision to start proceedings. ${ }^{13}$ Nor can they bring an action under Article $232 \mathrm{EC}$, since there is no breach of the Treaty when the Commission does not act when it is not obliged to do so. ${ }^{14}$ However, it seems that Member States still stand a chance in Article 227 EC proceedings, because non-compliance with the recovery decision would lead to a failure to fulfil a Treaty obligation on the side of the granting Member State. 12, and Opinion of 4 October 1989 in case C-301/87 of 14 February 1990, France v Commission (Boussac), ECR 1990, I-307, paragraph 43. Ibid., paragraph 34. See CFI T-277/94 of 22 May 1996, AITEC v Commission, ECR 1996, II-351, paragraph 28-29 in reference to ECJ 247/87 of 14 February 1989, Star Fruit Company v Commission, ECR 1989, 291. 


\section{National Procedural Autonomy}

As STOLBA recalls, recovery is a matter of national procedural regulation as long as there are no provisions set at the EC level by means of a regulation. Even though there is an obligation to recover for Member States, a recovery procedure is not provided in Community Law itself. ${ }^{15}$ It is still a matter of national procedure to regulate the relation between the Member State and the beneficiary. This must be done in such manner that the Member State can fulfil its obligations arising from the Treaty and the Commission's state aid decisions.

The ECJ set the borderlines for the application of national procedure to state aid recovery. In principle, recovery of state aid must take place in the same way as the recovery of other government held debts from entrepreneurs. The first limitation is that these rules may not be less favourable than the regulations applying to recovery of normal government debts; the so-called equivalence principle. The second limitation is that the rules for state aid recovery should not render recovery practically impossible; the principle of effectiveness. ${ }^{16}$ The latter principle plays an important part in regard to the strict requirements to legitimate expectations and the circumstances under which they may be recognised. ${ }^{17}$

To what extend national provisions have to be set aside when they make recovery impossible, is open for discussion. Whether this would lead to applying national procedure excluding those provisions that restrict recovery or whether this would lead to applying something other than national procedure is yet unclear. The latter could only be a Community backup procedure for recovery, but that does not exist at present. Instead of setting aside existing national provisions that stand in the way of recovery, there is an alternative, namely (retroactively) enacting new legislation to make actual recovery possible.

It follows from the San Giorgio case that the principle of effectiveness prevails over the equivalence principle in case of conflict. ${ }^{18}$ This would mean that in order to ensure the effectiveness of Community law other (procedural) standards may apply than in regard to national recovery issues. However, the San Giorgio case concerned an individual that was hindered by national procedure to retrieve certain sums levied in violation of Community Law from the government and not the other way around. Yet, the Member States' obligation to co-operate with the Commission may

ECJ C-142/87 of 21 March 1990, Belgium v Commission, ECR 1990, I-959, paragraph 61; ECJ 94/87 of 2 February 1989, Commission v Germany, ECR 1990, 175; ECJ C-5/89 of 20 September 1990, Commission v Germany, ECR 1990, 1-3437; ECJ C-382/99 of 13 June 2002, The Netherlands v Commission, not yet published, paragraph 89. Also see LENAERTS / ARTS (1999), p. 96.

Also see BARDENHEWER (1995), p. 242, who argues that the claim for effectiveness of community law cannot be so important that the legitimate interests of individuals could more or less be set aside.

ECJ 199/82 of 9 November 1983, Amministrazione delle Finanze dello Stato v San Giorgio, ECR 1983, p. 3595 . 
go as far as creating new and effective recovery procedures. The duty to alter national procedures at the disadvantage of the beneficiary follows from the principle of Community loyalty set forth in Article 10 EC, which orders Member States to

\begin{abstract}
"take all appropriate measures, whether general or particular, to ensure fulfilment of the obligations arising out of this Treaty or resulting from action taken by the institutions of the Community $[\ldots]^{\prime \prime} .{ }^{19}$
\end{abstract}

The wording of this principle is neutral; it may well urge Member States to create new recovery procedures notwithstanding that other principles of Community law like the protection of legitimate expectations and legal certainty - to be discussed in paragraph 5 hereafter - may (theoretically) stand in the way of effectuating recovery. The ECJ held that
"the Commission and the Member State concerned must respect the principle underlying Article [10 EC], which imposes a duty of genuine cooperation on the Member States and the Community institutions, and must work together in good faith with a view to overcoming difficulties whilst fully observing the Treaty provisions, and in particular the provisions on aid. [...] [The] German Government merely informed the Commission of the political and legal difficulties involved in implementing the decision, without taking any step whatsoever to recover the aid from the undertaking in question and without proposing to the Commission any arrangements for implementing the decision which would have enabled those difficulties to be overcome." 20

In some countries creating a retroactive basis for levying taxes faces a constitutional dilemma. The ECJ addressed the latter issue from a practical perspective. It is not necessary to levy a compensating amount of tax retroactively in order to recover a tax incentive. Yet, the tax authorities must take measures to ensure that the undertaking that received the aid pays a sum that corresponds to the amount of the tax benefit that was unlawfully granted. ${ }^{21}$ In practice, it does not matter whether a corporations pays a formal 'tax' or any other kind of financial contribution to the State instead, when ordered to recover a tax incentive. Nevertheless, should any kind of retroactive payment face a constitutional prohibition, then recovery would be made effectively impossible. In theory, the principle of effectiveness would

ECJ 94/87 of 2 February 1989, Commission v Germany, ECR 1989, 175, paragraphs 9-10; emphasis added by the author. 
require the Member State to set aside even constitutional restrictions to accomplish effective recovery. 22

What the Commission and the ECJ seem after is to leave the Member States free in determining their national procedural framework(s) for recovery. They are left free in choosing the method(s) and procedures they want to use to recover, and it is up to them to appoint the appropriate judicial bodies that have jurisdiction in the matter. But on the other hand, the material aspects of recovery are set by Community standards. ${ }^{23}$ Material law provides that recovery has to take place, unless insurmountable, exceptional circumstances occur or legitimate expectations turn out to be present on the basis of Community standards. ${ }^{24}$ This way the principle of subsidiarity seems best served while maintaining compliance with the material aspects of community law.

\section{Absolute Impossibility to Recover}

\subsection{Exceptional Circumstances}

In theory there may be exceptional circumstances that prevent recovery. It is up to the national courts to determine what these circumstances may be; they may ask the ECJ for a preliminary ruling if needed. One of these circumstances are the legitimate expectations of the recipient of the aid involved. ${ }^{25}$ This will be discussed in

Director General SCHAUB of DG Competition: "When looking at the Procedural regulation and the jurisprudence, there is no doubt anymore that national law must ensure the reimbursement of the aid. The only question left open is when the reimbursement will take place." (Speech at the State Aid Forum, Copenhague, 26 January 2001, emphasis in original.) I would like to add that the question of "how" is to a certain extent also still a question left open to be answered by national law. See chapter VII.3.4.

In non-state aid cases where the ECJ brought the principles of equivalence and effectivity into play, it was concerned with ensuring "the legal protection which individuals derive from the direct effect of Community law. In the absence of Community rules governing a matter, it is for the domestic legal system of each Member State to designate the courts and tribunals having jurisdiction and to lay down the detailed procedural rules governing actions for safeguarding rights which individuals derive from the direct effect of Community law." (EC) 33/76 of 16 December 1976, Rewe-Zentralfinanz and Others v Landwirschaftskammer für das Saarland, ECR 1976, p. 1989; ECJ joined cases C-397/98 and C-410/98 of 8 March 2001, Metallgesellschaft and Others / Hoechst v Commissioners of Inland Revenue and HM Attorney General, ECR 2001, 1-1727, paragraph 85.)

ECJ C-5/89 of 20 September 1990, Commission v Germany, ECR 1990, I-3437, paragraph 16. Prechal rightly concludes that national courts will often be forced to use higher standards when determining the legitimacy of expectations in cases covered by the ECJ's jurisdiction, compared to pure national cases. (S. Prechal, case note to C-5/89, in: AB 1993/143). Also see CFI T-459/93 of 8 June 1995, Siemens v Commission, ECR 1995, II-1675, paragraph 104. 
paragraph 4, infra. In this paragraph we look at some of the other difficulties that may arise in case of recovery; none of them has yet been recognised as an 'exceptional circumstance'.

It should first be considered that the Member State has only an executive task in regard to recovery; it has no discretion itself in deciding whether or not to recover. If the Member State encounters unforeseeable difficulties upon recovery or consequences overlooked by the Commission, it must co-operate with the Commission to overcome them in order to be able to observe the state aid provisions after all. The Member State cannot merely inform the Commission of any legal and political difficulties it expects to face; it must at least try to recover the aid and propose alternatives for implementing the recovery decision correctly. ${ }^{26}$

A Member State that does not carry out a recovery decision cannot claim that the decision itself is unlawful if it did not raise an appeal against the decision itself in time,${ }^{27}$ unless its unlawfulness is obvious. If the ECJ would be asked to declare that a Member State has failed to perform recovery, the latter can only plead that the (uncontested) recovery decision is unlawful, in case that decision contains

"particularly serious and manifest defects such that it could be deemed nonexistent”. 28

\subsection{Financial Difficulties}

The only defence a Member State may bring forward is to claim the absolute impossibility of implementing a recovery decision properly. ${ }^{29}$ In practice, these claims are due to be dismissed. For instance, realistic threats that recovering a tax credit will have severe and hard repercussions on social and economic life within a Member State (like strikes and blockades), cannot be used as an escape from recovery; this kind of intimidation is unacceptable to the Commission and the ECJ. ${ }^{30}$

ECJ 52/84 of 15 january 1986, Commission v Belgium, ECR 1986, pp. 89ff; ECJ 94/87 of 2 February 1989, Commission v Germany, ECR 1989, pp. 175ff., paragraphs 9-10; ECJ C-183/91 of 10 June 1993, Commission v Greece, ECR 1993, I-3131, paragraphs 20-21; ECJ C-349/93 of 23 February 1995, Commission v Italy, ECR 1995, 1-343, paragraphs 13-15; ECJ C-280/95 of 29 January 1998, Commission v Italy, ECR 1998, I-259, paragraph 16; ECJ C-6/97 of 19 May 1999, Italy v Commission, ECR 1999, I-2981, paragraph 34; ECJ C404/97 of 27 June 2000, Commission v Portugal, ECR 2000, 1-4897, paragraph 52.

ECJ C-404/97 of 27 June 2000, Commission v Portugal, ECR 2000, 1-4897, paragraph 34-36; ECJ C-261/99 of 22 March 2001, Commission v France, ECR 2001, 1-2537, paragraph 18-20. The non-compliance procedure is set forth in Articles 226 EC (initiation by the Commission) and 227 EC (initiation by a fellow Member State). 
Recovery is not made impossible by the mere fact that a company encounters financial difficulties. ${ }^{31}$ Potential bankruptcy cannot block recovery either. The presence of capital that is intangible for the time being cannot prevent recovery, since liquidating the company would still be a possibility to make the necessary funds available.32 If necessary, the appropriate (tax) authorities should initiate insolvency proceedings and have a company wound up in order to enforce the recovery claim against any recoverable assets (if permitted by the ranking of their claim). In the absence of such liquidation the authorities will not be in a position to show that there are no recoverable assets in the absence of which recovery might be considered impossible. ${ }^{33}$

Arguing that recovery is impossible because the gain no longer exists and bad faith was absent on the part of the recipient will also be unsuccessful. When it comes to firms in financial difficulty, the added value resulting from the aid will in most cases no longer be revealed on the balance sheet even though it has been indisputably present according to the ECJ. ${ }^{34}$ The Member State's own (potential) financial 'difficulties' as a result of incurring liability cannot stand in the way of recovery either. ${ }^{35}$

\subsection{Administrative Difficulties}

As for direct taxes, it is unlikely that administrative difficulties will be so severe that recovery is (technically) impossible. Corporate and income tax assessment should be properly registered, so that it would be possible to determine whether a taxpayer was granted a certain recoverable tax incentive. Even though calculating the net incentive may be very difficult - depending on the character of the aid, the structure of the national tax system and the relation between the taxable amount and certain deductions - it seems that doing so cannot be deemed absolutely impossible with the electronic means available in the 21st century. ${ }^{36}$ Although these difficult calculations still have to be prepared and supervised by human beings, a shortage in the staff capacity of the tax authorities nor the costs involved can be regarded as an excuse not to recover. ${ }^{37}$ As Advocate General FENNELLY recalls,

ECJ 63/87 of 7 June 1988, Commission v Greece, ECR 1988, 2875.

ECJ 52/84 of 15 January 1986, Commission v Belgium, ECR 1986, p. 89, paragraph 14.

Also see ECJ C-499/99 of 2 July 2002, Commission v Spain, not yet published, paragraphs 37-39.

ECJ C-24/95 of 20 March 1997, Land Rheinland-Pfalz v Alcan Deutschland, ECR 1997, 1-1591. It must be added that - together with recovery - the granting of other aid might be approved in order to rescue a company. See Council Regulation EC 659/1999, OJ L 83/1 of 27 March 1999, Article 11(2).

ECJ C-404/97 of 27 June 2000, Commission v Portugal, ECR 2000, 1-4897, paragraph 53.

See ECJ C-378/98 of 3 July 2001, Commission v Belgium (Maribel bis/ter), ECR 2001, 1-5107.

For instance ECJ C-280/95 of 29 January 1998, Commission v Italy, ECR 1998, 1-259, paragraphs 18-25. 


\begin{abstract}
"the concept of absolute impossibility does not permit any assessment of the proportionality of ends and means in terminating an unlawful distortion of competitive conditions, except, possibly, in the most extreme circumstances." 38
\end{abstract}

Such circumstances have not yet come forward in the ECJ's jurisprudence. Notwithstanding the above, the indirect granting of tax incentives may give rise for concern. In order to be able to recover any aid, the Member State must first determine the recoverable amount provided that the Commission did not do so already. In regard to determining the (net) amount of a tax benefit, the national government is often better suited to apply the different provisions of national tax law that are often closely related. In most cases it will be possible to get at least an estimate of the amount of aid that is to be recovered from the enterprise. Only in few occasions, the recoverable amount is not as evident.

Suppose private investors receive a reduction of taxes on interests received on loans to certain industrial funds or a special tax deduction for losses on such loans. As a result thereof those funds will be able to provide loans to qualifying enterprises at more favourable conditions while maintaining an after-tax return on investment for the private investors that would be similar to that of other loans that do not qualify for the special tax treatment. Normally, a qualifying enterprise would either have to take out loans at a higher interest rate or it even may not be able to attract loans at all. ${ }^{39}$ The same could also apply on loans that are directly provided to certain enterprises (such as film producing companies).

The benefit at the side of the private investor can easily be determined on the basis of the tax declarations on file; quantifying the (indirect) benefit that the enterprise got will be harder. ${ }^{40}$ It is still open for debate whether the private investor should be asked for repayment of his tax benefit in order to accomplish recovery. If the investor has no legal basis to claim compensation from the fund or enterprise to which he lend his money, then the purpose of recovery - taking away the enterprise's unlawful (indirect) benefit - cannot be accomplished. ${ }^{41}$ Even though the investor may be able to retrieve his money instantly by cancelling the loan (if possible), the benefit that was received in the meantime stays intact. In such cases recovery will have to take place by using non-fiscal means to effectively undo the

Opinion in case C-6/97 of 26 June 1997, Commission v Italy, ECR 1998, I-259, paragraph 21.

39 See chapter II.1.3.3 on the issue of indirect benefits.

40 Recovery normally requires the exact determination of the amount of aid received, though I am of opinion that the courts and the commission will settle for prudent estimates in the last resort (subject to court review).

Moreover, there seems to be no basis for recovery from individuals (not being entrepreneurs), since tax breaks for individuals fall outside the scope of the state aid regime as such. Only if there would be (full) compensation for the private investor from the enterprise, performing recovery through the intermediary could be considered an option. 
benefit of the actual beneficiary, instead of taking futile action against the intermediary. ${ }^{42}$ It would thus be up to the Member State to determine the means that are suited for the purpose of recovering an aid from the actual beneficiary.

\subsection{National Court Order}

A national court order not to recover will make recovery impossible in my opinion, since the Community cannot expect the Member State to set aside a decision made by its judiciary. A national court may be called upon to determine the exact amount of aid that is to be recovered, if the Commission left this to the Member States to determine. This is of special interest in fiscal cases where determining the amount of fiscal benefit may require detailed knowledge of the national fiscal system at issue. On the other hand, a national court may not prohibit recovery since the decision by the Commission to recover is binding to the recipient if he failed to start annulment proceedings in time. ${ }^{43}$ When deciding on recovery issues, the national courts must take the interests of the Community fully into consideration. ${ }^{44}$

Should a national court nevertheless prohibit recovery in its entirety, I do not see how the Member State should be able to set aside such decision. Since the Member State is obliged to take any legal action in its power, it will have to file an appeal against any decision not to recover from a lower court as to perform its duties to the Community properly. ${ }^{45}$ But in case a Supreme Court or a constitutional court upholds the non-recovery order, then things are much more difficult. Of course such courts should ask prejudicial questions to the ECJ in case the matter is not evident from the European legal perspective, but nevertheless once the national courts give a final ruling - regardless of its compatibility with EC Law - the Member State's hands are tied. Be that as it may, the Member State bears the (financial) responsibility for the actions of its courts when faced with infringement proceedings at the ECJ.

Recovery should take place from the actual beneficiary. See the Commission's decision in the Dutch Gasoline Stations case, OJ L 280/87 of 30 October 1999 as affirmed by ECJ C-382/99 of 13 June 2002, The Netherlands v Commission, not yet published, paragraph 92.

The recipient cannot challenge the recovery decision as part of national court proceedings anymore, because this would extend the time limit set for such action. ECJ C-188/92 of 9 March 1994, Textilwerke Deggendorf GmbH (TWD 1) v Germany, ECR 1994, I-833. A Member State may neither question the validity of a decision after expiration of the time limit, thus ECR 156/77 of 12 October 1978, Commission v Belgium, ECR 1978, 1881 and C-183/91, Commission v Greece, ECR 1993, 1-3131.

This will especially be the case when a lower court protects legitimate expectations that are evident on the basis of national standards but not on the basis of community standards. When even the highest court fails to use the proper standards, the Member State may face fines for a misjudgement made by its courts if the Community institutions would try to enforce recovery. I hold the latter to be a mere theoretical possibility. 
The chance that a national court will actually prohibit recovery is near nil. The 1999 report on 'Application of EC state aid law by the Member State courts' showed that there had been no (recent) cases in the various national courts in which beneficiaries successfully resisted recovery relying on principles of national law. This led the co-ordinators of the report to the conclusion that this "no longer appears to be an area of concern" ${ }^{46}$ Nevertheless, there are certain principles that are not only a part of national law but also of Community law, such as the protection of legitimate expectations. This could still stand a chance in resisting recovery, at least in theory.

\section{Legitimate Expectations of the Recipient}

\subsection{The ECJ's Perspective}

The issue whether a recipient could block recovery because he maintains legitimate expectations as to the absence or compatibility of state aid, should be placed in its proper context. The principles of protection of legitimate expectations and legal certainty are an integral part of the Community's legal order. ${ }^{47}$ Their application in the field of recovery of state aids is a very sensitive subject. It is even more sensitive in the field of recovery of tax incentives where there is still a sense of fiscal sovereignty. However, there is no special treatment for tax incentives since ordering recovery cannot depend on the form in which aid was granted, ${ }^{48}$ whether as a direct tax measure, a cash grant or otherwise. Whether legitimate expectations can stand in the way of recovery is best illustrated by looking into the jurisprudence of the EC Courts. In 1983 the ECJ ruled:

"Community law does not prevent national law from having regard, in excluding the recovery of unduly-paid aids, to such considerations as the protection of legitimate expectation, the loss of unjustified enrichment, the passing of a time-limit or the fact that the administration knew, or was unaware owing to gross negligence on its part, that it was wrong in granting the aids in question, provided however that the conditions laid down are the same as for the

Jestaedt / OtTERVANGer / VAN CUTSEM (1999), p. 241.

ECJ 205-215/82 of 21 September 1983, Deutsche Milchkontor and Others v Germany, ECR 1987, 2633, paragraph 30. Also see ECJ 265/85 of 11 March 1987, Van den Berg en Jurgens BV and Others v Commission, ECR 1987, p. 1155, paragraph 14.

ECJ C-404/97 of 27 June 2000, Commission v Portugal, ECR 2000, I-4897, paragraph 39; ECJ C-183/91 of 10 June 1993, Commission v Greece, ECR 1993, I-3131, paragraph 16. 
recovery of purely national financial benefits and the interests of the community are taken fully into account." 49

\title{
The ECJ came up with a more restrictive interpretation in 1990:
}

\begin{abstract}
"In principle the recovery of aid unlawfully paid must take place in accordance with the relevant procedural provisions of national law, subject however to the proviso that those provisions are to be applied in such a way that the recovery required by Community Law is not rendered practically impossible $[\ldots], .50$
\end{abstract}

In the 1997 Alcan judgement the ECJ ruled that recovery should even take place if the competent national authority is responsible for the unlawfulness of an aid to such a degree that recovery would appear to be a breach of good faith toward the recipient, when proper state aid procedure had not been followed. ${ }^{51}$ HOENIKE concludes that in regard to Alcan the incorrect and unlawful behaviour of the authorities was attributed to the beneficiary. ${ }^{52}$ The fact that proper procedures had not been followed was decisive in that case. It was considered irrelevant that the national authorities had allowed the national time limit laid down for recovery in

ECJ Joined cases 205-215/82 of 21 September 1983, Deutsch Milchkontor and Others v Germany, ECR 1983, p. 2633, dictum, paragraph 3. ECJ C-142/87 of 21 March 1990, Belgium v Commission, ECR 1990, I-959, paragraph 61. ECR 20 March 1997, C-24/95, Land Rheinland-Pfalz v Alcan Deutschland GmbH, ECR 1997, I-1591. The German constitutional court (the 'Bundesverfassungsgericht') decided in a preliminary ruling in regard to the Alcan case that the ECJ's judgement as applied by the Bundesverwaltungsgericht did not bring the undeniable protection of constitutional rights into question, therefore the constitutional complaint was not to be decided upon. The decision to recover did not violate the principles of legal certainty and protection of legitimate expectations as set forth in the German Constitution. The Bundesverwaltungsgericht did establish that Alcan was in a position to recognise the unlawfulness of the aid. In deciding upon carrying through recovery it did not subordinate Alcan's interests to those of the Member State and the Community in a manner contrary to the Constitution. This does not exclude that under certain conditions it would be possible that the interest of the beneficiary may not be put in a subordinate position, because the Bundesverwaltungsgericht did not deny the application of the German legal provisions on protection of legitimate expectations. (BVerfG of 17 February 2000, BvR 1210/98; BverwG of 17 February 1993, BverwGE 92, 81) In order to place this judgement in the proper perspective DE WEERTH (2001, p. 160) emphasises that the violation concerned a subsidy to only one corporation active on the international market in a sensitive sector. This should have served as an indication for a potential state aid conflict. I would further like to add that Alcan is said to have refused the aid at first and was planning on shutting down, but the local government insisted on granting the aid to keep it running. 
the interest of legal certainty to elapse. It was neither relevant that national law excluded recovery because a gain no longer exists, in the absence of bad faith on the part of the recipient of the aid. According to the ECJ, the latter is in fact the rule in case of state aid, since it is generally granted to undertakings in difficulty, whose balance sheet no longer reveals the added value resulting from an aid the time of recovery.

In its Alcan judgement, the ECJ gave a clear indication in regard to provisions in national law that serve to protect certain principles of law:

\begin{abstract}
"although the Community legal order cannot preclude national legislation which provides that the principles of the protection of legitimate expectations and legal certainty are to be observed with regard to recovery, it must be noted that, in view of the mandatory nature of the supervision of State aid by the Commission under Article [88 EC], undertakings to which aid has been granted may not, in principle, entertain a legitimate expectation that the aid is lawful unless it has been granted in compliance with the procedure laid down in that article. A diligent businessman should normally be able to determine whether that procedure has been followed."53
\end{abstract}

It should be taken into consideration that a beneficiary is under no legal obligation to check whether the aid he receives has been granted in line with state aid procedure. Procedure does not require any interference from the beneficiary in order for aid to be compatible. ${ }^{54}$ Thus a beneficiary that remains passive when receiving aid would do nothing wrong if the State itself had done its job properly. However, not checking procedure will be detrimental to the legitimacy of the beneficiary's expectations in case the aid received in violation of the standstill provision turns out to be incompatible and recovery is ordered. Thus even without any statutory obligation to check upon procedure, I would strongly recommend any beneficiary to do so.

The assumption that a diligent businessman should be able to determine whether the notification and standstill procedure was followed was already established by the ECJ in its 1990 Bug-Alutechnik judgement. ${ }^{55}$ In a fiscal case, the CFI rephrases the status quo as follows:

ECJ C-24/95 of 20 March 1997, Land Rheinland-Pfalz v Alcan Deutschland, ECR 1997, I-1591, paragraph 25 , in reference to C-5/89 of 20 September, Commission v Germany, ECR 1990, I-3437, paragraph 13-14 and C-169/95 of 14 January 1997, Spain v Commission, ECR 1997, 1-135, paragraph 51. aid in the end. My objections to this approach in regard to compensatory interest payments have been set out in paragraph 1, supra. 
"... recipients of unlawful aid are not to be precluded from relying on exceptional circumstances on the basis of which they had legitimately assumed the aid to be lawful. In such cases, legitimate expectations on the part of the recipient will be recognised only if the aid has been granted in compliance with the procedure laid down in Article [88] of the Treaty." 56

However, Advocate General Cosmas considered that this part of the CFI's judgement contained an error. He considered that there is not an irrebuttable presumption that a failure to notify a state aid is sufficient to preclude legitimate expectations, referring to the ECJ's aforementioned Alcan judgement. ${ }^{57}$ Although I cannot but agree with COSMAS on this technicality, the CFI's judgement illustrates the de facto narrowness of the (unidentified) leeway provided by the ECJ very well. ${ }^{58}$

The Member State itself may not rely on the expectations of recipients when it comes to implementing a recovery decision, ${ }^{59}$ nor may it rely on the principle of protection of legitimate expectations to justify a failure to recover ${ }^{60}$ If it could, its own unlawful conduct would become an excuse not to recover. ${ }^{61}$ It is therefore up to the beneficiary to bring this argument to the attention of the Commission and the Courts. ${ }^{62}$

CFI T-67/94 of 27 January 1998, Ladbroke Racing v Commission, ECR 1998, II-1, paragraph 182. Emphasis added by the author.

Opinion of 23 November 1999, paragraphs 96-97, concerning ECJ C-83/98P, France v Ladbroke Racing and Commission, ECR 2000, I-3271. The ECJ itself did not find it necessary to go into the details of this issue since it considered the CFI's conclusion to annul the Commission's decision to be correct (paragraph 59).

The CFI recently repeated that legitimate expectations can be recognised only in case proper procedure has been followed. (Joined cases T-92/00 and T-103/00 of 6 March 2002, Territorio Histórico de Álava and Others v Commission (Ramondín), Dutch version, not yet published, paragraph 54.) However, on the same day the CFI (in the same compilation) rendered a judgement that legitimate expectations in principle require proper procedure to be followed, in conformity with the ECJ's jurisprudence. Joined cases T127/99, T-129/99 and T-148/99 of 6 March 2002, Territorio Histórico de Álava and Others v Commission, Dutch version, not yet published, paragraph 236.) In the latter judgement the CFI emphasised that regional authorities should be considered able to check whether proper procedure was followed, just like a diligent businessman.

ECJ C-5/89 of 20 September 1990, Commission v Germany, ECR 1990, 1-3437, paragraph 17.

ECJ Joined Cases C-278/92, C-279/92 and C-280/92 of 14 September 1994, Spain v Commission, ECR 1994, I-4103, paragraph 76

CFI T-67/94 of 27 January 1998, Ladbroke Racing v Commission, ECR 1998, II-1, paragraph 181.

The CFI ruled that it is not sufficient for the Commission to rely on the position adopted by the Member State in regard to legitimate expectations recipients allegedly entertained when deciding to limit the temporal scope of an obligation to recover. Because the CFI's decision to annul the Commission's decision was 


\subsection{Restrictive Interpretation of Legitimacy}

Recovery is an essential safeguard for the proper functioning of the Common Market that is at the basis of the European Community. It its jurisprudence, the ECJ emphasises the importance of actual recovery of unlawful aids frequently. VAN WIJK ET AL. express the most likely explanation for the ECJ's rigid position in regard to state aid and legitimate expectations: most of the individuals that European Institutions have to deal with are large corporations that have a lot of expertise. Contra legem application could lead to a disparity in the application of Community Law in the different Member States and it could open the door for a policy that intentionally violates Community Law. ${ }^{63}$

The reluctance to acknowledge legitimate expectations is essentialy based on a presumed co-operative relationship between the government and the beneficiary in matters of state aid. Member States could deliberately grant subsidies and fiscal incentives that are to be regarded as state aid without notifying them, in order to assist certain enterprises anyhow. Even though this is inconceivable in a perfect world - where Member States take every action necessary to comply with their obligations toward the Community - it can still be reality nowadays.

It seems to me that the concept of an intentional contra legem policy where administrations and beneficiaries may conspire as a matter of national interest even though it is nothing more than a mere possibility - explains why the ECJ is so reticent to make room for legitimate expectations. Except for convincing evidence to the contrary, it must be assumed that enterprises are of bad faith when accepting state aid in order to rule out any deliberate abuse of the limited room for legitimate expectations. In general, Member State actions contra the European Lex (like granting incompatible aid) are not to be tolerated in order to prevent the undermining of its uniform application within the Community. ${ }^{64}$

If we want to make sure that every beneficiary is aware of the existence of state aid provisions, I recommend that governments and tax authorities should at least print an explicit reservation on any document granting a subsidy, including tax assessments. It should be stated that (fiscal) aids might be subject to approval of the Commission under EC State Aid rules. Such reservation could even provide a reference to further information, such as official documents and legal provisions.

considered to be correct as such, the ECJ did not find it necessary to confirm the CFI's ruling on this specific matter. (CFI T-67/94 of 27 January 1998, Ladbroke Racing Ltd. v Commission, ECR 1998, II-1, paragraphs 183-185; ECJ C-83/98P, France v Ladbroke Racing and Commission, ECR 2000, I-3271.) In this case the Commission only required recovery as from the date the formal procedure was opened. See also VAN DER BURG (1998), p. 76; WIDDERSHOVEN (1994), p. 3; JANS ET AL. (1999), p. 206. 


\subsection{The Commission's Actions: Foreseeability, Expediency and Time Limits}

Acts from the Commission as an institution are the most likely basis for successfully relying on legitimate expectations ${ }^{65}$ Guidelines published by the Commission may rise certain expectations if a beneficiary would check his aid with these guidelines, but only when all conditions mentioned therein are actually fulfilled. This will play an important role in making the de minimis exemption treaty-proof. In chapter II.3.2.1, I discussed the fact that the present regulation on de minimis aid may not be in compliance with the EC Treaty. The exemption of such aids from the scope of the state aid definition in its present form contains an error in law and is not in line with the concept of state aid as defined in the Treaty. In this respect we should consider that its guidelines and regulations bind the Commission, but their legitimacy may be questioned in court. ${ }^{66}$ Should the ECJ set the present regulatory framework for de minimis aids aside when called upon to do so, then the beneficiaries can relatively safely rely on the expectations raised consistently by the Commission and the Council concerning the alleged compatibility of such aids.

Important sources for legitimate expectations are the prior decisions taken by the Commission stating the absence of aid or the compatibility of aid. ${ }^{67}$ We must however consider that when an existing aid is altered one may not presume that it will be regarded compatible again. The obligation to notify (non-marginal) changes in an existing aid scheme forces the Commission to re-evaluate the aid and to render a new decision. On the other hand, the Commission must offer a transitional measure when it decides to reclassify an existing aid as incompatible, provided that this could not have been foreseen. The examples of Ireland and Spain hereafter will illustrate this:

An informal confirmation by a Commission official that an aid will be regarded compatible or not to be state aid, cannot give rise to legitimate expectations, since no Community official can give authorisation to leave Community Law inapplicable. (ECJ 188/82 of 16 November 1983, Thyssen AG v Commission, ECR 1983, pp. 3721ff.)

CFI T-149/95 of 5 November 1997, Ducros v Commission, ECR 1997, II-2031.

In a French case concerning a tax exemption granted to certain sectors of industry for setting up branches abroad, the Commission confirmed that, since it had decided that the tax exemption did not comprise state aid twice in the past, the principle of protection of legitimate expectations could be invoked. It therefore did not order the recovery of the aid involved granted prior to the day the final decision on incompatibility was taken. Press release IP/01/1627 of 21 November 2001. The Commission's third ruling concerned a matter of compatibility with the ECSC Treaty, which contains a state aid definition that is similar in part to that of the EC Treaty. The ECSC regime is stricter since it contains an absolute prohibition of aid to the coal and/or steel sector without the need to proof the effect of the aid on intra-community competition or trade. See Article 4(c) of the ECSC and Hancher et al. (1999), pp. 186-198. The ECSC Treaty is due to expire on 23 July 2002. 
In regard to an Irish special corporation tax rate scheme of $10 \%$ for the manufacturing sector, the Commission ruled in 1980 that such rate did not constitute aid. The Irish government guaranteed that this regime would apply until 31 December 2010. After a re-examination of the scheme in 1998, the Commission came to the conclusion that the scheme did constitute (operating) aid. In regard to two other Irish tax rate schemes, consisting of an extension of the special rate to certain approved trading operations and services in specific areas, the Commission considered these to be state aids. It approved these schemes in 1987 and several continuations thereof, most recent in 1994. At the time, the entire territory of Ireland was considered to be an $87(3)$ (a) region, which provided the basis for the approval of the special tax rate schemes. The approval of the two latter schemes was limited in time till 2005. However, in 1998 the Commission came to the conclusion that the eligibility of the territory as a whole should come to an end as of 2000. It further noted that

\footnotetext{
"the Irish authorities have not demonstrated the existence or importance of regional handicaps affecting the sectors concerned (in particular, the financial sector) which the [...] schemes seek to alleviate".
}

The Commission subsequently considered all three schemes to be incompatible with the common market and recommended their elimination. However, given the fact that the Commission had so far regarded the first scheme to be a general measure, and authorised the two latter schemes,

"the Commission accepts that beneficiaries could not have reasonably foreseen that the Commission would find them incompatible and ask for them to be abolished." 68

The Commission therefore allowed certain projects eligible for the tax schemes prior to 31 May 1998 (the cut-off day for the approval of

Proposal for appropriate measures concerning the Irish corporation Tax, OJ C 395/19 of 18 December 1998, paragraph 3; proposal for appropriate measures concerning the International Financial Service Centre and Shannon customs-free airport zone, OJ C 395/14 of 18 December 1998, paragraph 3; both in reference to ECJ 265/85 of 11 March 1987, Van den Berg en Jurgens BV and Others v Commission, ECR 1987, p. 1155, paragraph 14. (Italics added by the author.) The Commission explicitly considered that the Irish Government provided "the maximum possible guarantee as regards the stability and predictability of their tax system. In this spirit, they have consciously set out to create expectations amongst eligible businesses as regard their uninterrupted eligibility for the $10 \%$ corporation tax up to 31 December 1995." 
projects eligible for the full life of the schemes) to retain their eligibility for the special tax schemes until the end of 2010 or 2005 respectively. ${ }^{69}$

Another example concerns the Biscayan coordination centre regime. The Commission determined that a Belgian coordination centre regime did not constitute aid back in 1984. The Spanish province of Biscaye introduced a similar regime believing that it did not constitute aid either. In 2002 the Commission opened a formal investigation into the existing Belgian regime, because it believed that this regime now constitutes state aid. As I addressed in chapter III.1, I have doubts about this change in mind. Be that as it may, the Commission decided not to order the recovery of the Biscaye tax benefit, because its previous decision on Belgium gave rise to legitimate expectations at the part of Biscaye concering the absence of state aid at the time of implementation taking account of the similarities of both regimes. ${ }^{70}$

Normally the time needed for a decision cannot in itself create legitimate expectations; as a rule only exact and unequivocal promises from the Commission can do so. Yet, legitimate expectations were regarded present in the RSV-case, where the Commission needed 26 months to take a decision. ${ }^{71}$ In that case the beneficiary had already received approved aid for its shipbuilding and offshore engineering operations and new aid was to be granted to cover additional costs of those operations. The ECJ therefore annulled the Commission's recovery decision. The special circumstances that called for such approach in this case were (1) the notification of the aid, (2) the fact that the government supplied the necessary information in time and (3) the lack of need for deep research. ${ }^{72}$

In the SFEI case several competitors complained that an unnotified aid was not to be recovered because it was considered to be existing aid because of the long duration of the Commission's proceedings. The ECJ explicitly held that

Other transitional provisions also applied in order to "ensure an orderly phasing out" of the schemes.

These included an extended period for the approval of new schemes until 31 December 2002 under the first scheme, or 31 December 1999 under the two latter regimes. Projects approved after 31 May 1998 could only be eligible for the special tax rate schemes until 31 December 2002.

70

Commission press release IP/02/1236 of 26 August 2002 (Biscaye coordination centre regime).

ECJ 223/85 of 24 November 1987, Rijn-Schelde-Verolme Machinefabrieken en Scheepswerven NV (RSV) v Commission, ECR 1987, 4617.

See CFI T-55/99 of 29 September 2000, Confederación Española de Transporte de Mercancias v Commission, ECR 2000, II-3207, paragraphs 147-152. 
"it cannot be accepted that the Commission's delay in completing its preliminary examination may result in the transformation of new aid granted in breach of the last sentence of Article [87(3) EC] into existing aid which can be abolished only with respect to the future."73

In the Piagio case the ECJ confirmed this view:

\begin{abstract}
"The Commission has, however, classified the system under Law No 95/79 as an 'existing State aid', whilst recognising that that Law, although promulgated after the entry into force of the Treaty, was not notified to it in accordance with the provisions of Article 88(3) EC. Its position is based on reasons of practical expediency, including, in particular, its own doubts, which extended over 14 years, concerning the classification of Law No 95/79 as State aid, the expectations of traders subject to that system, the infrequent application of the system, and the impossibility in practice of obtaining repayment of the sums which might be recoverable. That position cannot be accepted."74
\end{abstract}

Even though the ECJ merely ruled that the Commission could not let unnotified aid become existing aid without following proper procedure, this also indicates that the Commission could not get around the issue of recovery so easily by deeming an aid to be existing aid. Nevertheless, in its follow-up decision the Commission recalled that it fostered the legitimate expectations of parties that it would treat the aid as existing aid. It decided that it had 'no ground for requiring Italy to recover', 75 because the aid that was already granted for 20 years prior to the initiation of an investigation and its attitude in this matter raised certain expectations at the Member State and the 500 recipients. ${ }^{76}$ The latter decision has not been subjected to review by Community Courts. I have certain reservations about using this approach in future cases, because the mere passing by of time seems not sufficient to give rise to legitimate expectations as far as it concerns the presence of 'existing' aid.

In this respect the CFI most recently held that a determination of whether there is existing aid should take place

"without reference to the time which has elapsed since the measure in question was introduced and independently of any previous administrative practice."

It however indicates that 
"any uncertainty which may have existed in that regard may at most be regarded as having given rise to a legitimate expectation on the part of the recipients so as to prevent recovery of the aid paid in the past." 77

The latter indicates that the CFI leaves room for the elapsing of time to still stand in the way of recovery without assuming the presence of existing aid. I assume that it will be rather reluctant to make such finding, except in those rare cases like the aforementioned $R S V$-case where special circumstances would justify non-recovery.

Since the Commission is nowadays obliged to require recovery, unless a principle of community law stands in its way, it should be very careful with nonrecovery. It should provide compelling reasons that made it decide not to recover rather than the other way around. ${ }^{78}$

In a decision regarding some Spanish tax credits the Commission also decided not to recover. The Commission was alerted by competitors of the potential aid in April 1996. It opened the formal procedure in August 1997 and took its final decision in October 2000. The investigation took a lot of time, without Spain being in any way responsible for the delay. Furthermore, the Spanish measures resembled a French tax measure that was not regarded to be aid. Also, the Member of the Commission responsible for competition responded to a question from a Member of the European Parliament stating that the Spanish measure had been notified upon accession of Spain to the Community in its previous form as part of a 1978 Law and had not raised any objection. Under these circumstance, the time delay together with the similarity with the French regime and the statement of the Commission Member lead to Commission to concluded that 'even the most cautious and well informed' beneficiaries could not have foreseen that the measure would be classified as state aid. Therefore, it was appropriate not to recover in the view of the Commission. ${ }^{79}$

The Commission was far more lenient in an Italian case back in 1990. The initial procedure against a non-notified aid granted in 1986 and 129 ; italics added by the author.

The Commission should clearly motivate a decision not to levy interest as from the day incompatible aid was granted, thus ECJ C-83/98P of 16 May 2000, France v Ladbroke Racing and Commission, ECR 2000, I3271, paragraphs 55-61. In this case the Commission took into consideration that the French Conseil d'État gave rise to certain legitimate expectations in the compatibility of the aid in question, without elaborating on the issue why a judgement of the Conseil d'État would have such effect. 
was started at the end of 1987. The formal procedure started one year later in November 1988. The final decision was taken in July 1990. The long interval between the time the Commission got knowledge of the aid and the taking of the decision made the Commission decide not to recover. ${ }^{80}$

It is to be awaited whether the Commission would have acted similarly if this unnotified aid case would have been processed under the new Procedural Regulation. This Regulation explicitly states that there is no formal time limit to the length of the procedure in cases of unlawfully granted aid. ${ }^{81}$ But even in the absence of such limit, the Commission is not fully free to extent procedure indefinitely. The length of procedure must still be reasonable in regard of the circumstances of the individual case. The two and a half years in the above case would indeed deserve some kind of justification, but under the new procedural regulation one cannot be certain whether this time delay justifies a decision not to recover. However, the oneyear length of the preliminary investigation makes one wonder why the Commission did not open the formal procedure sooner, because it seemed obvious that the case was not evident on the basis of preliminary research.

\subsection{Risk of Annulment of a Favourable Decision}

Can a Member State and a beneficiary act upon a positive decision of the Commission without facing any consequences when such decision is challenged by a third party and subsequently annulled? Such decision could be regarded as a foreseeable event, since it is a normal part of Community procedure. SINNAEVE therefore proposed to formally extend the standstill period with a risk period during which the beneficiary may take the risk to accept aid granted upon approval that may still be or become subject to an annulment procedure. ${ }^{82}$ On the other hand, the EC courts have the authority to suspend the application of a contested positive Commission decision if necessary. ${ }^{83}$ If these courts recognise the potential damage to injured parties resulting from aid that is going to be granted, they might decide to suspend a positive decision - and thus to uphold a standstill - until annulment proceedings are over or prospectless. The present procedural regulation does not give guidance on whether the standstill clause revives from the date of annulment by a Community Court or from the date the Commission decision was taken. ${ }^{84}$

81 There is a time limit in cases of provisional recovery, thus Article 13(2) of Regulation 169/1999. Also recall the 10-year term of limitation on giving an order to recover, as set forth in Article 15(1) of said Regulation. 
In case the Commission decides to let a Member State know that it does not to object to an unnotified aid brought to its attention, the situation upon annulment is clearer. According to the ECJ,

"[the] fact that the Commission initially decided not to raise any objections to the aid in issue cannot be regarded as capable of having caused the recipient undertaking to entertain any legitimate expectation since that decision was challenged in due time before the Court, which annulled it. However regrettable it may be, the Commission's error cannot erase the consequences of the unlawful conduct $[\ldots] . " 85$

\section{Recovery as a Fine}

Is it necessary to enforce the state aid notification and standstill procedure by creating a basis for fines? At present, a Member State that fully complies with an order to recover in due time may suffer limited financial consequences. The amount recovered will become part of the Member State's funds again. It may be considered not to let the beneficiary be the only one to bear substantial financial risks in regard to recovery. An (additional) disincentive could be introduced for the Member State, like the threat of fines as a measure to prevent the granting of unlawful aids. I would like to point out from the outset that introducing a system of fines does not affect the obligation to recover unlawful aids from the beneficiary. The obligation to recover and thus the financial risk borne by the beneficiary would remain fully intact.

SIMPLICEAN-STROIA proposes several options in order to stimulate the compliance of Member States with the notification and stand-still requirements of article 88(3) EC, two of which will be discussed hereafter ${ }^{86}$ First, she proposes imposing fines on Member States upon infringement, which should be proportional to the amount of unlawfully granted aid and the gravity of the infringement (especially taking account of recurring infringements). These fines should be combined with periodic payments till such time that a Commission decision is complied with. ${ }^{87}$ Alternatively, she proposes that the Commission should confiscate unlawful aids itself instead of ordering the Member State to do so. ${ }^{88}$ The confiscated amount will not flow back into the Member States public funds. It will rather be available to the Community. Parties that have been harmed by the unlawful aid could then apply for compensation out of the Community funds to the extent of the amount recovered. In those cases where confiscation is not possible, the Member 
State should be required to pay the non-confiscated amount to the Community funds.

In regard to the first option, it should be considered that fines require a firm legal basis that is not explicitly nor implicitly provided for in the EC Treaty. The ECJ held that

"a penalty, even of a non criminal nature, cannot be imposed unless it rests on a clear and unambiguous legal basis" ${ }^{89}$

As to recovery itself, its intention is to restore a previously legal situation by taking away the benefit of the aid that the beneficiary unlawfully enjoyed. This cannot be regarded a sanction, according to the ECJ. ${ }^{90}$ The imposition of sanctions in case of non-recovery is another matter. At present, only the ECJ can impose a lump sum or penalty payment. If the ECJ finds that a Member State failed to fulfil its obligation to recover, that State will be required to take the measures necessary to fulfil its obligations within a time limit provided by the Commission. If it fails to do so, the Commission may bring the matter before the ECJ a second time, specifying the lump sum or penalty payment that it considers appropriate. ${ }^{91}$ If the ECJ confirms the Commission's view, it may impose such sum or payment. Should the Member State have complied with the first judgement, there would not have been a basis to do so,

Creating a legal basis for a fine upon violation of Article 88(3) EC could be more effective, since it would have a preventive effect signalling Member States not to try and gamble. At least there would be a real financial disincentive that is lacking in the present situation where the Member State may keep the recovered amount.

The second option can neither be realised under the present Treaty. Article 88 (2) EC only provides a basis for the Commission to order a State to abolish or alter an aid (the implicit basis for recovery). Even though confiscation would be the most effective way of recovery, the political aversion to creating a legal basis will be enormous. Especially in regard to tax revenue, confiscation will probably be felt as the ultimate infraction on a State's fiscal sovereignty. Another problem is that the

ECJ C-172/89 of 12 December 1990, Vandemoortele NV v Commission, ECR 1990, 1-4677, paragraph 9; ECJ 117/83 of 15 September 1984, Konecke v Balm, ECR 1984, p. 3291.

Article $228 \mathrm{EC}$ in reference to articles 226 and $227 \mathrm{EC}$. Before bringing the matter before the ECJ a second time, the Commission must issue a reasoned opinion specifying the points on which the Member State did not comply with the ECJ's judgement. The Member State must be granted the opportunity to submit its reservations before issuing the opinion. DG Competition has not had appropriate cases to use Article 228 EC until now, but its Director General SCHAuB stated that the Commission 'will not hesitate' to refer the matter to the ECI a second time applying for penalty payments if and when such cases would occur. (Speech at the State Aid Forum, Copenhague, 26 January 2001.) 
Commission will be too short-staffed to pursue confiscation in all cases. Without a uniform confiscation procedure across the EC on the basis of an Article 89 EC regulation, gathering the necessary expertise in order to confiscate in each of the Member States will be a stiff job and rather unrealistic. Therefore, should fining become politically viable, then I am in favour of the first option.

\section{Demanding Notification}

Suppose a potential beneficiary acts like a diligent businessman and checks whether proper procedure was followed. He may end up in a deadlock should he determine that these procedures have not been followed correctly. What should he do if he suspects that he is about to receive aid in violation of the notification and standstill obligation? Of course, the beneficiary may ask the granting authority to notify the measure if it not already did. That same authority may have its reasons not to, except when notification was overlooked accidentally. It may be of opinion that a certain measure does not qualify as state aid and is therefore not to be notified. Alternatively, it may argue that the measure is not to be notified in case of existing aid or an applicable general exemption like de minimis. If the beneficiary is only one out of thousands, its objection will not result in the desired notification. One cannot expect that the beneficiary does not apply for a (fiscal) subsidy once its competitors do, even though by applying and accepting such subsidy he subjects himself to the risk of recovery. Yet, a beneficiary that would try to limit potential damage without getting hurt in his competitive position might want to have some certainty about aid that he is about to receive.

In my opinion, the beneficiary should be allowed to ask a national court to review the matter, once a formal request to the authorities to notify is denied or left unanswered. It is the task of the national court to secure the rights that interested parties may have as a result from the direct effect of the notification- and standstill provisions of Article 88(3) EC. ${ }^{92}$ Although this Article is meant to protect the competitors of beneficiaries, it seems to me that a potential beneficiary has an explicit interest in knowing whether the alleged aid he is about to receive will be granted in accordance with Article $88 \mathrm{EC}$. If it is not evident to the national court that the alleged state aid measure does not have to be notified, it may order notification. The court may even ask the Commission for help and request information on pending cases; it may also ask the ECJ to answer prejudicial questions. ${ }^{93}$ If the national judge rules that notification was not required, then this ruling may prove to be an effective defence against recovery for the beneficiary. If

See the Communication on co-operation between the Commission and Member State courts, OJ C $312 / 7$ of 23 November 1995 and ECJ 77/72 of 19 June 1973, Capolongo v Azienda Agricole Maya, ECR 1973, pp. $611 \mathrm{ff}$. 
such ruling proves to be incorrect in the view of the Commission, it seems to me that this cannot be held against the beneficiary unless he gave incorrect or incomplete information to the national court himself.

If the national court orders the national authorities to notify a certain measure (because it is not manifest that no aid is involved or that no notification in required), it could also order the State to halt the granting of aid to competitors until the Commission issues its final decision. This would effectively protect the beneficiary's interests, else he would will miss out on the benefit his competitors received in the meantime. How unlikely this may be, this approach can also be applicable in regard to fiscal aids in direct tax regimes even though one does normally not know whether a competitor applies for the aid and to what amount due to secrecy provisions. Fiscal aids have the difficulty of being in the sphere of extreme confidentiality. This should however not withhold the national court itself - without revealing relevant fiscal data to the parties - to check whether its orders are carried out when asked to. ${ }^{94}$

As a second, more practical solution, a beneficiary could be allowed to opt-in for the 'aid' and ask for suspension of payment in the meantime. This way he becomes entitled to recurring aid normally granted during the period the aforementioned procedure at the national court is pending. Opting-in may also offer a solution for one-time-only aids that can be applied for exclusively during a limited period of time, such as a tax benefit that can only be applied for in the year of investment by checking the box on the annual tax assessment form. If the national court rules that there is no need for notification, the aid will be paid after all. The financial risk the beneficiary still has to bear is the interest disadvantage. In chapter VII.3.5 I will propose a solution to this problem for the Netherlands that could also be of interest to other Member States.

\section{Recovery of Net Benefit}

In chapter II.1.2.7 I emphasised that the actual benefit of a fiscal measure may depend on the kind of tax incentive and the fiscal side effects it may have. We should also consider that certain costs might have been incurred specifically to fulfil the necessary legal requirements to become entitled to such fiscal aid, like notary deeds or extra-ordinary accounting activities. ${ }^{95}$ These costs should be taken into account when determining the net benefit that is to be recovered. If these costs would not be taken into account, recovery would pass its goal to restore the status quo because of the beneficiary's financial setback. Should the Commission have determined the recoverable amount based on the actual benefit without taking

In countries with special fiscal courts it will often be the civil courts that have to address this particular issue, since most fiscal courts will not be competent to handle cases that concern the tax debt of a third party on request of a competitor. 
account of the aforementioned compliance costs, then annulment of its decision should be considered in order to prevent the infliction of damage.

Annulment would require the Commission to take a new recovery decision that either takes the individual circumstances into consideration of each beneficiary or leaves sufficient room to do so for the Member State involved. This is of special importance to fiscal aid schemes that concern a large number of beneficiaries. Although the net tax reduction for each of these beneficiaries may be the same depending on the form of the incentive chosen - there may still be a substantial variation in the compliance costs borne by each of them in order to become or to stay eligible for the tax incentive. If the Commission leaves it to the Member State to determine the exact amount that is to be recovered in the executive phase, there will still be a role to play for the national courts to reconsider the exact amount taking account of potential damages.

It should be considered that an annulment procedure brought before the ECJ or the CFI has no suspending effect. However, the Courts may order the suspension of a decision during the course of such action if necessary. ${ }^{96}$ Interim measures like suspension should be necessary to prevent serious and irreparable damages to the applicant and the main action must have some chance of succeeding. ${ }^{97}$ Mere financial damage is not regarded to be irreparable. ${ }^{98}$ Therefore, in matters of state aid recovery suspension is very unlikely because of lack of (manifest) urgency. ${ }^{99}$ The President of the CFI held:

"The requirement for granting suspension that there should be a risk of serious and irreparable damage is not satisfied where the applicant undertaking merely alleges purely financial damage without producing any prima facie evidence that the damage would be such as to threaten its survival and could not therefore be fully compensated for in the event of the main action succeeding." 100

The recovery of non-fiscal aids can lead to state aid complications in the fiscal sphere as well. In 1998 the Belgian government was ordered to recover the aid

\section{Article 242 EC.}

Such damages should not necessarily be imminent, yet they must be foreseeable with a sufficient degree of probability. See the Order of the President of the CFI, Joined Cases T-195/01 R and T-207/01 R of 19 December 2001, Gibraltar v Commission, ECR 2001, II-3915, paragraphs 95-96.

If aid would actually have been recovered unnecessarily, it will have to be returned to the beneficiary. In my opinion the Community Courts should order the Commission to pay an appropriate amount of interest when (1) the latter acted without notification and (2) it is determined that the investigated measure did not constitute state aid at all.

ECJ C-358/90R of 19 December 1990, Compagnia italiana alcool Sas di Mario Mariano \& Co. v Commission, ECR 1990, I-4887. 
resulting from a reduction in social security payments. This decision was upheld by the ECJ.101 The Belgian government then created a specific legal basis to make recovery possible.102 The Commission however concluded that the Belgian authorities allowed the undertakings a double tax deduction on the sums repaid. ${ }^{103}$

First of all, the corporations needed to repay only about $60 \%$ of the reduced amount, because the reduction in social security costs inherently led to a higher net profit and thus a higher corporation tax. The effective tax rate was about $40 \%$. Since the tax increase would not have occurred without the fiscal aid, the additional tax is to be taken into account to determine the net benefit. Thus, there was only an extra social security payment needed of $60 \%$. Taxable income was not adjusted for the previous years, but reducing the additional social security payments compensated the tax disadvantage and allowed an effective deduction of these costs after all.

Yet, apart from the $60 \%$-rule a specific provision was added that put the additional payments on a par with tax deductible social security payments. Enterprises would thus be allowed to deduct the $60 \%$-payments from taxable income in the year(s) of payment, although an effective 'tax' deduction had already been granted outside the fiscal sphere.

As a result of the Commission's objections to this double tax deduction, the Belgian government did propose an amendment to undo the second deduction. ${ }^{104}$

For details see Commission Decision 97/239 of 4 December 1996, and ECJ C-75/97 of 17 June 1999, Belgium v Commission (Maribel bis/ter), ECR 1999, I-3671.

The legal basis for recovery of this so-called 'Maribel bis/ter' aid is provided in Article 37bis of the Law concerning "de algemene beginselen van de sociale zekerheid voor werknemers" of 29 June 1981, as amended by Article 103 of the "Wet houdende sociale en diverse bepalingen" of 24 December 1999. ECJ C-378/98 of 3 July 2001, Commission v Belgium, ECR 2001, I-5107, paragraph 23.

Fiscale Actualiteit of 21 November 2001, no. 41, p. 3; "Programmawet" of 30 December 2001, article 46. Most recently the Commission sent a reasoned opinion to Belgium because it had failed to meet its obligation to recover the Maribel bis/ter aid (as upheld by the ECJ). This is the second stage of an infringement procedure. If Belgium does not comply within two months the Commission may refer the matter to the ECJ asking it to impose a penalty. (See chapter II.4.2.5 and press release IP/02/1072 of 17 July 2002.) 
Recovery of Unlawful Tax Incentives within the EC 


\section{RECOVERY IN THE NETHERLANDS}

\section{Introduction}

Even though the Procedural Regulation provides the procedure for the Commission to order recovery, it does not provide a procedure for Member States to execute recovery. Therefore it may be useful to look at existing national legislation. In principle recovery of state aid must take place in the same way as the recovery of other government held debts from entrepreneurs; accordingly collection of taxes as to facilitate recovery should follow normal national tax collection procedure as much as possible. The Netherlands will serve as an example in this chapter. In paragraph 2, the interpretation of legitimate expectations in Dutch (fiscal) law will be looked into briefly. Paragraph 3 will focus on the withdrawal of tax incentives for the purpose of recovery.

\section{Legitimate Expectations from a Dutch Perspective}

\subsection{Carefulness and Legal Certainty}

The government - and any other administrative body like the tax administration must carefully prepare its decisions and actions. In order to do so, it should gather the relevant facts and get the necessary insight in the interests of all parties involved. ${ }^{1}$ The government is obliged to examine whether local or national provisions on government aid violate higher legal provisions, including EC law. ${ }^{2}$ In regard to fiscal subsidies, the government (e.g. the tax administration) should thus gather the information necessary for compliance with state aid provisions. Therefore, the starting point should be that legislation, regulations and government actions are in compliance with EC law.

2 See also Nicolaĩ (1990), p. 345. 


\subsection{Legitimacy}

\subsubsection{Who raised expectations?}

If the government gave cause for the beneficiary to expect that an aid is in compliance with the state aid regime (or outside the scope of Article 87(1) EC), then the beneficiary could try to rely on these expectations in order to prevent recovery. The legitimacy of such expectations depends on several factors that will be discussed hereafter. As we will see, the national and European interpretations thereof do not always coincide, especially in regard to state aids.

The person or institution responsible for raising certain expectations must in principle be in a position to do so. Expectations cannot be raised by institutions that were not qualified to do so unless that institution appeared to be qualified as a result of the behaviour of a qualified institution. In regard to the approval of state aids, it should be called to mind that it is the exclusive competence of the Commission to decide whether a state aid is compatible with the common market or not. For this reason, a taxpayer may not rely on a promise made by the Dutch legislator (i.e. parliament, in close co-operation with the government) or the national executive (i.e. the government and the tax administration) concerning the compatibility of a tax measure unless the Commission confirms this point of view (either by means of an exemption regulation or by an explicit decision concerning the case at hand). Beneficiaries need to be aware of the fact that promises by national institutions cannot neutralise the risk of recovery. ${ }^{3}$ To my mind the Member States have knowingly and willingly limited the autonomy of their national authorities in the field of granting aids by signing the EC Treaty.

VERHEIJ argues that in a financial relation between a government body and an individual, the government should be bound to a promise made by an official from which the individual could assume that he was authorised to make such promises even though that promise is (non-evidently) illegitimate. In most of these cases there are no interested third parties involved, thus VERHEIJ. ${ }^{4}$ This kind of promise may concern state aid in a broad sense. Two matters are of interest here: first, may the beneficiary assume that the national authorities are authorised to grant subsidies, and second, may we assume that there will be no interested parties in state aid cases. If we assume that any diligent entrepreneur should be aware of the notification and stand-still provision, and that he should therefore be able to determine whether a subsidy is state aid or not, then the first assumption must be rejected. ${ }^{5}$ In regard to interested third parties, they are more or less deemed to be present in state aid cases by reference to competitors that are (threatened to be) harmed in their position. The second assumption must therefore also be rejected. 
Still, I agree with SENDEN and HANCHER that it must be taken into account that most beneficiaries are not or only marginally involved in the state aid procedure that mainly takes part between the Commission and the Member State. Putting confidence in announcements in regard to this procedure plays an important part in protecting the beneficiary as a third party. ${ }^{6}$ However, if we consider that Member States will not provide misinformation on an ongoing procedure, this lack of direct involvement is of minor importance. Only when the Member State would announce that the Commission took a final favourable decision (i.e. no aid or compatible aid), though it did not (yet) do so, then this kind of misconduct cannot be disregarded by the national court. On the other hand, the ECJ ruled that a diligent businessman would be able to check whether proper procedure was followed. If that businessman could satisfy this requirement by simple referring to an announcement by its national government on an alleged decision from the Commission - without awaiting confirmation in the form of a publication of the Commission's decision or through a press release from the Commission - then this requirement would become more or less superfluous. In my opinion, it is unlikely that the ECJ will be satisfied by such reference should it be asked to answer preliminary questions on this matter.

\subsubsection{What raised expectations?}

In regard to legitimate expectations contra legem - resulting in the payment of an amount of tax that is lower than it should be on the basis of tax legislation - the Dutch Supreme Court (hereinafter: the 'Hoge Raad') made a distinction between the conditions for such expectations depending on their alleged source: ${ }^{7}$

Responses to general inquiries are not normally able to give rise to legitimate expectations, except in special circumstances. Three conditions must be fulfilled: (1) the violation of legal provisions was not recognisable for the taxpayer, (2) the tax authorities had all the correct information to its disposal that was relevant to the case at hand, ${ }^{8}$ and (3) the taxpayer did or did not do something on the basis of the response that would lead to damages if that response would not be lived up to (apart from the fact that he will have to pay the taxes normally due after all). ${ }^{9}$

SENDEN / HANCHER (2000), p. 104.

For a more detailed description, refer to Van Leijenhorst, annotation to Hoge Raad of 7 December 2001, BNB 2002/45.

That is, the information should not have been so incorrect or incomplete that it would have led to a less favourable response or to no response at all.

The Hoge Raad explicitly considers the additional taxes legally payable not to be damages themselves. See Hoge Raad of 26 September 1979, AB 1980, 210. This will be of interest for damage claims. I.e. the recovery 
Actions taken by the tax authority may lead to legitimate expectations if the taxpayer may assume that the authorities had taken a (favourable) standpoint intentionally. For instance, issuing a tax assessment after consulting all relevant documents such as declarations could be such an action. It is still necessary to fulfil conditions (1) and (2) as mentioned above.

Explicit promises from the tax authorities in a specific case may give rise to legitimate expectations, provided that the aforementioned conditions (1) and (2) are fulfilled.

Public policy statements issued by the tax authorities concerning the actions and standpoints it will take, may lead to legitimate expectations if they are suitable to be put on a par with a regulatory provision (though it is not because of the lack of a legal basis for such regulation), provided that the statement concerns a matter that is normally within the competence of those authorities. ${ }^{10}$

In my opinion, the distinction made between the various potential sources for legitimate expectations in Dutch (fiscal) jurisprudence is rather useless in the matter of violation of state aid provisions. The comparison to be made is of another order: instead of comparing national law with national secondary regulation or actions by the national government, we now compare European law with national legislation (of any level) and national actions.

VAN WIJK ET AL. argue that in applying Community law, the national court should use the Community interpretation of legal principles if it diverts from the national one. VAN DER BURG also proposes that the national courts must sometimes use 'higher' standards in case of determining the presence of legitimate expectations compared to the ones used in purely national cases. ${ }^{11}$ As we have seen in chapter VI.4.1, the ECJ's view on the issue of legitimacy is very strict. TEN BERGE and MICHIELS acknowledge that the functioning of the national principle of legitimate expectations may be limited for the purpose of enforcing community law. ${ }^{12}$

To my mind, national legislative provisions cannot raise legitimate expectations in regard to their compatibility without the Commission's blessing, since their 'designers' (in the Netherlands: the government and parliament) can neither. For this reason, I do not consider national legislation (nor, of course, any

of benefits unlawfully received (the additional tax payable) is not to be considered causing damages. It is a mere payment of the amount of tax 'lawfully' due on the basis of national tax law (excluding the application of the unlawful tax incentive). 
secondary legislation) to be a safe haven. Moreover, I would like to add that the disposition criterion used in regard to general responses cannot play an important part at all in matters of state aid violations. It is evident that a beneficiary that has taken certain steps on the basis of arisen expectations (such as investing) may be at a disadvantage if he is not to receive the aid, when he would not have taken such steps without the prospect of getting the aid. Yet, we must consider that state aids normally intent to stimulate certain behaviour by the beneficiary. The pursued behaviour could either be taking actions like investing or staying passive (for instance by abstaining from mass job resignations). The general line in the ECJ's recovery jurisprudence indicates that in those cases where problems arise, it mostly concerns entrepreneurs or corporations that already spent the received aid. Since the element of disposition seems to be inherent in state aid cases, that element cannot play a decisive role in deciding whether or not to honour certain expectations.

\subsubsection{The need to be aware}

One of the general conditions used by the Hoge Raad is that of recognisability of the violation of legal provisions. In order to establish whether expectations are legit, it must be determined whether the recipient could (and should) have been aware of non-compliance with legal provisions.

In a government Memorandum it was stated that one may not expect a citizen to determine whether a State Body is legally authorised to grant a (non-fiscal) subsidy. ${ }^{13}$ Even though this comment only tries to emphasis that a citizen does not need to check whether the authority to grant a subsidy exists or whether it is limited by national law, it seems also applicable to other potential restrictions on granting powers like state aid provisions as a matter of principle. However, the ECJ takes the opposite view in regard to state aid restrictions; a diligent businessman should normally be able to determine whether proper procedure has been followed. ${ }^{14}$ Although state aid provisions do not formally require the recipient to check whether an aid is granted in compliance with state aid procedure, not doing so implies a waiver of protection of legitimate expectations if one takes the ECJ's view for granted. ${ }^{15}$ VAN DER BURG reminds us that subsidies must thus be critically

'Nota naar aanleiding van het Verslag', Lower House of Parliament, 1994-1995, 23 700, no. 5, p. 12, comment regarding a proposal for Article 4:23 General Administrative Law ('AWB').

ECJ C-5/89 of 20 September 1990, Commission v Germany (BUG-Alutechnik), ECR 1990, 1-3437, paragraph 14.

See chapter VI.4. In chapter VI.4.2 I have recommended that an explicit reservation should be printed on any document granting a subsidy, including tax assessments. It should be stated that (fiscal) aids may be in need of the Commission's approval under EC state aid rules (with proper reference) in order to make sure the individual is aware of these rules. 
examined, but he regards it unlikely for (Dutch) entrepreneurs to ask whether the government is allowed to grant certain subsidies. ${ }^{16}$

As the ECJ ruled, ignorance can not be an excuse for a diligent businessman to claim legitimate expectations to resist recovery. Article 3:11 of the Dutch Civil Code puts it likewise by stating that legitimate expectations are not only absent if someone knew the relevant facts or the laws, but also when he should have known them under the circumstances. Impossibility of doing the necessary research does not prevent that someone who had good reasons to doubt, can be regarded as someone who should have known the facts or the law. Thus from a civil law perspective, some research may be expected by the beneficiary if he had strong reasons to doubt. Although this provision is not directly applicable in matters of administrative procedure, it may still serve as a guideline in administrative disputes.

It should further be considered that it may not be easy for taxpayers to detect whether state aid is at stake in their tax planning process, but it may be expected from tax advisors that they are able to do so. Since most if not all entrepreneurs and enterprises hire in professional tax advice nowadays, the need for tax advisor's to be aware of state aid provisions could be attributed to those enterprises in matters of legitimate expectations. It is their professional obligation to bring any state aid inconsistencies to the attention of their clients.

\section{Tax Incentives and the General Law regarding State Taxes ${ }^{17}$}

\subsection{The Fiscal Path to Recovery}

\subsubsection{Supplemental Payment of Taxes}

The Dutch General law regarding state taxes (the 'Algemene wet inzake rijksbelastingen', hereinafter: the 'AWR') covers the core part of procedural tax law. Since Member States are held to apply every legal means available when pursuing recovery, it is necessary to examine whether fiscal procedure can be of assistance. ${ }^{18}$

VAN DER BURG (1998) p. 77.

Chapter four of the Dutch General Administrative Law ('AWB') provides general rules on subsidy procedure. Fiscal benefits are explicitly excluded from this Subsidies chapter (article 4:21(2) AWB). There is one 'exception'. If a subsidy is granted on the basis of a non-fiscal law and the amount of subsidy so determined is to be set off against tax debt to make the actual granting somewhat easier, AWB subsidy procedure will be applicable. (See the commentary to the proposal of the third amendment to the AWB, Lower House of Parliament, 1993/1994, 23 700, no. 3, p. 36.) Since there has been no such subsidy ever since this amendment came into force, to my knowledge, the Subsidy chapter of the AWB will not be further discussed. A general review of the issue of AWB subsidy procedure and recovery is provided in LUJA (2000c), pp. 247-249.

Among other XXX Report on Competition Policy 2000, SEC (2001), 694 final of 7 May 2001, p. 124. 
Fiscal procedure will be looked into next. The use of civil law concepts will be discussed in paragraph 3.2. If we take a look at tax incentives, effective recovery depends on whether an existing tax assessment may be altered once the Commission determines that a tax incentive is to be recovered (i.e. that additional tax is to be collected after all). The AWR provides several possibilities to make corrections on tax assessments. ${ }^{19}$

In regard to income tax assessments and corporate tax assessments Article 16 AWR determines that if any fact gives rise to the suspicion that (1) a tax assessment has been unjustly omitted, or that (2) the assessed amount was too little, or that (3) a tax reduction, exemption, return or credit was granted unjustly or to an amount too large, the tax inspector may demand and collect a supplementary tax payment (in Dutch: 'navordering'). ${ }^{20} \mathrm{He}$ cannot do so when that fact was known or could have been known to him at the time the assessment was issued, except when the taxpayer was of bad faith. Normally the collection may take place within 5 years from the date the assessment was issued.

In case of wage tax assessments - where the employer must withhold and pay the tax - the tax inspector may also retrospectively collect within 5 years in case the tax has not been (fully) paid. This explicitly includes the taxes due resulting from an exemption or reduction of the payable amount of tax withheld that was either unjust or for an amount too large, thus Article 20 AWR (in Dutch 'naheffing'). The main category of incentives involved will be labour related, for instance a reduction of the amount of wage tax payable in order to stimulate the hiring of long-time unemployed or handicapped staff or to compensate for the costs of certain staff training.

\subsubsection{Invalidity of Legal Provisions}

The first step in collecting additional taxes is to establish that previous tax payments are insufficient, i.e. to establish that more taxes are due than the amount already paid. If one takes the view that an 'unlawful' tax incentive is not to be applied at all, the normal tax regime (without applying such unlawful incentive) would provide for the necessary legal basis to levy taxes. ${ }^{21}$ This would result in a difference between the tax assessed (on the basis of national law) and the tax due in case national law had been applied but for the unlawful part of it that violates EC state aid provisions. This difference in the amount of taxes due could give rise to additional payment in taxes, as a first step for recovery. An example:

The issue of ex officio correction of tax assessments once the period for normal corrections has passed will not be discussed since this only applies in the benefit of the taxpayer. (Article 63 AWR.) 
Company $\mathrm{Z}$ pays an amount of 45,000 Euro in taxes. This amount is calculated as 200,000 (normal tax base) - 50,000 (special tax base reduction scheme) $=150,000$ times $30 \%$ (normal tax rate) $=45,000$. Suppose the base reduction scheme constitutes an unlawfully granted state aid. The tax that should have been due without it would be 200,000 times $30 \%=60,000$ Euro, leaving an amount of 15,000 Euro to be paid.

We must therefore examine whether it is actually possible to retroactively determine that a tax incentive has been unjustly granted, though at the time it was granted in accordance with national law. This brings us to the question whether the tax incentive could have ever been in accordance, since the system of law in all EC Member States includes the principle of obeying superior binding and directly applicable Community law like Article 88(3) EC. The ECJ has considered that the validity of measures giving effect to aid is affected if national authorities act in breach of the notification and standstill provision of Article 88(3) EC.22 It explicitly stressed that measures implementing an aid are 'invalid' owing to the breach of the 88 (3) prohibition, even if the measure itself is declared compatible by the Commission post facto. ${ }^{23}$

"Any other interpretation would have the effect of according a favourable outcome to the non-observance by the Member State concerned of the last sentence of [Article 88(3) EC] and would deprive that provision of its effectiveness", thus the ECJ.

What the consequences are of a measure being invalid, is for the national courts to decide. The Belgian Cour de Cassation declared the granting of an aid null because Article $88 \mathrm{EC}$ had not been respected, which entitled the Belgian government to recover it. ${ }^{24}$ The Italian Constitutional Court decided that a regional legislative body exceeded the limits of the powers granted to it by failing to take into account such procedural requirements. The adoption of a regional law granting state aid prior to

The Dutch text of Article 88(3) EC states that a state 'cannot' introduce state aid during the obligatory standstill period, while the English, French and German versions provide that they 'shall not' or 'may not'. The latter is obviously correct in the view of the ECJ's jurisprudence, but the textual difference is rather striking at first. The use of 'cannot' would have indicated the immediate nullity of any decision granting an aid in violation of the standstill obligation.

ECJ C-354/90 of 21 November 1991, Federation Nationale du Commerce Exterieur des Produits Alimentaires and Syndicat National des Negociants et Transformateurs de Saumon v France (French salmon), ECR 1991, 1-5505, paragraphs 12 and 16. 
the end of procedure was therefore unconstitutional. ${ }^{25}$ In an interim-decision the Austrian Constitutional Court held that not regarding proper procedure stands in the way of adoption of any aid scheme. A law containing such scheme without following procedure is therefore ineffective. ${ }^{26}$

\title{
3.1.3. The 5-Year Time Limit
}

Even if it is determined that a certain tax incentive was unjustly granted, we must still determine whether it is possible to collect the missing amount of tax under normal procedure.

The five-year time limit provided for in Articles 16 and 20 of the AWR cannot stand in the way of recovery of a subsidy. As the ECJ rules in the BUG-Alutechnik case, such a time limit may not result in the practical impossibility of recovery. In applying a time limit, the interests of the Community must be safeguarded. ${ }^{27}$ In the Alcan case it was stressed explicitly that the competent national authority must revoke a decision granting unlawful aid if ordered to, even if it allowed "the timelimit laid down for that purpose under national law in the interest of legal certainty to elapse" ${ }^{28}$ In applying the ECJ's jurisprudence, the CFI determined that

\begin{abstract}
"the provisions of national law, both those protecting legitimate expectations and those laying down a time-limit within which an administrative act creating rights may be revoked, cannot be applied so as to render practically impossible the recovery of sums required by Community law". ${ }^{29}$
\end{abstract}

It seems that the more recent Procedural Regulation sets aside any national time limit shorter than 10 years, since the Commission is explicitly authorised to recover within that period. ${ }^{30}$ If this would not be so, then a simple time-limit in any national law would make recovery almost impossible, even when it would be ordered in time according to Community procedure. When adopting that regulation the

According to the Opinion of Advocate General TESAURO of 19 September 1989 in case C-142/87, Belgium v Comission, ECR 1990, 1-959, paragraph 9 (including footnote 17), in reference to Corte costituzionale of 9 April 1963, No. 49, Foro italiano 1963, I, 859, and Corte costituzionale of 8 July 1969, No. 120 Foro italiano, 1969, I, 2069.

Österreichischer Verfassungsgerichtshof, as cited in the Conclusions of Advocate General Mischo in case ECJ C-143/99 of 8 May 2001, Adria-Wien Pipeline and Others - Finanzlandes-direktion für Kärnten, not yet published, part 11 (provisional version).

ECJ C-5/89 of 20 September 1990, Commission v Germany (BUG-Alutechnik), ECR 1990, 1-3437.

ECJ C-24/95 of 20 March 1997, Land Rheinland-Pfalz v Alcan Deutschland, ECR 1997, I-1591. 
Council considered explicitly that application of national procedure should not impede the restoration of effective competition by preventing the immediate and effective execution of a Commission decision to recover. ${ }^{31}$

\subsubsection{New Fact}

When we look into the 'new fact' that is necessary for collecting additional income and corporate taxes on the basis of Article 16 AWR, one could argue that a new fact arises from the Commission's decision that there is an (incompatible and recoverable) aid. This could bring the tax administration to the conclusion that it should not have approved of such aid in the past. However, in order to recover past fiscal benefits, the Commission's decision should be a 'new fact', which it is not. First of all, it may be assumed that the tax inspector should have been aware of the fact that unlawful aid was being granted ex officio. Second, in the Hoge Raad's interpretation a 'new fact' must be of a material and not of a legal nature. Since the material facts did not change, a change in perspective of the tax administration (or the legislator) induced by the Commission's decision cannot lead to a 'new fact'. As VAN SUILEN recalls, this is based on the principle of legal certainty. ${ }^{32}$

Article 16 AWR does not require a new fact if the taxpayer was of bad faith. This however requires that he deliberately withheld certain information from the administration or supplied incorrect information to it on purpose. ${ }^{33} \mathrm{I}$ find it hard to uphold that any businessman who fails to check whether proper state aid procedure has been followed knowingly and willingly applied for an 'unlawful' tax benefit. Would the taxpayer actually have thought about state aid provisions even for a moment before he decided not to take a further look into the issue the necessary intent to do so could be present. There should have been a certain chance that the amount of tax payable was too low (in comparison to the amount of tax due determined on the basis of national tax law, excluding provisions violating state aid procedure). ${ }^{34}$ On the other hand, when the taxpayer was unaware of the existence of state aid provisions - regardless of whether he should have been aware thereof this negligence cannot lead to bad faith for the application of Article 16 AWR.

Preamble to Council Regulation EC 659/1999, OJ L 83/1 of 27 March 1999, paragraph 13.

32 VAN SUILEN (2001), p. 391. new fact if the taxpayer 'knew or could have known' that the taxes levied were insufficient. As a result of an opinion issued by the Hoge Raad addressing the issue of legal certainty the proposal was amended as to require more than (severe) negligence for circumventing the 'new fact' requirement. See Fiscale Encyclopedie Vakstudie, Algemeen Deel, article 16 AWR, paragraph 33ff, as well as Hoge Raad 11 June 1997, BNB 1997/384. 
Taking account of the Hoge Raad's present interpretation of 'new fact' and 'bad faith' I do not expect the 'new fact' criterion to be met in most cases of fiscal state aids. ${ }^{35}$ Unless the Hoge Raad reinterprets these legal terms considerably in a manner that they no longer stand in the way of recovery - for instance, deeming every businessman to be of bad faith because of accepting unlawful aid on purpose - we must look for options other than article 16 AWR. I am of opinion that there is little or no room to bring about such considerable reinterpretation of these wellestablished legal concepts.

Therefore, one option could be not to bother about the 'new fact' requirement at all. If we consider the fiscal path to be the only method available to collect taxes, the 'new fact' criterion should be set aside on the basis of the Procedural Regulation. The latter explicitly states that
"recovery shall be effected without delay and in accordance with the procedures under the national law of the Member State concerned, provided that they allow the immediate and effective execution of the Commission's decision. To this effect and in the event of a procedure before national courts, the Member States concerned shall take all necessary steps which are available in their respective legal systems, including provisional measures, without prejudice to Community law." ${ }^{36}$

This approach could have the undesirable effect that certain parts of national procedures are applicable and other parts are not. I am not in favour thereof, especially when it is not evident that the Procedural regulation virtually overrules certain national provisions. ${ }^{37}$ If we come to the conclusion that present tax

One could argue that the taxpayer should have been aware of the 'obvious' mistake made by the tax administration when issuing the tax assessment without awaiting the Commission's approval if and when necessary. In that case, a new fact is not necessary at all. However, this exception is used only in regard to obvious writing errors in tax assessments that are easily recognisable. (See Gerechtshof Arnhem, 4 February 1993, NJ 1993/789; Hoge Raad 12 September 1997, NJ 1998/145.) In order to extend the application of this exception to state aid violations, it is necessary to assume that a taxpayer could have easily recognised the mistake at hand. If one considers the constant jurisprudence of the ECJ, one might argue that the taxpayer should have been able to check whether proper procedure was followed. On that presumption, any 'mistake' in procedure should have been recognisable. I do not expect the Dutch tax courts to follow this path. Even if a violation may be considered recognisable, it is still not so easy to detect as to constitute an 'obvious' error. 
procedure is not suited to facilitate recovery, I recommend the introduction of new legislation. I will make a proposal in paragraph 3.4 , infra.

\subsection{Civil Law Concepts for Administrative Recovery}

Apart from the fiscal path the tax administration could try to effectuate recovery on the basis of the principles of repayment of sums undue or unjustified enrichment. As we have seen before, it is not necessary that a tax incentive is recovered by means of additional taxes. Any other kind of payment will suffice as long as it covers the amount of benefit (and interest). ${ }^{38}$ However, I find the use of the civil path irreconcilable with the essence of tax procedure. Recovery of a tax incentive will lead to the additional payment of tax that was not earlier collected. The AWR provisions regarding 'navordering' cover this issue as lex specialis. If the AWR provisions are insufficient, the tax administration should not try to use the general civil legislation to get a second chance by collecting something similar to taxes without having the proper label attached to it.

Be that as it may, we will now look into the use of certain civil legal concepts in administrative procedures. In its judgement of 21 October 1996 the highest Dutch administrative court, the 'Afdeling bestuursrechtspraak van de Raad van State' (hereinafter: the 'Afdeling bestuursrechtspraak'), ruled that the general principle of law that payments not due may be recovered is also a principle of administrative law. ${ }^{39}$ This also applies to claims on the basis of unjustified enrichment. ${ }^{40}$ Although the Afdeling bestuursrechtspraak is not competent in regard to cases concerning direct taxation, its jurisprudence on administrative law is still of interest.

NIEUWENHUIS raises the question whether legal certainty and democratic legitimacy are endangered if government action is based on non-codified principles of law. In his opinion, this is not the case as long as these principles follow from unwritten law and are strongly embedded in society's notion of justice and injustice. ${ }^{41}$ Allowing general principles of law regarding recovery of sums not due and unjustified enrichment to create a competence for the government to do so when it is not explicitly codified may follow implicitly from competencies and tasks attributed by law, thus HeLDEWEG. ${ }^{42}$ As THEUNISSEN recalls the principle of legality requires a formal competence in any case, but not all competencies need to be specifically codified. Certain competencies are inherent to certain tasks attributed to the government. For instance, the competence to recover sums not due as a general principle of law is inherent to the competence to grant such sums in the first place. ${ }^{43}$

ECJ C-183/91 of 10 June 1993, Commission v Greece, ECR, 1993, I-3131, paragraph 17.

Afdeling bestuursrechtspraak, 21 October 1996, AB 1996, 496.

Afdeling bestuursrechtspraak, 26 August 1997, AB 1997, 461.

NIEUWENHUIS (1997).

HELDEWEG (2000), pp. 28-29. He provides a more extensive overview of models on 'implied powers' by several Dutch scholars in administrative law.

THEUNISSEN, as interpreted by KONING / CROMBAG (2000), p. 2. 
However, most authors agree that applying non-codified competencies detrimental to the individual's interests is far less acceptable than doing so in its favour. ${ }^{44}$

Even if one would try to use the aforementioned concepts of civil law in administrative procedures, then this is still no guarantee for success. As long as the original tax assessment is left unaltered there still is no legal basis for paying more than the assessed amount of tax. I agree with VAN SUILEN that neither a claim for repayment of sums not due nor a claim for unjustified enrichment can be an issue in regard to recovery of tax incentives. ${ }^{45}$

In regard to the first, the recovery of payments not due, done by a government body, presupposes that there is no legal basis to perform such payments. Payments done on the basis of a decision - such as a tax assessment - have their ground in that decision provided that it is valid. ${ }^{46}$ In order for an undue payment to exist, the tax assessment stating the payable amount must first be altered. As we have seen this is a problem by itself. Moreover, unlike subsidies there has not been any actual payment at all by or on behalf of the Member State. It rather was the taxpayer who paid less than he should have.

Regarding the second claim, the State willingly and knowingly agreed upon the expenditure of tax revenue so the tax benefit should not be qualified as 'unjustified' ${ }^{47}$ If the tax assessment is definitive and the assessed amount has been paid, a claim for unjustified enrichment will probably be unsuccessful because the tax debt has been formally settled. It should also be considered that the government actively contributed to the 'unjustified' enrichment. The courts may hold the government accountable for playing a major part in this enrichment and could thus decide to limit the government's claim if awarded. ${ }^{48}$

In its judgement of 21 October 1996 the Afdeling bestuursrechtspraak stated that the administrative court is only authorised to look into actions against recovery decisions, if that court is also the competent in relation to the underlying granting decision. ${ }^{49}$ Even though this ruling is not binding for tax courts, it seems to be a matter of principle. SCHELTEMA concluded that since most public payments are based on an administrative decision (which in general makes the administrative

Thus HELDEWEG (2000), pp. 35 and 39.

VAN SUILEN (2001), p. 392.

Thus SCHELTEMA (1997), p. 257.

VANSUILEN (2001), p. 392.

On the issue of 'eigen schuld' see VAN MAANEN (2001), p. 47. When we consider that the provision in law that contained the tax incentive was inapplicable from the beginning, the tax administration may have had the opportunity to demand supplemental tax payments ('navordering'). As we have seen in paragraph 3.1, supra, it is yet unclear whether 'navordering' can play a role in regard to the recovery of fiscal aids. If we assume that 'navordering' would have been possible, the courts may take into consideration that the government failed to use the legal alternative of 'navordering' instead of unjustified enrichment and thus limit any claim if awarded.

Afdeling bestuursrechtspraak, 21 October 1996, AB 1996, 496. 
court competent), actions brought before the civil court will be an exception..$^{50}$ This line of thought could also be applied in fiscal cases. The definitive granting of a fiscal benefit is based on the tax assessment. In case that assessment is to be altered to make recovery possible, there seems to be an implicit competence for the tax courts to deal with this issue. These courts are more likely to have the necessary expertise than civil courts when it comes down to the complex issue of recovering of fiscal aids. ${ }^{51}$ When the amount of recoverable fiscal aid has to be determined, it is necessary to take any consequences for the composition of the fiscal return into account. The tax courts seem the best qualified judicial body to do so.

\subsection{Payment of Interest}

In previous paragraphs we looked at the possibility to recover the face value of a fiscal aid (i.e. the nominal tax benefit itself). However, there is still the matter of interest payment that deserves our attention. The Commission will order the payment of interest in addition to the recovery of the aid granted. A legal basis for payment of interest is necessary in the Netherlands in order for the government to collect it. ${ }^{52}$ Two types of interest may be levied in regard to tax related debts.

The tax administration may collect interest ('heffingsrente') if the amount due over a certain fiscal year was not paid in full to the administration before the end of such year. ${ }^{53}$ If the tax is not paid within the fiscal year in which it arises, 'heffingsrente' is due from the first day of the new fiscal year until such time that a tax assessment is issued. If such assessment would only cover part of the amount actually due, 'heffingsrente' will be due over the remaining unpaid amount until such time that a supplementary tax assessment is issued. If the amount of tax assessed is not paid within a certain period of time another kind of interest ('invorderingsrente') is due in regard to late payment. ${ }^{54}$

In order to pay the amount of tax due before the end of the fiscal year, a taxpayer may ask for a preliminary tax assessment to be made up during a fiscal year in order to pay any tax due in time before the fiscal year ends; the tax administration may also issue such assessment on its own initiative which is more or less the rule. ${ }^{55}$ The tax inspector normally issues a preliminary tax assessment

SCHELTEMA (1998), p. 948.

Under Dutch law the civil court is the competent authority in case administrative or tax proceedings do not provide proper legal protection.

See also Afdeling rechtspraak Raad van State of 30 June 1992, AB 1993, 447.

Article 30 AWR.

Article $28 \mathrm{ff}$ of the Tax Collection Law ('Invorderingswet).

Consider that not issuing a preliminary tax assessment during the fiscal year could by itself be a kind a state aid; there will be a delay in the payment of tax until a final tax assessment is issued. From a state aid perspective, the tax inspector is not at liberty to decide not to issue a preliminary assessment to most corporations but few if a preliminary assessment could have been made for all of them on the basis of the 
based on the most recent income data gathered from tax assessments of previous years. This way, taxes can be collected within a relatively short period of time within the fiscal year concerned and directly thereafter without the tax authorities have to postpone tax collection until the final assessment is ready (normally up to 3 years after the fiscal year has ended).

Suppose at the end of 2000 the taxable income of a corporation in the Netherlands would be 110,000 Euro. In January or February of 2001 the corporation receives a preliminary tax assessment concerning the fiscal year 2001 that estimates taxable income at 110,000 Euro. In his estimation the tax inspector took into consideration that a new tax incentive would apply as of 2001, which would reduce the 2000 income of 125.000 Euro by 15,000 Euro. ${ }^{56}$ The 110,000 is to be paid in 11 monthly instalments starting at the end of February or it may be paid full at once (which entitles the taxpayer to a discount). ${ }^{57}$ The final tax assessment is issued mid 2003, which determines taxable income to be 110.000 Euro as estimated. In 2005 the Commission comes to the conclusion that the tax incentive is unlawful and is to be recovered. If we would disregard the unlawful tax incentive in redetermining the 2001 income, that income would be 125,000 Euro. With 110,000 Euro already paid, 15,000 Euro is still to be recovered plus interest.

The Commission requires the levying of interest as from the day the corporation could profit from the financial benefit. This would be the day the corporation had to pay the preliminary tax assessment, because this assessment would have been higher if the unlawful tax incentive was not considered at that time. The Dutch 'heffingsrente' is merely due as from the first day after the end of the fiscal year, presumably January 1st, 2002 until the final tax assessment is issue, for instance mid 2003. From mid 2003 until the date of actual, full payment of the recoverable amount 'invorderingsrente' would be due. Therefore there must be some kind of additional interest that is to be levied over the year 2001 itself, to be more specific, as from March 1st in our case. ${ }^{58}$

data available. However, there may be an objective justification to do so. For instance when on the basis of individual circumstances income of one corporation is expected to become negative during the fiscal year or other exception circumstances come to the attention of the tax inspector.

Ceteris paribus.

The first instalment of the preliminary assessment is normally due at the end of February of each year, at least for non-corporate enterprises.

In case of monthly instalments, the 2001 interest should be calculated as: Commission's rate times (1/11th part of the total tax due times 10 months [1 March - 31 December] +1/11th part of the total tax due times 9 months [1 April - 31 December] ... + 1/11th part of the total tax due times 0). I do not consider the 
Moreover, when the Commission orders the payment of interest it uses an interest level that differs per Member State. ${ }^{59}$ The interest rates provided for 'heffingsrente' as well as 'invorderingsrente' are often lower than the interest rate set by the Commission. Even if these two kinds of interests are to be applied in regard to state aid recovery, the interest collected would not be sufficient to perform full recovery of the benefit as ordered. The tax administration is not allowed to pursue further compensation for the interest it missed in the sphere of tax collection by using civil procedure because tax law provides explicit rules for the levying of interest from the taxpayer. ${ }^{60}$ Therefore, it may be necessary to introduce additional provisions to levy supplemental interest to match the 'proper' rate set by the Commission. In order not to complicate matters by levying up to three different kinds of interest, it should be considered not to use national procedure to collect interest despite of the equivalence requirement. The easiest solution would be to provide for a single legal provision enabling the tax authorities to levy one kind of interest as part of a recovery procedure at the rate set by the Commission.

\subsection{Creating a fiscal basis for recovery}

\subsubsection{New procedures}

Both on the fiscal and civil path, legal prerequisites may interfere with effective recovery. The ECJ explicitly stated that national law is only to be followed as long as it does not make recovery practically impossible or extremely difficult. Since there is no Community model for state aid recovery, it seems that the national authorities must divert from formal procedural requirements if they would make recovery impossible in practice. I refer to the CFI's ruling discussed in paragraph 3.1.3, supra, which explicitly stated that provisions on time limits and protection of legitimate expectations may not be applied in such cases.

Alternatively, a Member State may be forced to introduce new effective legislation if it cannot circumvent such provisions, for instance when national courts are not willing by themselves to set aside time-limits and other provisions in the Community's interest. It is yet unclear whether the obligation for a Member State to use all legal means available also includes enacting new legislation within the domestic legal system. ${ }^{61}$ Since there is no Community back-up procedure to be used in case national procedure fails to make recovery possible, it seems that Member State are more or less obliged to enact new legislation if necessary. If no such

possibility that one or more instalments have not been paid in time. In such case, 'invorderingsrente' would be due as of the expiry date. This would not affect the amount of interest due in regard to recovery. As of August 1999, the reference rate is identical for those Member States that have adopted the Euro as their common currency (Commission Notice, OJ C 241 of 26 August 1998, p. 9).

See also Hoge Raad of 8 May 1998, BNB 1998/277c*.

See chapter VI. 2 . 
obligation would exist, recovery could be circumvented by explicitly refraining from creating any (effective) basis for recovery in national law!

For now, a Community regulation on recovery is not available to give proper guidance to the Member States. If we must still find a way to recover within Dutch law in spite of it, I would prefer to use the fiscal path and attribute the task of reviewing recovery of fiscal aids explicitly to the tax courts. I support the creation of an explicit legal basis for recovery in the procedural tax laws. First, because the civil path is likely to be ineffective as long as a valid tax determination exists. Second, because tax procedure does vary very much from normal civil law action in regard to terminology and prerequisites. Therefore, I would prefer to alter existing tax law procedures or to add new tax-specific provisions in the procedural tax law instead of attempting to tackle the problem by relying on civil law or general administrative law. The new recovery procedure should address several issues:

(1) Upon a recovery order, any tax assessment may be altered as if the fiscal provisions containing the aid were not put into effect. Any time limit to do so must at least allow for recovery over a period of 10 years from the date the aid was granted. ${ }^{62}$ This provision will provide for a basis to recover within the fiscal framework. The day the first (preliminary) instalment was due should be decisive.

(2) An appropriate interest charge (using EC percentages) is due as from the first payment by instalment until the date of payment of actual payment of the tax that is to be recovered. ${ }^{63}$ National law should provide for a single legal basis to levy this interest. ${ }^{64}$ aid will interrupt this limitation period so that time will start running afresh. (Council Regulation EC 659/1999, OJ L 83/1 of 27 March 1999, Article 15(2).) Also the period will be suspended for the duration of proceedings at the European Courts.

In regard to preliminary tax assessments, the interest could go back to the moment where the first instalment is due, since the preliminary tax assessment should already have included the recovered amount of tax. For a calculation see footnote 58, supra. In case of full payment at once, interest is to be calculated from the day payment was due, notwithstanding that additional interest ('invorderingsrente') may be due in case of late payment.

Alternatively, a combination of 'heffingsrente' and 'invorderingsrente' could be used, be it that the interest rates used will normally be below the appropriate level. This would require either the introduction of special higher rates to calculate the amount of 'heffingsrente' and 'invorderingrente' for the purpose of state aid recovery or the introduction of a legal basis for a supplemental interest payment on top of normal 'heffingsrente' and 'invorderingsrente'. I would prefer the introduction of a single legal base to levy appropriate interest instead. 
(3) Recovery of the aid should follow immediately on altering the assessment, unless it would violate legitimate expectations. Legitimacy should be determined on the basis of Community standards. Payment may however be frozen as part of normal national insolvency procedures, provided that similar payments (i.e. other taxes and payments due to the government) are also frozen. ${ }^{65}$

(4) In order to determine the recoverable amount, other fiscal provisions have to be taken into consideration. Some tax incentives rule out that other incentives or special regimes are applied for at the same time. The taxpayer may request the application of those incentives or regimes that were blocked by opting for the unlawful tax incentive. Because of the necessary expertise needed to assess the exact amount of aid granted the tax courts should be competent to deal with cases involving recovery of fiscal aids.

(5) Since the tax authorities will often concur with taxpayers about the moral inappropriateness of recovery, it is not always necessary to first start an administrative procedure to contest recovery before being able to go to court. As we have seen, if the dispute is merely about whether or not to recover the primary task of the national government is to execute recovery and not to decide upon the need for recovery itself. In my opinion, the taxpayer should be allowed to skip administrative procedure and go to the tax court immediately if he contests a recovery action as such. However, in case the recoverable amount of fiscal benefit itself is subject of the dispute an administrative procedure would be appropriate. ${ }^{66}$

(6) The tax inspector can neither implicitly nor explicitly surrender his right to levy additional tax to adjust any unlawful tax benefit other than by court order. This provision is to be added, because of the possibility that - under normal tax procedure - a tax inspector's behaviour could give rise to the expectation that (undeclared) taxes due in the past would not be retrospectively levied. ${ }^{67}$

(7) The tax inspector may not grant a postponement of tax payments while administrative or court proceedings are pending, which he could under normal procedure. In order to effectuate recovery immediately, thus

SINNAEVE and SLot $(1999$, p. 1180) consider that there is a good chance that the ECJ will decide that provisions granting suspension should be disregarded by national judges as they would infringe the Procedural Regulation in regard to 'immediate' recovery. benefit or when the application of other tax benefits is part of the dispute; see item 4, supra. 
without any delay as set forth in article 14(3) of the Procedural Regulation, postponement may not be a matter for the Member State (read: the tax inspector) to decide. However, postponement may be granted for the part of the recovered amount that is contested because of the misapplication of other tax provisions (see 4, supra). ${ }^{68}$

(8) The taxpayer may request the tax inspector to have a certain tax incentive notified if it doubts whether it is unnotified state aid or not. If this is denied, it can request the tax court to assess whether there is state aid, and if so, to determine whether it must be notified. ${ }^{69}$

(9) Tax assessment should provide an explicit notice that fiscal subsidies may be subject to approval by the Commission, with appropriate legal references. ${ }^{70}$

\subsubsection{Ad-hoc Intervention}

Instead of enacting a general law that provides a legal basis for recovery, an ad hoc adjustment of tax law could also facilitate recovery. The government would need to create a basis for withdrawal of a specific tax benefit and allow for the subsequent alteration of tax assessments. I strongly prefer some kind of permanent procedure to effectuate recovery instead of creating an ad hoc solution even though I expect the need for such procedure to be limited in practice. The Dutch government is very aware of the fact that it must consider the state aid provisions in regard to fiscal and non-fiscal subsidies. My preference for a permanent procedure does not only come from the warning effect the introduction of such procedure could have, but also because it would seem more acceptable to the general public to have a standard for withdrawal instead of a sudden improvised adjustment in a specific case.

\subsection{Voluntary Suspension of Benefit}

In chapter VI.6 I have addressed the issue of how to secure the benefit of a tax incentive when the taxpayer is of opinion that a certain incentive should be notified to the Commission. If the taxpayer would ask for the suspension of a tax incentive, which he suspects to contain unlawful aid, then he would be at a loss if it is ultimately determined in court (or by the Commission) that notification was not necessary. He will receive the tax reduction later than necessary and would thus face a financial disadvantage (i.e. the interim interest missed).

A court order to grant postponement could still be possible, since an explicit draft provision stating that legal procedure may not lead to suspension of recovery was left out of the final version of the Procedural Regulation. 
A legal basis for a conditional opt-in is lacking in the Netherlands. A conditional opt-in means that a taxpayer applies for a tax incentive under the condition that the incentive will be notified and its application suspended for the duration of the notification procedure. ${ }^{71}$ Although there is no legal basis for such action, it would be theoretically possible for the tax authorities to render a provisional tax assessment that takes account of the taxpayer's request to suspend the application of a tax measure. However, within three years as from the end of the fiscal year a final tax assessment must be rendered that definitely includes the advantage of the previously suspended tax measure.

If the tax authorities render a tax assessment without fulfilling the request for suspension, the only thing left to do for our taxpayer is to pay more taxes than the amount assessed to keep up the suspension and to prevent possible recovery. If so, his tax declaration and his tax assessment would be in line with Dutch tax law but the payment itself would be too high. The beneficiary could then demand a repayment of the tax unduly paid once he is convinced that the incentive is in compliance with state aid provisions (or outside the scope of Article 87(1) EC). It will not be possible to provide compensation for the taxpayer's 'self-inflicted' interest disadvantage. The Dutch provisions on 'heffingsrente' do not allow interest to be paid in case more tax is paid than originally assessed.72

The Groskamp Judgement of the Hoge Raad may provide some guidance here. Although this judgement has been set aside by the introduction of 'heffingsrente' and 'invorderingsrente' in the AWR, its concept may still be of use.

Groskamp was granted postponement of payment of taxes pending appeal. Nevertheless, he paid the taxes because he did not want to pay legal interest over the amount due should the court dismiss the appeal. The Hoge Raad decided that - taking the position of the tax authorities into regard and the prospect of a lengthy judicial procedure - it could not be expected that Groskamp would expose himself to paying a considerable amount of legal interest. Therefore, he was entitled to compensation for the missed interest. ${ }^{73}$

There is an important difference between Groskamp and a state aid beneficiary. Groskamp declared an amount of tax but the tax inspector determined a higher

It is rather questionable whether a decision from the tax administration simply granting the incentive without containing a statement about the condition of notification, can be subjected to appeal in Dutch courts at present.

The Hoge Raad also considered that the State was able to collect interest during the time it had the additional amount of tax in its position, and that it was probably able to get a higher return on investment than Groskamp could. See Hoge Raad of 7 November 1997, Groskamp v Staat der Nederlanden, AB 1998, 221. 
amount in the final assessment, a decision that was subsequently disputed and appealed. Our beneficiary declared the 'correct' amount of tax but paid more. The striking similarity however is that both Groskamp and our beneficiary pay more than they have to, for good reasons, in order to prevent possible substantial interest payments afterwards. This Groskamp concept may be of importance in case the taxpayer assumes that notification is necessary to prevent a possible recovery, even though the tax authorities refuse to do so. I propose to create a proper legal basis to make a conditional opting-in possible and to allow the taxpayer to appeal the tax inspector's decision on this issue if necessary.

Suppose our taxpayer should have to pay an amount of $\mathrm{X}$ according to national tax law. This amount includes a disputed tax credit of 10 . The taxpayer now declares an amount of $X$, mentioning that he wants to have the tax incentive applied conditionally because he has doubts concerning state aid compliance. We now have two options:

(1) The tax inspector refuses the conditional application of the tax incentive, because he is of opinion that the taxpayers' claim for notification is unfounded. The amount assessed is therefore $X$. The taxpayer however pays $X+10$ to be on the safe side and appeals the decision not to notify. At least six variants are possible:

(a) The national court determines that there is no state aid. Subsequently there is no need for notification and the amount of 10 will be repaid. If the taxpayers claim for notification seemed reasonable to the court, payment of interest should be considered. ${ }^{74}$

(b) The national court determines that there is state aid. It rules that there is no need for notification because an aid is exempt from notification on the basis of the Exemption Regulation. The amount of 10 will be repaid. If the taxpayers claim for notification seemed reasonable to the court, payment of interest should be considered. ${ }^{75}$

(c) The national court determines that there is state aid. It rules that there is no need for notification because the Commission already settled the matter. If this was made known to the public, the taxpayer will not be entitled to any interest but he will get 10 repaid in case of existing aid.

For instance, there could have been a strong preliminary indication that the state aid definition would be met. This could be when the national court itself needed to consult the Commission or ask the ECJ for guidance, because then it is clear that the situation is not self-evident.

For instance, when there were strong indications at first that the conditions for exemption were not met or when certain parts of the regulation seemed obscure. 
(d) The national court determines that there is state aid. It determines that notification is necessary and orders so. In the end, the Commission determines that there is no state aid. Of course, 10 will be repaid. This time interest seems appropriate, since even the national court was convinced that there was state aid.

(e) The national court determines that there is state aid and orders notification. In the end, the Commission determines that there is state aid, but that it is compatible. Of course, 10 will be repaid. This time interest is not appropriate, since the benefit should not have been introduced prior to the decision concerning its compatibility. ${ }^{76}$

(f) The national court determines that there is state aid and orders notification. In the end, the Commission determines that there is incompatible state aid. Therefore, our taxpayer will not be entitled to a repayment of 10 , but he will neither have to face recovery since he never received the benefit.

(2) The tax inspector agrees with the condition and determines the amount payable on $X+10$. Simultaneously, he will ask the proper authorities to notify the incentive. The taxpayer will pay $X+10$. Options (d), (e) and (f) would apply here correspondingly. ${ }^{77}$

A single specific legal provision on the granting of interest would of course be welcome. It is needless to say that option (2) is a more theoretical one. It is rather unlikely that the tax inspector will agree that there is a need for notification, especially if the legislator or government executives take the position that there is no state aid problem at all. Yet, the legislator may simply have 'overlooked' the matter of state aid, paying no attention to it at all in the legislative process. Also, the legislator may have considered the state aid issue in general but neglected a specific, troublesome setting the taxpayer is in.

The competitor that accepted the aid immediately would not face recovery for the benefit he received prior to the date the Commission decided that the aid is compatible. Therefore I do not object to pay interest to the beneficiary that did act appropriately for the time being, as long as competitors do not face an interest charge to compensate for the interim benefit they got from receiving aid prior to the closing of proper procedure. I have already argued in chapter VI.1 that the most systematic solution would be to create a legal basis in the EC Treaty in order to levy such compensatory interest from the competitor. 


\section{CONCLUSIONS}

\section{Harmless Tax Competition as a Compromise?}

"The elimination of harmful tax competition is what is left of the objective of tax harmonisation, after its erosion by the principle of subsidiarity."

$$
\text { J. Malherbe }
$$

Harmful Tax Competition and the Future of Financial Centres in the European Union, 2000 
Chapter VIII

\section{THEORY, POLICY AND PRACTICE}

\section{A Matter of Relativity}

Every scientist must place his research in the proper perspective. Scientific theory and common practice are two different things, no matter how evident theory may seem to be. Practice always manages to find its own way, but theoretical analysis may contribute to its future development.

\section{On the Use of Tax Incentives}

Government subsidisation may sometimes be a necessity, for instance in case of extreme market failure. At the same time, it is necessary to impose strict conditions on such indispensable subsidies in order to minimise undesired (cross border) effects of subsidisation on international trade.

In chapter I I stressed that the use of tax incentives should not only be addressed from a legal point of view. Certain economic principles play their part in the system of revenue raising. In my opinion, the use of tax incentive should not be rejected as a matter of principle. It may be a suitable instrument for government policy, but not by definition. If a tax incentive is suited to do its job effectively, then it should be taken into consideration. However, there are a few pitfalls. Tax incentives should be treated as subsidies whenever possible. This means not only that their size should be visualised in the Budget, but also that the tax incentives should be subject to periodical review in order to safeguard the efficient use of government resources.

I favour the introduction of sunset clauses for any tax incentive, which terminate an incentive after a certain period of time unless it is re-enacted. For new incentives there could be a testing period of about 3 years. For subsequent reenactments these periods could be 5 to 10 years. These periods should neither be too short for reasons of legal certainty, nor too long for reasons of minimising potential spill-over and abuse. Furthermore, a tax incentive that is created for only a certain group of taxpayers should not make matters too complex for others that have nothing to do with it. The latter should be able to ignore the relevant provisions in 
tax law without difficulty. Concentrating the necessary provisions in one place so that they can be skipped when a certain box is not checked on the tax declaration form could facilitate this. Designing such an ideal tax incentive however is a challenge in itself, even without worrying about supranational legal standards.

In the present political climate politicians are not as concerned with economic principles as they should be in regard to tax expenditure. The use of the tax system as an instrument for social, economic, environmental and other policy issues has become part of the political playing field, despite of the reservations that can be made from an economic point of view. On the premise that the use of the tax system is a politically accepted method of granting financial support by the government, the legal perspective can be taken into account.

\section{State Aid Definition}

Since most Member States never expected the state aid regime to be applicable to fiscal incentives in the first place, the impact of that regime on their fiscal sovereignty was not thought through sufficiently. Now, more than forty years later the consequences thereof become visible. Nowadays it is common ground that we cannot have an effective regime to regulate state aids without including fiscal aids. I do not strive for a more lenient approach towards fiscal aids; these aids should be treated as any other kind of aid.

In chapter II I addressed the different elements of the state aid prohibition from a fiscal aid perspective. The peculiarities of the tax system do complicate the application of the state aid definition on fiscal benefits; the application of the element of selectivity is the most vague as a review of the Commission's decision indicates. Moreover, the evolution of the Commission's interpretation of the state aid definition causes uncertainty. I still wonder why the introduction of the Code of Conduct (which has no official binding status in the Community) is considered able to bring about a change in the interpretation of the state aid definition. The Commission's actions since 1999, especially the starting of several procedures on July 11th 2001, indicate that certain tax regimes are now considered 'incompatible with the common market' although these regimes have been previously assessed to contain no aid at all or to contain 'compatible' aid. I do wonder whether the ECJ will consent to this change in thought.

I have argued that the presence of a benefit must be determined by looking at the revenue loss at the level of the individual taxpayer and not by looking at the over-all revenue effects of a specific tax incentive. Also the application of the indispensable de minimis rule gives rise for concern. Not only because it's present legal basis is questionable, but also because the rule is to be applied on the level of economic entities and not on the level of legal (fiscal) entities. Last but not least, the Member State's autonomy in regulating the division of fiscal competencies in its territory may give rise to the unnecessary application of state aid provisions. Treatment of differences in taxation that are caused by regional fiscal autonomy must be carefully reviewed; they should not be put on a par with regional tax incentives too easily. 
As for the procedural aspects of state aid, it should be considered that an (unlikely) increase in the effective tax rate could lead to a substantial increase of the amount of an approved fiscal aid related to taxable income. Such increase could require renewed notification of parts of the fiscal aid scheme.

\section{Effet Utile}

In chapter III I have argued that Member States should take approved tax incentives of fellow Member States into consideration when it comes to applying anti-abuse provisions, double tax avoidance methods and CFC legislation. I do not expect the alterations in tax provisions I proposed to safeguard the effet utile of approved foreign tax incentives to be introduced in the short run. Political support is missing because safeguarding the collection of revenue is at the core of any government policy. Even in the long run, I expect that it will be hard to convince Member States that the Commission can and even may affect their corporation tax and income tax revenue for the benefit of the Community as a whole by approving tax incentives of fellow Members.

Progress in this area will have to come from national courts when called upon

by corporations that try to make bona fide use of approved tax incentives abroad and that are confronted with tax disincentives at home. I do believe that the ECJ will not hesitate to safeguard the effet utile of approved tax incentives when there is no sign of abuse, i.e. when enterprises actually do the investments and create the job opportunities for the purpose of which the incentive was approved. The ball is now in the hands of tax advisors to try and find where the legal boundaries are set. This is not the nicest job to be done, but it is a necessary one.

It appears that EC Member States hesitate to use the EC's legal procedures available to address fiscal state aids of fellow Member States. They rather try to stimulate the Commission to take the proper action without becoming directly involved. Starting court proceedings to nullify the approval of tax incentives of fellow Member States is simply not done, since Member States would not want to handle these issues of fiscal sovereignty in a more public atmosphere. Their efforts are therefore aimed at the Code of Conduct discussion, where there is more room for negotiation than in regard to state aid procedure.

\section{National Courts}

When national courts are called upon to protect the interest of either the taxpayer eligible for a tax incentive, or its competitor who is excluded therefrom, they must keep in mind that the Community interest should prevail in case of doubt. Notification as well as a standstill should be ordered if it is not beyond doubt that a tax incentive does not qualify as state aid or that it is not or no longer to be notified.

In practice the taxpayer's approach to tax incentives is a different one. He will not even hesitate to address the issue of compatibility of a tax incentive. He will rather try to profit from the incentive himself unless someone else tells him that he cannot. It seems that there is a special role here for tax advisors. They will have to look into the state aid compatibility issue at least to some extent, since clients are 
served by getting the necessary certainty in regard to large investment products and alike. Potential state aid risks should be brought to the attention of the taxpayer explicitly. As for most competitors, their aim will not be to take away the tax benefit from the beneficiary but to knock on the door of its own (or even the same) government to get the same kind of tax incentive themselves. Only when this is not possible, a competitor may want to seek ways to contest the granting of aid to the competing beneficiary.

\section{Recovery (1)}

We should ask ourselves whether the taxpayer that applied for a tax incentive accepted the risk of recovery. Recovery of state aids is not as abnormal as it once was twenty years ago. Not that recovery is to be taken for granted, but beneficiaries of state aid can no longer neglect the issue. What makes recovery problematic is that with the evolving interpretation of the state aid definition, one is not always aware that he is receiving a fiscal benefit that qualifies as state aid.

The ECJ's jurisprudence leaves little room for preventing recovery as long as the Commission does not give rise to legitimate expectations itself. This has been set forth in chapter VI. Most corporations confronted with recovery will tend to start administrative procedures just to test whether there is any possible 'exceptional circumstance' in their case that may stand in the way of recovery. Member States will also be tempted to use all judicial means available in order to prevent or delay actual recovery. These responses to recovery are legit, as long as the ECJ still refers to 'exceptional circumstances' without providing a clue what they are about.

We need further guidance from the ECJ to define 'exceptional circumstances'. It merely left a pro forma opening to safeguard legitimate expectations by a recipient of unlawful aid, a species of 'exceptional circumstances'. Whether such protection is necessary seems not to be at issue, since it is considered to be a general principle of Community law. However, there is an evident disparity between national law and prevailing EC law (and jurisprudence) when it comes down to determining if and when arisen expectations are to be regarded legit.

I do not favour the ECJ's strict approach to recovery, because there may be compelling reasons for legitimate expectations to stand in the way of recovery if national legal standards were to be used, at least in the Netherlands. This would especially be the case if top government officials frankly and publicly promise that a tax incentive is outside the scope of the state aid prohibition. Even so, I do agree with WIDDERSHOVEN that the ECJ's strict approach on legal certainty in issues of recovery is not 'entirely strange' since the basis for such certainty is laid by the Member State being the 'partner in crime' of the beneficiary from a Community point of view. ${ }^{1}$ I cannot but conclude that allowing an entrepreneur to blindly rely on statements from its national government in matters of state aid compatibility could seriously jeopardise the uniform application and enforcement of Community Law within the Member States. 
I agree with SINNAEVE that it is rather unrealistic to expect a (potential) recipient of aid to be suspicious of the aid he is receiving or about to receive, since receiving such aid is often in his own interest. ${ }^{2}$ However, this is exactly what the European Courts seem after. There is no legal obligation for the beneficiary to check whether proper state aid procedures have been followed if necessary before accepting a tax incentive. But, if these procedures have not been followed he should have done so in order to stand a chance to prevent recovery in case the tax incentive turns out to be an unlawfully granted state aid. There seems to be a special role here for tax advisors to single out potential state aid problems for their clients in time.

\section{From here to the future}

\subsection{The WTO}

Tax incentives and trade-related subsidisation will continue to be a hot issue in the upcoming years. The development of the World Trade Organization - in terms of its economic impact and the political willingness of its Member States - will be important to determine the effect of trade subsidy regulation on tax systems in practice. Compliance depends on (the threat of) WTO Members willing to start proceedings against any violation by other Members. When the concept of fiscal sovereignty is brought into play as a first line of defence in disputes involving fiscal trade subsidies, ${ }^{3}$ some peer pressure from fellow WTO Members may be needed to enforce compliance.

Stimulating export or the competitive position of domestic goods and services over imports is diametrically opposed to the concept of free and fair worldwide competition. Import and export related incentives are therefore under scrutiny. These 'prohibited' direct tax measures are the easiest to subject to SCM Agreement discipline, as set forth in chapter IV. It follows from the FSC case that countries do not have to tax profits that are not related to activities within their territory. On the other hand, they are obliged to tax export-related profits attributable to activities within their territory if similar profits that are not export-related would also be taxable. In any case profits from export transactions must be attributed to activities within and outside the tax territory on an at arm's length basis.

It is a misunderstanding that only tax incentives contingent upon export or import substitution could be subject to WTO scrutiny. Tax incentives may also qualify as actionable subsidies. In regard to these subsidies, additional criteria like specificity and adverse effects make it harder to determine whether it is allowed to act against such incentives to counter distortions of international trade.

As long as the issue of retroactive repayment has not been solved in respect to dispute settlement, the impact of the SCM Agreement will be 'limited' to trade retaliation on the bilateral or multilateral level. The tax payer himself may face the withdrawal of a tax scheme in the future, but as present practice stands there will be 
no repayment (i.e. retroactive collection) of tax benefits for now. However, a confirmation of the Australian Leather case by future panels could bring repayment closer than ever.

From the EC's perspective, its Member States should comply with international obligations that the Community took on. Even though the Commission and the ECJ should secure the latter, the WTO Agreements are still granted a status aparte. These agreements are not to be enforced in the EC Courts, except when EC legislation directly refers to them or when they are meant to be implemented in such legislation. As for the intra-community application of the SCM Agreement neither of these exceptions applies. In chapter V I provided an overview of certain potential areas of conflict between the SCM Agreement and the state aid regime. Especially the difference in treatment of de minimis aids gives rise to concern. Such aids may still be the subject of a SCM Agreement procedure, despite of the Commission's policy.

Current WTO subsidy regulations are in essence limited to trade in goods. I favour the speedy introduction of an agreement like the SCM Agreement in the services sector, in order to regulate (fiscal) subsidies in this field also.

\subsection{The European Communities}

\section{Notification and Standstill}

Within the EC, the attribution of meaningful powers to an independent authority the Commission - and the recognition of the ECJ as a supreme judicial body do make the effective implementation of state aid regulation far more easier compared to the SCM Agreement. Yet, there are still a number of major issues that have to be solved.

In a law-abiding society it must be presumed that the government will normally comply with the legal provisions that control its actions. Should a government offer some kind of financial benefit to a potential beneficiary it seems to be a matter of legal principle that the offer may be regarded as legit, unless the beneficiary himself would have provoked an illegitimate benefit. Only when it is manifest that the benefit is illegal or when the beneficiary provided incorrect information to the government in order to be eligible for a certain amount of aid, this principle should be set aside. In regard to state aid the starting point seems to be the other way around; the recipient is deemed responsible for accepting unlawful aid at all costs. It seems that a violation of the state aid notification procedure is considered to be a manifest violation from the ECJ's perspective. Yet, the difficulties and uncertainties in applying the state aid definition on fiscal measures make it hard to regard a notification violation as a manifest error at least in some cases.

Taxpayers should be allowed to get the necessary assurance they seek without missing out on tax benefits in the meantime. I therefore proposed a conditional-opt in for tax incentives that give raise to doubts about their state aid compatibility. A taxpayer should be able to ask the tax inspector to notify an incentive, and if necessary, to contest a refusal in court. The tax administration and the national courts should be provided with a legal basis to grant interest for the period during 
which the tax benefit was suspended when appropriate. I proposed a procedure for the Netherlands that can be used accordingly in other Member States. Of course, the taxpayer can already ask a national judge to postpone the application of a disputed tax incentive that is granted to his competitors in violation of the notification and standstill provision, but this very unlikely to happen if our diligent taxpayer himself could also apply for that incentive.

An enterprise is served by assurance on the validity of tax incentives, especially when its management is about to take major investment decisions or to determine the place of establishment of business units. Fiscal stimulants to invest may be of special importance to such decisions. Even if a timely investigation into state aid compatibility of such stimulants results in a decision that they are incompatible, the corporation will still be better of than when it would receive the incentive first and pay it back later on (with interest). At least the taxpayer would know in advance what's in store.

I am of opinion that the effective enforcement of the notification and standstill requirement is in need of a legal basis to make sure that interest is due to take away any interim benefit resulting from receiving (compatible) aid prior to the ending of proper procedure. The Commission should in principle be obliged to demand such interest to be paid. Regretfully, a change in the Treaty itself seems necessary before settling this matter in a Council Regulation.

\section{Recovery (2)}

Since national procedure may not make recovery impossible as such (nor may the absence of any suitable national procedure), I argue that a Member State may be forced to alter national tax collection legislation in order to facilitate recovery, if changing the law would make actual recovery possible. However, Article 14(3) of the Procedural Regulation stating that recovery has to take place "in accordance with the procedures under the national law of the Member State concerned, provided that they allow the immediate and effective execution of the Commission's decision" is too extreme. It tries to provide a balance of leaving procedural matters to the Member States, while trying to preserve the material aspects of effective recovery set forth in Community law and jurisprudence. This formula leaves the procedure that is to be used out in the open and does not contribute to legal certainty. If we must use national procedure except when parts of it stand in the way of immediate and effective recovery, beneficiaries still not know what they may expect and what procedure to prepare for.

The issue of a uniform recovery procedure will be back on the European agenda in due time, since I believe that the use of national procedures to recover will prove to be too complicated and uncontrollable in the long run, once more States accede to the EC. In the meantime, I strongly recommend that specific procedures for recovery of state aids be introduced forthwith in the Netherlands and in other Member States where necessary. Not only because such procedure can fit the ECJ's standards more properly than reinterpreting existing national legal provisions, but also because a separate procedure increases transparency. Beneficiaries will be able to better foresee what awaits them. The warning effect that 
goes with the creation of such special procedure must also be taken into consideration. Moreover, effectuating recovery of tax incentives should be done within the fiscal procedural framework. Civil law or general administrative law procedures do not properly fit the specific terminology and the peculiarities of tax systems.

I do not believe that tax legislation will become the main cause of concern for those controlling fiscal state aids, because experts in the legislative branch will focus on the issue more and more. The greatest state aid risk in the sphere of direct taxation will be in the executive branch where decisions are made at the level of the individual taxpayer. As we have seen, it is not necessary that the tax administration or the taxpayer is aware of the benefit that is conferred upon him by the misapplication of tax law. Incorrect tax assessments - as well as a 'favourable' transfer-pricing rulings for that matter - could give rise to concern. Yet the confidentiality surrounding tailor-cut decisions like assessments and rulings will make it very hard for the Commission to trace any benefit as long as no one blows the whistle. The executive branch should also be very careful when providing internal guidelines for the postponement of tax payments and alike. Even though practice is in need of setting objective criteria for these purposes, state aid regulation must not be lost sight of in doing so.

\section{Shared Responsibility}

We must learn to live with the state aid regime, because we cannot do without it if we want to maintain fair competition within a unified European market. We cannot uphold this regime without the presumption of an active participation of the beneficiary that checks the legality of his tax incentives. Be that as it may, as long as the interpretation of the state aid definition is evolving the beneficiary should not be the only party to bear the consequences of receiving unlawful aid. The Member State must bear a certain financial responsibility as well for not doing its job properly, despite of its efforts. It would be hard to defend that the beneficiary would be the one who has to face the financial consequences of recovery, while the government itself would be anything but punished in a financial sense because it receives back the aid that it previously granted. The political pressure on the officials responsible to offer a formal apology or to resign does not seem to be sufficient.

An increased level of transparency and less complicated guidelines are needed, if we want every diligent businessman to actually understand what is expected from him without having to call for expert help. This in combination with a conditional opt-in to bring an end to remaining uncertainties may make the ECJ's rigid viewpoint in matters of legitimate expectations a bit more acceptable to the general public and could make live somewhat easier for taxpayers.

\section{Subsidy Control and Tax Competition}

The EC's state aid regime and the WTO's SCM Agreement will only play a limited role in the area of harmonisation of direct tax systems. There is still a playing field 
left for Member States to create temptations in their tax system, as long as it is made attractive to more than a specific group of taxpayers. Low general tax rates are the most likely example. This however creates other fiscal problems like a shift of tax burden between taxpayers (corporations versus individuals) and between sources of income (capital, profit and labour) that are not be neglected. Be that as it may, the state aid regime and the SCM Agreement are not meant nor fit to play an important role in this part of the political arena. Neither regime will affect the core of a tax system substantially. However, they can limit the extent to which specific tax regimes may divert from the general benchmark.

\section{VIII.3 The Bottom Line in Theses}

Thesis (I) Cash subsidies are not to be preferred by definition over tax incentives when they are equally effective, provided that the latter are (1) properly visualised in the Budget, (2) subject to a sunsetclause, and (3) not causing a substantial administrative burden for non-eligible taxpayers.

Thesis (II) The definition of state aid needs further clarification in regard to (1) the application and validity of the de minimis exemption, taking account of who the actual beneficiary is of a fiscal aid, (2) the appropriate ratio of non-eligible and eligible tax payers upon which negative aids become state aid, and (3) the conditions upon which fiscal systems of autonomous regions are to be considered regional aids.

Thesis (III) State aid procedure needs further clarification in matters of fiscal aids, especially in regard to the need for additional or renotification of fiscal aids after a substantial increase in tax rates.

Thesis (IV) The introduction of the Code of Conduct is not to be put on a par with an 'evolution of the common market'; it cannot turn a measure that was no aid into (existing) aid, since the definition of state aid contains an objective legal concept.

Thesis (V) The Code's qualification of a fiscal aid as harmful cannot be the sole justification for not declaring it compatible with the common market when its economic advantages are evident.

Thesis (VI) If the Commission approves of a tax incentive for serving one of the purposes defined in Articles 87(2) or (3) EC, that incentive is not to be neutralised by the tax system of fellow EC Member States.

Thesis (VII) Member States have been unwilling to use the legal means available to them to prevent or undo the approval of fiscal aids that they considered to be harmful and ineffective. 
Thesis (VIII) Effective enforcement of the SCM Agreement provisions on prohibited subsidies requires the recovery of past benefits, despite of it being a rather unusual measure in a WTO context.

Thesis (IX) The EC state aid regime must be brought in compliance with the SCM Agreement. In cases the Commission takes a decision that violates the latter agreement, this should give cause for annulment by the Community courts.

Thesis (X) A legal basis is to be created to levy interest from beneficiaries to compensate for the interim-benefit resulting from receiving compatible state aid prior to its approval.

Thesis (XI) An extended procedural regulation should clearly provide under what conditions recovery is not to be carried out. The matter of 'exceptional circumstances' and 'legitimate expectations' is then to be settled exclusively in the Community's courts.

Thesis (XII) Unlawful tax incentives are in need of a specific fiscal framework for their recovery.

Thesis (XIII) Tax assessments should contain an explicit reservation that any aid component may be subject to approval by the Commission.

Thesis (XIV) Taxpayers should be allowed to conditionally opt-in for a tax incentive under the condition that it is notified and suspended. In case the taxpayer's doubts seem reasonable, he should be entitled to compensation (i.e. interest) for the financial loss he bore during the suspension period. 


\section{ANNEX}

The following overview of WTO Member States providing services-related tax incentives in the sectors audiovisual services, tourism, transport and banking was derived from the Working Party on GATS Rules reviews. ${ }^{1}$ As discussed in chapter IV.9, subsidies in services sectors are not yet effectively disciplined on the WTO level. This annex may serve as an indication of the frequency of these subsidies. ${ }^{2}$ Countries listed provide one or more services related fiscal subsidies. If details were included in the reviews, then these are listed explicitly. The year of evaluation is indicated per country.

\section{Audiovisual Sector}

Canada (1998);

European Union (1997); tax incentives are provided by all EU Member States Jamaica (1998); $\quad$ income tax relief for income out of motion pictures for 9 years

Korea RP (2000); $\quad$ reduction of income or corporation tax on broadcasting income by $50 \%$ for 6 years

Tanzania (2000);

WTO S/WPGR/W/25 of 26 January 1998, WTO S/WPGR/W/25/Add.1 of 29 May 2000 and WTO S/WPGR/W/25/Add.2 of 12 December 2000. 77 of the 144 WTO Members (as of 1 January 2002) have been included in these reviews. Details about the tax incentives in the selected sectors are reproduced as provided in these reports. The data supplied by the Members for review was not always complete according to the Working Party. In total 55 out of the 77 WTO Member States reported in the Working Party's reviews have been found to provide tax incentives to one or more services sectors. Apart from those sectors mentioned above tax incentives are used by a rather limited number of countries in the following sectors (number of countries indicated): construction (6); software, information technology/processing and (tele-)communications (5); distribution and wholesale/retail trade (2); real estate (2); recreation, culture and sports (1). 


\section{Tourism}

Argentina (1998);

Colombia (1996);

Costa Rica (1995);

up to $50 \%$ of investment revenue related to tourism is

Côte d'Ivore (1995);

Egypt (1999); deductable

Fiji (1997);

India (1998);

Israel (1999);

Jamaica (1998);

--

tax exemption related to investment in the tourism sector and exemption of tourist establishments apart from restaurants from paying taxes for 5 to 20 years depending on the region

hotels

Japan (1997/1998);

Kenya (1999);

Malaysia (1997);

$55 \%$ write-off on approved capital expenditure in certain tourist-related projects

$50 \%$ of profits by hotels, travel agents and tour operators in foreign exchange are exempt from income tax. The remaining $50 \%$ is exempt if re-invested in tourism projects.

Mauritius (1995);

Nicaragua (1999);

Nigeria (1998);

Philippines (1999);

Solomon Islands (1998); 5 year tax holiday and 50\% deduction in the first year for capital expenditures

Sri Lanka (1995);

Tanzania (2000);

Thailand (1995/1999);

Trinidad \&

Tobago (1998);

income tax relief up to 10 years for resort cottages and special deduction of $60 \%$ of investment in the hotel sector

$15 \%$ corporate tax rate for hotels and tax free dividend distribution for 10 years

$80 \%$ to $100 \%$ tax reduction on income for 10 years to investors in new tourism-related facilities

Turkey (1998);

discretionary 5 to 10 year tax holiday for income from hotels and $35 \%$ tax credit for tourism related venture capital

Uganda (1995);

temporary corporate income tax exemption of $20 \%$ max. of foreign exchange earnings from tourist, establishments

Uruguay (1998);

Venezuela (1996);

temporary income tax rebate of $20 \%$ of new investment in tourism, excluding land

Zambia (1996); 


\section{Transport}

Brazil (2000);

Hong Kong,

China (1998);

Costa Rica (1995);

tax exemption for international shipping services (among other)

Cyprus (1997);

Egypt (1999);

India (1998);

Fiji (1997);

Jamaica (1998);

Japan (2000);

Korea RP (2000);

Malaysia (1997);

Mauritius (1995);

Norway (1996);

Peru (2000);

tax exemption on profits and dividends, capital gains tax and income tax on crew wages for shipping companies

the Philippines (1999); ---

Poland (2000);

Singapore (2000);

Tanzania (2000);

Thailand (1995/1999); ---

Turkey (1998);

Uganda (1995);

5 year tax holiday for income from shipping

United States (1999); $\quad$---

\section{Banking and other Financial Services}

Brazil (2000);

Cyprus (1997);

Hungary (1998);

Jamaica (1998);

Korea RP (2000);

Malaysia (1997);

Mauritius (1995);

Morocco (1996);

Poland (2000);

Singapore (2000); off-shore business (including banking) taxed at $4.25 \%$ down to a full exemption if controlled from abroad corporate income tax rate of $3 \%$ for offshore trading or services companies

income tax relief on profits and capital gains for offshore banking facilities (not in use in 1998)

distributed dividends and interest on loans from offshore banks are exempt from taxes

reduction of the concessional tax on off-shore banking profits from $27 \%$ to $10 \%$ and tax holidays for certain financial activities (among other) 
Switzerland (2000);

Tanzania (2000);

Thailand (1995/1999); reduction of corporate tax rate from $30 \%$ to $10 \%$ for offshore banking (among other)

Uganda (1995);

United States (1999); 


\section{SAMENVATTING}

\section{Hoofdstuk 1}

Fiscale staatssteun is een van de meest controversiële onderwerpen op het raakvlak van fiscaliteit en internationale handel. Het staat staten vrij hun fiscale stelsel naar eigen inzicht in te richten, zolang zij zich daarbij houden aan regels van hogere orde. Ter zake van fiscale steunverlening binnen de Europese Gemeenschappen (hierna: de EG) speelt niet alleen het EG-staatssteunregime een rol, maar ook het Subsidieverdrag van de wereldhandelsorganisatie WTO. Deze studie besteedt aandacht aan de belangrijkste problemen die zich voordoen bij de toepassing van de genoemde regimes in de sfeer van de directe belastingen. In het bijzonder wordt ingegaan op de terugvordering van onrechtmatig verleende fiscale steun in het kader van het EG-staatssteunregime.

Allereerst wordt kort aandacht besteed aan de economische motieven voor steunverlening door overheden. Een van de belangrijkste motieven voor het verlenen van steun is het bieden van compensatie voor en het verhelpen van marktfalen, bijvoorbeeld wanneer achtergestelde regio's zonder de nodige fiscale stimulans niet in staat zullen zijn voldoende werkgelegenheid en hoogwaardige industrieën aan te trekken. Ook andere, politieke motieven kunnen een rol spelen zoals het voorkomen van het faillissement van bedrijven in een lidstaat die voor een aanzienlijke werkgelegenheid zorgen en het beschermen van opkomende economieën.

Vooropgesteld dat de politiek kiest voor het verlenen van steun, stelt zich de vraag of dit in een fiscaal kader kan plaatsvinden. Door middel van het verlagen van de effectieve belastingschuld voor bepaalde bedrijven kan hierin worden voorzien. Methoden die hierbij gebruikt worden zijn onder meer het toestaan van belastinguitstel (het vormen van bijzondere fiscale reserves), bijzondere aftrekposten, buitengewone afschrijvingsmethoden, bijzondere tarieven, vrijstelling en belastingkortingen.

Het accent ligt bij fiscale steunverlening vaak op het in overeenstemming brengen van fiscale steunmaatregelen met internationale regels, zonder voldoende acht te slaan op fundamentele economische beginselen van belastingheffing. Op 
zich heb ik geen principiële bezwaren tegen het gebruik van het fiscale stelsel in plaats van het geven van contante subsidies, indien beiden even effectief zijn. Voorwaarde is wel dat een fiscale subsidie, net als niet-fiscale subsidies, duidelijk wordt weergegeven in de jaarlijkse begroting. Daarnaast dient de administratieve last voor anderen dan de begunstigden van de fiscale steun niet onnodig toe te nemen. Met het oog op de bewaking van de efficiency is het aan te bevelen om aan fiscale steunmaatregelen een tijdslimiet te verbinden, zodat het parlement zich na een aantal jaren kan herbezinnen met het oog op vernieuwing van de goedkeuring.

\section{Hoofdstuk 2}

Fiscale steun kan leiden tot concurrentievervalsing, bijvoorbeeld doordat bedrijven hun producten en diensten goedkoper kunnen aanbieden dan bedrijven die dergelijke steun niet ontvangen, met een gelijke nettowinst. Hierdoor kunnen gesubsidieerde bedrijven niet alleen beter concurreren in andere lidstaten, maar zijn kunnen ook bedrijven uit andere lidstaten uit de eigen nationale markt verdringen. Derhalve is het verbod op staatssteun ingevoerd in artikel 87(1) EG.

Steun die door of namens lidstaten wordt verleend en die de mededinging op de Europese interne markt verstoort of dreigt te verstoren en daarmee de handel tussen lidstaten, is beginsel verboden, voor zover deze steun wordt verleend aan bepaalde bedrijven of sectoren en deze dus niet algemeen van aard is. Onder bepaalde voorwaarden kan steun worden goedgekeurd door de Europese Commissie (en - in uitzonderingsgevallen - door de Raad), bijvoorbeeld met het oog op stimulering van achtergestelde regio's. Andere motieven kunnen onder meer zijn het stimuleren van onderzoek, ontwikkeling en milieubeschermende investeringen. Ook het stimuleren van het midden- en kleinbedrijf behoort tot de doelstellingen, evenals het bieden van steun met het oog bedrijven van de ondergang te redden. In sommige gevallen is de Commissie verplicht steun goed te keuren wanneer deze ziet op sociale steun en steun ter dekking van de schade uit natuurrampen en andere buitengewone omstandigheden.

Om onder het staatssteunverbod te vallen dient een fiscale maatregel aan een viertal voorwaarden te voldoen.

\section{(1) Voordeel}

Er moet sprake zijn van een voordeel. De belastingplichtige dient in principe minder belasting te hoeven betalen dan onder het normale regime gebruikelijk is. Zo kan de vorming van een bijzondere fiscale reserve worden toegestaan die onder het normale regime niet gevormd zou mogen worden. Door bepaalde winsten in een reserve te stoppen wordt de belasting hierover uitgesteld totdat de reserve vrijvalt. Ook bijzondere afschrijvingsmethoden kunnen tot een voordeel leiden, wanneer wordt toegestaan om sneller af te schrijven dan gebruikelijk. Hierdoor wordt in de eerste jaren minder belasting betaald en later meer. Door dit verschil in betalingstijdstip ontstaat een tijdelijk financieringsvoordeel (het genieten van rente gedurende de tijd dat de belasting nog niet betaald hoeft te worden); hetzelfde geldt bij het verlenen van uitstel van betaling. Dat het kwijtschelden van belasting 
eveneens een voordeel oplevert behoeft geen nadere uitleg. Het uiteindelijke netto voordeel is onder meer afhankelijk van het effectieve belastingtarief.

Bij het bepalen van de aanwezigheid van een voordeel doen zich enkele problemen voor. Allereerst is niet bekend waar het omslagpunt ligt tussen voor- en nadeel, dat wil zeggen dat niet bekend is hoeveel procent van de belastingbetalers van een bepaald voordeel moet genieten om te kunnen zeggen dat niet langer sprake is van een voordeel voor degenen die steun ontvangen, maar van een nadeel voor degenen die geen aanspraak kunnen maken op een fiscale steunmaatregel. Daarnaast kan een voordeel zich ook in de marge voordoen. Indien fiscaal 'gunstige' verrekenprijzen worden gehanteerd voor transacties in concernverband, dan kan daarin een voordeel schuilgaan. Deze aard van voordeel is evenwel voor de Commissie niet eenvoudig te traceren.

Het Hof van Justitie heeft herhaaldelijk bepaald dat het gelijk trekken van de nationale belastingdruk voor een bepaalde sector met die in het buitenland, niet eraan af doet dat op nationaal niveau een voordeel wordt genoten vergeleken met andere sectoren in dezelfde lidstaat. Echter, indien een belastingplichtige een belastingvoordeel krijgt vanwege het feit dat hij op basis van contracten met de overheid bepaalde onrendabele taken moet uitvoeren in het algemeen belang, dan hoeft niet altijd sprake te zijn van een netto-voordeel zolang de vermindering van belasting niet meer bedraagt dan de extra kosten die met die taken gemoeid zijn.

\section{(2) Aanwending van staatsmiddelen}

Het voordeel moet uit staatsmiddelen afkomstig zijn. Dit is bij fiscale maatregelen per definitie het geval. Ik ben van mening dat voor het vaststellen of aan dit vereiste is voldaan niet van belang is dat per saldo staatsmiddelen zijn gebruikt (d.w.z. dat per saldo de belastingopbrengst wordt verminderd). Naar mijn mening is doorslaggevend dat aan de belastingplichtige een fiscaal voordeel toekomt.

Het is niet noodzakelijk dat een voordeel opzettelijk wordt verleend. Ook indien door een vergissing van de inspecteur minder belasting verschuldigd is, wordt in beginsel aan het tweede vereiste voldaan. Naast directe fiscale voordelen uit staatsmiddelen kunnen ook indirecte voordelen een rol spelen. Het verlenen van een belastingvoordeel aan particulieren die spaargeld in een bepaald fonds beleggen, kan leiden tot een voordeel voor ondernemers, indien zij uit datzelfde fonds een lening kunnen verkrijgen tegen zeer gunstige voorwaarden. Zo kan een lagere rente worden overeengekomen, zonder dat de netto-opbrengst na belasting voor de particulier achterblijft bij de opbrengst van andere beleggingen.

\section{(3) Verstoring van de mededinging}

Het voordeel moet de mededinging en handel tussen lidstaten (dreigen te) verstoren. Aan deze voorwaarde zal in principe altijd worden voldaan, behalve in die sectoren waarbij geen grensoverschrijdende concurrentie aan de orde is.

Steun die onder een niveau van 100.000 Euro per drie jaren blijft wordt in principe geacht geen verstoring teweeg te brengen. Deze zgn. de minimis steun hoeft dan ook niet te worden aangemeld (met uitzondering van steun voor bepaalde 
gevoelige sectoren en exportgerelateerde steun). Volgens mij is het echter niet mogelijk om op basis van een dergelijke drempel steun uit te zonderen van het staatssteunverbod, nu het EG-Verdrag hierin niet voorziet. Hiervoor is mogelijk een verdragswijziging noodzakelijk. Een probleem dat zich in het bijzonder voordoet bij de de minimis steunregeling is dat zal moeten worden getoetst of de uiteindelijke begunstigde van het voordeel aan het plafond voldoet. Hierdoor dient in een aantal gevallen door (fiscaal)juridische entiteiten heen te worden gekeken om na te gaan bij welke economische entiteit een fiscaal voordeel uiteindelijk terechtkomt.

\section{(4) Selectiviteit/economische activiteit}

Het voordeel moet selectief worden verleend en betrekking hebben op een economische activiteit. Op grond van dit laatste valt steun aan niet-commerciële instellingen veelal buiten het verbod, zolang geen sprake is van activiteiten waarmee geconcurreerd kan worden met commerciële aanbieders.

Selectiviteit (ook wel specificiteit genoemd) is veruit het moeilijkste vereiste. Het brengt een scheiding aan tussen generieke en specifieke fiscale maatregelen. Het is vaak inherent aan een fiscale maatregel dat bepaalde belastingplichtigen er meer van profiteren dan anderen. Zo zal een extra aftrekpost voor loonkosten van laaggeschoolde werknemers slechts ten goede komen aan hen die deze werknemers in dienst hebben. Investeringsvoordelen zullen slechts toekomen aan hen die daadwerkelijk investeren. Anderzijds zal steun die slechts toekomt aan grote bedrijven niet als generiek worden gekwalificeerd. Indien per definitie kleinere bedrijven worden uitgesloten kan sprake zijn van selectiviteit.

Zo zal ook sprake zijn van selectiviteit als slechts ondernemingen die gevestigd zijn in een bepaalde regio voor een voordeel in aanmerking komen of slechts zij die exporteren. In het geval de belastingautoriteiten een discretionaire bevoegdheid hebben en op basis daarvan deels naar eigen inzicht mogen beslissen aan wie een fiscaal voordeel toekomt, wordt verondersteld dat sprake is van selectiviteit zolang het tegendeel niet bewezen is. Voordelen die slechts aan bepaalde sectoren toekomen zijn in de regel eveneens selectief van aard.

Een belangrijk probleem dat zich voordoet bij regiogebonden voordelen is dat deze deels veroorzaakt kunnen worden door regionale fiscale autonomie. Indien een locale overheid zelfstandig bepaalde fiscale bevoegdheden heeft, dan dienen deze niet zonder meer op een lijn gesteld te worden met regionale voordelen die verleend worden door de centrale overheid. Hierbij dient naar mijn mening te worden nagegaan of fiscale autonomie slechts met het oog op het verlenen van regionale fiscale voordelen in het leven is geroepen, of dat het deel uitmaakt van een breder takenpakket van autonome medeoverheden. In het laatste geval dient te worden nagegaan in hoeverre het autonome fiscale stelsel niet alsnog tot regionale steun leidt, mede gelet op de financiering van de aan de verschillende overheden toebedeelde taken. 


\section{Procedure}

Alvorens steun die aan alle bovenstaande voorwaarden voldoet van het verbod kan worden ontheven, zal de Europese Commissie de maatregel onderzoeken. Een lidstaat is op grond van artikel 88(3) EG verplicht een nieuwe steunmaatregel vooraf aan te melden bij de Commissie en met de invoering ervan te wachten totdat ontheffing van het verbod is verleend. Bepaalde steunmaatregelen zijn evenwel vrijgesteld van deze procedure (opleidingssteun, steun aan het midden- en kleinbedrijf, de minimis steun); zij worden geacht te zijn goedgekeurd indien aan bepaalde voorwaarden is voldaan.

Indien nodig zal de Commissie, na een eerste onderzoek, een formele procedure openen om alle betrokken partijen en derden in de gelegenheid te stellen hun standpunten en bezwaren kenbaar te maken. Deze procedure is vastgelegd in artikel 88(2) EG en verder uitgewerkt in de zgn. procedurele verordening (nr. 659/1999). De Commissie zal het goedkeuren van steun (formeel: het verenigbaar verklaren met de interne markt) moeten afwegen tegen de daaraan verbonden gevolgen. Zo zal het effect van een belastingvrijstelling ter stimulering van een bepaalde regio moeten worden afgewogen tegen de mate van concurrentievervalsing die daardoor op de communautaire markt wordt veroorzaakt.

Fiscale steun die wordt ingevoerd zonder dat deze van het verbod is uitgezonderd kan worden teruggevorderd van de belastingplichtige, wanneer de Commissie deze steun na een formeel onderzoek niet van het verbod ontheft. Slechts het daadwerkelijke voordeel kan worden teruggevorderd. Zo dient bij de bepaling van het financiële voordeel door vermindering van de belastinggrondslag onder meer rekening te worden gehouden met het effectieve tarief dat op de belastingplichtige van toepassing is.

Substantiële wijzigingen in goedgekeurde maatregelen geven in beginsel aanleiding tot hernieuwde aanmelding en het afwachten van een herbeoordeling van de fiscale maatregel in kwestie. Ook een wijziging in het normatieve fiscale stelsel, zoals een stijging van het belastingtarief, kan aanleiding geven tot een aanvullende of heraanmelding wanneer het netto-voordeel daardoor aanzienlijk toeneemt.

Begunstigden, concurrenten en lidstaten kunnen het oordeel van de Commissie inzake goedkeuring of het achterwege laten daarvan aanvechten voor het Gerecht van eerste aanleg c.q. het Hof van Justitie. Veelal zal hier sprake zijn van een marginale toetsing, nu de Commissie in de meeste gevallen aan brede beoordelingsmarge mag hanteren. Echter voor wat betreft de vraag of een bepaalde fiscale maatregel een steunmaatregel is die voldoet aan alle vereisten van het verbod kunnen de gerechtshoven ten gronde toetsen. Het betreft hier namelijk een objectief juridisch begrip. Datzelfde geldt voor de vraag of van nieuwe steun dan wel van bestaande steun sprake is. Voor de laatste categorie van steun dreigt namelijk geen terugvordering, zolang de Commissie de opheffing ervan niet heeft bevolen. Bestaande steun is niet alleen steun die reeds goedgekeurd is maar ook, onder meer, steun die reeds voor de toetreding van een lidstaat tot de EG werd verleend. Voor deze steun geldt in eerste instantie niet de eerdergenoemde formele procedure. Wel kan de Commissie voorstellen om een steun die zij niet langer 
wenselijk acht in te trekken. Wordt hieraan geen gevolg gegeven door de lidstaat dan kan de Commissie, na een formeel onderzoek, alsnog opdracht geven tot stopzetting.

Indien de Commissie een formeel onderzoek start naar nieuwe steun, dan kan de beschikking waarmee zij de procedure start in rechte worden aangevochten. Een dergelijke procedure brengt, zoals gezegd, de dreiging van opschorting en terugvordering met zich mee hetgeen de handelspositie van een onderneming ernstig kan beïnvloeden. Indien bij het Hof c.q. het Gerecht wordt betoogd dat geen sprake is van nieuwe steun, of in het geheel niet voldaan is aan de steundefinitie van artikel $87(1) \mathrm{EG}$, dan is de formele procedure namelijk ten onrechte geopend.

\section{Hoofdstuk 3}

In de gedragscode inzake de belastingheffing van ondernemingen zijn criteria vastgesteld voor de beoordeling van de 'schadelijkheid' van fiscale maatregelen, met het oog op het beschermen van de aantasting van nationale belastingopbrengsten door voordelige, speciale buitenlandse regimes. De gedragscode streeft naar de afschaffing van dergelijke maatregelen binnen de EG. In verband hiermee is de Commissie overgegaan tot een herbeoordeling van bepaalde fiscale steunmaatregelen die mogelijk 'schadelijk' kunnen zijn. De gedragscode heeft officieel (nog) geen bindende juridische status binnen de EG, hoewel zij toch bepaalde verplichtingen oplegt aan de lidstaten onderling.

Bepaalde fiscale maatregelen worden nu onderzocht terwijl de Commissie in het verleden heeft vastgesteld dat zijn buiten de definitie van het staatssteunverbod vielen. Daarnaast worden bepaalde fiscale maatregelen onderzocht die in het verleden zijn goedgekeurd maar waarvan een langere instandhouding door de Commissie niet langer wenselijk wordt geacht. Ook worden enkele niet-aangemelde maatregelen onderzocht die vermoedelijk steun bevatten. De Commissie zal in het bijzonder bij haar onderzoek naar verrekenprijzen rekening moeten houden met het feit dat het uiteindelijke voordeel per belastingplichtige kan verschillen en dat een bijzondere richtlijn voor verrekenprijzen niet zonder meer voor een ieder tot een voordeel hoeft te leiden.

Bij het argument van de Commissie dat bepaalde fiscale maatregelen door de ontwikkeling van de interne markt steunmaatregelen zijn geworden zet ik vraagtekens. Het steunbegrip is een objectief rechtsbegrip. De ontwikkeling van de interne markt zal in de regel niet tot gevolg hebben dat een bestaande maatregel tot steun wordt. Een fiscaal voordeel zal niet plots ontstaan waar dit tot voor kort niet het geval was. Dat de Commissie in een bepaald geval een voordeel niet heeft onderkend doet niet eraan af dat objectief gezien een voordeel aanwezig was. De ontwikkeling van de interne markt zal in de regel evenmin invloed hebben op het antwoord op de vraag of wel of niet sprake is van het gebruik van staatsmiddelen. Ook zal een fiscale maatregel niet van de een op de andere dag specifiek van aard worden. Waar de ontwikkeling van de interne markt wel kan doorwerken met betrekking tot staatssteun, is het (derde) element van invloed op de mededinging en de nadelige beïnvloeding van het handelsverkeer. 
Ik betoog dat fiscale maatregelen die door de Commissie zijn goedgekeurd en waarvan de goedkeuring niet of niet succesvol is aangevochten door andere lidstaten, tot hun recht moeten komen. Indien de Commissie fiscale steun bijvoorbeeld toelaat voor regionale stimulering, vooropgesteld dat een bepaald investeringsniveau wordt bereikt of een minimum aantal (permanente) banen wordt gecreëerd, dan dient deze steunmaatregel een gezamenlijke doelstelling van de gemeenschap en haar lidstaten. Andere lidstaten dienen de nodige maatregelen te nemen om te voorkomen dat hun eigen nationale fiscale stelsel het uitnodigende effect van een goedgekeurde, buitenlandse steunmaatregel tenietdoet. Goedkeuring van een steunmaatregel met het oog op een communautaire doelstelling als verwoord in de artikelen 87(2) en (3) EG dient er in het licht van artikel 10 EG toe te leiden dat lidstaten zich onthouden van maatregelen die aan de verwezenlijking van een dergelijk doel in de weg staan.

Zo zal een buitenlands belastingvoordeel voor een bedrijf dat besluit in een bepaalde regio een vestiging te openen, teniet worden gedaan indien daardoor in de eigen lidstaat van de hoofdvestiging meer belasting verschuldigd wordt enkel als gevolg van het in het buitenland verleend goedgekeurd voordeel. De toepassing van een systeem van verrekening, als fiscaal geaccepteerde methode ter voorkoming van dubbele belasting, kan een zodanig neutraliserend effect hebben. Hetzelfde geldt voor anti-ontgaansbepalingen die erop zien dat een eventuele vrijstelling niet langer wordt verleend indien op inkomsten uit de andere lidstaat een bijzonder (goedgekeurd) regime van toepassing is.

Wanneer een lidstaat van mening is dat een (fiscale) steunmaatregel van een andere lidstaat niet (langer) geschikt is om het doel te bereiken, dan dient zij de Commissie hierop te wijzen. Het is de taak van de Commissie regelmatig goedgekeurde steunmaatregelen te evalueren. Desnoods dient te lidstaat tegen het niet-optreden van de Commissie bij ineffectieve steun actie te ondernemen om de goedkeuring aan de steun te ontnemen. Lidstaten maakten, althans in het verleden, niet of nauwelijks gebruik van de mogelijkheid hun bezwaren tegen fiscale steunmaatregelen van andere lidstaten kenbaar te maken in het kader van een formele procedure, hoewel juist in deze fase de mogelijkheid geboden wordt om goedkeuring te voorkomen.

De Commissie mag geen fiscale steunmaatregelen goedkeuren die andere bepalingen van het EG-Verdrag schenden, ook al hebben deze maatregelen een bepaald gewenst effect. Hierbij valt te denken aan regionale investeringssteun die vereist dat het hoofdkantoor van een concern (de moedermaatschappij) in de desbetreffende regio wordt gevestigd en waarbij geen genoegen wordt genomen met een vaste inrichting.

\section{Hoofdstuk 4}

Op het internationale vlak bestaat eveneens een subsidieregime. Het WTO Subsidieverdrag geeft regels voor subsidies die van invloed kunnen zijn op de internationale handel. Subsidies die (mede) afhankelijk zijn van export of die importsubstitutie vooropstellen (d.w.z. het verkiezen van in het binnenland geproduceerde gesubsidieerde producten boven geïmporteerde producten) zijn verboden. Staten 
die bij de WTO zijn aangesloten kunnen met elkaar over dergelijke subsidies in contact treden. Indien een staat niet bereid is een verboden maatregel in te trekken kan een onafhankelijk panel gevraagd worden te beoordelen of het verbod is overtreden. Zo ja, dan kan intrekking worden 'aanbevolen'. Wordt hieraan niet voldaan, dan kan de klagende staat - in afwachting van de naleving van de 'aanbeveling' - desnoods handelsmaatregelen treffen, zoals het instellen van douaneheffingen op zowel gesubsidieerde als niet-gesubsidieerde goederen van die andere lidstaat, die naar het eigen land geïmporteerd worden. Tegen een uitspraak van het panel staat beroep open bij een onafhankelijk beroepsorgaan. In de onpartijdigheid van de betrokkenen en andere waarborgen met betrekking tot het verloop van deze quasi-judiciële procedure wordt voorzien.

Naast verboden steunmaatregelen bestaat er ook een categorie van maatregelen waartegen opgetreden kan worden indien aan bepaalde voorwaarden is voldaan. Ten eerste dienen deze maatregelen specifiek van aard te zijn. Hiervan kan gedacht worden aan regionale beperkingen (welke niet voortvloeien uit regionale autonomie) en aan steun die verleend wordt aan individuele bedrijven of sectoren. Daarnaast dient te worden aangetoond dat de handelsbelangen van de klagende staat daadwerkelijk en substantieel worden geschaad. Ook hier kan aanpassing of opheffing van de maatregel uiteindelijk worden 'afgedwongen'.

Er heeft nog een categorie van maatregelen bestaan waartegen in beginsel geen actie mogelijk was. Dit waren niet-specifieke maatregelen alsmede specifieke maatregelen op het terrein van regionale steun, milieu-investeringen en onderzoek en ontwikkeling. Wegens gebrek aan consensus over handhaving van deze categorie is deze ultimo 1999 vervallen. Voor niet-specifieke maatregelen betekent dit dat zij in beginsel buiten enige categorie vallen.

Een staat die lid is van de WTO heeft de mogelijkheid om in plaats van of tijdens het aanvechten van de subsidie zelf compenserende heffingen op geïmporteerde gesubsidieerde goederen te hanteren om het negatieve effect van die goederen op de binnenlandse industrie zo veel als mogelijk ongedaan te maken, voorzover de subsidiërende staat niet bereid is de subsidie in te trekken of deze zodanig aan te passen dat het negatieve effect ongedaan wordt gemaakt. De compenserende heffing mag het bedrag van de subsidie niet overschrijden.

In deze studie worden de karakteristieken en de mate van voordeel van bepaalde fiscale voordelen besproken. Daarbij is in het bijzonder aandacht besteed aan de procedure inzake het Amerikaanse Foreign Sales Corporation (FSC) regime. Uit deze procedure komt naar voren dat het lidstaten vrij staat te kiezen tussen fiscale systemen die gebaseerd zijn op belasting van het wereldinkomen of het inkomen uit het territoir van een lidstaat. Echter, deze keuze dient consequent te worden doorgevoerd. In beide gevallen dienen inkomsten uit export in de heffing te worden betrokken net als andere bedrijfsinkomsten; bij een territoriaal regime slechts voor zover deze inkomsten aan de activiteiten binnen het territoir kunnen worden toegerekend. Een dergelijke toerekening dient volgens het 'at arm's length' beginsel plaats te vinden.

De vraag of sprake is van een voordeel dient niet slechts aan de hand van de juridische vormgeving van de belastingwet beantwoord te worden. De norm zal objectief bepaald moeten worden. In principe is van een voordeel geen sprake 
indien vermindering van de nationale belastingschuld wordt verleend met het oog op voorkoming van dubbele belasting. De voorwaarden die voor een dergelijke vermindering worden gesteld dienen niet onnodig selectief te zijn; inkomsten die worden toegerekend aan het eigen territoir van de staat die de vermindering verleent mogen in principe niet voor vermindering in aanmerking komen.

Het WTO Subsidieverdrag voorziet vooralsnog niet in het terugvorderen van verboden subsidies, maar slechts in het afschaffen ervan voor de toekomst. Hoewel ik de terugvordering van verleende verboden subsidies op basis van de tekst en doelstelling van het Subsidieverdrag mogelijk acht, blijft dit onderwerp vooralsnog zeer omstreden. Het WTO subsidieregime is vooralsnog slechts van toepassing op de handel in goederen en niet op dienstverlening.

\section{Hoofdstuk 5}

De EG en haar lidstaten zijn allen lid van de WTO. In die hoedanigheid zijn zij derhalve gebonden aan het Subsidieverdrag. Indien WTO-lidstaten dit verdrag overtreden, dan zal de Commissie hiertegen zonodig optreden, mede ten behoeve van de lidstaten, nu internationale handel binnen de competentie van de EG valt.

Een concurrent van een Europese onderneming die subsidie ontvangt kan geen beroep doen op de verplichtingen van het Subsidieverdrag om de eventuele goedkeuring van een dergelijke subsidie in het kader van het staatssteunregime te doen vernietigen Het Hof van Justitie staat niet toe dat op het Subsidieverdrag een beroep wordt gedaan in procedures voor het Hof en het Gerecht, nu dit verdrag niet in Europese regelgeving is vastgelegd of implementatie ervan anderszins beoogd is voor wat betreft de werking ervan tussen EG-lidstaten. Hoewel het Subsidieverdrag bindend is voor de EG en de lidstaten op grond van artikel 300(7) EG blijft het Hof hier terughoudend, met name omdat directe werking van de WTO verdragen in EG-recht afbreuk zou kunnen doen aan de gelegenheid tot onderhandelen die deze verdragen aan de staten bieden. Daarnaast overweegt het Hof dat ook andere belangrijke handelspartners aan de WTO verdragen geen interne werking toekennen en dat de Europese Raad in haar eigen preambule bij het verdrag aangeeft dat de verdragen geen directe werking zullen hebben. Ik zet mijn vraagtekens bij deze redenatie, omdat het WTO verdrag expliciet voorziet in een nalevingsverplichting welke op grond van artikel 300(7) EG normaliter zou moeten doorwerken in het interne EG-recht. Dit geldt in het bijzonder voor het subsidieverdrag dat enkele duidelijke verbodsbepalingen bevat.

Met name een begunstigde van steun zal baat hebben bij een toets op conformiteit met het Subsidieverdrag alvorens de Commissie staatssteun goedkeurt; zo niet dan kan goedgekeurde steun in voorkomende gevallen een gevoel van schijnzekerheid opwekken. Goedkeuring van staatssteun door de Commissie garandeert niet dat dergelijke steun met het Subsidieverdrag in overeenstemming is. Dit geldt evenmin als een subsidie buiten de definitie van artikel 87(1) EG valt. Zo kent het Subsidieverdrag geen de minimis uitzondering en kent zij sinds het jaar 2000 geen bijzonder regime meer voor regionale ontwikkelingssteun. 
Anders dan het EG-staatssteunregime is de handhaving bij de WTO minder rigide. Zo zal het effect van handelsmaatregelen afhangen van het belang van de markt van de staat die deze maatregel neemt voor de industrieën uit de steunverlenende staat. Ook is terugvordering in WTO verband niet gebruikelijk en bovendien zeer omstreden, hoewel dit voor een effectieve handhaving van het verbod op steun voor export en importsubstitutie noodzakelijk is.

\section{Hoofdstuk 6}

De bevoegdheid om onrechtmatig ingevoerde steun terug te vorderen vloeit volgens het Hof van Justitie impliciet voort uit de bevoegdheid om de opheffing van dergelijke steun te eisen. Terugvordering is het logische gevolg van een overtreding van de aanmeldings- en opschortingsplicht en is derhalve geen disproportionele maatregel, aldus het Hof.

Indien een onrechtmatig ingevoerde steunmaatregel uiteindelijk wordt goedgekeurd, dan kan deze niet worden teruggevorderd, ook niet voor wat betreft de steun die is verleend terwijl de opschortingsplicht nog van kracht was. Het EGVerdrag biedt geen grondslag voor het heffen van een compenserende rente over de periode dat de steun onrechtmatig in het bezit was van de steunontvanger. Ik stel voor een dergelijke bevoegdheid te creëren om overtreding van de opschortingsverplichting effectief te kunnen sanctioneren.

De wijze van terugvordering wordt in principe aan de lidstaat overgelaten. In beginsel zal terugvordering moeten plaatsvinden volgens de regels die gelden voor nationale steun die is verleend in strijd met nationale bepalingen, zolang deze regels niet aan effectieve terugvordering in de weg staan, aldus het Hof van Justitie. Uiteindelijk komt het erop neer dat de lidstaten vrij zijn in het bepalen van de procedure voor terugvordering en het aanwijzen van de bevoegde autoriteiten en gerechtelijke instanties. Het materiële deel van terugvordering wordt echter beheerst door EG recht.

Terugvordering mag achterwege blijven indien dit 'absoluut onmogelijk' is. Tot op heden heeft het Hof van Justitie geen onmogelijkheid van dien aard gesanctioneerd. Financiële problemen voor zowel de begunstigde als de staat, alsmede aanzienlijke administratieve lasten maken terugvordering in ieder geval niet onmogelijk. Zouden zich onvoorziene problemen voordoen, dan dienen de lidstaten met de Commissie in overleg te treden en voorstellen te doen om deze problemen te overwinnen. Een bevel van een nationale rechter om niet terug te vorderen zou wellicht als een absolute onmogelijkheid kunnen worden aangemerkt; de kans dat dit gebeurt lijkt echter klein nu de nationale rechter zich naar communautaire maatstaven dient te richten.

De bescherming van gerechtvaardigd vertrouwen is als beginsel van gemeenschapsrecht erkend en kan derhalve eveneens aanleiding zijn om niet terug te vorderen. Het Hof van Justitie stelt echter dat een behoedzame ondernemer normaliter in staat zal zijn na te gaan of de aanmeldings- en opschortingsprocedure is gevolgd. Indien hij dit niet heeft gedaan, dan is een gerechtvaardigd vertrouwen nagenoeg uitgesloten. Verwachtingen die door de nationale overheid c.q. de wetgever zijn gewekt kunnen geen vertrouwen wekken, nu de nationale overheid 
niet bevoegd is steun in de zin van artikel 87(1) EG zonder meer in te voeren. Ook het langdurig achterwege blijven van maatregelen om onrechtmatige steun te niet te doen van de zijde van de Commissie is in principe niet voldoende om een gerechtvaardigd vertrouwen op te wekken, zolang de Commissie van haar zijde niet op andere gronden bepaalde verwachtingen heeft gewekt. Zelfs als een vertrouwen al gerechtvaardigd is, dan nog dient de bescherming ervan te worden afgewogen tegen het belang dat de gemeenschap heeft bij terugvordering (het herstel van de onderlinge concurrentiepositie tussen de gesubsidieerde en de nietgesubsidieerde ondernemer op de gemeenschappelijke markt).

De vraag of terugvordering voorzienbaar was hangt samen met de noodzaak voor begunstigden van staatssteun om zich bewust te zijn van het staatssteunregime en de gevolgen die het met zich meebrengt. Om aan het standpunt van het Hof van Justitie, dat een behoedzame ondernemer in staat dient te zijn na te gaan of de correcte procedure is gevolgd, meer realiteitsgehalte te geven, stel ik voor belastingaanslagen te voorzien van een waarschuwing die wijst op de mogelijke toepasbaarheid van het staatssteunregime.

In dit onderzoek wordt de mogelijkheid geopperd om boetes op te leggen aan de lidstaat indien deze niet aan zijn aanmeldings- en opschortingsplicht voldoet. De dreiging van boetes kan lidstaten aanmoedigen hun verplichtingen nauwgezetter na te leven, hoewel daarmee geen afbreuk wordt gedaan aan de verplichting tot terugvordering bij de begunstigde van steun.

Begunstigden van onaangemelde steun zouden bij twijfel aan de belastingautoriteiten kunnen verzoeken om alsnog tot aanmelding van een steunmaatregel over te gaan. Desgewenst kan hij dit bij de nationale rechter afdwingen.

Aangezien slechts het door de subsidieontvanger genoten voordeel ongedaan gemaakt dient te worden om de vroegere competitieve situatie zo veel als mogelijk te herstellen, ben ik van mening dat bij de berekening van dat voordeel rekening dient te worden gehouden met eventuele geleden of te leiden schade als gevolg van de terugvordering van de subsidie (anders dan het subsidiebedrag zelf natuurlijk).

\section{Hoofdstuk 7}

Bij beantwoording van de vraag of sprake is van een gerechtvaardigd vertrouwen dient te worden nagegaan wie of wat tot een dergelijk vertrouwen aanleiding gaf. Nationale overheden en nationale wetgeving kunnen dit in beginsel niet, nu een dwingende bepaling van hogere orde de goedkeuring van steun expliciet opdraagt aan de Commissie. Hieraan ligt de veronderstelling ten grondslag dat tussen de nationale overheid en de begunstigde van steun in de regel een bepaalde mate van samenwerking bestaat en een gemeenschappelijk belang bij het verlenen van de steun. Verder is het de taak van de belastingadviseur zijn cliënt over mogelijke problemen met fiscale staatssteun tijdig te informeren. Zijn veronderstelde vaktechnische kennis van het staatssteunregime dient aan de belastingplichtige te worden toegerekend.

Terugvordering in de fiscale sfeer veronderstelt dat een eerdere belastingaanslag, waarin een onrechtmatig fiscaal voordeel is verwerkt, kan worden herzien. Alleen op deze wijze kan aan het verschuldigde bedrag aan belasting 
worden gewijzigd om een voordeel teniet te doen. Het Nederlandse fiscale procesrecht biedt daartoe de mogelijkheid tot navordering c.q. naheffing. Beiden zijn aan een vijfjaarslimiet gebonden; deze wordt effectief ter zijde gesteld door de tienjaarstermijn die de procedurele verordening stelt aan terugvordering. Nationale tijdslimieten kunnen namelijk niet aan terugvordering in de weg staan, aldus het Hof en het Gerecht. Voor wat betreft het vereiste van een nieuw feit ter zake van navordering, blijkt dat hieraan in beginsel niet zal zijn voldaan. De vraag stelt zich derhalve of dit vereiste terzijde moet worden geschoven om wijziging van de aanslag en daarmee terugvordering mogelijk te maken.

Naast de fiscale weg, kan getracht worden de civiele weg te bewandelen voor terugvordering. Het is niet nodig om fiscale staatssteun in de vorm van additionele belasting terug te vorderen; iedere andere vorm van betaling kan volstaan zolang daarmee de steun effectief wordt teruggevorderd. Zolang de aanslag echter in stand wordt gelaten, en daarmee de formele vaststelling van het verschuldigde bedrag, lijken vorderingen uit onverschuldigde betaling of ongerechtvaardigde verrijking weinig succesvol.

Naast terugvordering van het fiscale voordeel zelf, speelt ook nog de heffing van rente een rol. Fiscale procedures voorzien in het opleggen van heffings- en invorderingsrente, maar beide kunnen onvoldoende tegemoet komen aan de door de Commissie opgelegde verplichting tot het heffen van rente, mede gelet op het hogere rentetarief dat de Commissie doorgaans hanteert.

In deze studie stel ik voor om in Nederland een nieuwe, eenduidige fiscale procedure voor terugvordering in het leven te roepen als onderdeel van de Algemene wet inzake rijksbelastingen. Ik ben van mening dat, indien nationaal recht terugvordering niet toelaat, een lidstaat verplicht is een bruikbare procedure in het leven te roepen op grond van de algemene loyaliteitsverplichting die is vastgelegd in artikel $10 \mathrm{EG}$, gelezen in het licht van artikel 14 van de procedurele verordening dat ziet op terugvordering. Een afzonderlijke procedure lijkt te prefereren boven ad hoc oplossingen in individuele gevallen en kan tevens dienen als waarschuwing voor belastingplichtigen. Verder ben ik van mening dat fiscale steun, vanwege de bijzondere complexiteit en terminologie van het fiscale stelsel, een aparte procedure in de fiscale sfeer verdient in plaats van een overkoepelende procedure die ziet op alle vormen van overheidssteun.

De procedure dient onder meer te voorzien in het aanpassen van de belastingaanslag met het oog op terugvordering, een uniforme grondslag voor het heffen van rente naar Communautaire maatstaven en een verbod op uitstel dan wel afstel van terugvordering (behalve in gevallen waarin communautaire rechtsbeginselen hiertoe dwingen). Ten behoeve van de belastingplichtige kan voorzien worden in het herzien van definitieve belastingaanslagen met het oog op het alsnog opteren voor (rechtmatige) alternatieve fiscale faciliteiten in plaats van de teruggenomen, onrechtmatige faciliteit. Verder kan een bezwaarprocedure vaak worden overgeslagen, nu dit slechts een formaliteit is (de staat kan niet anders dan terugvorderen hoewel hij veelal de bezwaren van de belastingplichtige zal delen). Rechtstreeks beroep verdient derhalve de voorkeur. Verder dient de buitengerechtelijke afhandeling van schade door de nationale overheid te worden uitgesloten. Tot slot dient de belastingplichtige in de gelegenheid te worden gesteld 
om een verzoek tot aanmelding van een dubieuze fiscale faciliteit in te dienen bij de inspecteur, waarbij tegen een negatieve beschikking beroep openstaat. Gelijktijdig met dit verzoek dient de belastingplichtige in de gelegenheid te worden gesteld om toepassing van de faciliteit ten aanzien van hem op te schorten zonder daarmee zijn aanspraak op de faciliteit kwijt te raken (het 'voorwaardelijk opteren'). Een wettelijke verplichting tot het vermelden van een staatssteunvoorbehoud in aanslagen, met verwijzing naar relevante wetsbepalingen, acht ik, zoals gezegd, eveneens wenselijk.

Voor wat betreft het verzoek om aanmelding wordt in deze studie een voorstel gedaan om aan de belanghebbende rente te vergoeden indien de belastinginspecteur weigert tot aanmelding over te gaan en de begunstigde, vanwege zijn aanhoudende twijfel aan de rechtmatigheid van een fiscaal voordeel, er (vooralsnog) van afziet dit voordeel te genieten. Indien blijkt dat deze twijfel in beroep door een rechterlijke instantie wordt gedeeld, dan kan een rentevergoeding in bepaalde gevallen op zijn plaats zijn. Dit geldt ook in de onwaarschijnlijke situatie dat de inspecteur het met de begunstigde eens is en tot aanmelding laat overgaan, terwijl dit achteraf blijkt niet noodzakelijk te zijn geweest. Ik pleit ervoor dit verzoek een wettelijke grondslag te geven omdat een belastingplichtige baat heeft bij zekerheid, met name bij investerings- en vestigingsbeslissingen, ook al kan dit betekenen dat hij een (onrechtmatig) fiscaal voordeel uiteindelijk niet zal ontvangen.

\section{Hoofdstuk 8}

Tussen theorie en praktijk bestaat een wereld van verschil. Zo zullen concurrenten van steunontvangers in eerste instantie niet trachten aan hun tegenhangers steun te ontnemen, maar zij zullen eerder bij hun eigen (en wellicht dezelfde) overheid aankloppen voor (soortgelijke) steun. Begunstigden van fiscale steun zullen veelal niet stilstaan bij de staatssteunaspecten ervan, zolang anderen hen daar niet op wijzen. Hier lijkt een taak weggelegd voor hun belastingadviseurs.

Ook is het onwaarschijnlijk dat lidstaten bereid zullen zijn hun fiscale wetgeving zodanig aan te passen dat aan goedgekeurde buitenlandse steun geen afbreuk wordt gedaan, wanneer vanuit nationaal perspectief sprake is van oneigenlijk gebruik van dergelijke steun c.q. belastingontwijking. Evenmin blijken lidstaten bereid om van de wettelijke mogelijkheden gebruik te maken om de beschikking tot goedkeuring van omstreden fiscale steun aan te vechten.

Voor wat betreft terugvordering lijkt er slechts een pro forma uitzondering te bestaan door het gebruik van het ongedefinieerde begrip 'absolute onmogelijkheid'. Een nadere verduidelijking van dit begrip door de Europese gerechtshoven lijkt wenselijk. Eén vorm van onmogelijkheid, inbreuk op te beschermen gerechtvaardigd vertrouwen, is wel nadrukkelijk erkend maar de voorwaarden voor 'gerechtvaardigdheid' zijn zeer strikt en nauwelijks te verwezenlijken in het geval een begunstigde niet is nagegaan of de correcte procedure is gevolgd. Om onnodige procedures in ieder van de lidstaten te voorkomen stel ik voor om in de procedurele verordening te verduidelijken onder welke bijzondere omstandigheden 
terugvordering achterwege kan blijven, zodat dit onderwerp geheel bij de Europese gerechtshoven kan worden uitgeprocedeerd.

De verdere ontwikkeling van de WTO zal van belang zijn om het effect van het subsidieverdrag in de fiscale sfeer te bepalen. Druk van mede-WTO-lidstaten is noodzakelijk om staten tot verdragsconform handelen aan te zetten. Ik ben van mening dat handhaving van het Subsidieverdrag expliciet deel uit moet maken van de overwegingen van de Commissie in het kader van het staatssteunregime.

Fiscale steunmaatregelen die zijn vastgelegd in wet- en regelgeving zullen in de nabije toekomst niet de belangrijkste reden zijn voor bezorgdheid vanuit staatssteunperspectief, nu overheden steeds vaker experts bij het ontwerp ervan betrekken. Met name in de uitvoeringssfeer dient men beducht te zijn op staatssteun, vooral daar waar - abusievelijk - aan een belastingplichtige een fiscaal voordeel toekomt. De geheimhouding die hierbij een rol speelt maakt het voor de Commissie evenwel niet eenvoudig om hier een voet achter de deur te krijgen.

Met een vrije, interne markt tot doel kunnen de lidstaten niet zonder een staatssteunregime. Handhaving van dit regime kan op zijn beurt niet zonder de veronderstelling dat een begunstigde dient te controleren of de correcte procedure is gevolgd. Een toenemende transparantie en vereenvoudiging van staatssteunrichtlijnen kunnen hieraan bijdragen, tezamen met het voorgestelde verzoek om aanmelding en tijdelijke opschorting dat kan dienen om aan resterende twijfels een einde te maken.

Ten aanzien van de toekomstige invloed van het staatssteunregime op het terrein van belastingharmonisatie neem ik het standpunt in dat voor dit regime geen belangrijke rol is weggelegd. Weliswaar kan zij in de marge aan bepaalde bijzondere regimes een halt toeroepen, maar het regime zal de kern van de nationale fiscale stelsels niet substantieel beïnvloeden. 


\section{JURISPRUDENCE}

\section{Court of Justice of the European Communities}

\begin{tabular}{|c|c|c|c|c|}
\hline Number & Date & PARTIES & ECR & Paragraph \\
\hline $30 / 59$ & 23 February 1961 & $\begin{array}{l}\text { Gezamenlijke } \\
\text { Steenkolenmijnen } \\
\text { in Limburg v High } \\
\text { Authority of the } \\
\text { ECSC }\end{array}$ & 1961,1 & II.1.2.1, II.1.3.3 \\
\hline $25 / 62$ & 15 July 1963 & $\begin{array}{l}\text { Plaumann } v \\
\text { Commission }\end{array}$ & 1963,95 & II. 4.3 .2 \\
\hline $6 / 64$ & 15 July 1964 & Costa v E.N.E.L. & 1964,1141 & II.4.2.3 \\
\hline $\begin{array}{l}6 / 69 \\
11 / 69\end{array}$ & 10 December 1969 & $\begin{array}{l}\text { Commission } v \\
\text { France }\end{array}$ & 1969,523 & II.1.5.9 \\
\hline $47 / 69$ & 25 June 1970 & $\begin{array}{l}\text { France } v \\
\text { Commission }\end{array}$ & 1970,487 & II.1.1 \\
\hline $70 / 72$ & 12 July 1973 & $\begin{array}{l}\text { Commission v } \\
\text { Germany }\end{array}$ & 1973,81 & VI.1 \\
\hline $\begin{array}{l}21 / 72- \\
24 / 72\end{array}$ & 12 December 1972 & $\begin{array}{l}\text { International Fruit } \\
\text { Company } v \\
\text { Produktschap voor } \\
\text { Groenten en Fruit }\end{array}$ & 1972,1219 & V. 4.2 \\
\hline $77 / 72$ & 19 June 1973 & $\begin{array}{l}\text { Capolongo } v \\
\text { Azienda Agricole } \\
\text { Maya }\end{array}$ & 1973,611 & VI.6 \\
\hline $120 / 73$ & 11 December 1973 & $\begin{array}{l}\text { Lorenz } v \text { Germany } \\
\text { and Others }\end{array}$ & 1973,1471 & II. 4.2 .4 \\
\hline $173 / 73$ & 2 June 1974 & $\begin{array}{l}\text { Italy } v \\
\text { Commission }\end{array}$ & 1974,709 & $\begin{array}{l}\text { II.1.1, II.1.2.8, } \\
\text { II.1.4, II.1.5.2, } \\
\text { II.1.5.6 }\end{array}$ \\
\hline
\end{tabular}


Rewe-Zentral-

finanz and Others

$v$ Landwirtschafts-

kammer für das

Saarland

$78 / 76$

22 March 1977

Steinike-Weinlig

1977, 595

II.1.1

Germany

156/77 12 October 1978

Commission v

1978,1881

Belgium

61/79 27 March 1980

Amministrazione

1980, 1205

VI.3.4

delle finanze dello

Stato v Denkavit

Italiana

73/79 21 May 1980

Commission $v$

Italy

(Sovrapprezzo)

730/79 17 September 1980 Philip Morris

Holland $B V v$

Commission

104/81 26 October 1982

Hauptzollamt

Mainz v

Kupferberg

188/82 16 November 1983 Thyssen AGv $\begin{aligned} & \text { Then } \\ & \text { Commission }\end{aligned}$

1983,3721

VI.4.3

Amministrazione

1983, 3595

VI.2

delle Finanze dello

Stato $v$ San

Giorgio

205-215/82 21 September 1983 Deutsche

Milchkontor and

1987, $2633 \quad$ VI.4.1

Others $v$ Germany

117/83 15 September 1984

Konecke v Balm

1984, 3291

VI.5

Municipality of

1984,2889

II.4.3.2

Differdange and

Others $v$

Commission

52/84 15 January 1986

Commission v

1986,89

VI.3.1, VI.3.2

Belgium

169/84 28 June 1986

COFAZ and Oth-

1986,391

II.4.3.2

ers $v$ Commission

223/85 18 June 1987

Rijn-Schelde-

1987, $4617 \quad$ VI.4.3

Verolme Machine-

fabrieken en

Scheepswerven NV

$v$ Commission

265/85 11 March 1987

Van den Berg en

Jurgens $B V$ and

1987, 1155

VI.4.1, VI.4.3

Others v

Commission 


\begin{tabular}{|c|c|c|c|c|}
\hline $310 / 85$ & 24 February 1987 & $\begin{array}{l}\text { Deufil v } \\
\text { Commission }\end{array}$ & 1987,901 & II.1.3.2 \\
\hline $63 / 87$ & 7 June 1988 & $\begin{array}{l}\text { Commission v } \\
\text { Greece }\end{array}$ & 1988,2875 & VI.3.2 \\
\hline $70 / 87$ & 22 June 1989 & $\begin{array}{l}\text { Fediol } v \\
\text { Commission }\end{array}$ & 1989,1781 & V.4.2 \\
\hline $94 / 87$ & 2 February 1989 & $\begin{array}{l}\text { Commission v } \\
\text { Germany }\end{array}$ & 1990,175 & VI.2, VI.3.1 \\
\hline $102 / 87$ & 13 July 1988 & $\begin{array}{l}\text { France } v \\
\text { Commission }\end{array}$ & $1988, \mathrm{I}-4082$ & II.1.3.3, II.4.2.6 \\
\hline C-142/87 & 21 March 1990 & $\begin{array}{l}\text { Belgium } v \\
\text { Commission (Teu- } \\
\text { bemeuse) }\end{array}$ & 1990, I-959 & $\begin{array}{l}\text { II.1.4, II.3.2.1, } \\
\text { II.4.2.6, VI.1, VI.2, } \\
\text { VI.4.1, VII.3.1.2 }\end{array}$ \\
\hline $247 / 87$ & 14 February 1989 & $\begin{array}{l}\text { Star Fruit } \\
\text { Company } v \\
\text { Commission }\end{array}$ & 1989, 291 & VI.1 \\
\hline C-301/87 & 14 February 1990 & $\begin{array}{l}\text { France v Commis- } \\
\text { sion (Boussac) }\end{array}$ & $1990, \mathrm{I}-307$ & II.1.4, II.4.2.6 \\
\hline C-303/88 & 21 March 1991 & $\begin{array}{l}\text { Italy } v \\
\text { Commission } \\
\text { (ENI-Lanerossi) }\end{array}$ & $1991, \mathrm{I}-1433$ & II.1.4, II.3.2.1 \\
\hline C-5/89 & 20 September 1990 & $\begin{array}{l}\text { Commission v } \\
\text { Germany }\end{array}$ & $1990, \mathrm{I}-3437$ & $\begin{array}{l}\text { VI.2, VI.3.1, } \\
\text { VI.3.4, VI.4.1, } \\
\text { VII.2.2.3, VII.3.1.3 }\end{array}$ \\
\hline C-69/89 & 7 May 1991 & $\begin{array}{l}\text { Nakajima v } \\
\text { Council }\end{array}$ & 1991, I-2069 & V.4.2 \\
\hline C-172/89 & 12 December 1990 & $\begin{array}{l}\text { Vandemoortele NV } \\
v \text { Commission }\end{array}$ & $1990, \mathrm{I}-4677$ & VI.5 \\
\hline C-305/89 & 21 March 1991 & $\begin{array}{l}\text { Italy } v \\
\text { Commission }\end{array}$ & $1991, \mathrm{I}-1603$ & II.4.2.6 \\
\hline C-313/90 & 24 March 1993 & $\begin{array}{l}\text { CIRFS v } \\
\text { Commission }\end{array}$ & $1993, \mathrm{I}-1125$ & II.4.3.1, II.4.3.2 \\
\hline C-354/90 & 21 November 1991 & $\begin{array}{l}\text { FNCP and Syndi- } \\
\text { cat National des } \\
\text { Negociants et } \\
\text { Transformateurs } \\
\text { de Saumon } v \\
\text { France }\end{array}$ & 1991, I-5505 & VII.3.1.2 \\
\hline C-358/90R & 19 December 1990 & $\begin{array}{l}\text { Compagnia ital- } \\
\text { iana alcool Sas di } \\
\text { Mario Mariano } \mathcal{E} \\
\text { Co. } v \text { Commission }\end{array}$ & $1990, \mathrm{I}-4887$ & VI.7 \\
\hline$C-47 / 91$ & 5 October 1994 & $\begin{array}{l}\text { Italy } v \\
\text { Commission }\end{array}$ & $1994, \mathrm{I}-4635$ & II.4.2.2 \\
\hline $\begin{array}{l}\text { C-72/91, } \\
\text { C-73/91 }\end{array}$ & 17 March 1993 & $\begin{array}{l}\text { Sloman Neptun v } \\
\text { Seebetriebsrat }\end{array}$ & $1993, \mathrm{I}-887$ & $\begin{array}{l}\text { II.1.3.2, II.1.5.6, } \\
\text { II.1.5.11 }\end{array}$ \\
\hline C-183/91 & 10 June 1993 & $\begin{array}{l}\text { Commission v } \\
\text { Greece }\end{array}$ & $1993, \mathrm{I}-3131$ & $\begin{array}{l}\text { VI.2, VI.3.1, } \\
\text { VI.3.4, VI.4.1, } \\
\text { VII.3.2 }\end{array}$ \\
\hline
\end{tabular}




\begin{tabular}{|c|c|c|c|c|}
\hline C-198/91 & 19 May 1993 & $\begin{array}{l}\text { Cook } v \\
\text { Commission }\end{array}$ & $1993, \mathrm{I}-2487$ & II.4.3.2 \\
\hline C-225/91 & 15 June 1993 & $\begin{array}{l}\text { Matra v } \\
\text { Commission }\end{array}$ & $1993, \mathrm{I}-3203$ & $\begin{array}{l}\text { II. } 4.3 .2 \text {, II.4.3.3, } \\
\text { III. } 3\end{array}$ \\
\hline C-188/92 & 9 March 1994 & $\begin{array}{l}\text { Textilwerke } \\
\text { Deggendorf } \mathrm{GmbH} \\
v \text { Germany }\end{array}$ & $1994, \mathrm{I}-833$ & VI.3.4 \\
\hline $\begin{array}{l}\text { C-278/92 - } \\
\text { C-280/92 }\end{array}$ & 14 September 1994 & $\begin{array}{l}\text { Spain } v \\
\text { Commission }\end{array}$ & $1994, \mathrm{I}-4103$ & $\begin{array}{l}\text { II.3.2.1, II.4.3.3, } \\
\text { VI.4.1 }\end{array}$ \\
\hline C-387/92 & 15 March 1994 & $\begin{array}{l}\text { Banco Exterio de } \\
\text { Espãna }\end{array}$ & $1994, \mathrm{I}-877$ & II.1.2.1 \\
\hline C-280/93 & 5 October 1994 & $\begin{array}{l}\text { Germany } v \\
\text { Council }\end{array}$ & $1994, \mathrm{I}-4973$ & V.4.2 \\
\hline C-349/93 & 23 February 1995 & $\begin{array}{l}\text { Commission v } \\
\text { Italy }\end{array}$ & $1995, \mathrm{I}-343$ & VI.3.1, VI.3.2 \\
\hline $\begin{array}{l}\text { Opinion } \\
1 / 94^{1}\end{array}$ & 15 November 1994 & & $1994, \mathrm{I}-5267$ & V.2 \\
\hline C-39/94 & 11 July 1996 & $\begin{array}{l}\text { SFEI and Others } v \\
\text { La Poste a.o }\end{array}$ & 1996, I-3547 & II.4.3.1, VI.4.3 \\
\hline C-122/94 & 29 February 1996 & $\begin{array}{l}\text { Commission v } \\
\text { Council }\end{array}$ & $1996, \mathrm{I}-881$ & II. 2.4, II. 4.3 .3 \\
\hline C-241/94 & 26 September 1996 & $\begin{array}{l}\text { France v Commis- } \\
\text { sion (Kimberly } \\
\text { Clark Sopalin) }\end{array}$ & 1996, I-4551 & II.1.5.3 \\
\hline C-24/95 & 20 March 1997 & $\begin{array}{l}\text { Land Rheinland- } \\
\text { Pfalz v Alcan } \\
\text { Deutschland }\end{array}$ & 1997, I-1591 & $\begin{array}{l}\text { VI.3.2, VI.4.1, } \\
\text { VII.3.1.3 }\end{array}$ \\
\hline C-169/95 & 14 January 1997 & $\begin{array}{l}\text { Spain } v \\
\text { Commission }\end{array}$ & 1997, I-135 & $\begin{array}{l}\text { H.4.3.3, VI.1, } \\
\text { VI.4.1, VI.4.4 }\end{array}$ \\
\hline C-280/95 & 29 January 1998 & $\begin{array}{l}\text { Commission v } \\
\text { Italy }\end{array}$ & 1998, I-259 & VI.3.1, VI.3.3 \\
\hline C-355/95P & 15 May 1997 & $\begin{array}{l}\text { Textilwerke } \\
\text { Deggendorf } v \\
\text { Commission }\end{array}$ & 1997, I-2549 & II.4.2.6 \\
\hline C-367/95P & 2 April 1998, & $\begin{array}{l}\text { Commission v } \\
\text { Sytraval }\end{array}$ & $1998, \mathrm{I}-1710$ & II.4.3.2 \\
\hline C-149/96 & 23 November 1999 & Portugal v Council & 1999, I-8395 & V.4.2 \\
\hline C-264/96 & 16 July 1998 & ICI $v$ Colmer & $1998, \mathrm{I}-4695$ & II.1.1 \\
\hline C-342/96 & 29 April 1999 & $\begin{array}{l}\text { Spain v Commis- } \\
\text { sion (Tubacex) }\end{array}$ & 1999, I-2459 & II.1.2.3 \\
\hline$C-6 / 97$ & 19 May 1999 & $\begin{array}{l}\text { Italy } v \\
\text { Commission }\end{array}$ & 1999, I-2981 & $\begin{array}{l}\text { II.1.2.1, VI.3.1, } \\
\text { VI.3.3 }\end{array}$ \\
\hline C-75/97 & 17 June 1999 & $\begin{array}{l}\text { Belgium } v \\
\text { Commission } \\
\text { (Maribel bis/ter) }\end{array}$ & 1999, I-3671 & $\begin{array}{l}\text { II.1.5.2, II.1.5.6, } \\
\text { VI.5, VI.7 }\end{array}$ \\
\hline
\end{tabular}




\begin{tabular}{|c|c|c|c|c|}
\hline C-95/97 & 21 March 1997 & $\begin{array}{l}\text { Region Wallone v } \\
\text { Commission }\end{array}$ & 1997, I-1787 & II.4.3.2 \\
\hline C-200/97 & 1 December 1998 & Ecotrade $v$ AFS & $1998, \mathrm{I}-7907$ & II.1.2.1, II.1.5.11 \\
\hline C-204/97 & 3 May 2001 & $\begin{array}{l}\text { Portugal } v \\
\text { Commission }\end{array}$ & 2001, I-3175, & II. 4.2 .4 \\
\hline C-256/97 & 29 June 1999 & $D M T$ & $1999, \mathrm{I}-3913$ & II.1.2.3, II.1.5.3 \\
\hline C-295/97 & 17 June 1999 & $\begin{array}{l}\text { Piaggio v Ifitalia } \\
\text { and Others }\end{array}$ & 1999, I-3735 & II.4.3.1, VI.4.3 \\
\hline $\begin{array}{l}C-400 / 97 \text { - } \\
C-402 / 97\end{array}$ & 16 February $2000^{2}$ & $\begin{array}{l}\text { Administración } \\
\text { General del Estado } \\
\text { v Juntas Generales } \\
\text { de Guipúzcoa et } \\
\text { Diputación Foral } \\
\text { de Guipúzcoa }\end{array}$ & $2000, \mathrm{I}-1073$ & II.1.5.8 \\
\hline$C-404 / 97$ & 27 June 2000 & $\begin{array}{l}\text { Commission v } \\
\text { Portugal }\end{array}$ & $2000, \mathrm{I}-4897$ & $\begin{array}{l}\text { VI.3.1, VI.3.2, } \\
\text { VI.4.1 }\end{array}$ \\
\hline $\begin{array}{l}\text { C-15/98, } \\
\text { C-105/99 }\end{array}$ & 19 October 2000 & $\begin{array}{l}\text { Italy and Sardegna } \\
\text { Lines } v \\
\text { Commission }\end{array}$ & $2000, \mathrm{I}-8855$ & II. 4.3 .2 \\
\hline C-83/98P & 16 May 2000 & $\begin{array}{l}\text { France } v \text { Ladbroke } \\
\text { Racing and } \\
\text { Commission }\end{array}$ & $2000, \mathrm{I}-3271$ & $\begin{array}{l}\text { II.1.1, II.3.2.1, } \\
\text { II.4.3.3, VI.4.1, } \\
\text { VI.4.3. }\end{array}$ \\
\hline C-99/98 & 15 February 2001 & $\begin{array}{l}\text { Austria v } \\
\text { Commission }\end{array}$ & 2001, I-1101 & II. 4.2 .4 \\
\hline C-156/98 & 19 September 2000 & $\begin{array}{l}\text { Germany } v \\
\text { Commission }\end{array}$ & $2000, \mathrm{I}-6857$ & $\begin{array}{l}\text { II.1.3.3, II.2.2, } \\
\text { II. } 3.2 .1, \text { III.3 }\end{array}$ \\
\hline C-332/98 & 22 June 2000 & $\begin{array}{l}\text { France v Commis- } \\
\text { sion (CELF) }\end{array}$ & 2000, I-4833 & II. 4.2 .3 \\
\hline C-378/98 & 3 July 2001 & $\begin{array}{l}\text { Commission } v \\
\text { Belgium } \\
\text { (Maribel bis/ter) }\end{array}$ & 2001, I-5107 & VI.3.3, VI.7 \\
\hline C-379/98 & 13 March 2001 & $\begin{array}{l}\text { PreussenElektra v } \\
\text { Sleswag }\end{array}$ & 2001, I-2099 & II.1.3.1, II.1.3.2 \\
\hline $\begin{array}{l}\text { C-397/98, } \\
\text { C-410/98 }\end{array}$ & 8 March 2001 & $\begin{array}{l}\text { Metallgesellschaft / } \\
\text { Hoechst } v \text { Com- } \\
\text { missioners of } \\
\text { Inland Revenue } \\
\text { and HM A-G }\end{array}$ & 2001, I-1727 & VI.2 \\
\hline C-480/98 & 12 October 2000 & $\begin{array}{l}\text { Spain v Commis- } \\
\text { sion (Magefesa) }\end{array}$ & $2000, \mathrm{I}-8717$ & II.1.2.5, II.4.2.6 \\
\hline C-143/99 & 8 November 2001 & $\begin{array}{l}\text { Adria-Wien Pipe- } \\
\text { line and Others } v \\
\text { Finanzlandes- } \\
\text { direktion für } \\
\text { Kärnten }\end{array}$ & 2001, I-8365 & II.1.5.2 \\
\hline
\end{tabular}

2 This is the release date of the Opinion of the A-G that has been discussed in this thesis. The case itself has not been decided upon by the ECJ; it was removed from its register. 


\begin{tabular}{|c|c|c|c|c|}
\hline C-261/99 & 22 March 2001 & $\begin{array}{l}\text { Commission } v \\
\text { France }\end{array}$ & $2001, \mathrm{I}-2537$ & VI.3.1 \\
\hline C-321/99P & 16 May 2002 & $\begin{array}{l}\text { ARAP and Others } \\
v \text { Commission }\end{array}$ & $\begin{array}{l}\text { not yet } \\
\text { published }\end{array}$ & II. 4.2 .2 \\
\hline C-382/99 & 13 June 2002 & $\begin{array}{l}\text { The Netherlands } v \\
\text { Commission }\end{array}$ & $\begin{array}{l}\text { not yet } \\
\text { published }\end{array}$ & $\begin{array}{l}\text { II.1.3.2, II.3.2.2, } \\
\text { II.4.2.6, II.4.3.3, } \\
\text { VI.1, VI.2, VI.3.3 }\end{array}$ \\
\hline C-400/99 & 9 October 2001 & $\begin{array}{l}\text { Italy } v \text { Commis- } \\
\text { sion (Tirrenia) }\end{array}$ & 2001, I-7303 & $\begin{array}{l}\text { II. } 4.1, \text { II.4.2.4, } \\
\text { II. } 4.3 .3\end{array}$ \\
\hline C-499/99 & 2 July 2002 & $\begin{array}{l}\text { Commission v } \\
\text { Spain }\end{array}$ & $\begin{array}{l}\text { not yet } \\
\text { published }\end{array}$ & VI.3.2 \\
\hline C-53/00 & 22 November 2001 & Ferring $v$ ACOSS & 2001, I-9067 & $\begin{array}{l}\text { II.1.2.1, II.1.2.9, } \\
\text { II.1.5.2 }\end{array}$ \\
\hline
\end{tabular}

\section{Court of First Instance}

$\begin{array}{llll}\text { Number Date } & \text { Parties } & \text { ERagraph }\end{array}$

\begin{tabular}{|c|c|c|c|c|}
\hline $\begin{array}{l}\text { T-244/93, } \\
\text { T-486/93 }\end{array}$ & 13 September 1995 & $\begin{array}{l}\text { Textilwerke } \\
\text { Deggendorf } v \\
\text { Commission }\end{array}$ & 1995, II-2265 & II.4.2.6, VII.3.1.3 \\
\hline $\begin{array}{l}\text { T-447/93 - } \\
\mathrm{T}-449 / 93\end{array}$ & 6 July 1995 & $\begin{array}{l}\text { Aitec and Others } v \\
\text { Commission }\end{array}$ & 1995, II-1971 & II.4.3.2 \\
\hline $\mathrm{T}-459 / 93$ & 8 June 1995 & $\begin{array}{l}\text { Siemens v } \\
\text { Commission }\end{array}$ & 1995, II-1675 & II.4.2.6, VI.3.1 \\
\hline T-67/94 & 27 January 1998 & $\begin{array}{l}\text { Ladbroke Racing } v \\
\text { Commission }\end{array}$ & 1998, II-1 & $\begin{array}{l}\text { II.1.1, II.1.2.1, } \\
\text { II.1.5.7, II.3.2.1, } \\
\text { II.4.2.6, II.4.3.3, } \\
\text { VI.4.1 }\end{array}$ \\
\hline T-277/94 & 22 May 1996 & $\begin{array}{l}\text { AITEC } v \\
\text { Commission }\end{array}$ & 1996, II-351 & VI.1 \\
\hline T-6/95R & 15 March 1995 & $\begin{array}{l}\text { Cantine dei Colli } \\
\text { Berici Coop. ARL v } \\
\text { Commission }\end{array}$ & 1995, II-647 & VI.7 \\
\hline T-11/95 & 15 September 1998 & $\begin{array}{l}\text { BP Chemicals } v \\
\text { Commission }\end{array}$ & 1998, II-3235 & II.4.3.2 \\
\hline T-106/95 & 27 February 1997 & $\begin{array}{l}\text { FFSA and Others } \\
v \text { Commission }\end{array}$ & 1997, II-229 & II.1.2.9 \\
\hline T-149/95 & 5 November 1997 & $\begin{array}{l}\text { Ducros v } \\
\text { Commission }\end{array}$ & 1997, II-2031 & VI.4.3 \\
\hline T-214/95 & 30 April 1998 & $\begin{array}{l}\text { Vlaams Gewest v } \\
\text { Commission }\end{array}$ & 1998, II-717 & $\begin{array}{l}\text { II.1.4, II.3.2.1, } \\
\text { II.4.2.6, II.4.3.2 }\end{array}$ \\
\hline T-86/96 & 11 February 1999 & $\begin{array}{l}\text { ADL and } \\
\text { Happag-Lloyd } \\
\text { Fluggesellschaft } v \\
\text { Commission }\end{array}$ & 1999, II-179 & II.4.3.2 \\
\hline
\end{tabular}




\begin{tabular}{|c|c|c|c|c|}
\hline T-95/96 & 15 September 1998 & $\begin{array}{l}\text { Gestevision } \\
\text { Telecinco v } \\
\text { Commission }\end{array}$ & 1998, II-3407 & II. 4.2 .6 \\
\hline T-288/97 & 4 April 2001 & $\begin{array}{l}\text { Regio Autonoma } \\
\text { Fruili-Venezia } \\
\text { Giulia v } \\
\text { Commission }\end{array}$ & 2001, II-1169 & II.1.4, II.4.3.3 \\
\hline T-298/973 & 15 June 2000 & $\begin{array}{l}\text { Mauro Alzetta et } \\
\text { al. } v \text { Commission }\end{array}$ & 2000, II-2319 & VI.1 \\
\hline T-613/97 & 14 December 2000 & $\begin{array}{l}\text { Ufex and Others } v \\
\text { Commission }\end{array}$ & 2000, II-4055 & II.1.3.5 \\
\hline T-9/98 & 22 November 2001 & $\begin{array}{l}\text { Mitteldeutsche } \\
\text { Erdöl-Raffinerie v } \\
\text { Commission }\end{array}$ & 2001, II-3367 & II. 4.3 .2 \\
\hline T-55/99 & 29 September 2000 & $\begin{array}{l}\text { Confederación } \\
\text { Española de Trans- } \\
\text { porte de Mer- } \\
\text { cancías (CETM) v } \\
\text { Commission }\end{array}$ & 2000, II-3207 & $\begin{array}{l}\text { II.1.4, II.3.2.1, } \\
\text { VI.4.3 }\end{array}$ \\
\hline $\begin{array}{l}\text { T-127/99, } \\
\text { T-129/99, } \\
\text { T-148/99 }\end{array}$ & 6 March 2002 & $\begin{array}{l}\text { Territorio } \\
\text { Histórico de Álava } \\
\text { and Others } v \\
\text { Commission }\end{array}$ & $\begin{array}{l}\text { not yet } \\
\text { published }\end{array}$ & VI.4.1 \\
\hline $\begin{array}{l}\text { T-92/00, } \\
\text { T-103/00 }\end{array}$ & 6 March 2002 & $\begin{array}{l}\text { Territorio } \\
\text { Histórico de Álava } \\
\text { and Others v } \\
\text { Commission } \\
\text { (Ramondin) }\end{array}$ & $\begin{array}{l}\text { not yet } \\
\text { published }\end{array}$ & $\begin{array}{l}\text { II.1.3.2, II.1.5.2, } \\
\text { II.1.5.3, II.1.5.5, } \\
\text { II.1.5.6, II.1.5.8, } \\
\text { II.1.5.12, II.3.2.1, } \\
\text { III.1.2, VI.4.1 }\end{array}$ \\
\hline $\begin{array}{l}\text { T-195/01R } \\
\text { T-207/01R }\end{array}$ & 19 December 2001 & $\begin{array}{l}\text { Gibraltar } v \text { Com- } \\
\text { mission }\end{array}$ & 2001, II-3915 & $\begin{array}{l}\text { II.4.2.2, II.4.2.4, } \\
\text { II.4.3.1, II.4.3.3, } \\
\text { III.1.3, VI.7 }\end{array}$ \\
\hline $\begin{array}{l}\text { T-195/01, } \\
\text { T-207/01 }\end{array}$ & 30 April 2002 & $\begin{array}{l}\text { Gibraltar } v \text { Com- } \\
\text { mission }\end{array}$ & $\begin{array}{l}\text { not yet } \\
\text { published }\end{array}$ & $\begin{array}{l}\text { II.1.4, I.4.2.2, } \\
\text { II.4.3.3, III.1.2, } \\
\text { VI. } 4.3\end{array}$ \\
\hline
\end{tabular}




\section{National Courts}

\begin{tabular}{|c|c|c|c|}
\hline Court & Date & Location & Paragrapl \\
\hline $\begin{array}{l}\text { Afdeling rechtspraak Raad } \\
\text { van State }(\mathrm{NL})\end{array}$ & 30 June 1992 & АВ $1993 / 447$ & VII.3.3 \\
\hline $\begin{array}{l}\text { Afdeling bestuursrecht- } \\
\text { spraak (NL) }\end{array}$ & 21 October 1996 & AB 1996/496 & VII.3.2 \\
\hline $\begin{array}{l}\text { Afdeling bestuursrecht- } \\
\text { spraak (NL) }\end{array}$ & 26 August 1997 & АВ $1997 / 461$ & VII.3.2 \\
\hline $\begin{array}{l}\text { Bundesverfassungs- } \\
\text { gericht }(G)\end{array}$ & 17 February 2000 & BvR 1210/98 & VI.4.1 \\
\hline $\begin{array}{l}\text { Bundesverwaltungs- } \\
\text { gericht }(G)\end{array}$ & 17 February 1993 & $\begin{array}{l}\text { BverwGE } \\
92,81\end{array}$ & VI.4.1 \\
\hline Corte costituzionale (I) & 9 April 1963 & $\begin{array}{l}\text { Foro italiano, } \\
\text { no. } 49,1963 \text {, } \\
\text { I, } 859\end{array}$ & VII.3.1.2 \\
\hline Corte costituzionale (I) & 8 July 1969 & $\begin{array}{l}\text { Foro italiano, } \\
\text { no. 120, 1969, } \\
\text { I, } 2069\end{array}$ & VII.3.1.2 \\
\hline Österreichischer & & See Opinion & VII.3.1.2 \\
\hline Verfassungsgerichtshof (A) & & $\begin{array}{l}\text { A-G in ECJ } \\
C-143 / 99\end{array}$ & \\
\hline Gerechtshof Arnhem (NL) & 4 February 1993 & NJ $1993 / 789$ & VII.3.1.4 \\
\hline Hoge Raad (NL) & 26 September 1979 & AB $1980 / 210$ & VII.2.2.2 \\
\hline Hoge Raad (NL) & 11 June 1997 & $\begin{array}{l}\text { BNB } \\
1997 / 384\end{array}$ & VII.3.1.4 \\
\hline Hoge Raad (NL) & 12 September 1997 & NJ 1998/145 & VII.3.1.4 \\
\hline Hoge Raad (NL) & 7 November 1997 & AB $1998 / 221$ & VII. 3.5 \\
\hline Hoge Raad (NL) & 8 May 1998 & $\begin{array}{l}\text { BNB } \\
1998 / 277 c^{*}\end{array}$ & VII.3.3 \\
\hline Hoge Raad (NL) & 12 May 1999 & $\begin{array}{l}\text { BNB } \\
1999 / 258\end{array}$ & VII.3.1.4 \\
\hline
\end{tabular}

\section{WTO Panel Reports}

\section{Case}

United States - Income tax legislation (DISC)

Income tax practices maintained by Belgium

Income tax practices maintained by France

Income tax practices maintained by The Netherlands

\section{Date of Adoption Document Paragraph}

2 November $1976 \quad$ L/4422 $\quad$ IV.5.1

2 November $1976 \quad$ L/4423 IV.5.1

2 November $1976 \quad$ L/4424 IV.5.1

2 November $1976 \quad$ L/4425 IV.5.1 


\begin{tabular}{|c|c|c|c|}
\hline $\begin{array}{l}\text { Brazil - Export Financing } \\
\text { Programme for Aircraft }\end{array}$ & 20 August 1999 & $\begin{array}{l}\text { WT/DS46/ } \\
\text { R }\end{array}$ & $\begin{array}{l}\text { IV.2, IV.3.2.5, } \\
\text { IV. } 8\end{array}$ \\
\hline $\begin{array}{l}\text { Brazil - Export Financing } \\
\text { Programme for Aircraft } \\
\text { (Recourse by Canada to Article } \\
21.5 \text { DSU) }\end{array}$ & 4 August 2000 & $\begin{array}{l}\text { WT/DS46/ } \\
\text { RW }\end{array}$ & IV.3.2.1 \\
\hline $\begin{array}{l}\text { Canada - Measures Affecting } \\
\text { the Export of Civilian Aircraft }\end{array}$ & 20 August 1999 & $\begin{array}{l}\text { WT/DS70/ } \\
\text { R }\end{array}$ & IV. 2 \\
\hline $\begin{array}{l}\text { United States - Tax Treatment } \\
\text { For "Foreign Sales Corpora- } \\
\text { tions" }\end{array}$ & 20 March 2000 & $\begin{array}{l}\text { WT/DS108/ } \\
\text { R }\end{array}$ & IV.5.2.2, IV.5.2.3 \\
\hline $\begin{array}{l}\text { United States - Tax Treatment } \\
\text { For "Foreign Sales Corpora- } \\
\text { tions" (Recourse to Article } \\
21.5 \text { DSU) }\end{array}$ & 29 January 2002 & $\begin{array}{l}\text { WT/DS/108/ } \\
\text { RW }\end{array}$ & IV.5.2.5 \\
\hline $\begin{array}{l}\text { Australia - Subsidies provided } \\
\text { to Producers and Exporters of } \\
\text { Automotive Leather }\end{array}$ & 16 June 1999 & $\begin{array}{l}\text { WT/DS/126/ } \\
\text { R }\end{array}$ & IV.4.2 \\
\hline $\begin{array}{l}\text { Australia - Subsidies provided } \\
\text { to Producers and Exporters of } \\
\text { Automotive Leather } \\
\text { (Recourse to Article } 21.5 \text { of the } \\
\text { DSU by the United States) }\end{array}$ & 11 February 2000 & $\begin{array}{l}\text { WT/DS/126/ } \\
\text { RW }\end{array}$ & IV.4.2, V.5.5 \\
\hline $\begin{array}{l}\text { United States - Imposition } \\
\text { of Countervailing Duties on } \\
\text { Certain Hot-Rolled Lead } \\
\text { and Bismuth Carbon Steel } \\
\text { Products Originating in the } \\
\text { United Kingdom }\end{array}$ & 7 June 2000 & $\begin{array}{l}\text { WT/DS138/ } \\
\text { R }\end{array}$ & IV.6.1 \\
\hline $\begin{array}{l}\text { United States - Measures } \\
\text { Treating Exports Restraints }\end{array}$ & 23 August 2001 & $\begin{array}{l}\text { WT/DS194/ } \\
\text { R }\end{array}$ & IV. 2 \\
\hline
\end{tabular}

As Subsidies

\section{WTO Appellate Body Reports}

\section{Case}

Brazil - Measures Affecting

Desiccated Coconut

Brazil - Export Financing

Programme for Aircraft

Canada-Measures Affecting

the Export of Civilian Aircraft

Canada - Measures Affecting

the Export of Civilian Aircraft

(Recourse by Brazil to Article

21.5 of the DSU)
Date of Adoption

20 March 1997

20 August 1999

20 August 1999

4 August 2000

\section{Document Paragraph}

WT/DS22/ IV.6.1

$\mathrm{AB} / \mathrm{R}$

WT/DS46/ IV.2, IV.3.2.5

$\mathrm{AB} / \mathrm{R}$

WT/DS70/ IV.2, IV.3.2.1

$\mathrm{AB} / \mathrm{R}$

WT/DS70/

$\mathrm{AB} / \mathrm{RW}$ 
United States - Tax Treatment 20 March 2000

For "Foreign Sales Corpora-

tions"

United States -

Tax Treatment For "Foreign

Sales Corporations" (Recourse

to Article 21.5 DSU)

United States - Imposition of

Countervailing Duties on

Certain Hot-Rolled Lead

and Bismuth Carbon Steel

Products Originating in the

United Kingdom

Canada-Measures Affecting 19 June 2000

the Automotive Industry

United States -

Safeguard Measures on

Imports of Fresh, Chilled or

Frozen Lamb Meat From New

Zealand and Australia

7 June 2000

16 May 2001
29 January 2002

WT/DS138/ IV.7.1

$\mathrm{AB} / \mathrm{R}$

WT/DS139/

IV.3.2.1, IV.3.2.2

$\mathrm{AB} / \mathrm{R}$

WT/DS142/

$\mathrm{AB} / \mathrm{R}$

WT/DS177/

$\mathrm{AB} / \mathrm{R}$

WT/DS178/

$\mathrm{AB} / \mathrm{R}$

WT/DS/108/ IV.5.2.6

$\mathrm{AB} / \mathrm{RW}$

\section{WTO Arbitration Decisions}

Case

Brazil - Export Financing

Programme for Aircraft

(Recourse to Arbitration by

Brazil under Article 22.6 of the

DSU and Article 4.11 of the

SCM Agreement)

United States - Tax Treatment

For "Foreign Sales Corpora-

tions" (Recourse to Arbitration by the United States

under Article 22.6 of the DSU and Article 4.11 of the SCM

Agreement)
Date of Circulation

28 August 2000

30 August 2002

WT/DS108/

ARB
WT/DS46/

ARB
Paragraph

IV.3.2.3, IV.5.2.7

WT/DS108/ IV.5.2.2, IV.5.2.3
AB/R 


\section{BIBLIOGRAPHY}

Arnold, A.J., Dibout, P. (2001), General Report, in: Limits on the use of low-tax regimes by multinational businesses: current measures and emerging trends, Cahiers de droit fiscal international, vol. LXXXVIb, pp. 21-89

Avi-Yonah, R.S. (2000), Tax, Trade and Harmful Tax Competition: Reflections on the FSC Controversy, Tax Notes International, vol. 21, 18 December 2000, pp. 2841-2845

Avi-Yonah, R.S. (2001), Treating Tax Issues Through Trade Regimes, Brooklyn Journal of International Law, vol. 26, pp. 1683-1692

Bacon, K. (1998), State Aids and General Measures, in: Barav, A., Wyatt, D.A. (eds.), Yearbook of European Law, vol. 17, pp. 269-321

Bacon, K. (1999), Differential Taxes, State Aids and the Lunn Poly Case, European Competition Law Review, no. 7, pp. 384-391

Bardenhewer, F. (1995), Effektive Durchsetzung des europäischen Gemeinschaftsrechts und nationaler Vertrauensschutz, in: Grawert / Schlink / Wahl / Wieland (eds.), Offene Staatlichkeit, Berlin: Duncker \& Humblot, pp. $242 \mathrm{ff}$

Benitah, M. (2001), The Law of Subsidies under the GATTMTO System, The Hague: Kluwer Bleckmann, A. (1984), Subventionsprobleme des GATT und der EG: Ordnungsrahmen für das recht der Subventionen - Internationaler Teil, Rabels Zeitschrift für ausländisches und internationales Privatrecht, vol. 48, pp. 419-456

Bollen, C. (1999), Verknoeit het Europese recht ook ons bestuursrecht?, in: Heldeweg M.A., Van der Linden, E.C.H.J., Schlössels, R.J.N. (eds.), Uit de School geklapt?, The Hague: Sdu, pp. 39-63

Bourgeois, J.H.J. (1999), State Aids, Taxation Measures and Specificity. Some Thoughts in: Dony, M. (ed.), Mélanges en hommage à Michel Waelbroek, Brussels: Bruylant, pp. 765776

Buss, T.F. (2001), The Effect of State Tax Incentives on Economic Growth and Firm Location Decisions: An Overview of the Literature, Economic development quarterly, vol. 15, no. 1, pp. $90-105$

Clark, H.R., Bogran, A., Hanson, L. (2001), The WTO Ruling on Foreign Sales Corporations: Costliest Battle Yet in an Escalating Trade War Between the United States and the European Union?, Minnesota Journal of Global Trade, vol. 10, pp. 291-321

Cottier, T. (1998), Dispute Settlement in the World Trade Organization: Characteristics and Structural Implications for the European Union, Common Market Law Review, vol. 35, pp. 325-378 
De Hosson, F.C. (1996a), Bijzondere fiscale regimes en het communautaire recht, Weekblad fiscaal recht, no. 6208, pp. 1111-1136

De Hosson, F.C. (1996b), The neighbour is a beggar, Weekblad fiscaal recht, no. 6225, pp. 1858-1866

De Hosson, F.C. (1997), introductory speech in: Fiscale concurrentie en Europees monetair beleid, Geschriften van de Vereniging voor Belastingwetenschap, no. 205, Deventer: Kluwer

Demaret, P., Stewardson, R. (1994), Border Tax Adjustments under GATT and EC Law and General Implications for Environmental Taxes, Journal of World trade, vol. 28, no. 4, pp. 5-65 Desai, M.A., Hines Jr., J.R. (2000), The Uneasy Marriage of Export Incentives and The Income Tax, in: NBER Working Paper Series (National Bureau of Economic Research), no. 8009, Cambridge, Massachusetts

Desmedt, A. (2000), European Court of Justice on the Effect of WTO Agreements in the EC Legal Order, Journal of Economic Integration, vol. 27, no. 1, pp. 93-101

Didier, P. (1999), WTO Trade Instruments in EU Law, London: Cameron May

Easson, A. (2001a), Tax Incentives for Foreign Direct Investment, Bulletin for international fiscal documentation, July 2001, pp. 266-274 (part I), August 2001, pp. 365-375 (part II)

Easson, A. (2001b), State Aid and the Primarolo List, The EC Tax Journal, vol. 5, no. 2, pp. 109-125

Engelen, F.A. (1999), Belastingconcurrentie binnen de EU. Over fiscale beleidsconcurrentie, fiscale marktdistorties en fiscale staatssteun, Nederlands tijdschrift voor Europees recht, no. 1, 19-31

Evans, A. (1997), EC Law of State Aid, Oxford: Clarendon Press

Feldstein, M. (1980), A Contribution to the Theory of Tax Expenditures: The Case of Charitable Giving, in: Aaron, H.J, Boskin, M.J. (eds.), The Economics of Taxation, Washington D.C.: The Brookings Institution, pp. 99-122

Fischer-Zernin, J. (1989), GATT versus tax treaties? The basic conflicts between international taxation methods and the rules and concepts of GATT, Intertax, no. 6, pp. 236-245 (part I), no. 7, pp. 310-315 (part II)

Frick, K.A. (1994), Einkommensteuerliche Steuervergünstigungen und Beihilfeverbot nach dem EG-Vertrag, Sinzheim: Pro Universitate Verlag

Götz, V. (2000), Steuervergünstigungen als Gegenstand der europäischen Beihilfenaufsicht, in: Kirchhof, P., Lehner, M., Raupach, A., Rodi, M., Staaten und Steuern - Festschrift für Klaus Vogel zum 70. Geburtstag, Heidelberg: C.F. Müller Verlag, pp. 579-591

Hancher, L. (1998), Cross-Subsidization and EC Law, Common Market Law Review, vol. 35, pp. $901-945$

Hancher, L., Ottervanger, T., Slot, P.J. (1999), E.C. State Aids, second edition, London: Sweet \& Maxwell

Happé, R. (1996), Drie beginselen van fiscale rechtsbescherming, Fiscale monografieën, nr. 77, Deventer: Kluwer

Heldeweg, M.A. (2000), Ongeschreven rechtsbeginselen en geïmpliceerde bevoegdheden als opmaat voor een autonoom bestuursrecht?, in: Koning, H., Crombag E.M.J. (eds.), De autonomie van het bestuursrecht, The Hague: Boom Juridische Uitgevers, pp. 11-55 Hilf, M., Schorkopf, F. (2000), WTO und EG: Rechtskonflikte vor den EuGH?, Europarecht, vol. 35 , no. 1, pp.74-91

Hinnekens, L. (2000), European Commission investigates compatibility of Belgian coordination centre tax legislation with European state aid rules, EC Tax Review, no. 4, pp. 249-251 
Hoenike, M. (1997), Rückfordering unzulässiger Beihilfen, Europäische Zeitschrift für Wirtschaftsrecht, no. 9, pp. $280 \mathrm{ff}$

Hufbauer, G.C., Gabyzon, C. (1996), Fundamental Tax Reform and Border Tax Adjustments, Washington D.C.: Institute for International Economics

Jackson, J.H. (1978), The Jurisprudence of International trade: The DISC Case in GATT, American Journal of International Law, vol. 72, pp. 747-781

Jackson, J.H. (1997), The World Trading System - Law and Policy of International Economic Relations, second edition, London: The MIT Press

Jackson, J.H. (1999), The WTO Dispute Settlement Understanding - Misunderstandings on the Nature of Legal Obligation, in: Cameron, J., Campbell, K. (eds.), Dispute Resolution in the World Trade Organisation, London: Cameron May

Jans, J.H., De Lange, R., Prechal, S., Widdershoven, R.J.G.M (1999), Inleiding tot het Europees bestuursrecht, Nijmegen: Ars Aequi Libri

Jestaedt, T., Ottervanger, T.R., Cutsem, J-P van (1999), Application of EC state aid law by the Member States Courts, Luxembourg: Office for Official Publications of the EC

Joris, T. (1994), Nationale steunmaatregelen en het Europees gemeenschapsrecht, Antwerpen: Maklu

Koenig, C., Sander, C. (2000), Die verbrauchervermittelte Unternehmensbegünstigung auf dem Prüfstand des EG-Beihilfenrechts, Europarecht, no. 5, pp. 743-767

Koning, H., Crombag, E.M.J. (2000), introduction to: Koning, H., Crombag E.M.J. (eds.), De autonomie van het bestuursrecht, The Hague: Boom Juridische Uitgevers, pp. 1-6

Koschyk, M.M. (1999), Steuervergünstigungen als Beihilfen nach Artikel 92 EG-Vertrag, Baden-Baden: Nomos Verlagsgesellschaft

Kuilwijk, K-J. (1996), The European Court of Justice and the GATT Dilemma: Public Interest versus Individual Rights, Beuningen: Nexed Editions Academic Publishers

Kuyper, P-J. (1995), The New WTO Dispute Settlement System: The Impact on the European Community, Journal of World Trade, vol. 64, pp. 49-71

Lehner, M., Scherer, T.B. (1995), Die Beseitigung der Doppelbesteuerung innerhalb der Gemeinschaft, in: Birk, D. (ed.), Handbuch des Europäischen Steuer- und Abgabenrechts, Herne/ Berlin: Verlag Neue Wirtschafts-Briefe

Lenaerts, K., Arts. D. (1999), Europees Procesrecht, second edition, Antwerpen: Maklu

Lopez-Mata, R. (2001), Income Taxation, International Competitiveness and the World Trade Organization Rules on Subsidies: Lessons to the U.S. and to the World from the FSC Dispute, The Tax Lawyer, vol. 54, pp. $577 \mathrm{ff}$.

Malherbe, J. (2000), Harmful Tax Competition and the Future of Financial Centres in the European Union, in: Kirchhof, P., Lehner, M., Raupach, A., Rodi, M. (eds.), Staaten und Steuern - Festschrift für Klaus Vogel zum 70. Geburtstag, Heidelberg: C.F. Müller Verlag, pp. 1125-1135

McDaniel, P.R., Surrey, S.S. (1985), International Aspects of Tax Expenditures: A Comparative Study, Deventer: Kluwer

McDaniel, P.R. (2000), The Impact of Trade Agreements on Tax Systems, in: Kirchhof, P., Lehner, M., Raupach, A., Rodi, M., (eds.), Staaten und Steuern - Festschrift für Klaus Vogel zum 70. Geburtstag, Heidelberg: C.F. Müller Verlag, pp. 1105-1115

McDaniel, P.R. (2001), The Pursuit of National Tax Policies in a Globalized Environment: Trade and Taxation, Brooklyn Journal of International Law, vol. 26., pp. 1621-1640

Mederer, W. (1999), Staatliche beihilfen, in: Von der Groeben, H., Thiesing, J., Ehlermann, C-D. (eds.), Kommentar zum EU-/EG-Vertrag, vol. 2/II, fifth edition, Baden-Baden: Nomos Verlags-gesellschaft 
Monnier, P. (2001), The Time to Comply with an Adverse WTO Ruling, Journal of World Trade, vol. 35, no. 5, pp. 825-845

Nicolaï, P. (1990), Beginselen van behoorlijk bestuur, Deventer: Kluwer

Nicolaides, P., Bilal, S. (1999), State Aid Rules: Do They Promote Efficiency?, in: Bilal, S., Nicolaides, P. (eds.), Understanding State Aid Policy in the European Community: Perspectives on Rules and Practice, Maastricht: European Institute of Public Administration / Kluwer Law International, pp. 29-46

Niessen, R.E.C.M. (1997), Instrumentalisme en het belastingrecht, Weekblad fiscaal recht, pp. 653-661

Nieuwenhuis, J.H. (1997), Vechten met de beer? De strijd om het legaliteitsbeginsel, RM Themis, no. 9, pp. 351-352.

Nijkamp, H. (2001), Uitfasering van "schadelijke" belastingmaatregelen start in 2002, Weekblad fiscaal recht, vol. 130, pp. 391-399

Palao, C. (2001), The Foreign-Income Exemption in Spain and the Canary Islands Special Zone, Bulletin for international fiscal documentation, February 2001, pp. 62-67

Rädler, A.J., Lausterer, M., Blumenberg, J. (1997), Tax abuse and EC Law, EC Tax Review, no. 2, pp. 86-101

Rodi, M. (2000), Die Subventionsrechtsordnung, Tübingen: Mohr Siebeck

Scheltema, M.W. (1997), Onverschuldigde betaling, Deventer: Kluwer

Scheltema, M.W. (1998), Onverschuldigde betaling in het publiekrecht, Nederlands Juristenblad, 1998, no. 21, pp. 943-950

Schön, W. (1999), Taxation and state aid law in the European Union, Common Market Law Review, vol. 36, 911-936

Schön, W. (2000), Tax competition in Europe - the legal perspective, EC Tax Review, no. 2, pp. $90-105$

Schwartz, G., Clements, B. (1999), Government Subsidies, Journal of Economic Surveys, vol. 13, no. 2, pp. 119-147

Senden, L.A.J., Hancher, L. (2000), De juridische werking van communautaire beleidsregels inzake mededinging en staatssteun, Nederlands tijdschrift voor Europees Recht, no. 4, pp. 96-104

Simplicean-Stroia, I. (1997), Study of the State Aid Policy in the European Community: The "Illegal" State Aid Problem, Journal of International Legal Studies, vol. 3, p.p. 87-123

Sinnaeve, A. (1997), Die Rückforderung gemeinschaftsrechtswidriger nationaler Beihilfen: Kollisionen im Spannungsverhältnis zwischen Gemeinschafts- und nationalem Recht, Berlin: Duncker \& Humblot

Sinnaeve, A., Slot, P.J. (1999), The new regulation on state aid procedures, Common Market Law Review, vol. 36, pp. 1154-1194

Stanbrook, C., Bentley, P. (1996), Dumping and Subsidies, third edition, London: Kluwer Law International

Stolba, M. (1999), Europäisierung staatlicher Beihilfen: Direkte und indirekte Kollisionen, Rückforderung - Staatshaftung, Frankfurt am Main: Peter Lang,

Sugin, L. (1999), Tax Expenditure Analysis and Constitutional Decisions, Hastings Law Journal, vol. 50, no. 3, pp. 407-474

Surrey, S.S. (1973), Pathways to Tax Reform: The Concept of Tax Expenditures, Cambridge, Massachusetts: Harvard University Press

Surrey, S.S., Sunley, E.M. Jr. (1976), General Report, in: Tax incentives as an instrument for achievement of governmental goals, Cahiers de droit fiscal international, volume LXIa, pp. 15-63 
Ten Berge J.B.J.M., Michiels, F.C.M.A. (2001), Besturen door de overheid, fourth edition, Deventer: W.E.J. Tjeenk Willink

Tipke, K. (1993), Die Steuerrechtsordnung, Köln: Verlag Dr. Otto Schmidt

Tomuschat, C. (1997), Abkommen der Gemeinschaft, in: Von der Groeben, H., Thiesing, J., Ehlermann, C-D. (eds.), Kommentar zum EU-/EG-Vertrag, vol. 5, fifth edition, BadenBaden: Nomos Verlagsgesellschaft

Van der Burg / Van Buuren / Van der Veen (1997), AB Klassiek, third edition, Deventer: W.E.J. Tjeenk Willink, pp. 238-244

Van der Burg, F.H. (1998), Europees gemeenschapsrecht in de Nederlandse rechtsorde, Deventer: W.E.J. Tjeenk Willink,

Vanistendael, F. (2000), Fiscal support measures and harmful tax competition, EC Tax Review, no. 3, 152-161.

Vanistendael, F. (2001), De fiscale Janus met het dubbele voorhoofd, soevereiniteit en schadelijke belastingconcurrentie, Tijdschrift Fiscaal Ondernemingsrecht, April, pp. 63-77

Van Maanen, G.E., De Lange, R. (2000), Onrechtmatige overheidsdaad, third edition, Deventer: W.E.J. Tjeenk Willink

Van Suilen, A.J.H. (2001), Risicoreserve, PhD-thesis edition, Deventer: Kluwer

Van Wijk, H.D., Konijnenbelt, W., Van Male, R.M. (1999), Hoofdstukken van bestuursrecht, eleventh edition, The Hague: Elsevier bedrijfsinformatie B.V.

Verheij, N. (1997), Vertrouwen op de overheid, in: Vertrouwensbeginsel en rechtszekerheid in Nederland, Preadviezen voor de Vereniging voor de Vergelijkende studie van het recht van België en Nederland, Deventer: W.E.J. Tjeenk Willink

Vermeend, W.A. (1996), Instrumentalisering van het belastingrecht, Weekblad fiscaal recht, no. 6186 , pp. $209-213$

Vermeend, W.A. (1998), Tax policy in Europe, EC Tax Review, no. 3, pp. 151-159

Visser, K-J. (2000a), Fiscale maatregelen en communautaire steunmaatregelen: materieel recht, Weekblad fiscaal recht, no. 6389, pp. 841-850

Visser, K-J. (2000b), Fiscale maatregelen en communautaire steunmaatregelen: formele procedures en terugvordering, Weekblad fiscaal recht, no. 6390, pp. 863-871

Vogel, K. (1977), Die Abschichtung von Rechtsfolgen im Steuerrecht. Lastenausteilungs-, Lenkungs- und Vereinfachungsnormen und die ihnen zuzurechnenden Steuerfolgen: ein Beitrag zur Methodenlehre des Steuerrechts, Steuer und Wirtschaft, vol. 54, no. 2, pp. 97-121

Waer, P., Vermulst, E. (1999), EC Anti-Subsidy Law and Practice After the Uruguay Round: A Wolf in Sheep's Clothing?, Journal of World Trade, vol. 33, no. 3, pp. 19-43

Wagner, A. (1890), The Basic Principles of Taxation, in: Finanzwissenschaft, part II, second revised edition, Leipzig, pp. 207-208 and 299-305, as translated and reprinted in: Musgrave, R.A., Peacock, A.T. (eds.) (1958), Classics in the theory of public finance, London: Macmillan \& Co.

Wattel, P.J. (1996), Beggar thy neighbour, Weekblad fiscaal recht, no. 6225, pp. 1854-1858

Weber, A., Moos, M. (1999), Rechtswirkungen von WTO-Streitbeilegungs-entscheidungen im Gemeinschaftsrecht, Europäische Zeitschrift für Wirtschaftsrecht, no. 8, pp. 229-236

Weerth, J. de (2001), Rückwirkende Absenkung von steurrrechtlichten Beihilfen nach Feststelling ihrer Unvereinbarkeit mit EG-Recht durch die Kommission zulässig?, IStR, no. 5, pp. 158-160

Westin, R.A. (1997), Environmental Tax Initiatives and Multilateral Trade Agreements: Dangerous Collisions, Cambridge, Massachusetts: Kluwer Law International

Westin, R.A., Vasek, S. (2001), The Extraterritorial Income Exclusion: Where Do Matters Stand Following the WTO Panel Report?, Tax Notes International, vol. 23, pp. 337-369 
Widdershoven R.J.G.M. (1994), De uitvoering van het gemeenschapsrecht in de lidstaten en de toepassing van het vertrouwensbeginsel, Nederlands Tijdschrift voor Bestuursrecht, no. 1, pp. 1-13

Widdershoven, R.J.G.M. (2000), Nationaal bestuursrecht in de Europese rechtsorde, in: Koning, H., Crombag E.M.J. (eds.), De autonomie van het bestuursrecht, The Hague: Boom Juridische Uitgevers, pp. 203-224

Wishlade, F. (1996), Subsidies and State Aids: The Definition of Acceptable Measures under the European Union and World Trade Organisation Rules, Regional and Industrial Research Paper, no. 21, Glasgow: European Policies Research Centre

Wishlade, F. (1997), When are Tax Advantages State Aids and When are They General Measures, Regional and Industrial Research Paper, no. 20, Glasgow: European Policies Research Centre

Wouters, J. (2001), Europese regels inzake overheidssteun en directe belastingen: enkele kanttekeningen, Tijdschrift Fiscaal Ondernemingsrecht, no. 54, pp. 131-140

The author's previous publications on this subject:

Luja, R.H.C. (1999a), WTO Agreements versus the EC Fiscal Aid Regime: Impact on Direct Taxation, Intertax, vol. 27, no. 6-7, pp. 207-225

Luja, R.H.C. (1999b), Een gerechtvaardigd vertrouwen in belastingfaciliteiten?, Weekblad fiscaal recht, vol. 128 , no. 6351, pp. 1045-1055

Luja, R.H.C. (1999c), Onwettige fiscale steunverlening: schadevergoeding en rechtsonzekerheid, Weekblad fiscaal recht, vol. 128, no. 6358, pp. 1337-1342

Luja, R.H.C. (2000a), Anti-tax-avoidance Rules and Fiscal Trade Incentives, Intertax, vol. 28, no. 6-7, pp. $226-240$

Luja, R.H.C. (2000b), Tax entities and fiscal state aids, EC Tax Review, vol. 9, no. 3, pp. 190 191

Luja, R.H.C. (2000c), De implementatie van beschikkingen tot terugvordering van staatssteun in het Nederlandse bestuursrecht, Nederlands tijdschrift voor Europees recht, vol. 6, no. 10, pp. 243-255

Luja, R.H.C. (2001a), Fiscale staatssteun: recente ontwikkelingen, Weekblad fiscaal recht, vol. 130 , no. 6444 , pp. $1055-1059$

Luja, R.H.C. (2001b), Terugvordering van fiscale staatssteun: Navordering vanuit Europees perspectief, Tijdschrift voor Formeel Belastingrecht, no. 9, pp. 4-9

Luja, R.H.C. (2002), Fiscale staatssteun: recente ontwikkelingen (2), Weekblad fiscaal recht, vol. 131, pp. 143-148

Chapters II, VI and VII contain parts of a translated and amended version of the author's Dutch contribution to the Nederlands tijdschrift voor Europees recht (2000c), published by Elsevier Bedrijfsinformatie, The Hague. Chapter VII contains parts of a translated and amended version of a text previously published in Dutch in the Tijdschrift voor Formeel Belastingrecht (2001b), published by Koninklijke Vermande BV, The Hague. 


\section{KEYWORDS}

Accelerated depreciation

Actionable subsidies (see SCM Agreement)

Administration of subsidies

Association agreement

Avoidance of double taxation

Autonomy (see Regions)

Bankruptcy (see Insolvency)

Benefit (see State aid / SCM Agreement)

CFC legislation (see Harmful tax competition)

Code of conduct (see Harmful tax competition)

Community loyalty

Compatibility of EC state aids

- Conservation of heritage

- Consumers (aid to individual ...)

- Cultural promotion

- De minimis aids

- Economic disturbances

- Effet utile

- Environmental protection

- Incompatibility

- Natural disasters

- Project of European interest

- Regional economic development

- Rescuing and restructuring

- Risk capital

- Sensitive sectors

- Small and medium sized enterprises

- Social character

- Training aid

- Useful effect (see Effet utile, supra)

Competitors (of aid recipients)

Consumer benefits (see State aid definition)

\section{II.1.2.4, IV.7.4}

I.2.3.2, I.2.4.3

II.1.1 (footnote), II.2.3.2 (footnote),

II.4.2.1 (footnote), V.3 (footnote)

III.2.3, IV.3.2.1, IV.5.2.2, IV.5.2.5
III.2.2, VI.2

II. 2.1, V.5.4

II.2.3.6

II.2.2 (footnote)

II. 2.3 .6

II.3.2, V.5.2, VI.4.3, VIII.1, VIII.3

II. 2.3.4

III.2.2, VIII.1, VIII.3

II.3.5

II.1

II. 2.2

II. 2.3 .3

II. 2.3.2, II. 2.3.5, II.3.3, V.5.3

II. 3.6

II.3.7

II. 3.1

II.1.5.5 (footnote), II.3.4

II. 2.2

II.3.4

II.4.3.2, V.4.4.2, VI.6, VIII.I 
Credits (see Tax credits)

Cross-border effects

Countervailing duties (see SCM agreement)

Damages (see Recovery of state aids)

Deductions (see Tax deductions)

Deferral (see Tax deferral)

De minimis (see Compatibility of aids)

DISC (see Domestic International Sales Corporation)

Discretion

II.1.5.3, IV.7.4

Distortion of competition (see State aid)

Domestic International Sales Corporation

IV.5.1

Double taxation (see Avoidance of ...)

Effet utile (see Compatibility of EC state aids)

Efficiency

Environmental investments

Equity

I.2.1, II.3.5

I.2.3.1

Europe Agreements (see Association Agreement)

Exemptions (see Tax exemptions)

Expenditure (see Tax expenditure)

Export

Extraterritorial income exclusion

Fines

Fiscal sovereignty (see Sovereignty)

Foreign sales corporation

Formal investigation (see State aid procedure)

Free movement provisions

Free rider

FSC (see Foreign sales corporation)

General economic interest

II.1.5.9, IV.3.2.1

IV.5.2.4, IV.5.2.5, IV.5.2.6

VI.5

I.2.6, IV.5.2

III.3

I.2.1

II.1.2.9

III.1, VIII.2.2

III.1.3, III.2, VIII.2.2, VIII.3

III. 2.4

III.1, VIII.2.2, VIII.3

III.1.4

III. 2.2

III.1.5

II.1.2.3

II.3.3

IV.7.2

II.1.2.7

I.2.1, I.2.6

V.2, V.4.1

II.1.5.2 
National courts

Newly established companies

Neutrality

Non-actionable subsidies (see SCM Agreement)

Preliminary investigation (see State aid procedure)

Prohibited subsidies (see SCM Agreement)

Recovery of state aid (also see SCM Agreement)

- Absolute impossibility

- Ad hoc regulations

- Administrative difficulties

- Awareness

- Constitution

- Damages

- Effectiveness

- Equivalence

- Exceptional circumstances

- Expediency

- Financial difficulties

- Foreseeability

- Interest

- Legal basis

- Legal certainty

- Legitimate expectations

- Net benefit

- Netherlands fiscal framework

- Prevention of ....

- Proportionality

- Tax deductible expense

- Time limits

Regions

- Autonomy

- Economic development

Remittance of taxes

Rent extraction (see Cross-border effects)

Reserves (see Tax deferral)

Revenue collection

Right of establishment

Risk (as a decision factor)

SCM Agreement

- Actionable subsidies

- Adverse effects

- Appellate Body (see Procedure, infra)

- Appropriate forum

- Arbitration (see Procedure, infra)

- Benefit

- Cost to government
II.1.5.10, VI.3.4, VI.6, VII.3.1.2,

VII.3.4.1, VII.3.5, VIII.1

II.1.5.12

I.2.3.1

II.4.2.6, V.5.6, VI.1, VIII.1, VIII.2.2

VI. 3

VII.3.4.2

VI.3.3

II.1.3.2, VI.4.1, VII.2.2.3, VIII.1

VI.2, VI.4.1 (footnote)

VI.7, VII.2.2.2 (footnote)

VI.2, VII.3.1.2, VIII.2.2

VI.2, VII.3.1.2, VIII.2.2

VI.3.1, VIII.1, VIII.3

VI.4.3

VI. 3.2

VI.4.2, VII. 2.2 .3

II.4.2.6, VI.1, VI.6, VII.3.3, VII.3.4.1,

VII.3.5, VIII.3

VI.1

VII.2.1

VI.4, VII.2.2, VIII.1

II.1.2.7, III.1.3, VI.7

VII.2, VII.3, VIII.2.2, VIII.3

VI.6, VII.3.5

VI.1

VI.7

II.4.2.6, VI.4.3, VII.3.1.3, VII.3.4.1

II.1.5.8, IV.3.3.2

II. 2.3 .2 , II.2.3.5, II. 3.3

II.1.2.5

I.2.2, I.2.3.1

II.1.3.4 (footnote), III.3

I.2.4.4

IV. 3.3

IV.3.3.3

IV.5.2.3

IV. 2

IV.2 
SCM Agreement [continued]

- Countermeasures

IV.3.2.3, IV.5.2.7

- Counter-subsidies

IV. 8

- Countervailing duties

- Developing countries

IV.1, IV.6, IV.7

IV.3.2.5

- Direct effect (in the EC)

V.4.4.2, V.4.4.3, VIII.3

- Dispute Settlement Body (see Procedure, infra)

- EC State Aids (disparities)

V.5, VIII. 2.1

- EC / EU Member States

V.3, V.4, V.5

- Export contingency

IV.3.2.1, IV.5.1, IV.5.2

- Financial contribution

IV.2, IV.7.1

- Import substitution

IV.3.2.2

IV.7.1

- Indirect subsidies

IV.3.3.3

- Injury (material)

IV. 4.2

- Non-actionable subsidies

IV.3.1

- (21.5) panel (see Procedure, infra)

- Procedure

IV.3.2.3, IV.3.2.4, IV.3.3.4, IV.6.2,

IV.7, IV.5.2, V.5.1

- Prohibited subsidies

- Recovery (see Withdrawal, infra)

IV.3.2

- Regional autonomy (see Regions)

- Serious prejudice

IV.3.3.3

- Services

- Specificity

- Subsidy definition

IV.9, VIII.2.1, Annex

IV.3.3.2; IV.7.5

IV. 2

IV.5.2.2

- Territoriality principle

IV.4.1, IV.4.2, IV.5.2, V.5.6, VIII.2.1, VIII.3

\section{Sectoral taxation}

Selectivity (see State aid / SCM Agreement)

Social welfare

II.1.5.6, II.1.5.7

Specificity (see State aid/SCM Agreement)

State aid definition

II.1

- Benefit

II.1.2

- Distortion of competition

II.1.4

- Compatibility (see Compatibility of ..., supra)

- Consumer-transferred benefits

II. 2.2

- Economic activity

- Foreign tax regimes

II.1.2.8

- General measures

II.1.5.2

- Incompatible

II.1.1

- Indirect aids

- Intention to grant aid

II.1.3.3, II.2.2, II.3.2.2, VI.3.3

II.1.3.2

III.1.3.1

- Objective concept

II.1.3.4

- Over-all tax burden

V.5, VIII. 2.1

- SCM agreement (disparities)

II.1.5 
State aid definition [continued]

- Specificity

II.1.5

- State resources

II.1.3

State aid procedure

- Annulment

II. 4

- Conditional opt-in

II. 4.3 , VI. 4.4

- Council intervention

VI.6, VII.3.5, VIII.3

II. 2.4

- Existing aid

II.4.2.2, II.4.3.3, VI.4.3

II.4.2.5, II.4.2.6

VI.2

- National procedure

II. 4.2 .2 , II.4.3.3, VI.4.3, VIII.3

- New aid

II.4.1, II.4.2.2, II.4.2.3, VI.6, VII.3.5, VIII.2.2, VIII.3

- Preliminary investigation

II.4.2.4

- Recovery (see Recovery of state aid)

- SCM agreement

V.5.1, V.5.6

- Standstill / suspension

- Unlawful aid

II.4.1, II.4.2.6, VI.1, VII.3.5, VIII.2.2, VIII.3

II.4.2.2, II.4.2.6

State resources (see State aid)

Subsidies (see State aid /SCM Agreement)

Subsidisation

Sunset-clause

Tax advisor

Tax credits

Tax deductions

Tax deferral

Tax exemption

Tax expenditure

Tax incentives (in general)

- Confidentiality

- Visibility

I.2, VIII.1, VIII.3

I.2.5, VIII.1

VII.2.2.3, VIII.1

I. 2.2 , III. 2.3

I.2.2, II.1.2.7, IV.7.2

I.2.2, II.1.2.3, II.4.2.6, IV.7.3

I.2.2, II.1.2.2, III.2.3, IV.7.2

I.2.2, I.2.4.5, II.1.2.1, VIII.1, VIII.3

I.2.2, VIII.1, VIII.3

I.2.4.2

I.2.4.1

Tax penalty

II.1.2.6

Tonnage tax

II.3.1

Transparency

I.2.3.2, VIII. 2.2

Transfer pricing

Unlawful aids (see State aid procedure)

II.1.2.2, II.1.5.4, III.1.3.2, III.2.2

(footnote), IV.3.2.1, IV.5.2, IV.5.3 
Keywords 


\section{CURRICULUM VITAE}

Raymond H.C. Luja was born on June 5th, 1976 in Heerlen, The Netherlands. He obtained his pre-university degree cum laude from the Atheneum College Sittard in June 1994. He got his Master's degree in Fiscal Economics from Maastricht University in August 1998. He received his Master's degree in Law from the Open University of the Netherlands in January 2001.

He has been a researcher at the Department of Tax Law at Maastricht University from October 1998 till June 2002. As from July 2002 he is a lecturer at that same Department. Luja finished his PhD-thesis there in October 2002. His main field of work concerns corporate taxation, entrepreneurial income taxation and European taxation. He joined the Committee on European taxation issues at Loyens \& Loeff Amsterdam in July 2001. He is also a member of the Ius Commune Research School. 
A book series devoted to the common foundations of the European legal systems. The lus Commune Europaeum series includes comparative legal studies as well as studies on the effect of treaties within national legal systems. All areas of the law are covered. The books are published in various European languages under the auspices of METRO, the Institute for Transnational Legal Research at Maastricht University.

This book provides for a unique combination. It enables readers with a tax background to place taxation in the perspective of trade subsidy regulation. It will make this topic more accessible to them by focussing on the main material and procedural provisions of both the EC and the WTO Subsidy regimes from a fiscal perspective. For experts in the field of EC state aid regulation and/or the WTO Subsidies Agreement this thesis will prove to be of value for getting an insight in certain tax aspects of both regimes since it will concentrate on some of the more controversial and theoretical issues. 